\author{
UNIVERSIDADE DE SÃO PAULO \\ FACULDADE DE FILOSOFIA, LETRAS E CIÊNCIAS HUMANAS \\ DEPARTAMENTO DE HISTÓRIA \\ PROGRAMA DE PÓS-GRADUAÇÃO EM HISTÓRIA SOCIAL
}

\title{
OS CRUZADOS DA ORDEM JURÍDICA A atuação da Ordem dos Advogados do Brasil (OAB), 1945-1964
}

Marco Aurélio Vannucchi Leme de Mattos

Tese apresentada ao Programa de Pós-Graduação em História Social do Departamento de História da Faculdade de Filosofia, Letras e Ciências Humanas da Universidade de São Paulo para a obtenção do título de doutor em História

Orientadora: Profa. Dra. Maria Aparecida de Aquino

Versão corrigida

São Paulo

2011 
Para Regiane, com quem compartilho a vida e os sonhos 


\section{AGRADECIMENTOS}

A professora Maria Aparecida de Aquino deu-me respaldo em todos os momentos em que precisei e autonomia para realizar a pesquisa. Devo a ela, que foi minha orientadora desde os tempos da graduação, um papel central na minha formação como historiador.

A professora Maria Victoria Benevides acompanhou todo o desenvolvimento da tese e, em várias ocasiões, debateu comigo questões abordadas na pesquisa. Beneficieime não apenas de seu grande conhecimento sobre o período democrático, mas também de sua rara generosidade intelectual e humana.

O professor Sergio Adorno participou tanto da minha banca de qualificação quanto do exame final. Em ambas as ocasiões fez importantes comentários e sugestões que procurei incorporar à tese.

O professor Luiz Felipe de Alencastro recebeu-me com muita atenção na Universidade Paris IV (Sorbonne) na condição de orientador do meu doutoradosanduíche. Acompanhei com proveito o seu seminário de pesquisa e tive a oportunidade de apresentar, a seu convite, uma síntese do meu trabalho naquela universidade.

As professoras Angela Maria de Castro Gomes e Denise Rollemberg, além de terem contribuído com observações e comentários ao longo do desenvolvimento do trabalho, participaram da banca de defesa da tese.

Alguns amigos leram o projeto inicial e trechos da tese, ou, ainda, fizeram sugestões e indicaram bibliografia. A eles a minha gratidão: André Mota, Andréa Slemian, Janes Jorge, Mariana Joffily, Paulo Fontes e Walter Cruz Swensson Júnior.

Também tive a sorte de contar com a interlocução de alguns pesquisadores, aos quais agradeço pela disposição em debater aspectos do meu trabalho: Andrei Koerner, Fernando Lattman-Weltman, Maria Letícia Correa e Marly Silva da Motta.

Minha mãe, Miriam, e meus irmãos Ana Beatriz e Paulo Augusto me ajudaram incontáveis vezes, especialmente no período em que morei na França. A eles a minha gratidão e o meu carinho. 
Letícia Nunes de Moraes fez uma revisão paciente e minuciosa do texto da tese. Com muita competência, ela ajudou a tornar a tarefa do leitor deste trabalho menos penosa.

Fui muito bem atendido em todas as bibliotecas e arquivos em que pesquisei. Quero, por isto, expressar o meu reconhecimento aos funcionários destas instituições, que, em condições por vezes adversas, desempenham uma atividade pública da maior relevância.

A FAPESP concedeu-me uma bolsa de doutorado, sem a qual este trabalho não teria sido realizado. Quero também manifestar o meu reconhecimento ao parecerista anônimo da FAPESP, cujas observações e indicações - precisas e pertinentes - foram sempre um incentivo para prosseguir a investigação.

Regiane Augusto de Mattos, a quem este trabalho é dedicado, apoiou-me incondicionalmente. Graças a ela as asperezas da pesquisa tornaram-se suportáveis. Também devo a ela uma leitura atenta da tese. 


\section{RESUMO}

A presente tese examina a atuação da Ordem dos Advogados do Brasil (OAB), por meio de sua instância diretiva máxima, o Conselho Federal, entre 1945 e 1964. A ação pública do órgão, neste período, pode ser decomposta em três fases. Em meados da década de 1940, o Conselho Federal engajou-se profundamente na oposição ao Estado Novo. Na década de 1950, forçado pelas transformações que atingiam a advocacia, o organismo centrou-se numa agenda eminentemente corporativa. Finalmente, no início da década de 1960, o Conselho retomou uma postura fortemente politizada para combater o governo Goulart. Destacam-se, no trabalho, quatro eixos temáticos: 1.) o perfil da elite dirigente da $\mathrm{OAB}$; 2.) a relação da Ordem dos Advogados com o Estado; 3.) a relação da Ordem com a sociedade civil; 4.) a relação da Ordem com a categoria profissional que representava.

Palavras-chave: advogados; Estado; sociedade civil; democracia; liberalismo. 


\begin{abstract}
The present thesis examines the performance of OAB (Ordem dos Advogados do Brasil), through its highest authority, Federal Council, between 1945 and 1964. The public action of the organ, in this period, can be decomposed in three phases. In the middle of the 1940s, Federal Council was deeply engaged in the opposition to the New State. In the 1950s, forced by the changes that reached the advocacy, the organism was centered in an eminently corporate agenda. Finally, in the beginning of 1960s, the Council recovered a strongly politicized posture to fight Goulart administration. Four themes are accentuated in the work: 1.) the profile of $\mathrm{OAB}$ elite; 2.) the relationship between $\mathrm{OAB}$ and the State; 3.) its relationship with the civil society; 4.) its relationship with the professional category that it represented.
\end{abstract}

Keywords: lawyers; the State; civil society; democracy; liberalism. 


\section{SUMÁRIO}

Introdução

\section{Capítulo I: Estado Novo e governo Dutra}

1.) A frente oposicionista 45

2.) O engajamento do Conselho Federal no combate ao Estado 46 Novo

3.) A ação oposicionista do Conselho Federal em 1945

4.) O manifesto de apoio dos advogados cariocas a Eduardo 63 Gomes

5.) O Conselho Federal em busca de aliados na sociedade civil e 72 no aparato estatal

6.) O Conselho Federal frente ao governo Dutra 75

Capítulo II: A pauta corporativa da década de 1950

1.) A nova agenda 78

2.) $\mathrm{O}$ novo estatuto da $\mathrm{OAB} \quad 87$

3.) A previdência social dos advogados 93

4.) Estágio profissional e Exame da Ordem 103

Capítulo III: Governo Goulart e o golpe civil-militar de 1964

1.) A renúncia de Jânio Quadros 111

2.) A tomada de posição contra Goulart 113

3.) Reforma agrária 118

4.) O episódio Hélio Fernandes 122

5.) A Revolta dos Sargentos 124

6.) Nas vésperas do golpe 125

$\begin{array}{ll}\text { 7.) Ditadura Militar } & 127\end{array}$ 


\section{Capítulo IV: Perfil institucional da OAB}

1.) Dinâmica e composição do Conselho Federal 137

2.) A missão da $\mathrm{OAB}$

\section{Capítulo V: Perfil dos conselheiros federais}

1.) Os bâtonniers do período democrático 155

2.) Perfil dos conselheiros federais 161

a.) Estado natal e local de formação 162

b.) Atividades profissionais 163

$\begin{array}{ll}\text { c.) Associativismo } & 169\end{array}$

d.) Direção do Estado e participação política 171

e.) Vínculos partidários 177

f.) Vínculos de classe 183

Capítulo VI: A relação do Conselho Federal com o Estado

1.) O Conselho Federal contra o aparato policial 186

2.) A mobilização pela autonomia da $\mathrm{OAB}$

3.) A relação com o Congresso Nacional 199

4.) A relação com o governo 203

Capítulo VII: A relação do Conselho Federal com a categoria profissional

1.) A adesão dos advogados às posições do Conselho Federal 211

2.) A incorporação da função sindical 222

3.) As Conferências Nacionais da OAB 230

$\begin{array}{ll}\text { Conclusão } & 235\end{array}$ 
Fontes documentais e bibliografia

Apêndices

255 


\section{LISTA DE TABELAS}

Tabela 1: Ensino de Direito no Brasil (1907-1958)

Tabela 2: Número de advogados no Brasil (1933-1970) 30

Tabela 3: Número de bacharéis em Direito no Brasil (1950- 31 1970)

Tabela 4: Renovação na composição do Conselho Federal 138 (1946-1964)

Tabela 5: Permanência dos conselheiros no Conselho Federal da OAB (1945-1964)

Tabela 6: Exercício de cargos no Executivo pelos conselheiros federais da OAB no período democrático 
"O Conselho Federal da Ordem dos Advogados do Brasil, que tem inscrito dentre os seus mais altos objetivos, o de lutar em defesa dos princípios fundamentais da ordem jurídica, não poderia permanecer indiferente à sua responsabilidade, no momento em que a preservação das leis e do direito corresponde à própria conservação da paz pública” (Ata do Conselho Federal da OAB, 18/09/1945).

“(...) considerando que, dentro de suas [do Conselho Federal da $\mathrm{OAB}$ ] finalidades estatutárias, estão na sua competência todas as medidas que forem necessárias à defesa das instituições e da liberdade profissional (...) Resolve o Conselho Federal (...) reafirmar (...) o seu repúdio a qualquer solução extremista, da esquerda ou da direita, a sua fé inabalável na democracia representativa, nas liberdades democráticas e na intangibilidade dos órgãos que representam a vontade popular devidamente constituídos." (Ata do Conselho Federal da OAB, 09/08/1962). 


\section{INTRODUÇÃO}

Ao ampliar, no âmbito da tradição marxista, o conceito de Estado, Antonio Gramsci demonstrou que a dominação de classe não se sustenta apenas na coerção exercida pelo aparato estatal stricto sensu (denominado por ele sociedade política), mas repousa, complementarmente, na ação dos aparelhos privados de hegemonia, inscritos na esfera da sociedade civil e devotados à obtenção do consenso. Numa passagem dos Cadernos do cárcere, Gramsci resume sua proposição pela fórmula "Estado = sociedade política + sociedade civil, isto é, hegemonia couraçada de coerção".

$\mathrm{O}$ intelectual italiano distingue dois tipos de formações sociais com base na relação estabelecida entre o Estado e a sociedade civil. Nas formações ocidentais há um equilíbrio entre as duas esferas, ao passo que nas formações orientais a sociedade civil é frágil perante o Estado:

"No Oriente, o Estado era tudo, a sociedade civil era primitiva e gelatinosa; no Ocidente, havia entre o Estado e a sociedade civil uma justa relação e, ao oscilar o Estado, podia-se imediatamente reconhecer uma robusta estrutura da sociedade civil. O Estado era apenas uma trincheira avançada, por trás da qual se situava uma robusta cadeia de fortalezas e casamatas (...) ".2

No Brasil, o desmoronamento do Estado Novo incentivou, a despeito da persistência da força do Estado, o processo de "ocidentalização". Assim, a sociedade civil, beneficiando-se da vigência de um regime democrático, conheceu um importante florescimento. Formada por partidos políticos, sindicatos operários, entidades patronais, organizações de trabalhadores rurais, igrejas, emissoras de rádio e televisão e jornais, além de associações profissionais, a sociedade civil brasileira, a partir de 1945, tornouse mais complexa e comportou interesses sociais divergentes.

\footnotetext{
${ }^{1}$ GRAMSCI, Antonio. Cadernos do cárcere. Maquiavel. Notas sobre o Estado e a política. Rio de Janeiro: Civilização Brasileira, 2000, v. 3, p. 244.

${ }^{2}$ Ibidem, p. 262.
} 
A motivação fundamental deste trabalho, ao tratar da atuação da Ordem dos Advogados do Brasil (OAB), por meio de seu órgão de cúpula, o Conselho Federal, é a de contribuir para a compreensão das relações estabelecidas entre o Estado e a sociedade civil no período democrático, cronologicamente delimitado entre os anos 1945 e 1964. Criada em 1930, sob os auspícios do Estado, a Ordem dos Advogados, por obra dos bacharéis que a comandavam, iniciou, em meados da década de 1940, um processo de autonomização que, mais tarde, garantiria à entidade uma posição destacada na sociedade civil.

Como procurarei demonstrar ao longo do trabalho, a OAB, ao integrar o Estado ampliado, constituía-se numa agência de hegemonia dedicada à realização da democracia liberal. Levi Carneiro, no momento em que se tornou o primeiro presidente do Conselho Federal, em 1933, reconheceu expressamente tal projeto:

"Constituímos, podemos constituir em todo o país uma elite capaz de influir, pelo exemplo e pela ação direta, na realização da democracia liberal. E, principalmente, capaz de formar, através de todo o País, um desses vínculos morais preciosíssimos que garantem as nacionalidades duradouras. "3

A OAB buscava conquistar adesão ao projeto democrático-liberal dirigindo-se a um público amplo por meio de moções, grandes eventos e declarações à imprensa. Mas também o fazia ao disseminar entre os advogados os seus valores profissionais.

As principais fontes documentais empregadas neste trabalho foram as atas das reuniões do Conselho Federal da OAB. O órgão reunia-se semanalmente, nove meses ao ano, entre abril e dezembro. Todas as questões centrais envolvendo a postura do Conselho frente à política nacional, bem como as temáticas relacionadas à vida interna da $\mathrm{OAB}$ e da categoria profissional estão documentadas nas atas. Consultei, igualmente, os boletins editados pelo Conselho Federal e os anais das conferências nacionais realizadas pela Ordem dos Advogados nos anos de 1958 e 1960.

Examinei também os dois estatutos da $\mathrm{OAB}$ vigentes no período democrático, o de 1933 e o de 1963. Eles definiam a organização da entidade em nível nacional,

\footnotetext{
3 Apud VENÂNCIO FILHO, Alberto. Notícia histórica da OAB, 1930-1980. São Paulo: Conselho Federal da OAB, 1982, p. 44.
} 
regional e local, estabeleciam os parâmetros para o exercício da advocacia, assim como previam os mecanismos decisórios e eleitorais da Ordem. Outras fontes consultadas foram os jornais editados no Rio de Janeiro, sobretudo o Correio da Manhã, o Diário de Notícias e O Jornal. As matérias selecionadas para análise abrangem os momentos de intervenção pública mais marcantes do Conselho Federal, como a democratização de 1945, as conferências nacionais da OAB e o governo Goulart. A relevância particular destas fontes reside no fato de que proporcionam um olhar externo sobre a atuação da entidade, além de fornecer elementos para a compreensão da repercussão alcançada pelas suas ações junto à categoria profissional, mas também na vida nacional. Finalmente, realizei uma ampla pesquisa em repertórios biográficos que me permitiu perfilar os integrantes da direção da Ordem dos Advogados.

É preciso, agora, explanar o plano da tese. Ainda nesta Introdução, estão presentes alguns elementos de uma sociologia e de uma história dos advogados no Brasil, que inclui um recuo temporal com ênfase na análise dos períodos do Império e da Primeira República, pois a bibliografia disponível sobre a morfologia da profissão e a vida política e associativa dos bacharéis em Direito concentram-se nestes períodos. Todavia, este retrospecto cumpre um objetivo preciso: o de apontar importantes continuidades, sobretudo entre os juristas-políticos do século XIX e os do século XX.

A ação pública do Conselho Federal, no período democrático, pode ser decomposta em três fases, estudadas nos três capítulos iniciais. O Capítulo 1 analisa a participação do organismo na oposição ao Estado Novo. O Capítulo 2 trata das démarches da década de 1950 em torno dos interesses específicos dos advogados, ao passo que o Capítulo 3 examina o retorno da $\mathrm{OAB}$ ao cenário político durante o governo Goulart. Dediquei o Capítulo 4 ao estudo da organização interna do Conselho Federal e, igualmente, de suas atribuições políticas e corporativas. No Capítulo $V$ tracei um perfi dos bacharéis que integraram o Conselho durante o período democrático. No Capítulo VI, estudei a relação do Conselho Federal com o Estado e, no Capítulo VII, a sua relação com o conjunto dos advogados. Na Conclusão, sintetizei os principais pontos de minha análise e apontei alguns elementos da trajetória da OAB durante a 
ditadura militar - ao final da qual, a entidade consolidaria sua autonomização em relação ao Estado e ocuparia um papel destacado na redemocratização do país.

\section{Os juristas-políticos na direção do Estado}

A criação dos cursos jurídicos no país, em 1827, respondeu, em boa medida, à necessidade de se formar os quadros de direção do Estado nacional emergente. ${ }^{4}$ Os primeiros estatutos a regularem o funcionamento das escolas de Direito, elaborados pelo visconde de Cachoeira, admitiam tal propósito, ao expressar que elas deviam se dedicar, para além da preparação dos futuros juristas e advogados, à formação de deputados, senadores, diplomatas e altos funcionários do Estado. ${ }^{5}$ Ao descrever a vida estudantil de seu pai em Olinda, no início da década de 1830, Joaquim Nabuco anotou: “já então as faculdades de Direito eram ante-salas da Câmara. "6 Esta marca de nascença jamais abandonou os bacharéis, eternamente divididos - isto é válido, ao menos, para a sua elite - entre as lides jurídicas e os negócios do Estado, entre os escritórios de advocacia e os gabinetes de governo.

No Império, o aparato estatal esteve sob domínio dos bacharéis em Direito. Eles exerceram as principais funções no Judiciário, no Legislativo e no Executivo (como delegados de polícia, secretários e presidentes de província, ministros e conselheiros de Estado). Ao analisar a lista dos alunos que se diplomaram pela Faculdade de Direito de São Paulo entre 1828 e 1883, Sergio Adorno identificou 73 acadêmicos que se destacaram na vida pública nacional. ${ }^{7}$ E José Murilo de Carvalho calculou em 72,5\% os ministros do Império que eram bacharéis em Direito. ${ }^{8}$

\footnotetext{
${ }^{4}$ ADORNO, Sergio. Os aprendizes do poder. Rio de Janeiro: Paz e Terra, 1988, p. 235-236; VENÂNCIO FILHO, Alberto. Das arcadas ao bacharelismo. São Paulo: Perspectiva, 1977, p. 273.

${ }^{5}$ CARVALHO, José Murilo de. A construção da ordem:a elite política imperial. Teatro de sombras:a política imperial. Rio de Janeiro: Civilização Brasileira, 2003, p. 76.

${ }^{6}$ NABUCO, Joaquim. Um estadista do Império. São Paulo: Instituto Progresso Editorial, 1949, v.1, p. 19.

${ }^{7}$ ADORNO, Sergio, op. cit., p. 134-135. Ver, também, MICELI, Sergio. Intelectuais e classe dirigente no Brasil (1920-45). In: MICELI, Sergio. Intelectuais à brasileira. São Paulo: Companhia das Letras, 2001.

${ }^{8}$ CARVALHO, José Murilo de, op. cit., p. 84.
} 
Ao menos uma boa parte destes bacharéis que integravam a elite política imperial dedicou-se, igualmente, ao exercício da advocacia. Para citar apenas alguns: Francisco Gê de Acaiaba Montezuma, Nabuco de Araújo, Saldanha Marinho, Franklin Dória, Tito Franco de Almeida, Antônio Ferreira Viana e Rui Barbosa. ${ }^{9}$ Um quinto dos ministros do Império eram advogados. No entanto, se consideramos apenas o período 1871-1889, observamos que quase metade dos ministros exercia a advocacia. ${ }^{10}$ Assim, na fase final da Monarquia, os advogados constituíam a maior categoria profissional no interior da elite política. ${ }^{11}$

Filhos das classes dominantes ou a elas ligados por vínculos de clientela, os juristas-políticos ${ }^{12}$ do Império mantiveram-se distantes dos projetos e reivindicações radicais e populares que se manifestaram no Brasil ao longo do século XIX. É verdade que o movimento abolicionista encontrou significativo suporte entre os bacharéis de Direito. Pode-se lembrar que Antônio Bento, o chefe dos caifazes, pertenceu à turma de 1863-1867 da Faculdade de Direito de São Paulo e que o célebre autor de Os escravos, Castro Alves, estudou Direito em Recife e, depois, em São Paulo. Entretanto, o que predominou largamente foi o compromisso dos juristas-políticos com os interesses sociais dominantes. Conforme aponta Sergio Adorno ${ }^{13}$, a faculdade de Direito (embora ele se refira à de São Paulo, pode-se afirmar o mesmo para a de Olinda/Recife), ao concentrar as alternativas de dispersão política e intelectual oferecidas aos acadêmicos (por meio do ensino formal, do periodismo, da participação em grêmios e associações

\footnotetext{
${ }^{9}$ COELHO, Edmundo Campos. As profissões liberais. Medicina, Engenharia e advocacia no Rio de Janeiro: 1822-1930. Rio de Janeiro: Record, 1999, p. 87 e 92.

${ }^{10}$ CARVALHO, José Murilo de, op. cit., p. 103.

${ }^{11}$ Ibidem, p. 86-87.

${ }^{12}$ Termo emprestado de Luiz Werneck Vianna, que o emprega em: Os intelectuais da tradição e a modernidade: os juristas-políticos da OAB. In: VIANNA, Luiz Werneck. Travessia: da Abertura à Constituinte. Rio de Janeiro: Livraria Taurus Editora, 1986.

${ }_{13}$ Sergio Adorno lista as principais características do bacharel: apreço pela retórica, pelo saber ornamental e pela erudição linguística. No mais, "identificado com a cultura europeia - inglesa, francesa e alemã - que lhe oferecia modelos de pensamento, pretendeu iluminar o caminho dos povos por meio do proselitismo das letras, resultando dai o vezo retórico, materializado na figura do intelectual-escritor. Foi educado conforme o formalismo típico da mentalidade de advogado ao conferir crédito ilimitado à juridicidade como limitação de poder e fonte de legitimidade." ADORNO, Sergio, op. cit., p. 158-159. Esta descrição, embora diga respeito ao bacharel do Império, cabe perfeitamente ao bacharel da primeira metade do século XX.
} 
estudantis e da produção artístico-literária), impediu que eles se tornassem organizadores políticos das camadas populares. ${ }^{14}$

Bem ao contrário, as faculdades de Direito foram um fator central de coesão das heterogêneas classes dominantes. A experiência escolar permitiu a convivência dos filhos das diversas oligarquias provinciais nos poucos estabelecimentos de ensino superior existentes, especialmente naqueles dedicados ao ensino jurídico. Proporcionoulhes, também, uma relativa unidade ideológica. ${ }^{15}$

O tipo-ideal do acadêmico de São Paulo, segundo Sergio Adorno, foi o bacharel liberal, cujas máximas eram a prudência e a moderação política. Ele confessava um liberalismo moderado, ou mesmo conservador, que renegava a herança da vertente radical das Revoluções Francesa e Americana e dos movimentos populares da época da Independência brasileira. Seus valores eram a propriedade, a liberdade (mais do que a igualdade), o indivíduo (mais do que a coletividade), a ordem pública e a "civilização". 16

Na passagem da Monarquia para a República, a centralidade da presença do bacharel em Direito na direção do Estado passou a sofrer duros questionamentos. Militares, positivistas e intelectuais responsabilizaram o bacharel (destacadamente, o bacharel em Direito) e o bacharelismo pelo atraso brasileiro. Acumularam-se críticas à natureza excessivamente teórica do ensino ministrado nas faculdades, à retórica vazia da qual o bacharel abusava nos pronunciamentos públicos, aos ardis dos quais se valiam para perpetuar a dominação oligárquica, ao apego aos modelos de pensamento importados e à cultura europeia (e ao seu reverso: a ignorância da realidade nacional) e a sobrevalorização do diploma como meio de distinção social e via de acesso à carreira política e aos cargos públicos. Nas primeiras décadas do século XX, o bacharelismo era

\footnotetext{
${ }^{14}$ ADORNO, Sergio, op. cit., p. 237-238.

${ }^{15}$ Para José Murilo de Carvalho, "O efeito homogeneizador da educação [sobre as elites] foi ainda reforçada pela predominância da formação jurídica". Um pouco mais adiante, ele escreve: "O ponto importante a guardar de toda a análise é que a síndrome educação superior/educação jurídica/educação em Coimbra deu à elite política da primeira metade do século [XIX] aquela homogeneidade ideológica e de treinamento que apontamos como necessária para as tarefas de construção do poder (...)." CARVALHO, José Murilo de, op. cit., p. 83-84.

${ }^{16}$ ADORNO, Sergio, op. cit., p. 158-159, 239-241, 245-246.
} 
interpretado como um anacronismo, um resquício da Monarquia, embaraçoso para o novo regime. ${ }^{17}$

Paralelamente às críticas sofridas, o bacharel passou a sofrer a competição de outros grupos na direção política do país. Revolucionários de 1930 compartilhavam as opiniões desfavoráveis ao bacharelismo e a Revolução consolidou a participação de engenheiros e militares no comando do Estado. No entanto, é preciso lembrar que vários bacharéis em Direito - a começar por Getúlio Vargas - ladearam os tenentes na chefia do movimento. É o caso dos companheiros de Vargas, que com ele formaram a "geração de 1907”, João Neves da Fontoura e Maurício Cardoso. ${ }^{18}$ Ou dos gaúchos Osvaldo Aranha e José Antônio Flores da Cunha e do mineiro Virgílio de Melo Franco.

Entre 1945 e 1964, a presença dos bacharéis no seio da elite política permaneceu incontornável. Eles perfaziam $60 \%$ de cada uma das duas maiores bancadas na Assembléia Nacional Constituinte de 1946 - a do Partido Social Democrático (PSD) e a da União Democrática Nacional (UDN). ${ }^{19}$ Pode-se supor que uma boa parte deles se enquadrasse no perfil de jurista-político criado no Império, dividindo-se entre a advocacia e a política. Na legislatura 1968-1971, 48\% dos deputados federais eram diplomados em faculdades de Direito. ${ }^{20}$ Apesar disto, é possível que a presença dos advogados na elite política brasileira, sobretudo a partir da década de 1950, tenha se enfraquecido, em virtude da ascensão política de novas profissões e da ampliação das

\footnotetext{
${ }^{17}$ COELHO, Edmundo Campos, op. cit., p. 273-274. Alberto Venâncio Filho faz um longo inventário dos autores (e de seus argumentos) que, no Império e na República, atacaram o bacharelismo como uma das causas das mazelas do país: VENÂNCIO FILHO, Alberto. Das arcadas ao bacharelismo. São Paulo: Perspectiva, 1977, p. 277-296. De sua parte, Edmundo Coelho sugere que a crítica ao bacharelismo associava-se a processos emergentes nas primeiras décadas do século XX: 1.) a saturação de diplomas superiores, que criava uma pressão social para a implementação de critérios meritocráticos para o preenchimento de cargos públicos e postos de trabalho em geral; 2.) a valorização da técnica e da ciência; 3.) a introdução de racionalidade nas profissões jurídicas pelo Código Civil de 1916; 4.) a fixação dos fundamentos cognitivos da Medicina em "sólidas bases experimentais com o desenvolvimento da bacteriologia e de novas técnicas de diagnóstico”. COELHO, Edmundo Campos, op. cit.,p. 273-274.

${ }^{18}$ LOVE, Joseph L. O regionalismo gaúcho e as origens da Revolução de 1930. São Paulo: Perspectiva, 1975 , p. 90.

${ }^{19}$ MICELI, Sergio. Carne e osso da elite política brasileira pós-1930. In: FAUSTO, Boris (direção). História Geral da Civilização Brasileira. Rio de Janeiro: Bertrand Brasil, 1996, tomo III, volume 3, p. 560-561. O universo dos parlamentares do PSD e da UDN que o autor analisa não é total, mas os seus dados referem-se à grande maioria dos senadores e deputados constituintes dos dois partidos.

${ }^{20}$ LIMA JR., Olavo Brasil de; KLEIN, Lúcia Maria Gomes; MARTINS, Antônio Soares. O advogado e o Estado no Brasil. Rio de Janeiro: Edições Dados, 1970, p. 2-3.
} 
carreiras de nível superior proporcionada pela abertura de novos cursos e pela industrialização. Na legislatura iniciada em 1983, 60,6\% dos deputados federais eram formados em Direito, porém apenas 14,2\% eram advogados ou juízes. ${ }^{21}$

\section{O Instituto dos Advogados Brasileiros (IAB)}

Em 1843, foi fundado o Instituto dos Advogados Brasileiros (IAB). Tratava-se de uma associação de filiação voluntária e que congregava a elite dos advogados do Império. No Império, o Instituto pretendeu dedicar-se tanto ao aprimoramento do exercício da advocacia quanto ao aperfeiçoamento da legislação e jurisprudência do país. A participação na vida pública distinguia os advogados e jurisconsultos associados ao IAB desde a sua fundação. ${ }^{22}$ A maioria dos 36 sócios fundadores do Instituto era formada por magistrados (no decorrer do tempo, os advogados passaram a ser mais numerosos que os juízes). Ademais, como demonstra Eduardo Pena, $3 / 4$ deles já haviam exercido ou ainda exerciam cargos políticos na Corte, como deputados gerais, senadores e conselheiros de Estado. Outros três eram ministros de Estado: Honório Hermeto Carneiro Leão (Justiça), José Antônio da Silva Maia (Interior) e Paulino José Soares de Sousa (Negócios Estrangeiros). ${ }^{23}$ Francisco Montezuma foi o primeiro presidente do Instituto. Deputado constituinte em 1823 e ministro dos Negócios Estrangeiros durante a Regência, Montezuma ocupou o cargo até 1851, quando assumiu uma cadeira no Senado. ${ }^{24}$ Eduardo Pena contabilizou o exercício de funções públicas de primeira importância pelos sócios do IAB durante o Império. Dentre os 457 sócios do Instituto no período, houve 126 deputados ou senadores, 28 conselheiros de Estado, 46 ministros do Império e 77 presidentes de província. ${ }^{25}$

\footnotetext{
${ }^{21}$ FALCÃO, Joaquim. Os advogados: ensino jurídico e mercado de trabalho. Recife: Fundação Joaquim Nabuco/Editora Massangana, 1984, p. 147.

${ }^{22}$ BONELLI, Maria da Gloria. Profissionalismo e política no mundo do Direito: as relações dos advogados, desembargadores, procuradores de justiça e delegados de polícia com o Estado. São Carlos: EdUFSCar/Editora Sumaré, 2002, p. 14, 30, 40-50; OLIVEIRA, João Gualberto de. História dos órgãos de classe dos advogados. São Paulo: [s.n]., 1968, p. 221-227.

${ }^{23}$ PENA, Eduardo Spiller. Pajens da casa imperial: jurisconsultos e escravidão no Brasil do século XIX. Campinas, 1998. Tese (Doutorado em História). UNICAMP, p. 25-26.

${ }^{24}$ BONELLI, Maria da Gloria, op. cit., p. 43-44.

${ }^{25}$ PENA, Eduardo Spiller, op. cit., p. 26-30.
} 
Já no seu discurso de posse, Montezuma acentuou o compromisso do Instituto com o aperfeiçoamento da advocacia em torno de determinados valores e listou os atributos imprescindíveis aos advogados: honestidade, probidade, moderação e delicadeza. Ademais, o presidente afirmou a necessidade de o advogado ser fiel ao Imperador e zelar pela liberdade e pela Constituição. ${ }^{26}$ Os presidentes subseqüentes contribuíram, igualmente, para moldar uma "ética da profissão" e um modelo ideal de advogado - que seriam inteiramente incorporados pela elite dos advogados instalada na direção da OAB a partir de 1930. Em discurso pronunciado em 1857, o presidente do Instituto, Caetano Alberto Soares afirmou que o advogado deveria ser capaz de "sacrifício constante e generoso de seus divertimentos e prazeres, e da própria liberdade em bem da justiça e da humanidade" e de "um zelo ardente de socorrer o desgraçado, de defender o inocente; uma nobre franqueza para falar sempre a linguagem da verdade, quaisquer que sejam as circunstâncias, e mais que tudo, um desinteresse tal, que nada possa alterar a grandeza d'alma que o deve caracterizar". ${ }^{27}$ Para que o ofício fosse praticado em torno de tão altos valores e nobres objetivos, o Instituto considerava fundamental a sua ação disciplinadora sobre a categoria. No mesmo discurso acima citado, Soares sublinhou a necessidade de se estabelecer "uma vigilância protetora de sua própria [do advogado] dignidade." Ao assumir a presidência do IAB, em 1866, Nabuco de Araújo retomou o tema:

“(...) a independência da profissão exige que os advogados não vivam isolados, mas constituam uma ordem, que se governe a si mesma por meio de seus mandatários, e possa pela inspeção, pela disciplina e pela emulação, manter a honra, a glória e as tradições dessa profissão. "28

O aprimoramento da administração da justiça e da legislação foi outro eixo de atuação do IAB durante o Império - o que reforçava o discurso de seus sócios em

\footnotetext{
${ }^{26}$ Ibidem, p. 32.

27 Apud PENA, Eduardo Spiller, op. cit., p. 34.

${ }^{28}$ Apud PENA, Eduardo Spiller, op. cit., p. 34-35.
} 
relação à dimensão pública da ação do Instituto. Neste domínio, a codificação das leis civis era constantemente mencionada pelos presidentes do IAB como uma tarefa

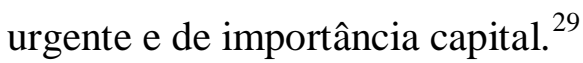

Saldanha Marinho, presidente do Instituto por quase vinte anos, em discurso pronunciado em 1875, sintetizou os objetivos a serem perseguidos pela instituição, mencionando o aperfeiçoamento das leis e da administração da justiça, de um lado, e a proteção e o aprimoramento da advocacia, de outro:

"Ocupe-se ele [о IAB] seriamente das questões jurídico-sociais que mais interessam ao país; trate de firmar em bases sólidas a ciência das leis, a jurisprudência; representem aos poderes do Estado por bem de que sejam adotadas as medidas indispensáveis à estabilidade dos direitos e à proscrição dos abusos; constitua-se vigilante do procedimento dos juízes e tribunais - para, nas suas atribuições, estigmatizar o erro, ou o crime, e, se possível for, representar às autoridades competentes contra os que deixarem de honrar o seu encargo; esforce-se por constituir a profissão de advogado na altura e na nobreza indispensáveis; esforce-se, dando o exemplo, por escoimar do foro os mercadores da lei; satisfaça assim o fim principal de sua instituição - e bem merecerá do país. "30

Ao longo do período monárquico, o IAB conheceu momentos de intervenção direta na vida política do país, ainda que tenha predominado uma atuação voltada à prática forense e aos debates teóricos. ${ }^{31} \mathrm{Em}$ 1880, em razão de uma reforma estatutária, passou a denominar-se Instituto da Ordem dos Advogados Brasileiros (IOAB). ${ }^{32} \mathrm{Na}$ Primeira República, o Instituto continuou a perseguir o duplo objetivo de contribuir para

\footnotetext{
${ }^{29}$ PENA, Eduardo Spiller, op. cit., p. 36-38.

${ }^{30}$ Apud BONELLI, Maria da Gloria, op. cit., p. 48.

${ }^{31}$ FAGUNDES, Laura. Instituto dos Advogados Brasileiros: 150 anos de história, 1843-1993. Rio de Janeiro: IAB/Destaque, 1995, p. 31, 68-69.

${ }^{32}$ GUIMARÃES, Lúcia Maria Paschoal; BESSONE, Tânia; MOTTA, Marly Silva da. História da Ordem dos Advogados do Brasil. O IAOB na Primeira República. Brasília: OAB, 2003, v. 3, p. 19.
} 
o aperfeiçoamento da advocacia e da distribuição da justiça. ${ }^{33}$ Desde o Segundo Reinado, e prosseguindo na República, o Instituto era consultado pelo governo a respeito de questões jurídicas. ${ }^{34}$ A colaboração com o governo ajudou a forjar o prestígio do IAB, mas, por outro lado, tornava frágil sua autonomia - ainda que formalmente não pertencesse ao aparato estatal.

\section{Estratificação da categoria dos advogados}

Edmundo Coelho analisou a estratificação da categoria dos advogados no Império. Uma distinção evidente na categoria dos advogados era a posse (ou a falta) de um diploma. Os custos para a formação de um bacharel eram razoáveis. Os recursos necessários à manutenção do estudante (quando vinha de outra cidade ou província) bem como ao pagamento das taxas de matrícula mantinham o diploma como um apanágio de um grupo reduzido. ${ }^{35}$ Em pronunciamento feito na Câmara dos Deputados, Francisco Inácio de Carvalho Moreira, o futuro barão de Penedo, reconheceu que, se as taxas de matrícula cobradas pelas faculdades não tinham grande peso na arrecadação do Estado, elas tinham a virtude de manterem os aspirantes menos afortunados distantes dos cursos superiores. ${ }^{36}$

Contudo, mesmo entre os advogados portadores de graus acadêmicos havia diferenças profundas. Havia um "baixo clero" da advocacia diplomada, possivelmente dispersa pelo interior do país, que vivia com relativa simplicidade. Mas era justamente a

\footnotetext{
${ }^{33}$ Ibidem, p. 19-131.

${ }^{34}$ FAGUNDES, Laura, op. cit., p. 19 e 32. GUIMARÃES, Lúcia Maria Paschoal; BESSONE, Tânia; MOTTA, Marly Silva da. História da Ordem dos Advogados do Brasil. O IAOB na Primeira República. op. cit., p. 131.

35 "De modo geral, os alunos das escolas de Direito provinham de famílias de recursos. As duas escolas cobravam taxas de matrícula (...) Além disso, os alunos que não eram de São Paulo ou do Recife tinham que se deslocar para essas cidades e manter-se lá por cinco anos. Muitos, para garantir a admissão, faziam cursos preparatórios ou pagavam repetidores particulares. Esses cursos eram obstáculos sérios para alunos pobres, embora alguns deles conseguissem passar pelo peneiramento." CARVALHO, José Murilo de, op. cit., p. 74-75.

${ }^{36}$ COELHO, Edmundo Campos, op. cit., p. 101.
} 
estes modestos advogados e, também, aos $\operatorname{práticos}^{37}$ que a grande maioria da população tinha acesso - incluindo os escravos que quisessem iniciar uma ação de liberdade. ${ }^{38}$ Remunerados modestamente, o "baixo clero" da advocacia e os práticos procuravam se esquivar como podiam do pagamento de custos e impostos. Muitos advogados deixavam de solicitar o seu diploma para não terem de arcar com os custos de sua emissão, procurando apenas com a colação de grau. Era o caso de bacharéis admitidos no funcionalismo público e que advogavam nas horas livres. Outros advogados e práticos tentavam fugir do imposto cobrado dos escritórios de advocacia atendendo a sua clientela na rua, nas imediações dos tribunais. ${ }^{39}$ Baseando-se nas listas eleitorais da cidade do Rio de Janeiro de 1876 (que contêm informações sobre a ocupação/profissão e o rendimento anual dos eleitores da Corte), Edmundo Coelho propõe o seguinte perfil da estratificação dos advogados (aparentemente, ele trata apenas dos advogados formados): uma base relativamente pequena (cerca de 20\%), um amplo estrato intermediário (quase 75\%) e um reduzido estrato superior (cerca de 5\%), que era formado pela elite dos advogados. ${ }^{40}$

Para Edmundo Coelho, a distinção fundamental entre aqueles que se dedicavam à advocacia era a que separava a pequena elite dos advogados da massa dos advogados diplomados e dos rábulas. E esta distinção fundava-se em hábitos culturais, extração social da clientela e relações sociais ${ }^{41}$. A diferenciação era estabelecida pela elite dos advogados, que se definia como dotada de um senso de missão em contraposição aos “mercadores do Direito". ${ }^{2}$ Uma parte considerável destes advogados de elite dedicava-

\footnotetext{
${ }^{37}$ Os termos práticos e rábulas são empregados neste trabalho - sem qualquer conotação pejorativa para designar os profissionais (provisionados e solicitadores) que se dedicavam à advocacia, ainda que não tivessem um diploma de Direito.

${ }^{38}$ COELHO, Edmundo Campos, op. cit.,p. 91.

${ }^{39}$ Ibidem, p. 98-100.

${ }^{40}$ Ibidem, p. $77-84$.

41 Ibidem, p. 76.

${ }^{42}$ Um trecho do discurso pronunciado pelo conselheiro Saldanha Marinho na sessão de 7 de setembro de 1875 do Instituto dos Advogados Brasileiros revela a representação que os advogados de elite tinham de si mesmos. Saldanha Marinho cuidava para que não se confundisse "o advogado com o mercador do Direito, com o corretor da justiça, com o réptil do foro que por aí se arrasta em busca somente de sórdido lucro (...) Probidade, desinteresse, independência, devotamento, abnegação, trabalho incessante, ciência, amenidade no trato, sem quebra da indispensável energia, tais são os atributos indispensáveis
} 
se, igualmente, à política e à administração pública. E era antes ao exercício de mandatos parlamentares e funções públicas que deviam o seu prestígio social que à prática da advocacia. A elite dos advogados monopolizava o ofício nos tribunais superiores. E recebia vultosos honorários pela elaboração de pareceres encomendados por clientes abastados. Profissionais conceituados como Antônio Rebouças, Franklin Dória, Francisco Inácio de Carvalho Moreira e Rui Barbosa preparavam pareceres para empresas estrangeiras e nacionais. ${ }^{43}$ A clientela destes advogados de elite era reduzida e os seus serviços profissionais inacessíveis à grande maioria da população. Estes advogados estavam distantes não apenas dos outros advogados e dos práticos, mas, sobretudo, do restante da sociedade, circulando num meio social extremamente restrito. ${ }^{44}$ Assim, os advogados de elite, os advogados anônimos ou modestos, os provisionados e solicitadores não constituíam uma comunidade profissional, pois nada os reunia, nem interesses, nem valores. ${ }^{45}$

A estratificação da categoria profissional adentrou o período republicano. ${ }^{46} \mathrm{Com}$ a progressiva extinção dos práticos, a partir de 1930, a posse do diploma superior perdeu importância como critério de distinção entre os que se dedicavam à advocacia. De todo modo, o perfil do estrato superior da categoria profissional manteve-se, em

aqueles que quiserem ter o direito ao nome de advogado (...)."Apud COELHO, Edmundo Campos, op. cit., p. 172.

${ }^{43}$ COELHO, Edmundo Campos, op. cit., p. 77, 87-88, 92-93.

44 "Seja como for, fechados em seus escritórios, afastados do povo, é pouco provável que o homem das ruas tomasse conhecimento da existência desses ilustres cidadãos. Menos provável ainda que os ilustres cidadãos tomasse conhecimento da existência do povo. Logo, o prestígio de que desfrutavam tenha limitado raio e era a rigor distribuído inter pares. À semelhança da elite dos médicos, circulava a dos advogados num meio social extremamente rarefeito e homogêneo." COELHO, Edmundo Campos, op. cit., p. 94.

${ }^{45}$ COELHO, Edmundo Campos, op. cit., p. 177.

${ }^{46}$ O depoimento de Paulo César Costeira, conselheiro da seção da OAB da Guanabara desde 1968, é ilustrativa a este respeito. Evidentemente, trata-se de um juízo impressionista, carente de dados estatísticos, mas qualificado por uma vivência de algumas décadas no seio da elite dirigente dos advogados do Rio de Janeiro. O depoimento, concedido por Costeira a Renato Lessa e Leila Linhares aborda a situação dos advogados no início da década de 1990: "O perfil social do advogado (...) a gente pode dividir em três. Tem os advogados bem situados, eu não diria ricos, eu diria uns cinco por cento da categoria. Os advogados médios, vamos chamar de uma classe média (...) eu diria vinte e cinco por cento. E setenta por cento são advogados pobres. Agravado pelo mercado de trabalho que é muito dificil..." LESSA, Renato; LINHARES, Leila. Consenso e identidade: os advogados e a sua ordem. Rio de Janeiro: OAB - Rio de Janeiro, 1991, p. 105. Há, provavelmente, um grande exagero na estimativa de que quase $3 / 4$ da categoria sejam pobres, mas o que me parece válido é o reconhecimento da estratificação social entre os advogados. 
vários aspectos, semelhante ao que fora no Império. Os advogados de elite da República também se dedicavam à política e exerciam seu ofício nos tribunais superiores, tendo grandes empresas na sua clientela. A partir da década de 1950, a condição de trabalho começou a diferenciar o estrato superior dos outros, ainda que critérios antigos, como origem social e universidade cursada, predominassem. O processo de assalariamento da profissão atingiu, especialmente, os estratos inferiores dos advogados. Como a condição de trabalho tradicional, a do profissional autônomo, permaneceu valorizada no interior da categoria profissional, os advogados assalariados eram desprestigiados por seus colegas. ${ }^{47}$ Esta realidade é revelada pelo depoimento concedido a Renato Lessa e Leila Linhares por Benedito Calheiros Bonfim, conselheiro da OAB da Guanabara desde 1968 e presidente do IAB na década de 1990:

"Ainda era uma época em que o advogado, isso mais ou menos até 50, era tão pequeno o número de advogados assalariados, que embora eu não o fosse, a não ser nesse pequeno período em que estive no Sindicato dos Bancários, soava de maneira pejorativa o advogado dizer que era empregado. Porque o que dominava era o profissional liberal típico e o número, com a industrialização, o

\footnotetext{
${ }^{47}$ Infelizmente, não há dados estatísticos sobre o tipo predominante de advocacia praticada no período democrático. É razoável supor que, a despeito do crescimento da advocacia assalariada, o padrão tradicional (o profissional autônomo que atende a clientela no seu escritório) continuasse dominante. Segundo Maria da Gloria Bonelli, só existem dados confiáveis sobre o perfil do advogado brasileiro a partir da década de 1990. Esta autora apresenta uma pesquisa realizada em 1996 pelo Conselho Federal da $\mathrm{OAB}$ entre os inscritos da entidade. $\mathrm{O}$ levantamento indicou que $61 \%$ dos entrevistados eram advogados autônomos, $10 \%$ também eram autônomos, porém associados a escritórios, $10 \%$ eram empregados do setor privado, $8 \%$ eram empregados no setor público e $9 \%$ eram sócios de escritório. Em relação à área de atuação principal, $63 \%$ dedicavam-se à advocacia forense, $15 \%$ à advocacia de empresa, $10 \%$ à advocacia consultiva e 6\% à advocacia pública. BONELLI, Maria da Gloria, op. cit., p. 62-63. Não há qualquer razão para se supor que a advocacia assalariada tenha sofrido qualquer refluxo desde a década de 1950; pelo contrário, a expansão do capitalismo e do aparelho de Estado no país deve ter sustentado, desde então, uma tendência de crescimento da advocacia assalariada. Assim, se os dados da pesquisa refletirem a situação da categoria profissional no conjunto, há motivos para se afirmar que o padrão liberal nunca deixou de ser dominante na profissão. Entretanto, parece-me que o levantamento realizado pela $\mathrm{OAB}$ padece de uma fragilidade importante, pois ele abrangeu 1.700 advogados escolhidos aleatoriamente, num universo de cerca de 400 mil profissionais. De sua parte, Joaquim Falcão, em trabalho do início da década de 1980, afirma: "A grande maioria dos advogados, hoje, são assalariados (...) São assalariados os advogados que trabalham na Administração Pública, os que trabalham, mas não são sócios nas sociedades de advogados, os que trabalham nos departamentos jurídicos, e nos serviços político-legais para a população baixa renda. FALCÃO, Joaquim, op.cit., p. 169. Entretanto, o autor não apresenta quaisquer dados empíricos para sustentar tal assertiva.
} 
crescimento econômico do país, começava a se formar um outro segmento embora ainda muito limitado, que era desses empregados assalariados, que eram mal vistos, porque assim com se fosse uma espécie de terceira categoria, em relação aos quais havia uma certa subestimação, senão menosprezo. Aqueles advogados não podiam imaginar que alguém recebesse um salário e pudesse, ao mesmo tempo, ser um profissional liberal. Para eles era uma descaracterização da profissão", 48

\section{Ensino de Direito e mercado de trabalho}

Durante o Império, os bacharéis em Direito enfrentaram o problema da inflação de diplomas. Logo, a magistratura se tornou uma carreira concorrida. A expansão da advocacia, beneficiada pelo desenvolvimento do país, aliviou a concorrência pelos postos de juízes. Porém, o mercado de trabalho para advogados também se saturou. De acordo com o censo de 1872, havia, em todo o Brasil, 968 juízes e 1.647 advogados. Os muitos bacharéis que não logravam ingressar na magistratura ou na advocacia buscavam uma colocação - ainda que modesta - na burocracia estatal. ${ }^{49}$

A partir de 1891, as instituições públicas perderam o monopólio do ensino superior no Brasil. A Reforma Benjamin Constant (Decreto $n^{\circ} 1.232$, de 2 de janeiro de 1891), permitiu a criação de faculdades privadas, desde que autorizadas e fiscalizadas pelo poder público. À abolição do exclusivismo seguiu-se a disseminação de estabelecimentos de ensino superior pelo país sob a direção de particulares e da Igreja. Assim, as Faculdades de Direito de São Paulo e do Recife, que reinaram soberanas durante o Império, ganharam concorrentes logo no início do período republicano. ${ }^{50} \mathrm{Em}$ consequiência, o ensino jurídico expandiu-se nas primeiras décadas do período republicano. Em 1907, havia dez faculdades de Direito no país, com 2.481 alunos matriculados. Em 1929, eram 14 estabelecimentos e 3.200 estudantes (Tabela 1). Já neste período, a inflação de diplomas de Direito era uma realidade. Ela foi enfrentada

\footnotetext{
${ }^{48}$ LESSA, Renato; LINHARES, Leila, op. cit., p. 26.

${ }^{49}$ CARVALHO, José Murilo de, op. cit., p. 86-87.

${ }^{50}$ MICELI, Sergio. Intelectuais e classe dirigente no Brasil (1920-45). In: MICELI, Sergio. Intelectuais à brasileira. São Paulo: Companhia das Letras, 2001, p. 115-116.
} 
pela elite dos advogados, fundamentalmente, com duas ações: a tentativa de frear a expansão das vagas disponíveis nas faculdades de Direito e o cerceamento do exercício da advocacia, tornando-a, tanto quanto possível, privilégio dos portadores de diploma o que significava, no mínimo, restringir a atuação profissional dos rábulas. ${ }^{51}$ Neste contexto, alguns estados tentaram regular a prática do ofício, estabelecendo uma reserva de mercado para os advogados formados. Uma lei mineira de 1920 proibiu a concessão e a renovação de autorização para que os provisionados e solicitadores pudessem advogar. ${ }^{52}$ Entretanto, a limitação do exercício da advocacia apenas foi obtida eficazmente com a criação da OAB. ${ }^{53}$

Tabela 1: Ensino de Direito no Brasil (1907-1958)

\begin{tabular}{cccc}
\hline Ano & unidades escolares & matrículas & conclusões de curso \\
\hline $\mathbf{1 9 0 7}$ & 10 & 2481 & - \\
$\mathbf{1 9 0 8}$ & 10 & 2479 & - \\
$\mathbf{1 9 0 9}$ & 10 & 2471 & - \\
$\mathbf{1 9 1 0}$ & 10 & 2186 & - \\
$\mathbf{1 9 1 1}$ & 10 & 2538 & - \\
$\mathbf{1 9 1 2}$ & 15 & 2728 & - \\
$\mathbf{1 9 2 7}$ & 13 & 2525 & - \\
$\mathbf{1 9 2 8}$ & 13 & 2707 & - \\
\hline
\end{tabular}

51 O problema da intensificação da concorrência profissional e as estratégias acima descritas para enfrentá-las também marcaram a Medicina e a Engenharia na Primeira República. Cf. COELHO, Edmundo Campos, op. cit.

${ }^{52}$ COELHO, Edmundo Campos, op. cit., p. 272.

53 Aurélio Wander Bastos admite que os pleitos da elite dos advogados pela organização de uma corporação relacionavam-se, antes de mais nada, à luta contra os práticos: "Neste sentido, até o fim da Primeira República, a história do exercício da advocacia no Brasil é a história do confronto (e da convivência) entre os rábulas, provisionados pelo Estado Imperial (Poder Moderador, Executivo e Judiciário) e pelo Estado republicano, e os bacharéis, formados pelas escolas oficiais de Direito. Estes confrontos entre os rábulas provisionados e a ascendente advocacia de bacharéis pela ocupação de espaços institucionais e judiciais levou à organização corporativa dos advogados a evoluir mais em função dos enfrentamentos práticos da profissão do que, propriamente, sob a inspiração dos ideais iluministas e das conquistas dos advogados franceses com a promulgação do Decreto de 1810, de Napoleão Bonaparte que restaura e reorganiza a velha corporação francesa dos advogados (Barreau)." BASTOS, Aurélio Wander. A Ordem dos Advogados e o Estado democrático no Brasil. Rio de Janeiro, 2007. Tese (Doutorado em Ciência Política). IUPERJ, p. 67-68. 


\begin{tabular}{|c|c|c|c|}
\hline 1929 & 14 & 3200 & 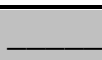 \\
\hline 1932 & 26 & 6448 & 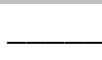 \\
\hline 1933 & 30 & 7818 & 900 \\
\hline 1934 & 34 & 8515 & 201 \\
\hline 1935 & 36 & 9861 & 1304 \\
\hline 1936 & 33 & 10049 & 1217 \\
\hline 1937 & 28 & 9112 & 1506 \\
\hline 1938 & 24 & 7681 & 1780 \\
\hline 1939 & 23 & 6615 & 1686 \\
\hline 1940 & 22 & 5793 & 1285 \\
\hline 1941 & 23 & 5629 & 1061 \\
\hline 1942 & 21 & 5523 & 776 \\
\hline 1943 & 21 & 5829 & 1023 \\
\hline 1944 & 21 & 6139 & 963 \\
\hline 1945 & 21 & 6520 & 992 \\
\hline 1946 & 22 & 6773 & 1045 \\
\hline 1947 & 23 & 7758 & 1023 \\
\hline 1948 & 23 & 8722 & 947 \\
\hline 1949 & 24 & 9764 & 1283 \\
\hline 1950 & 25 & 11454 & 1321 \\
\hline 1951 & 29 & 13946 & 1634 \\
\hline 1952 & 34 & 15440 & 1922 \\
\hline 1953 & 39 & 16977 & 1996 \\
\hline 1954 & 40 & 17539 & 2215 \\
\hline 1955 & 38 & 19921 & 2779 \\
\hline 1956 & 40 & 20634 & 2619 \\
\hline 1957 & 42 & 21063 & 3065 \\
\hline 1958 & 46 & 21708 & \\
\hline
\end{tabular}

Fontes: Sinopse retrospectiva do ensino no Brasil - 1871/1954. Rio de Janeiro: IBGE, 1956, p. 24, 29 e 30; Sinopse retrospectiva do ensino no Brasil - 1933/1958. Rio de Janeiro: IBGE, c. 1958, p. 9. 
A oferta de bacharéis acentuou-se na década de 1930. No início desta, o número de alunos de Direito dobrou em relação ao final da década anterior. As dificuldades dos bacharéis em encontrar uma ocupação intensificaram-se pela concorrência de profissionais diplomados em novas especialidades (Filosofia, Educação ou Ciências e Letras), que passaram a exercer atividades antes destinadas aos bacharéis em Direito, como, por exemplo, o ensino de humanidades. ${ }^{54}$

De acordo com Sergio Miceli o quadro de intensificação da concorrência profissional e o conseqüente risco de perda de prestígio social favoreceram o engajamento de bacharéis no integralismo, nas organizações políticas da Igreja ou nos agrupamentos de esquerda com o intuito de conquistar o Estado e impor uma nova elite dirigente (a ser formada pelos bacharéis ligados às respectivas organizações). Miceli observa ainda que muitos dos militantes do movimento integralista ou das organizações católicas só ingressaram decididamente nestas causas depois de 1932, quando ficou nítida a derrota política das oligarquias às quais estavam vinculados. ${ }^{55}$

Entretanto, a pressão por postos de trabalho foi dirimida pela expansão do aparelho estatal, que passou a absorver - ao menos em parte - os bacharéis ociosos. ${ }^{56} \mathrm{O}$ crescimento da oferta de emprego público deve ter atuado como um importante instrumento de cooptação de bacharéis pelo governo Vargas, criando uma base de apoio para este no interior da categoria dos advogados.

Ao longo da década de 1940, a oferta de bacharéis manteve-se constante. Em 1940, as faculdades de Direito do país formaram 1.285 alunos e em 1949, 1.283 (Tabela 1). Os dados disponíveis sobre o número de advogados em atividade no país (Tabela 2) também sugerem que a oferta de serviços de advocacia também foi contida ao longo desta década, com um crescimento relativamente modesto do número de advogados. Em 1942, havia cerca de 13.000 advogados no país; em 1950, eles eram 15.566, o que significou um crescimento de quase $20 \%$ do número de profissionais.

\footnotetext{
${ }^{54}$ MICELI, Sergio. Intelectuais e classe dirigente no Brasil (1920-45), op. cit., p. 118.

${ }_{55}^{55}$ Ibidem, p. 118-119.

${ }^{56}$ Ibidem,, p. 118-120.
} 
Tabela 2: Número de advogados no Brasil (1933-1970)

\begin{tabular}{cc}
\hline Ano & número de advogados \\
\hline $\mathbf{1 9 3 3}^{\mathbf{5 7}}$ & 6796 \\
$\mathbf{1 9 3 4}$ & 8161 \\
$\mathbf{1 9 4 2}$ & $13000^{58}$ \\
$\mathbf{1 9 5 0}$ & 15566 \\
$\mathbf{1 9 6 0}$ & 30066 \\
$\mathbf{1 9 7 0}$ & 37719
\end{tabular}

Fontes: GUIMARÃES, Lúcia Maria Paschoal; BESSONE, Tânia. História da Ordem dos Advogados do Brasil. Criação, primeiros percursos e desafios (1930-1945). Brasília: OAB, 2003 , v. 4, p. 48; VENÂNCIO FILHO, Alberto. Notícia histórica da OAB, 1930-1980. São Paulo: Conselho Federal da OAB, 1982, p. 45 e 62; FALCÃO, Joaquim. Os advogados: ensino jurídico e mercado de trabalho. Recife: Fundação Joaquim Nabuco/Editora Massangana, 1984, p. 180.

No entanto, na década de 1950, segundo todos os dados estatísticos, houve uma explosão tanto do número de advogados em atividade quanto do número de bacharéis em Direito. Em menos de uma década, o número de formados pelos cursos jurídicos mais do que dobrou (Tabela 1). Em 1950, eles eram 1.321; em 1957, 3.065. Em 1960, havia 30.066 advogados no país (Tabela 2), o que significa dizer que o número de advogados duplicou ao longo da década de 1950. Ainda vale a pena citar o dado de que, em 1950, existiam, no Brasil, 31.302 bacharéis em Direito; em 1960, eles eram 55.613 (Tabela 3). ${ }^{59}$

\footnotetext{
${ }^{57}$ Não estão contabilizados os advogados do Mato Grosso, Paraná e Acre.

58 Número aproximado.

${ }^{59} \mathrm{O}$ crescimento do número de formados pelas faculdades de Direito em proporção maior do que o mercado de serviços jurídicos - aparentemente um fenômeno que atravessou os séculos XIX e XX obrigou muitos dos bacharéis a procurarem ocupação em áreas alheias à de sua formação. Joaquim Falcão, numa pesquisa sobre os bacharéis formados pela Faculdade de Direito do Recife entre 1930 e 1975, demonstra que, dentre os que trabalhavam no setor público, 62,3\% desempenhavam uma atividade não-jurídica. Dentre os que trabalhavam no setor privado, o percentual era de 59,3\%. FALCÃO, Joaquim, op.cit., p. 146-147.
} 
Tabela 3: Número de bacharéis em Direito no Brasil (1950-1970)

\begin{tabular}{cc}
\hline ano & número de bacharéis \\
\hline $\mathbf{1 9 5 0}$ & 31302 \\
$\mathbf{1 9 6 0}$ & 55613 \\
$\mathbf{1 9 7 0}$ & 91132 \\
\hline
\end{tabular}

Fonte: FA $\overline{\mathrm{LCA} O}$, Joaquim. Os advogados: ensino jurídico $e$ mercado de trabalho. Recife: Fundação Joaquim Nabuco/Editora Massangana, 1984, p. 180.

Finalmente, na década de 1960, a expansão do número de advogados foi bastante menos intensa - o que pode ter sido resultado da saturação do mercado de trabalho. Todavia, o número de bacharéis em Direito elevou-se enormemente - o que demonstra o fracasso da $\mathrm{OAB}$ em frear a expansão dos cursos de Direito.

\section{A regulamentação do exercício da advocacia}

O Império manteve a legislação colonial para o exercício da advocacia, reconhecendo três categorias de profissionais: a dos bacharéis em Direito, a dos provisionados e a dos solicitadores. Ao bacharel em Direito bastava a apresentação do diploma para atuar em qualquer tribunal. O provisionado, não tendo cursado uma faculdade de Direito, era submetido, pelo Judiciário, a exames práticos e teóricos de jurisprudência. Aprovado, tinha o direito de advogar em tribunais de primeira instância e nas localidades em que o contingente de advogados formados fosse considerado insuficiente. O solicitador também não possuía diploma, mas era submetido tão somente a um exame sobre a prática processual. ${ }^{60}$ De todo modo, segundo o juízo de Edmundo Coelho, o que prevaleceu durante o Império foi uma ampla liberdade profissional no campo da advocacia, que frequentemente contornava ou mesmo ignorava as restrições da legislação. ${ }^{61}$ Esta situação beneficiava-se do fato de que uma razoável gama de

\footnotetext{
${ }^{60}$ COELHO, Edmundo Campos, op. cit., p. 167.

${ }^{61}$ Ibidem, p. 293-294. "O grosso da advocacia era feito por advogados provisionados, por solicitadores ou mesmo por leigos e não era raro que rábulas estabelecessem reputação de notório saber jurídico, como fora o caso de Antonio Pereira Rebouças no Império, ou de Evaristo de Moraes ao fim do século. É exato que muito da liberdade profissional no campo da advocacia era exercido na esfera criminal, um
} 
atividades usualmente associadas à advocacia podia ser exercida por qualquer pessoa, desde que munida de procuração assinada por uma das partes em litígio. Ademais, em algumas circunstâncias, uma parte podia representar a si mesma diante dos juízes. ${ }^{62}$

A organização de uma corporação - que estabeleceria as condições para o exercício da profissão -, inspirada em instituições como a Ordem dos Advogados de Paris ou de Lisboa, foi um objetivo manifesto do IAB desde a sua fundação. O segundo artigo do primeiro estatuto do Instituto dizia: "O fim do Instituto é organizar a Ordem dos Advogados, em proveito geral da ciência da jurisprudência.",63 No Império, ao menos dois projetos de lei foram apresentados ao parlamento com este propósito. $\mathrm{O}$ primeiro, em 1851, foi aprovado pelo Senado, mas não pela Câmara dos Deputados. O segundo, em 1880, não obteve andamento. Este último, apresentado por Saldanha Marinho, então presidente da IAB, enfatizava os aspectos disciplinares da ordem a ser criada, prevendo penas de multa, advertência, censura, suspensão da matrícula por tempo determinado e mesmo cancelamento da matrícula do advogado faltoso. Além disto, o projeto interpretava a advocacia como um múnus público, uma atividade a serviço do bem comum. Na Primeira República, prosseguiram as démarches para a criação da corporação, como foi o caso do projeto de lei apresentado à Câmara dos Deputados pelo deputado Celso Baima, em 1911. ${ }^{64}$

Ao ponderar sobre as razões dos fracassos das tentativas de criação da Ordem durante o Império, Eduardo Coelho lista quatro hipóteses: 1.) A falta de compromisso para com a advocacia dos bacharéis que eram também políticos ilustres. Para alguns destes, a profissão tinha pouca importância na carreira, significando apenas uma "estação" onde eles esperavam pelo próximo cargo público. 2.) O zelo liberal de alguns sócios contra a formação de uma corporação de filiação compulsória e que potencialmente exerceria um controle despótico sobre os seus filiados (como ocorria com a Ordre des Avocats de Paris). 3.) A fragilidade do IAB, que contava com pequena

território pouco respeitável quando não era iluminado, por ocasião das causes célèbres, pela luz de astros da grandeza de Franklin Dória, o barão de Loreto." COELHO, Edmundo Campos, op. cit., p. 235.

${ }^{62}$ COELHO, Edmundo Campos, op. cit., p. 90-91.

63 Apud VENÂNCIO FILHO, Alberto. Das arcadas ao bacharelismo, op. cit., p. 14.

${ }^{64}$ Ibidem, p. 14-20. 
participação dos seus sócios nas suas atividades e discreto engajamento nas suas iniciativas. 4.) As resistências estatais à concessão de autonomia corporativa aos advogados. ${ }^{65}$ Maria da Gloria Bonelli afirma que o fator decisivo para as sucessivas derrocadas do projeto de organização de uma corporação de advogados no Império e na Primeira República foi o receio dos políticos de que ela se constituísse num poder concorrente às instituições políticas existentes. ${ }^{66}$

A criação da OAB, em 1930, permitiu que a elite dos advogados assumisse, a partir de então, a regulamentação da profissão. Dentre suas preocupações corporativas, a mais importante, ao lado da moralização da categoria profissional, era o controle da oferta de serviços - abundante, então, pela expansão das faculdades de Direito. A direção da $\mathrm{OAB}$ adotou três medidas para tanto: 1.) interditou o exercício da advocacia para uma parte dos bacharéis: juízes, membros do Ministério Público e funcionários públicos, especialmente da polícia e da Fazenda. ${ }^{67}$ 2.) reservou a grande maioria dos atos judiciais aos inscritos na $\mathrm{OAB}$, sobretudo aos advogados. O parágrafo $2^{\circ}$ do artigo 21 do Regulamento de 1933, por exemplo, estabelecia: "Serão assinados por advogados, inscritos nos quadros da Ordem, todas as petições iniciais e de recurso, articulados e arrazoados, competindo-lhes a sustentação oral em qualquer instância." 3.) restringiu a atuação dos rábulas, que foram incorporados à Ordem em condição subalterna. De acordo com o Estatuto de 1933, os provisionados seriam inscritos num quadro à parte dos advogados. Ademais, seriam completamente desprovidos de direitos políticos no âmbito da corporação, pois não poderiam "tomar parte nas discussões $e$ deliberações "68 Além disto, estabeleceu-se uma distinção pública entre os advogados e os práticos. Os primeiros gozavam do direito de usar vestes talares e sentar-se à direita dos juízes de primeira instância. Também podiam falar sentados nos tribunais. Já os rábulas deveriam, durante as sessões, sentar-se à esquerda dos juízes e falar em pé. ${ }^{69}$

\footnotetext{
${ }^{65}$ COELHO, Edmundo Campos, op. cit., p. 189-191.

${ }^{66}$ BONELLI, Maria da Gloria, op. cit., p. 38.

${ }^{67}$ Artigos 10 e 11 do Decreto n ${ }^{\circ} 22.478$, de 20 de fevereiro de 1933.

${ }^{68}$ Parágrafo único do artigo 12 do Decreto ${ }^{\circ} 22.478$, de 20 de fevereiro de 1933.

${ }^{69}$ Artigo 25 do Decreto no 22.478 , de 20 de fevereiro de 1933.
} 


\section{A criação da Ordem dos Advogados do Brasil (OAB)}

Com a Revolução de 1930, a Ordem dos Advogados do Brasil (OAB) foi finalmente criada, por meio de um decreto federal, em 18 de novembro de $1930 .{ }^{70} \mathrm{O}$ governo revolucionário delegou ao IAB a organização da nova entidade. André de Faria Pereira reclamou, ao menos em duas ocasiões, na década de 1950, a paternidade da lei que criou a Ordem. Segundo ele, na condição de procurador-geral do Distrito Federal foi incumbido pelo ministro da Justiça, Osvaldo Aranha, de redigir um decreto que reorganizasse a Corte de Apelação da capital da República. Conhecendo a antiga reivindicação dos advogados pela organização de sua corporação (já que ele próprio era membro do IAB), Pereira teria inserido no projeto encomendado o artigo que criava a OAB. ${ }^{71}$ Ao discursar em sessão do Conselho Federal da $\mathrm{OAB}$, por ocasião do $25^{\circ}$ aniversário de criação da Ordem, André de Faria Pereira, então conselheiro federal, explicitou a relação entre a criação da Ordem e o objetivo de expurgar a categoria profissional:

"Ninguém, melhor que eu (...) sentira a necessidade de moralização de classe dos advogados, notadamente quando exerci, pela primeira vez [antes da Revolução de 1930], o cargo de Procurador-Geral do Distrito Federal, na luta tremenda que travei contra os maus elementos da Justiça, da Polícia e da classe dos advogados e, depois, quando reintegrado [após a Revolução de 1930] (...) Aquele tempo não havia egresso das penitenciárias ou comerciante falido que não se julgasse com o direito de sobraçar uma pasta e afrontar o pretório no exercício da mais degradante rabulice. A consciência coletiva repelia os intrusos, mas seus malefícios desmoralizavam o ambiente a tal ponto que a função de advogado era suspeitada como de traficantes irresponsáveis. "72

\footnotetext{
${ }^{70}$ Artigo 17 do Decreto ${ }^{\circ}$ 19.408, de 18 de novembro de 1930.

${ }^{71}$ Arquivo do Conselho Federal da OAB (CF-OAB), Ata de sessão do Conselho Federal, 22/11/1955; VENÂNCIO FILHO, Alberto. Notícia histórica da OAB, 1930-1980. São Paulo: Conselho Federal da $\mathrm{OAB}, 1982$, p. 22-30.

${ }^{72}$ CF-OAB, Ata de sessão do Conselho Federal, 22/11/1955.
} 
Ainda que aceitemos a versão de André de Faria Pereira (que não foi contraditado, no Conselho Federal, nas ocasiões em que reivindicou a paternidade do decreto criador da $\mathrm{OAB}$ ), não há dúvidas de que uma parte da elite dos advogados se movimentou para obter do governo revolucionário a criação de sua corporação. A prova disso é que no dia 13 de novembro de 1930, o IAB, presidido por Levi Carneiro, debateu um projeto de lei elaborado por alguns de seus sócios que previa a criação da Ordem dos Advogados. Porém, admitiu Levi Carneiro mais tarde, a proposta do instituto chegou às mãos do ministro da Justiça depois da edição do decreto que criou a OAB. $^{73}$

Pouco depois de publicado o decreto que criara a OAB, Levi Carneiro, na qualidade de presidente do IAB, nomeou uma comissão encarregada de elaborar o regulamento da Ordem. Em 1931, o mesmo Levi Carneiro, já no cargo de consultorgeral da República, deu um parecer favorável ao projeto encaminhado pelo IAB - ao qual ele próprio havia oferecido sugestões. Em 14 de dezembro do mesmo ano, o governo aprovou, por meio do Decreto $\mathrm{n}^{\mathrm{o}}$ 20.784, o regulamento da OAB. Após algumas modificações foi consolidado pelo Decreto $\mathrm{n}^{\mathrm{o}} 22.478$, de 20 de fevereiro de $1933 .^{74}$

De filiação obrigatória a todos os advogados, a OAB foi concebida pela elite dos advogados instalada no IAB como um órgão paraestatal, porém autogerido, que recebia do Estado a função de fiscalizar o exercício da advocacia. $\mathrm{O}$ artigo $1^{\circ}$ do estatuto de 1933 definia a Ordem como "órgão de classe, defesa e disciplina da classe dos advogados em toda a República." $\mathrm{O}$ artigo $2^{\circ}$ definia a $\mathrm{OAB}$ como "serviço público federal". E o artigo $5^{\circ}$ estabelecia que os governos federal e estaduais deveriam prover a Ordem das instalações necessárias. É provável que a OAB tenha nascido com mais autonomia em relação ao Estado do que as outras instituições corporativistas criadas para as ocupações de nível superior no mesmo período. ${ }^{75}$

\footnotetext{
${ }^{73}$ VENÂNCIO FILHO, Alberto. Notícia histórica da OAB, 1930-1980, op. cit., p. 21-22.

${ }^{74}$ Ibidem, p. 21-36.

${ }^{75}$ BONELLI, Maria da Gloria, op. cit., p. 57-58. LESSA, Renato; LINHARES, Leila, op. cit., p. 22.
} 
Contudo, houve resistências à atuação da $\mathrm{OAB}$ mesmo no interior da elite dos advogados, o que sugere que a iniciativa de criação da Ordem tenha sido uma démarche de uma fração da elite da categoria profissional - não necessariamente majoritária -, que comandava o IAB e era vinculada aos revolucionários de 1930. Movidos por suas convicções liberais, alguns advogados de elite viam na ação da Ordem - cujas atribuições punitivas eram destacadas - uma insuportável restrição à sua liberdade profissional. ${ }^{76}$ Eugênio Haddock Lobo, membro do Conselho da OAB da Guanabara desde 1969 e presidente da OAB do estado do Rio de Janeiro entre 1977 e 1979, em depoimento a Renato Lessa e a Leila Linhares conta:

“(...) porque eu me recordo de que, quando estudava Direito na faculdade, os velhos advogados de então entendiam que a Ordem devia ser rejeitada, que não se devia participar da Ordem, das eleições, porque a Ordem era um órgão de fiscalização e punição. Tinha uma posição muito sectária de reação contra a $\operatorname{Ordem}(\ldots) ., 77$

Celso Fontenelle, membro do Conselho da OAB do Distrito Federal desde 1948, narrou, em depoimento concedido no âmbito do mesmo projeto, a resistência de seu pai, Jorge Dyott Fontenelle, em se filiar a OAB. Resistente de início, ele terminou cooptado pela fração da elite profissional que implantou a Ordem, pois foi presidente do Conselho da OAB do Distrito Federal entre 1951 e 1953 e conselheiro federal entre 1951 e 1952:

"Então, papai, num determinado momento, tinha que se inscrever na Ordem dos Advogados. E ele se recusou. Ele entendeu que era um captis

\footnotetext{
76 "É de se imaginar as resistências que advogados já consagrados, e de persuasão liberal, puderam opor ao enquadramento implicado da existência e na idéia da Ordem. Na percepção desses grandes advogados sua identidade já estava constituída, e dependia exclusivamente de seus desempenhos individuais, das linhagens das quais descendiam ou da influência de seus mestres. O que a idéia de Ordem introduzia era a novidade de um processo de atribuição de identidades pela via institucional." LESSA, Renato; LINHARES, Leila, op. cit., p. 23.

${ }^{77}$ LESSA, Renato; LINHARES, Leila, op. cit., p. 22-23.
} 
diminutio. Era uma restrição à liberdade dele. (...) Em determinado dia, chegaram no escritório dele Justo de Morais, Levi Carneiro, Fernando Willermont, que eram os grandes nomes da profissão, dizendo: Fontenelle, à uma hora encerra a inscrição hoje, para você poder...você ainda não se inscreveu. Tanto que o número do papai, que poderia ser 1 ou 2, naquela época era 105 $(\ldots)^{\prime \prime}$

"O papai achava que estava contrariando a liberdade dele, ele ser obrigado. Ele que se formou em bacharel, ele ter que se inscrever numa entidade para poder exercer uma profissão que ele ganhou (...) Mas depois naturalmente ele foi Conselheiro várias vezes. Foi Presidente da Ordem (...),"78

As reações surgiram, também, na base da categoria profissional. Um grande número de rábulas gaúchos solicitou ao Governo Provisório o direito de continuarem a exercer o ofício, apesar de não se enquadrarem nos requisitos estabelecidos pela OAB. O governo, pelo Decreto $\mathrm{n}^{\circ} 21.592$, de 1932, concordou com o pleito dos práticos, porém limitou sua atuação profissional ao Rio Grande do Sul e determinou que se matriculassem no Tribunal Superior do estado e na seção gaúcha da OAB. ${ }^{79}$

$A$ criação da $\mathrm{OAB}$ insere-se num contexto mais amplo, que é o da reorganização do Estado brasileiro em moldes corporativistas ${ }^{80} \mathrm{O}$ mecanismo corporativista foi

\footnotetext{
${ }^{78}$ Ibidem, p. 23.

${ }^{79}$ GUIMARÃES, Lúcia Maria Paschoal; BESSONE, Tânia. História da Ordem dos Advogados do Brasil. Criação, primeiros percursos e desafios (1930-1945). Brasília: OAB, 2003, v. 4, p. 42.

${ }^{80}$ VIANNA, Luiz Werneck. Os intelectuais da tradição e a modernidade: os juristas-políticos da OAB, op. cit., p. 99-101, 109. BONELLI, Maria da Glória, op. cit., p. 56. Para Aurélio Wander Bastos, a criação da $\mathrm{OAB}$ insere-se no quadro de um projeto da elite dos advogados contra as oligarquias e o patrimonialismo: "Neste contexto, voltamos a insistir, muitas das lideranças intelectuais, dentre elas, a elite dos advogados do IOAB, incluindo seu presidente Levi Carneiro, confrontaram-se historicamente com a contumaz resistência dos oligarcas e de sua representação política no combate à criação da $O A B$, que, efetivamente, representava um projeto de desconstrução do patrimonialismo oligárquico, em muitas ocasiões travestido de ilustrado bacharelismo." BASTOS, Aurélio Wander, op. cit., p. 100. Embora interessante, a tese não é suficientemente examinado pelo autor e, menos ainda, comprovada. Ademais, como sabemos, os quadros políticos do liberalismo oligárquico eram, em boa medida, bacharéis em Direito. Em outro trecho do seu trabalho, Bastos reconhece a cumplicidade dos bacharéis com as oligarquias: "O Instituto dos Advogados não se envolveu diretamente com estes movimentos sociais corporativistas que pleiteavam a representação parlamentar profissional e classista, até mesmo pelas origens liberais de seus compromissos e pelos profundos vínculos dos advogados com o velho $e$ decadente estado oligárquico." (grifos meus). BASTOS, Aurélio Wander, op. cit., p. 105-106.
} 
imposto aos trabalhadores urbanos com vistas ao controle político. O reverso da coerção era o benefício de uma política social, que incluía uma legislação trabalhista. ${ }^{81}$ No caso das profissões liberais, a regulamentação profissional de corte corporativista foi antes uma reivindicação de suas elites que uma imposição governamental, com a qual almejavam conquistar o monopólio do mercado de serviços profissionais e a autonomia corporativa. $^{82}$

O primeiro governo Vargas foi pródigo na legislação de regulamentação profissional. Em 1931, baixou decreto regulando o exercício da profissão de farmacêutico (Decreto $\mathrm{n}^{\circ}$ 20.377, de 8/9/1931). Em 1933, regulou o exercício da profissão de agrônomo (Decreto n ${ }^{\circ}$ 23.196, de 12/10/1933). No mesmo ano, regulou também o exercício da profissão de engenheiro, arquiteto e agrimensor (Decreto $\mathrm{n}^{\circ}$ 23.569, de 11/12/1933). No ano seguinte, foi a vez da profissão de químico (Decreto $\mathrm{n}^{\circ}$ 24.693, de 12/7/1934). Finalmente, em 1945, por meio do Decreto-lei n ${ }^{\circ} 7.955$ (13/9/1945), instituiu os conselhos de Medicina. ${ }^{83}$ A peça fundamental da estrutura corporativista das profissões de nível superior eram os conselhos nacionais e regionais. Cabia aos conselhos estabelecer o campo das atividades privativas das profissões. Ademais, o ingresso na profissão devia atender a certas exigências, como o pagamento de contribuição anual, o registro no respectivo conselho e, sobretudo, a posse de um

\footnotetext{
${ }^{81}$ De acordo com Angela de Castro Gomes, "foi praticamente a partir de 1942-3 que o Estado brasileiro se esforçou para implementar seu projeto de organização sindical corporativista. Este, até então, funcionava apenas como orientação legal e como uma ficção organizacional. (...) O sindicalismo corporativista, desta forma, iria ser realmente implementado não no momento autoritário por excelência do Estado Novo, mas no periodo de 'transição' do pós-42, quando a questão da mobilização de apoios sociais tornou-se uma necessidade inadiável ante a própria transformação do regime." GOMES, Angela Maria de Castro. A invenção do trabalhismo. Rio de Janeiro: Relume Dumará, 1994, p. 237-238. Depreende-se, portanto, que os advogados foram incorporados de fato à estrutura corporativista vários anos antes que os trabalhadores urbanos.

${ }^{82}$ VIANNA, Luiz Werneck; VIANNA, Maria Lucia Teixeira Werneck. A OAB como intelectual coletivo: 1964-1980. Rio de Janeiro: IUPERJ, 1984. 2v. (datilogr.), p. 108-109. VIANNA, Luiz Werneck. Os intelectuais da tradição e a modernidade: os juristas-políticos da OAB, op. cit., p. 99. MICELI, Sergio. Intelectuais e classe dirigente no Brasil (1920-45), op. cit., p. 204-205. "De fato, a regulação profissional no pós-30 moldou para as profissóes de nível superior o estatuto de uma verdadeira aristocracia ocupacional com seus monopólios, privilégios e mecanismos de representação de interesses corporativos." COELHO, Edmundo Campos, op. cit., p. 285.

${ }^{83}$ COELHO, Edmundo Campos, op. cit., p. 28.
} 
diploma superior - o que, evidentemente, não era exigido dos práticos, que, com restrições, foram admitidos na $\mathrm{OAB} .^{84}$

É irônico que a organização corporativista tenha reforçado a cultura jurídica tradicional, de corte liberal, comungada pela elite dos advogados, mas submetida a duros questionamentos durante a Primeira República. A OAB será estruturada para defender esta cultura jurídica e disseminar os valores profissionais partilhados pela elite dos advogados. ${ }^{85}$ Assim, a OAB veiculará a cultura profissional baseada na noção de "sacerdócio", malgrado, como nota Werneck Vianna, escrevendo em meados da década de 1980, “a expansão notável da sociedade mercantil nas últimas décadas." advocacia era, para a elite profissional, uma função de interesse público. $\mathrm{Na}$ sua concepção, o ofício que exerciam era incompatível com a lógica mercantil. Ao discursar para os presidentes estaduais da OAB durante a $2^{\text {a }}$ Conferência Nacional da Ordem, Rui de Azevedo Sodré, integrante da diretoria da seção paulista da corporação, resumiu a representação que a elite dos advogados tinha de sua profissão:

“A advocacia é um 'munus' público e não uma atividade comercial. A exploração comercial da advocacia, mercantilizando-a, deve sofrer a repulsa de todos os advogados, conscientes da sua missão social."

"A advocacia e a atividade comercial são profissões com finalidades antagônicas."

“(...) O advogado é um produtor de bens culturais. $O$ nosso objetivo não é negociar com a justiça, visando um lucro. O nosso trabalho deve ser remunerado, mas não pode ser inspirado por um espírito de mercantilismo. ${ }^{, 87}$

Instrumento central de adequação dos advogados à cultura profissional dominante na direção da OAB, o Código de Ética Profissional passou a vigorar em

\footnotetext{
${ }^{84}$ COELHO, Edmundo Campos, op. cit., p. 28-29.

${ }^{85}$ VIANNA, Luiz Werneck. Os intelectuais da tradição e a modernidade: os juristas-políticos da OAB, op. cit., p. 103, 107.

${ }^{86}$ Ibidem, p. 109.

${ }^{87}$ Anais da $2^{a}$ Conferência Nacional da Ordem dos Advogados do Brasil. São Paulo: Revista dos Tribunais, 1961, p. 12.
} 
novembro de 1934 - atravessando todo o período democrático. Levi Carneiro participou ativamente de sua elaboração e foi um dos seus signatários, assim como vários advogados que representavam as seções estaduais da Ordem e que seriam membros ou mesmo presidentes do Conselho Federal no período democrático, como Atílio Vivacqua, Haroldo Valadão, Targino Ribeiro, Joaquim Amazonas, Leopoldo Cunha Melo, Demóstenes Madureira de Pinho, Sanelva de Rohan e João Vilasboas. Pedro Aleixo, como representante mineiro, assinou, igualmente, o documento. ${ }^{88}$

O Conselho Federal foi instalado apenas em 1933. Até então, a direção da OAB coubera ao IAB (entre 1930 e 1932) e à seção do Distrito Federal (entre 1932 e 1933). No seu primeiro decênio, o órgão recolheu-se à esfera corporativa e dedicou-se à organização da Ordem. Neste período inicial, o Conselho Federal praticamente não se pronunciou sobre o rompimento da ordem jurídica imposta por Vargas, nem quanto aos instrumentos autoritários implementados pelo governo, especialmente depois do golpe do Estado Novo, em 1937. ${ }^{89}$ É verdade que a Ordem nomeou defensores para presos políticos julgados pelo Tribunal de Segurança Nacional. Ainda em meados da década de 1930, Heráclito Sobral Pinto, por solicitação da OAB, assumiu a defesa de Luís Carlos Prestes e Harry Berger, dois dos principais líderes da insurreição comunista de $1935 .{ }^{90}$ Entretanto, o que prevalecia no Conselho Federal era uma postura cautelosa em relação ao Executivo, do qual dependia para a sua consolidação institucional.

Em julho de 1939, depois da aprovação do projeto do Instituto de Pensões e Aposentadorias dos Advogados, o secretário-geral da OAB, Atílio Vivácqua, afirmou, em sessão do Conselho Federal, que, a partir daquele dia, a Ordem devia ao governo dois favores: a sua própria criação, em 1930, e o Instituto de Pensões ${ }^{91}$. No ano anterior, o presidente da $\mathrm{OAB}$, Fernando de Melo Viana, entabulara conversações com o governo

\footnotetext{
${ }^{88}$ VENÂNCIO FILHO, Alberto. Notícia histórica da OAB, 1930-1980, op. cit., p. 41. GUIMARÃES, Lúcia Maria Paschoal; BESSONE, Tânia. História da Ordem dos Advogados do Brasil. Criação, primeiros percursos e desafios (1930-1945), op. cit., p. 51-54.

${ }^{89}$ VENÂNCIO FILHO, Alberto. Notícia histórica da OAB, 1930-1980, op. cit., p. 30-57. GUIMARÃES, Lúcia Maria Paschoal; BESSONE, Tânia. História da Ordem dos Advogados do Brasil. Criação, primeiros percursos e desafios (1930-1945), op. cit., p. 101-102.

${ }^{90}$ VENÂNCIO FILHO, Alberto. Notícia histórica da OAB, op. cit., p. 57-60.

${ }^{91}$ CF-OAB, Ata de sessão do Conselho Federal, 11/7/1939.
} 
para a obtenção de novas instalações para o Conselho Federal. Relatando o seu encontro com o ministro da Justiça, o presidente afirmou que o primeiro demonstrara

“a maior boa vontade para a concessão da verba necessária para este fim [a nova sede do Conselho Federal]. Foi-lhe comunicado ainda, terem sido tomadas providências para que, no futuro Palácio da Justiça, sejam reservadas dependências para a Ordem dos Advogados. "92

Em maio de 1943, o Conselho Federal aplaudiu a criação, pelo governo, da Caixa dos Advogados e a promessa de Vargas de conceder um terreno para as novas instalações da $\mathrm{OAB} .^{93}$

A OAB nasceu, portanto, sob o signo do apoio oficial. Na solenidade de instalação do Conselho Federal da Ordem, em 9 de março de 1933, estiveram presentes, além do ministro da Fazenda, Osvaldo Aranha, representantes dos ministros da Justiça, do Trabalho, da Marinha e das Relações Exteriores e dos interventores do Pará, Piauí, Pernambuco, Alagoas, Sergipe, Bahia, Espírito Santo, Minas Gerais, Rio Grande do Sul, Goiás e Paraná. Igualmente, compareceram à cerimônia magistrados e o presidente da Corte de Apelação do Distrito Federal. ${ }^{94}$ A Ordem apenas procurou distanciar-se do Estado (ou, mais propriamente, do governo) nos últimos anos do Estado Novo. A partir de então, perseguiu uma autonomia que lhe daria feições antes de uma entidade da sociedade civil que de um organismo semi-estatal.

Alguns estudiosos sugerem que os bacharéis que acumulavam a direção da OAB e do Instituto dos Advogados, procurando preservar a Ordem de represálias governamentais, canalizaram suas críticas ao governo Vargas para o Instituto prestigiado por sua trajetória secular e menos dependente do Estado. Durante o Estado

\footnotetext{
${ }^{92}$ CF-OAB, Ata de sessão do Conselho Federal, 18/10/1938.

${ }^{93}$ VENÂNCIO FILHO, Alberto. Notícia histórica da OAB, op. cit., p. 63.

${ }^{94}$ GUIMARÃES, Lúcia Maria Paschoal; BESSONE, Tânia. História da Ordem dos Advogados do Brasil. Criação, primeiros percursos e desafios (1930-1945), op. cit., p. 43.
} 
Novo, a função crítica teria sido assumida pela seção da OAB do Distrito Federal. ${ }^{95}$ De fato, há comprovação documental de que tanto o Instituto quanto a seção carioca da Ordem fizeram pronunciamentos e tomaram iniciativas que afrontaram o governo Vargas. ${ }^{96}$ Contudo, como complemento a esta explicação, há que se investigar em que medida a proximidade de Levi Carneiro com Getúlio Vargas inibiu manifestações oposicionistas no seio do Conselho Federal durante sua gestão.

Levi Carneiro presidiu a OAB entre 1933 e 1938. Presidente do IAB entre 1928 e 1931, foi também diretor e vice-presidente da Caixa Econômica do Rio de Janeiro, entre 1927 e 1928. Vitoriosa a Revolução de 1930, foi convidado a assumir o ministério da Justiça. Declinou do convite, mas aceitou a nomeação para o cargo de consultorgeral da República, que ocupou de novembro de 1930 a julho de 1934. Como se nota, Carneiro acumulou este cargo no Governo Provisório, primeiramente, com a presidência do IAB e, depois, com a da OAB. Em 1933, foi eleito deputado classista, como representante dos profissionais liberais, à Assembléia Nacional Constituinte. No ano seguinte, elegeu-se deputado federal pelo estado do Rio de Janeiro pelo Partido Popular Radical (PPR). Exerceu seu mandato até 1937, quando o parlamento foi fechado pelo Estado Novo. O PPR foi fundado por políticos fluminenses que haviam apoiado a candidatura derrotada de Nilo Peçanha à presidência da República, em 1922. Entre 1929 e 1930, estes "nilistas" apoiaram a campanha da Aliança Liberal. Um dos chefes do PPR era o futuro bâtonnier Raul Fernandes. Carneiro também acumulou a presidência da Ordem com o cargo de deputado. Em meados de 1936, Levi Carneiro ingressou na Academia Brasileira de Letras (ABL). Finalmente, entre 1938 e 1940, foi professor de Direito Comercial na Faculdade Nacional de Direito, no Distrito Federal. ${ }^{97}$

O sucessor de Levi Carneiro na OAB, Fernando de Melo Viana, dirigiu a Ordem até 1944. Filho de um fazendeiro e comerciante, Melo Viana foi um político mineiro

\footnotetext{
${ }^{95}$ GUIMARÃES, Lúcia Maria Paschoal; BESSONE, Tânia. História da Ordem dos Advogados do Brasil. Criação, primeiros percursos e desafios (1930-1945), op. cit., p. 16 e 126. VENÂNCIO FILHO, Alberto. Notícia histórica da $O A B$, op. cit., p. 57.

${ }^{96}$ Cf. GUIMARÃES, Lúcia Maria Paschoal; BESSONE, Tânia. História da Ordem dos Advogados do Brasil. Criação, primeiros percursos e desafios (1930-1945), op. cit., p. 55-127.

${ }^{97}$ PECHMAN, Robert. CARNEIRO, Levi. In: ABREU, Alzira Alves de et alli. (coord.). Dicionário histórico-biográfico brasileiro, pós-1930. Rio de Janeiro: CPDOC/FGV, 2002.
} 
eminente na Primeira República, quando atuou como secretário do interior e foi governador do seu estado natal. Antes, exercera os cargos de promotor e juiz. Vicepresidente da República, foi deposto, com Washington Luís, em 1930. Ao voltar do exílio na Europa, em 1932, abriu um escritório de advocacia em Belo Horizonte. Mais tarde, nomeado advogado de Minas Gerais no Rio de Janeiro, mudou-se para a capital da República. Em 1945, foi eleito senador pelo Partido Social Democrático (PSD). Na condição de seu presidente, tomou parte dos trabalhos da Assembléia Nacional Constituinte de 1946. Também presidiu a Companhia de Seguros Colúmbia e várias instituições bancárias. ${ }^{98}$

\section{Organização e funcionamento da OAB}

No período estudado neste trabalho, a estrutura, as atribuições e o funcionamento da OAB eram determinados pelo estatuto de 1933 (Decreto no 22.478, de 20 de fevereiro de 1933) e, depois, pelo de 1963 (Lei n 4.215, de 27 de abril de 1963). Além disto, o funcionamento, a composição e as atribuições do Conselho Federal eram também estabelecidos e detalhados pelo Regimento Interno de 1933, substituído, sucessivamente, pelos de 1952 e de 1963.

O Conselho Federal era o organismo máximo da OAB. Nos estados, no Território do Acre e no Distrito Federal, funcionavam os Conselhos Seccionais, que deviam prestar contas ao Conselho Federal, embora tivessem autonomia administrativa. ${ }^{99}$ Com exceção do Conselho Seccional do Distrito Federal em Brasília (organizada em 1960), todas as outras 22 seções estaduais da OAB foram criadas entre 1932 e $1933 .{ }^{100}$ Nos municípios, podiam ser organizadas subseções da Ordem. ${ }^{101}$ Nas eleições da Ordem, de acordo com o Estatuto de 1933, o voto era obrigatório aos afiliados. $^{102}$

\footnotetext{
${ }^{98}$ FARIA, Helena. VIANA, Melo. In: ABREU, Alzira Alves de et alli. (coord.), op. cit.

${ }^{99}$ Artigo $3^{\circ}$ do Decreto $n^{\circ} 22.478$, de 20 de fevereiro de 1933; artigo $4^{\circ}$ da Lei ${ }^{\circ} 4.215$, de 27 de abril de 1963.

${ }^{100}$ Boletim da Ordem dos Advogados do Brasil, Rio de Janeiro, ano 28, número 28, 1962, p. 13.

${ }^{101}$ Parágrafos $2^{\circ}$ ao $5^{\circ}$ do Artigo $3^{\circ}$ do Decreto $\mathrm{n}^{\circ} 22.478$, de 20 de fevereiro de 1933; parágrafos $3^{\circ}$ e $4^{\circ}$ do artigo $4^{\circ}$ da Lei $n^{\circ} 4.215$, de 27 de abril de 1963.

${ }^{102}$ Artigo 62 do Decreto n ${ }^{\circ} 22.478$, de 20 de fevereiro de 1933.
} 
Os Conselhos Seccionais indicavam os seus representantes no Conselho Federal. Os membros do Conselho Federal elegiam o seu presidente e secretário-geral e, a partir de 1963, também o vice-presidente e o tesoureiro (cargos criados pelo Estatuto de 1963). Cada delegação estadual tinha direito a um voto nas deliberações do Conselho Federal. ${ }^{103}$ Até 1963 , o presidente e o secretário-geral tinham, cada qual, direito a voto. Com o novo estatuto, os membros da diretoria perderam o direito de voto individual e passaram a participar das deliberações como membros de suas delegações; o presidente, por sua vez, teve seu direito de voto restringido, passando a votar apenas em caso de empate nas votações. Por outro lado, o Estatuto de 1963 tornou os ex-presidentes da OAB membros natos do Conselho Federal, com direito a voz e voto. ${ }^{104}$ Esta medida, como se pode perceber, representou um reforço na continuidade institucional do órgão. O Estatuto de 1933 estabelecia que o presidente do Conselho Federal deveria ser escolhido entre os presidentes dos Conselhos Seccionais; o Estatuto de 1963 aboliu esta exigência - na realidade nem sempre respeitada. Os outros membros da diretoria deveriam provir dos próprios quadros do Conselho Federal. ${ }^{105}$ - outra medida que favorecia a continuidade institucional e, sobretudo, o caráter relativamente fechado do organismo. As eleições para a diretoria do Conselho Federal ocorriam a cada dois anos, nos meses de julho ou agosto. Os Conselhos Seccionais indicavam os seus representantes anualmente até 1963, em geral, no início de cada ano. A partir de setembro de 1963, a indicação passou a ser bienal. ${ }^{106}$

\footnotetext{
${ }^{103}$ Artigos 83, 84 e 88 do Decreto ${ }^{\circ} 22.478$, de 20 de fevereiro de 1933; artigo $^{\circ}$ da Lei $n^{\circ} 4.215$, de 27 de abril de 1963.

${ }^{104}$ Parágrafo $2^{\circ}$ do artigo 89 do Decreto $\mathrm{n}^{\circ} 22.478$, de 20 de fevereiro de 1933; parágrafo $2^{\circ}$ do artigo $16 \mathrm{e}$ parágrafo $1^{\circ}$ do artigo 13 da Lei $n^{\circ} 4.215$, de 27 de abril de 1963 .

${ }_{105}$ Artigo 88 do Decreto $n^{\circ} 22.478$, de 20 de fevereiro de 1933; parágrafos $1^{\circ}$ e $2^{\circ}$ do artigo $7^{\circ}$ da Lei $n^{\circ}$ 4.215, de 27 de abril de 1963.

${ }^{106}$ Artigo $2^{\circ}$ do Regimento Interno do Conselho Federal da OAB, 16/12/1952; parágrafo $3^{\circ}$ do artigo $1^{\circ}$ do Regimento Interno do Conselho Federal da OAB, 17/9/1963.
} 


\section{CAPÍTULO I: ESTADO NOVO E GOVERNO DUTRA}

\section{1.) A frente oposicionista}

A partir de 1943, vários setores da sociedade civil organizaram-se para combater o Estado Novo. Como o parlamento fora fechado, os partidos políticos dissolvidos e vigorava a censura à imprensa, as entidades civis apresentaram-se como o canal natural para a ação da oposição. Entre estas encontravam-se a União Nacional dos Estudantes (UNE), a Associação Brasileira de Escritores, a União Democrática Socialista, a Liga de Defesa Nacional, a Sociedade Amigos da América, a Legião Cinco de Julho e a União de Trabalhadores Intelectuais. Malgrado suas distintas colorações ideológicas (que variavam do liberalismo conservador ao socialismo), estas entidades comungavam entre si o objetivo de pôr termo à ditadura estadonovista. No início de 1945, a frente oposicionista ganhou um partido político, a União Democrática Nacional (UDN), e um candidato à presidência da República, o brigadeiro Eduardo Gomes. ${ }^{107}$

Observe-se que a mobilização oposicionista era sustentada por setores das classes médias e dominantes. As organizações dos trabalhadores urbanos, destacadamente os sindicatos, alinhadas ao trabalhismo ou ao Partido Comunista do Brasil (PCB), permaneceram distantes da ação da oposição.

Apesar da presença de socialistas (como Paulo Emílio Salles Gomes), de comunistas que divergiam da linha oficial do PCB (como Caio Prado Júnior) e de dissidentes do Estado Novo (como Osvaldo Aranha) na formação da UDN, a espinha dorsal da coalizão oposicionista era o grupo liberal. Certidão de nascimento da oposição liberal ao Estado Novo, o Manifesto dos Mineiros, divulgado em 1943, revelava a composição elitista do grupo e o conservadorismo do seu programa político. Reivindicando a tradição liberal brasileira, o documento fazia a defesa das liberdades civis, mas se calava quanto a outros temas de interesse popular, como a ampliação da participação política e a liberdade sindical. Entre os 92 signatários do manifesto,

107 BENEVIDES, Maria Victoria de Mesquita. A UDN e o udenismo. Ambigüidades do liberalismo brasileiro (1945 - 1965). Rio de Janeiro: Paz e Terra, 1981, p. 33-34, 37-38, 45. 
destacavam-se os bacharéis, que, em geral, trabalhavam como consultores jurídicos ou diretores de bancos. ${ }^{108}$ Este é um aspecto que merece ser ressaltado. A oposição liberal recrutará largamente os seus membros no meio jurídico. Prova disto é que, dentre os signatários da lista de fundação da UDN, metade eram advogados. ${ }^{109}$

A idéia de elaboração do Manifesto dos Mineiros nasceu com a saída de integrantes da oposição liberal do $2^{\circ}$ Congresso Jurídico Nacional, realizado em agosto de 1943, em comemoração ao centenário do IAB. ${ }^{110}$ Em protesto contra a recusa do ministro da Justiça, Marcondes Filho, presidente do encontro, de permitir o debate de teses que criticavam o Estado Novo, alguns bacharéis abandonaram o evento. Dentre eles estavam André de Faria Pereira, Adauto Lúcio Cardoso, Adolfo Bergamini e Pedro Aleixo, todos vinculados à OAB. A maioria deles fundaria a UDN, em 1945. O protesto dos bacharéis liberais no $2^{\circ}$ Congresso Jurídico foi tema de debate no Conselho Federal, recebendo o apoio de conselheiros como Odilon Braga (ele próprio um integrante da oposição liberal) e Américo Mendes de Oliveira Castro, que propôs um voto de louvor pela atitude. ${ }^{111}$

\section{2.) O engajamento do Conselho Federal no combate ao Estado Novo}

Ainda que seja necessário aprofundar o exame da atuação do Conselho Federal da OAB ao longo do Estado Novo (o que não faz parte do escopo deste trabalho), podese afirmar que o organismo engajou-se na oposição ao regime apenas em 1944. O ingresso do Conselho Federal da $\mathrm{OAB}$ na luta contra o Estado Novo coincidiu com a ascensão à direção do órgão de um grupo de ilustres advogados, integrantes do núcleo de bacharéis liberais, que participariam, no ano seguinte, da criação da UDN. Afastados da política partidária desde a implantação do Estado Novo, estes advogados

\footnotetext{
${ }^{108}$ BENEVIDES, Maria Victoria de Mesquita, op. cit., p. 34-36.

${ }^{109}$ BENEVIDES, Maria Victoria de Mesquita, op. cit., p. 28.

110 BENEVIDES, Maria Victoria de Mesquita, op. cit., p. 35. DULLES, John W. F. Sobral Pinto: a consciência do Brasil. Rio de Janeiro: Nova Fronteira, 2001, p. 237. VENÂNCIO FILHO, Alberto. Notícia histórica da OAB, op. cit., p. 63. CARONE, Edgard. O Estado Novo (1937-1945). Rio de Janeiro: Difel, 1977, p. 304-306.

111 GUIMARÃES, Lúcia Maria Paschoal; BESSONE, Tânia. História da Ordem dos Advogados do Brasil. Criação, primeiros percursos e desafios (1930-1945), op. cit., p. 115.
} 
transformaram o Conselho Federal da entidade em trincheira de combate a Vargas. Num golpe branco, negaram a possibilidade de mais uma reeleição a Fernando de Mello Viana e alçaram Raul Fernandes ao posto de bâtonnier. ${ }^{112}$ Membro da oligarquia cafeeira do Estado do Rio, Fernandes - que se tornaria figura importante na UDN - era diplomata e político de projeção nacional. ${ }^{113} \mathrm{O}$ principal articulador de sua candidatura foi o conselheiro federal Dario de Almeida Magalhães, pertencente à oligarquia mineira destronada pela Revolução de 1930 e um dos responsáveis pelo Manifesto dos Mineiros. Magalhães também ingressaria na UDN. ${ }^{114}$ Augusto Pinto Lima foi outra figura central da OAB durante os estertores do Estado Novo. Presidente da Seção do Distrito Federal da entidade, ele assumiu frequentemente a direção do Conselho Federal, em virtude das ausências de Raul Fernandes. Alinhado ao grupo liberal, Pinto Lima foi um dos oradores da sessão de fundação da UDN, em abril de 1945, ocasião em que discursou como representante do Conselho do Distrito Federal da OAB: "não podemos votar com a Carta de 37. Não queremos eleições prostituídas e conspurcadas, como obséquio, como graça do Sr. Getúlio Vargas, através do Sr. Agamenon, esse bandoleiro do Direito". 115

A eleição de Raul Fernandes provou que, mesmo num contexto adverso, os bacharéis liberais mantinham-se politicamente dominantes no interior da categoria profissional. No mesmo período, eles dirigiam, igualmente, a seção do Distrito Federal da $\mathrm{OAB}$ e o IAB, cujos presidentes eram, respectivamente, Pinto Lima e Haroldo Valadão. Outro argumento a reforçar a tese da hegemonia do grupo liberal sobre a elite dos bacharéis estadonovistas é a filiação partidária dos integrantes do Conselho Federal da Ordem em 1945. Neste ano, ao menos quatro conselheiros federais eram filiados ao PSD: Romualdo Crepory, Elizabeto Carvalho (ambos pertencentes à delegação do Maranhão), Arino de Sousa Matos (representante do Rio de Janeiro) e Pedro Vergara (representante do Rio Grande do Sul). No entanto, com exceção de Romualdo Crepory,

\footnotetext{
${ }^{112}$ VENÂNCIO FILHO, Alberto. Notícia histórica da OAB, op. cit., p. 67.

${ }^{113}$ Cf. CARVALHO, Antônio Gontijo de. Raul Fernandes, um servidor do Brasil. Rio de Janeiro: Agir, 1956.

${ }^{114}$ MICELI, Sergio. Carne e osso da elite política brasileira pós-1930, op. cit., p. 581-582. BENEVIDES, Maria Victoria, op. cit., p. 29, 37.

${ }^{115}$ BENEVIDES, Maria Victoria de Mesquita, op. cit., p. 25.
} 
estes bacharéis participaram de apenas uma dentre as 39 sessões do Conselho Federal realizadas naquele ano. Crepory, por sua vez, esteve presente a quase um terço das sessões. Por outro lado, ao menos nove conselheiros federais em 1945 eram filiados à UDN: Adauto Lúcio Cardoso, Dario de Almeida Magalhães, José Augusto de Bezerra Medeiros, José Ferreira de Sousa, Oscar Stevenson, Osvaldo Trigueiro, Raul Fernandes, Nelson Carneiro e Antônio Carvalho Guimarães. Estes udenistas estiveram muito mais presentes que os pessedistas nas sessões do Conselho Federal de $1945 .{ }^{116}$

A presença maior da UDN (o partido, por excelência, dos bacharéis liberais) em relação ao PSD (a agremiação da elite estadonovista) no seio do Conselho Federal sugere uma relação de força, no final do Estado Novo, também favorável aos liberais no conjunto dos conselhos seccionais da Ordem, que determinavam, na realidade, a composição do órgão máximo da $\mathrm{OAB}$, ao nomearem os membros da delegações estaduais.

A militância antiestadonovista dos bacharéis liberais não se limitava ao Conselho Federal da Ordem; ela espraiava-se por outras instâncias da sociedade civil, como os jornais oposicionistas e a UDN. Todavia, mesmo depois que os partidos políticos foram reorganizados e a censura à imprensa arrefecida, a atuação oposicionista do Conselho Federal permaneceu importante no cenário político nacional, graças ao caráter da $\mathrm{OAB}$ como organismo representativo de uma categoria profissional de grande prestígio social e tradição de participação política. ${ }^{117}$

Com o acirramento dos embates entre Vargas e a oposição, alguns membros do Conselho Federal passaram a ser diretamente atingidos pela repressão política. Assim, em 6 de junho de 1944, o conselheiro federal da Ordem, e membro da oposição liberal, Adolfo Bergamini comunicou ao Conselho Federal que, convidado a proferir uma conferência no Instituto dos Advogados da Bahia, fora agredido pela polícia baiana.

\footnotetext{
${ }^{116}$ Estes dados foram obtidos nas atas de reuniões do Conselho Federal da OAB em 1945 e nos repertórios biográficos consultados.

${ }^{117} \mathrm{Na}$ moção contra o queremismo aprovada pelo Conselho Federal, o organismo reconhecia integrar uma frente política: "A coalizão das forças preservadoras do Direito e da ordem jurídica, bem superiores às meras fórmulas e aparências da legalidade, impediu, porém que esse subversivo propósito [o adiamento das eleições presidenciais] fosse então atingido." CF-OAB, Ata de sessão do Conselho Federal, 18/9/1945.
} 
Pronunciando-se sobre o ocorrido, o conselheiro federal Dario de Almeida Magalhães sublinhava que:

"o agravo de que fora vitima o representante do Conselho do Distrito Federal [Bergamini] não envolvia apenas a sua pessoa, mas toda a classe dos advogados, porque realizar trabalhos de caráter doutrinário fazia parte da função do advogado, tal como regido pelo Regulamento da Ordem e pelo Código de Ética Profissional, de forma que o constrangimento de que fora alvo representava uma violência ao próprio desempenho dos deveres que incumbe à classe dos advogados. "118

Em seguida, ele formulou uma proposta - unanimemente aprovada pelo Conselho - para que fossem encaminhados protestos contra a violência policial de que Bergamini fora vítima ao presidente da República, ao ministro da Justiça e ao interventor federal baiano. ${ }^{119}$

Em episódios assemelhados ao que aconteceu na Bahia, recorrentes no ano de 1944, o Conselho Federal repetiu o argumento apresentado por Dario Magalhães: o governo violentava as prerrogativas profissionais dos advogados. Até o início de 1945, esta será a arma com a qual a Ordem atacará o governo. Em meados de dezembro de 1944, a polícia do Distrito Federal ocupou e revistou o escritório do conselheiro federal Evandro Lins e Silva, que participaria da fundação da UDN, na condição de integrante da Esquerda Democrática. Em sessão do Conselho do Distrito Federal da OAB, o advogado mineiro Sobral Pinto pediu medidas enérgicas contra o fato, por se tratar de violação do segredo profissional, "sagrado em todos os tempos, em todos os povos".. ${ }^{120}$

A mobilização do Conselho Federal pela defesa dos bacharéis liberais atingidos pela repressão do Estado Novo atingiu o seu ápice com a prisão dos conselheiros federais Adauto Lúcio Cardoso e Dario de Almeida Magalhães, e de Virgílio de Melo

\footnotetext{
${ }^{118}$ CF-OAB, Ata de sessão do Conselho Federal, 6/6/1944.

${ }^{119}$ CF-OAB, Ata de sessão do Conselho Federal, 6/6/1944.

${ }^{120}$ GUIMARÃES, Lúcia Maria Paschoal; BESSONE, Tânia. História da Ordem dos Advogados do Brasil. Criação, primeiros percursos e desafios (1930-1945). op. cit., p. 117.
} 
Franco, Belarmino de Austregésilo de Ataíde e Rafael Correia de Oliveira, no final de 1944. ${ }^{121}$ Um pedido de habeas corpus foi impetrado junto ao Tribunal de Apelação do Distrito Federal em favor dos detidos. O documento foi assinado por 92 advogados, encabeçados pelo presidente da OAB, Raul Fernandes. ${ }^{122}$

Já no ano seguinte, um habeas corpus em favor de Armando Sales de Oliveira, Otávio Mangabeira e Paulo Nogueira Filho - todos notórios opositores do Estado Novo e fundadores da UDN - foi concedido pelo Supremo Tribunal Federal (STF). Mais uma vez, tratou-se de uma ação coordenada do grupo de bacharéis liberais visando alcançar repercussão pública. À frente dela, estiveram o ilustre professor paulista (e que se tornaria presidente da UDN de São Paulo) Valdemar Ferreira e o conselheiro federal da OAB Targino Ribeiro. O documento foi subscrito por mais de 500 advogados, dentre os quais, Raul Fernandes. ${ }^{123}$ O grande número de signatários dos dois pedidos de habeas corpus sugere tanto capacidade organizativa por parte dos bacharéis liberais quanto um bom nível de adesão à sua causa no meio dos advogados

Ainda no final de 1944, integrantes do grupo de bacharéis liberais denunciaram a interferência do interventor federal Benedito Valadares nas eleições para a seção estadual da $\mathrm{OAB}$ de Minas Gerais, que ocorreram em $1^{\circ}$ de dezembro. Em carta dirigida ao presidente da OAB, Raul Fernandes, e datada do dia 30 de novembro, o conselheiro federal da Ordem Sobral Pinto acusou Valadares de intimidar advogados e usar a máquina estatal para influenciar no resultado do pleito. Quando a denúncia de Sobral Pinto foi lida na sessão de 5 de dezembro do Conselho Federal, o bacharel liberal Pedro Aleixo já acusara o interventor mineiro de ingerência nas eleições da OAB mineira. Dias depois, em 9 de dezembro, o presidente substituto da seção de Minas Gerais da

121 "Na sessão seguinte [do Conselho Federal da OAB], Augusto Pinto Lima comunicou aos presentes a prisão dos conselheiros Adauto Lúcio Cardoso e Dario de Almeida Magalhães, bem como os doutores Virgílio de Melo Franco, Belarmino de Austregésilo de Ataíde e Rafael Correia de Oliveira, não constando a existência de causa justificada dessas prisões, o que levou à convocação de sessão extraordinária para que se tomassem providências cabíveis e possíveis para a defesa dos presos. Informou ainda que, tendo se comunicado com o presidente do Conselho Federal, Raul Fernandes, este havia lhe delegado plenos poderes para a solução do caso." GUIMARÃES, Lúcia Maria Paschoal; BESSONE, Tânia. História da Ordem dos Advogados do Brasil. Criação, primeiros percursos e desafios (1930-1945), op. cit., p. 117.

${ }^{122}$ CARVALHO, Antônio Gontijo de, op. cit., p. 307.

${ }^{123}$ CARVALHO, Antônio Gontijo de, op. cit., p. 307. 
Ordem, Milton Campos, dirigiu-se aos representantes do estado no Conselho Federal (Dario de Almeida Magalhães, Odilon de Andrade e Alcino de Paula Salazar) para corroborar as denúncias de Sobral Pinto e Aleixo. ${ }^{124}$ Na carta, Milton Campos indicava explicitamente a responsabilidade de Valadares:

"O Governador do Estado planejou e realizou a mais franca e rude intervenção nesse pleito. Pessoalmente, organizou a lista de seus candidatos e por eles cabalou, dirigindo-se aos advogados eleitores, a muitos dos quais chamou ao Palácio para lhes pedir o voto. Pôs em campo os auxiliares da administração. Mobilizou banqueiros ligados ao Governo. ",125

Ademais, o presidente da $\mathrm{OAB}$ mineira procurou demonstrar que o ocorrido extrapolava o âmbito regional, na medida em que a interferência de Valadares representava um ataque tanto à autonomia da Ordem em relação ao governo quanto à liberdade profissional do advogado. ${ }^{126}$ Ao apreciar o caso, o Conselho Federal anulou as eleições de $1^{\circ}$ de dezembro, nomeou uma diretoria provisória para a seção mineira e convocou um novo pleito. ${ }^{127}$ Sem dúvida, a decisão representou uma vitória dos bacharéis liberais, reafirmando sua hegemonia no Conselho Federal e garantindo a sua permanência na seção de Minas Gerais, estado no qual o grupo tinha uma de suas principais bases.

\section{3.) A ação oposicionista do Conselho Federal em 1945}

No ano de 1945, aproveitando-se da liberalização política, o Conselho Federal da $\mathrm{OAB}$ dirigiu ataques crescentemente contundentes ao regime vigente. A entidade não mais se restringiu a atacá-lo pelo desrespeito às prerrogativas dos advogados. Alçou a sua oposição ao governo a um outro patamar, apresentando-a como realizada em nome

\footnotetext{
${ }^{124}$ VENÂNCIO FILHO, Alberto. Notícia histórica da OAB, op. cit., p. 67. DULLES. John W. F., op. cit., p. 297.

${ }_{125}$ VENÂNCIO FILHO, Alberto. Notícia histórica da $O A B$, op. cit., p. 68.

${ }^{126}$ Ibidem, p. 68-69.

${ }^{127}$ CF-OAB, Atas de sessões do Conselho Federal, 26/3/1945, 24/4/1945 e 11/5/1945.
} 
da democracia e da tradição jurídica liberal. No último ano do Estado Novo, o Conselho Federal manifestou-se sobre os principais acontecimentos políticos do país, em especial em relação às iniciativas governamentais interpretadas como protelatórias do retorno à democracia. As posições do órgão nestas ocasiões estiveram plenamente afinadas com as assumidas pela UDN, formalmente organizada em abril de 1945.

O conselheiro Pinto Lima liderou a cruzada final da OAB contra Vargas, na qual o Conselho Federal manteve-se unido, aprovando unanimemente as moções oposicionistas propostas pelo seu presidente substituto. Assim, na primeira sessão do Conselho Federal de 1945, ocorrida no dia 26 de março, Pinto Lima fez aprovar uma moção em comemoração à "libertação política do país, que se verificou no glorioso dia 22 de fevereiro último" ${ }^{\text {"128 }}$. Embora não explicitasse, é praticamente certo que se referisse à entrevista de José Américo de Almeida ao Correio da Manhã, que representou tanto uma vitória oposicionista contra a censura estadonovista à imprensa quanto um marco decisivo na organização udenista.

Pinto Lima voltou a carga no mês seguinte. Em sessão de 17 de abril, pediu ao Conselho um voto de profundo pesar pela morte de Franklin Roosevelt. Os conselheiros então se colocaram em pé para a homenagem ao presidente norte-americano. Na moção apresentada ao Conselho, Pinto Lima destacou o papel de Roosevelt (chamado de "paladino da liberdade" e "dínamo da democracia") na vitória dos Aliados contra o Eixo. E, implicitamente, associou o combate ao nazifascismo à luta contra o Estado Novo:

"O Conselho Federal da Ordem dos Advogados do Brasil, nesta campanha do bem contra o mal, tem se mantido, na primeira linha, empunhando as armas da palavra, a fim de convencer a alma democrática nacional da necessidade da vitória contra as forças organizadas da prepotência, encarnadas nos governos totalitários, dominantes, mesmo em terras americanas.(...) Não medrará nas terras de Santa Cruz a erva daninha arrancada a tiros de canhão

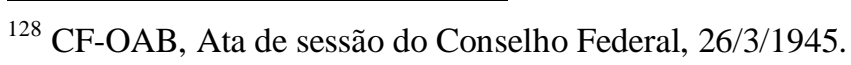


pelos homens, que juraram a paz, como sendo o resultado do sangue dos heróis derramado nos campos de batalha, verdadeira semente da democracia, pondo fim à tragédia da guerra. "129

Se o decreto antitruste baixado por Vargas em meados de 1945 (batizado de Lei Malaia) consolidou a aproximação do presidente com os comunistas, ele também despertou forte reação da oposição liberal. Raul Fernandes e Sobral Pinto, pelos jornais, destacaram-se como críticos do decreto. Poucos dias depois de expedido o decreto, Pinto Lima e Sobral Pinto propuseram que o Conselho Federal consignasse em ata um veemente protesto contra o mesmo, aprovado por unanimidade. É verdade que os conselheiros autores da proposta a justificaram em nome da defesa da "ordem jurídica da Nação", supostamente contrariada pelo decreto, mas o posicionamento do Conselho Federal contra a medida desvelava convicções liberais (que repudiavam, portanto, a intervenção estatal na economia), compromissos com interesses do setor privado (incluindo os ligados ao capital estrangeiro) e receio de que se tratasse do primeiro passo para a socialização dos meios de produção. ${ }^{130}$ Também o Conselho do Distrito Federal da $\mathrm{OAB}$, por iniciativa de Pinto Lima, registrou em ata um protesto, aprovado por unanimidade, contra a Lei Malaia, sob o argumento de que o "decreto faz a ordem jurídica no Brasil regredir, constituindo um atentado contra a consciência do povo brasileiro". Engrossando o coro dos bacharéis contra o decreto, a Associação dos Advogados de São Paulo (AASP) também o condenou. ${ }^{131}$

Como a UDN, o Conselho Federal da Ordem sobressaltou-se com o queremismo. Pouco depois do lançamento do movimento, Pinto Lima “comunicou ao Conselho as cenas deprimentes que se passaram quando um bando político aos gritos de queremos Getúlio, apedrejou uma Faculdade de Direito, situada à rua do Catete. "132 Provavelmente, o fato a que se refere Pinto Lima ocorreu depois do comício

\footnotetext{
${ }^{129}$ CF-OAB, Ata de sessão do Conselho Federal, 17/4/1945.

${ }^{130}$ CF-OAB, Ata de sessão do Conselho Federal, 26/6/1945. DULLES, John W. F., op. cit., p. 344-345. VENÂNCIO FILHO, Alberto. Lei Malaia. In: ABREU, Alzira Alves de et alli. (coord.), op. cit.

${ }^{131}$ O Jornal, 28/6/1945, p. 1, $2^{\text {a }}$ seção.

${ }^{132}$ CF-OAB, Ata de sessão do Conselho Federal, 28/8/1945.
} 
queremista realizado no Largo da Carioca, no Rio de Janeiro, em 20 de agosto de 1945. Ao final do evento, os participantes, em passeata, dirigiram-se ao Palácio Guanabara. No caminho, apedrejaram estudantes da Faculdade Nacional de Direito que ostentavam propaganda do candidato Eduardo Gomes. ${ }^{133}$

Na sessão realizada em 18 de setembro, o Conselho Federal aprovou uma moção antiqueremista apresentada por Pinto Lima. O organismo justificava sua tomada de posição quanto ao queremismo em função de seu "dever constitucional" de "defender a ordem jurídica do país. ”. Fundamentalmente, a declaração defendia o cumprimento da legislação eleitoral decretada por Vargas no início do ano, recusando o adiamento das eleições presidenciais. Ao afirmar que o parlamento a ser eleito em 2 de dezembro poderia se reunir como Assembléia Constituinte, a moção visava o slogan queremista “Constituinte com Getúlio". O documento incluía uma defesa, de base liberal, da realização das eleições ${ }^{134}$, as quais, ao restabelecerem a soberania popular, afirmava a moção, restaurariam a legitimidade do poder político:

Manifesta, pois, o Conselho a sua segurança de que o processo de redemocratização do país não sofrerá interrupções nem delongas e que, na data marcada, serão realizadas, sem coações nem temores, as eleições que assegurem ao Brasil o restabelecimento do poder público em bases legítimas, a restauração da confiança e a fundação de um regime político de justiça social em que se harmonizem a autoridade e a liberdade. ${ }^{135}$

Finalmente, a moção apelava aos "órgãos representativos de todas as classes sociais" e, sobretudo, às Forças Armadas, para que atuassem em favor da realização das eleições. ${ }^{136}$ Em seguida à aprovação do documento, Sobral Pinto sugeriu que fosse dado conhecimento de seu conteúdo aos chefes militares, ao clero e às congregações

\footnotetext{
133 VALE, Osvaldo Trigueiro do. O general Dutra e a redemocratização de 45. Rio de Janeiro: Civilização Brasileira, 1978, p. 119-122. CARONE, Edgard, op. cit., p. 333.

${ }^{134}$ CF-OAB, Ata de sessão do Conselho Federal, 18/9/1945.

${ }^{135}$ CF-OAB, Ata de sessão do Conselho Federal, 18/9/1945.

${ }^{136}$ CF-OAB, Ata de sessão do Conselho Federal, 18/9/1945.
} 
operárias. Porém, acabou por prevalecer a proposta do conselheiro udenista Nelson Carneiro de que o manifesto fosse publicado pela imprensa, endereçado " $a$ todas as classes sociais e, especialmente, às Forças Armadas." 137 De fato, vários jornais cariocas noticiaram a sessão do Conselho Federal e reproduziram, parcial ou integralmente, o documento aprovado pelo organismo. ${ }^{138}$

A moção Pinto Lima angariou manifestações de apoio, especialmente entre os bacharéis. O Conselho Federal recebeu correspondências com este teor da Associação Brasileira de Educação, entidade que também se encontrava engajada na luta contra o Estado Novo, ${ }^{139}$ do Conselho Seccional da OAB do Estado do Rio de Janeiro e do Instituto dos Advogados de Minas Gerais. ${ }^{140}$

No entanto, a moção do Conselho Federal da OAB foi contestada pelos queremistas. No dia 21 de setembro, o jornal $O$ Globo publicou uma matéria assinada pelo Comitê Pró-Candidatura Getúlio Vargas, com sede na capital federal, com o título, impresso em letras garrafais "RESPOSTA À ORDEM dos ADVOGADOS do BRASIL". O anúncio trazia duas listas contrapostas. A da esquerda trazia o nome dos 21 conselheiros federais que tinham aprovado a moção de 18 de setembro. Embaixo da lista, havia um texto que pretendia resumir a moção do Conselho Federal: "Apelamos para o exército afim de que tome conhecimento desta nossa reunião de 21 advogados ilustres, ou seja, 21 cidadãos, para que, pela força, seja feita a nossa vontade." A lista da direita trazia o nome de 30 operários presentes a uma reunião convocada pelo Comitê Pró-Candidatura Getúlio Vargas, cuja deliberação era assim resumida: “Apelamos para a nação a fim de que, tomando conhecimento da nossa reunião de 30 cidadãos, sejam realizadas eleições, livres e honestas, para a Assembléia Constituinte." O anúncio terminava com o seguinte texto:

${ }^{137}$ CF-OAB, Ata de sessão do Conselho Federal, 18/9/1945.

138 Diário de Notícias, 19/9/1945, $1^{\text {a }}$ seção, p. 3; Jornal do Comércio, 19/9/1945, p. 3; O Jornal, 19/9/1945, 1 a seção, p. 3.

${ }^{139}$ XAVIER, Libânia; CUNHA, Luís Antônio. Associação Brasileira de Educação (ABE). In: ABREU, Alzira Alves de et alli (coord.), op. cit.

140 CF-OAB, Atas de sessões do Conselho Federal, 2/10/1945 e 9/10/1945; Jornal do Comércio, 26/9/1945, p. 4. 
"Houve uma reunião na Ordem dos Advogados do Brasil, no Rio, na qual tomaram parte 21 advogados, ou seja, perante a nação, 21 cidadãos portadores de 21 votos. Houve também, no Rio, noutro local, uma reunião na qual tomaram parte 30 operários, ou seja, perante a nação, 30 cidadãos e, portanto, 30 votos. A nação, pelas urnas, não se fará representar nunca pela qualidade dos seus votos, porém, sempre, pela quantidade. Acreditamos que a moção lançada pela Ordem dos Advogados foi sobrepujada pela moção feita pelos 30 operários, portanto 30 votos são mais do que 21 votos. Já que o que se quer é Democracia, que se faça no Brasil, a verdadeira Democracia." (grifos originais) ${ }^{141}$

Assim, de maneira provocativa, os queremistas atacavam a pretensão dos conselheiros federais - explícita no manifesto de apoio dos bacharéis a Eduardo Gomes - de serem os intérpretes do interesse nacional e os defensores por excelência do bem comum. E, no fundo, a matéria questionava o caráter da democracia propugnada pelo Conselho Federal, sugerindo o seu viés oligárquico.

A publicação de $O$ Globo motivou Sobral Pinto a escrever a Roberto Marinho, proprietário do periódico, lamentando que tivesse aceitado publicar a matéria paga pelos queremistas. O advogado militante da oposição liberal, na carta, enaltecia Orlando Ribeiro Dantas, dono do Diário de Notícias, que se recusara a publicar a mesma matéria. Sobral Pinto dizia que esta continha “desrespeito, rasteiro e vulgar” à OAB. E qualificava de "interesses subalternos de uma facção revolucionária” os interesses por detrás do manifesto. ${ }^{142} \mathrm{Na}$ sessão do Conselho Federal de 25 de setembro, Sobral Pinto solicitou - e os conselheiros anuíram - que sua carta a Marinho fosse transcrita em ata. $^{143} \mathrm{Na}$ mesma sessão, anunciou-se o recebimento de telegrama enviado pelo advogado Benigno Rodrigues Fernandes, de Nova Friburgo (Rio de Janeiro), protestando contra a aprovação, pelo organismo, da moção de 18 de setembro. Benigno Fernandes seria um dos signatários do protesto contra a atuação partidarizada do

${ }^{141}$ O Globo, 21/9/1945, p. 5.

142 DULLES. John W. F., op. cit, p. 363. Jornal do Comércio, 27/9/1945, p. 3.

${ }^{143}$ No entanto, não encontrei, na ata desta sessão, a transcrição da referida carta de Sobral Pinto. 
Conselho Federal publicado no diário Tribuna Popular, em 3 de outubro de 1945. ${ }^{144}$ Numa tentativa de intimidação, Sobral Pinto solicitou que se oficiasse ao advogado fluminense, "interpelando-se sobre a espécie de autoridade que pretende recusar à Ordem." 145

Na mesma sessão de 25 de setembro, Pinto Lima pronunciou-se, mais uma vez, sobre a situação política nacional, negando que a $\mathrm{OAB}$ atuasse partidariamente. Segundo o presidente da seção do Distrito Federal, a ação da Ordem visava tão somente o retorno do país à ordem constitucional. No seu discurso, Pinto Lima defendeu a repressão à campanha queremista, mostrando que a defesa que fazia das liberdades civis conhecia limites:

"Não se compreende que uma autoridade pública, de boa fé, permita o triste espetáculo de uma propaganda deletéria, pelo rádio, pela imprensa, pelas faixas e pelos comícios, com o fim criminoso de burlar o texto claro, insofismável da lei eleitoral, cânone jurídico, para nortear a futura ordem constitucional do Brasil livre." 146

Finalmente, respaldando-se em pronunciamento do ministro da Guerra, Góes Monteiro, ele apelava para que as Forças Armadas garantissem o cumprimento da legislação eleitoral, com a realização das eleições parlamentares e para presidente da República. $^{147}$

Num novo lance contra o queremismo, os bacharéis liberais, por meio do Conselho Seccional do Distrito Federal da OAB, encaminharam uma consulta ao Tribunal Superior Eleitoral (TSE) sobre o caráter do parlamento a ser eleito em dezembro - se ordinário ou constituinte. A decisão do tribunal - de que o parlamento, se assim deliberasse, poderia se reunir em Assembléia Constituinte - foi comemorada pelos bacharéis liberais, convencidos de que ganharam um importante argumento contra

\footnotetext{
${ }^{144}$ Tribuna Popular, 3/10/1945, p. 1-2.

145 CF-OAB, Ata de sessão do Conselho Federal, 25/9/1945.

${ }^{146}$ CF-OAB, Ata de sessão do Conselho Federal, 25/9/1945.

${ }^{147}$ CF-OAB, Ata de sessão do Conselho Federal, 25/9/1945.
} 
o queremismo. ${ }^{148} \mathrm{Na}$ sessão do Conselho Federal da OAB de 2 de outubro, o conselheiro Hariberto de Miranda Jordão comunicou que o TSE havia "aceito a tese defendida pelo Conselho acerca da competência constituinte do parlamento convocado, independentemente da necessidade de modificação da legislação vigente. " de outubro, o Diário de Notícias publicou uma entrevista com Sobral Pinto a respeito do tema, na qual afirmava:

"Nela [na decisão do tribunal] diviso a liquidação definitiva desta atoarda agitadora que se vem fazendo, com puros objetivos revolucionários, em torno da convocação da 'Constituinte'. Com a sua decisão, o Tribunal tirou à campanha em prol dessa Constituinte toda e qualquer justificação."

Assim, Sobral Pinto acreditava que - ao demonstrar que a Constituinte já estava garantida pela legislação eleitoral vigente - os liberais desarticulavam uma das bandeiras do queremismo. Ainda no final de setembro, e antes da decisão do tribunal, a Tribuna Popular havia atacado a consulta encaminhada pela OAB do Distrito Federal ao TSE. O periódico comunista, ainda que propugnasse a convocação da constituinte, alegava que a legislação eleitoral em vigor previa apenas a formação de um parlamento ordinário a partir das eleições de dezembro. ${ }^{151}$

Um pouco mais tarde, os jornais Tribuna Popular, Folha Carioca e $O$ Radical (estes dois últimos comprometidos com o queremismo) divulgaram um novo protesto de advogados contra a moção de 18 de setembro do Conselho Federal da OAB. ${ }^{152}$ A Tribuna Popular consagrou sua principal manchete de capa ao assunto: "Protestam advogados desta capital contra a intromissão do Conselho da Ordem em assuntos políticos". ${ }^{153}$ Os signatários - pouco menos de cinquenta advogados, sendo a maioria militantes do foro carioca - acusavam a entidade de atuar partidariamente, e embora não

\footnotetext{
${ }^{148}$ DULLES. John W. F., op. cit, p. 363-364.

${ }^{149}$ CF-OAB, Ata de sessão do Conselho Federal, 2/10/1945.

${ }^{150}$ Diário de Notícias, 3/10/1945, $1{ }^{\text {a }}$ seção, p. 4.

${ }^{151}$ Tribuna Popular, 28/9/1945, p. 3.

152 DULLES. John W. F., op. cit, p. 364-365.

${ }^{153}$ Tribuna Popular, 3/10/1945, p. 1-2.
} 
nomeassem o partido favorecido pelo Conselho Federal, era claro que se referiam à UDN. $^{154}$

Mais uma vez, Sobral Pinto levantou-se em defesa da moção. Numa afirmação duvidosa, asseverou que, assim como ele, a grande maioria dos conselheiros federais nunca tinha sido "político de partido" ou "estado a serviço de qualquer facção política”. ${ }^{155}$ E defendeu a moção do Conselho Federal com o seguinte argumento: uma das obrigações regulamentares da Ordem era defender a ordem constitucional; ora, o cumprimento da legislação eleitoral contribuía para se fazer com que o país entrasse na ordem constitucional. ${ }^{156}$

Apesar do sólido apoio de que gozavam no interior da categoria profissional, o grupo liberal, nos últimos meses do Estado Novo, teve de enfrentar questionamentos sobre a sua condução no Conselho Federal da Ordem. A resistência ao engajamento oposicionista do organismo originava-se de advogados esquerdistas (a matéria do Diário de Notícias que divulga a defesa de Sobral Pinto da moção do Conselho Federal de 18 de setembro diz que os signatários do manifesto divulgado pela Tribuna Popular eram membros do $\mathrm{PCB}^{157}$ - o que é bastante factível) e que não pertenciam à elite da profissão. De todo modo, os questionamentos alcançavam repercussão pública e força suficiente para obrigar o Conselho Federal a defender a sua ação.

Em 10 de outubro, Vargas, por meio do Decreto-Lei $n^{\circ}$ 8.063, alterou a legislação eleitoral, antecipando as eleições estaduais para o dia 2 de dezembro de 1945 , mesma data em que seriam eleitos o novo presidente da República e os membros do Congresso Nacional. O efeito previsível da antecipação era o favorecimento dos candidatos oficiais, beneficiários das máquinas das interventorias federais nos estados. Os partidos de oposição (UDN, Partido Republicano e Partido Libertador) condenaram veementemente a medida. ${ }^{158}$

\footnotetext{
${ }^{154}$ Tribuna Popular, 3/10/1945, p. 1-2.

${ }^{155}$ Diário de Notícias, 4/10/1945, $1{ }^{\text {a }}$ seção, p. 3; DULLES. John W. F., op. cit, p. 363-365.

${ }^{156}$ Diário de Notícias, $4 / 10 / 1945,1^{\text {a }}$ seção, p. 3.

${ }^{157}$ Diário de Notícias, 4/10/1945, $1^{\text {a }}$ seção, p. 3.

${ }^{158}$ VALE, Osvaldo Trigueiro do, op. cit., p. 151-154. ALMEIDA JÚNIOR, Antonio Mendes. Do declínio do Estado Novo ao suicídio de Getúlio Vargas. In: FAUSTO, Boris (direção). História Geral da
} 
A manobra de Vargas radicalizou a posição do Conselho Federal da OAB, convencido de que a redemocratização do país passava pela deposição do presidente. $\mathrm{O}$ Diário de Notícias, ao descrever a reunião do Conselho Federal de 16 de outubro, revelava a exaltação dos ânimos entre os conselheiros federais. Nesta reunião, Pinto Lima apresentou uma moção que considerava o Decreto-Lei n 8.063 "gerador da anarquia e do tumulto sobre a obra de restauração das instituições democráticas do Brasil." "159 No entanto, Artur Costa, representante de Santa Catarina no Conselho Federal, apoiado por José Marcelo Moreira, representante do Mato Grosso, alegou a incompetência do organismo para se pronunciar sobre o assunto. Astutamente, Sobral Pinto, que sustentava a moção Pinto Lima, propôs que o Conselho votasse a preliminar de incompetência levantada por Artur Costa e que, caso esta fosse rejeitada, o conjunto dos conselheiros aprovaria o documento. Provavelmente prevendo a sua derrota, Costa e Marcelo Moreira retiraram sua proposta. Assim, o Conselho Federal aprovou, por unanimidade, o texto apresentado por Pinto Lima. ${ }^{160}$

Logo no seu início, a moção se justificava em nome da "restauração da ordem jurídica democrática" e apresentava as fontes de legitimidade da atuação política da OAB: os mandamentos do Código de Ética Profissional e a "missão histórica" do órgão (nos termos do documento, “a própria origem da instituição”). ${ }^{161}$

O argumento que fundamenta a moção é que, ao contrário da legislação eleitoral vigente desde o início de 1945, o Decreto-Lei no 8.063 não fora elaborado pelo TSE, nem se baseara na opinião pública, "pelos seus órgãos responsáveis e qualificados”. A temática da opinião pública surge em outro trecho no qual se afirma que o decreto em questão afrontava "os pronunciamentos de órgãos que exprimem, com autenticidade e insuspeição, a opinião pública do país. " ${ }^{162}$ Considerando-se clarividente em relação aos

Civilização Brasileira. São Paulo: Difel, 1981, tomo III, volume 3, p. 238. SKIDMORE, Thomas E. Brasil: de Getúlio a Castelo Branco (1930-1964). Rio de Janeiro: Paz e Terra, 1976, p. 76-77.

${ }^{159}$ CF-OAB, Ata de sessão do Conselho Federal, 16/10/1945.

${ }^{160}$ Diário de Notícias, 17/10/1945, $1^{\text {a }}$ seção, p. 3.

${ }^{161}$ CF-OAB, Ata de sessão do Conselho Federal, 16/10/1945. A íntegra da moção de 16 de outubro do Conselho Federal encontra-se reproduzida em: Diário de Notícias, 17/10/1945, $1^{a}$ seção, p. 3.

162 CF-OAB, Ata de sessão do Conselho Federal, 16/10/1945. Diário de Notícias, 17/10/1945, $1^{\text {a }}$ seção, p. 3. 
interesses da nação e "qualificada" pelos ilustres bacharéis que o compunham, o Conselho Federal da $\mathrm{OAB}$ se via como parte da opinião pública.

A moção de 16 de outubro não clamava explicitamente o afastamento de Vargas da presidência, mas denunciava a "transgressão dos compromissos assumidos pelo Governo, esperando que, hoje como ontem, o patriotismo, a decisão, a serenidade daqueles que custodiam os destinos da Nação, intervenham para restabelecer a ordem jurídica violada. "163 No entanto, a esta altura dos acontecimentos, os bacharéis liberais já conspiravam, com os chefes militares, pela deposição de Vargas. ${ }^{164}$ A declaração de voto apresentada por Sobral Pinto na reunião de 16 de outubro e incorporada como parte da moção aprovada pelo Conselho Federal era uma clara pregação golpista, ao afirmar que o Decreto-Lei no 8.063 "não pode ser encarado como problema de Direito, devendo, pelo contrário, ser tido como problema de pura força militar, da alçada exclusiva das Classes Armadas. " 165 Ainda mais claro foi Pinto Lima, numa altercação com o conselheiro federal Nelson Carneiro descrita pelo Diário de Notícias, mas omitida pela ata da reunião daquele dia:

“Propôs (...) o sr. Nelson Carneiro (...) que os juristas saíssem à rua, em comício público, a fim de esclarecer o povo sobre a situação de humilhação e de desamparo legal a que foi reduzida a nação. $O$ assunto foi debatido, havendo o sr. Pinto Lima lembrado que, na próxima sexta-feira, mais de mil advogados se reunirão no Teatro Municipal, numa demonstração de unanimidade em torno da causa da redenção democrática. Isso valeria por um comício público. Insistiu, entretanto, o sr. Nelson Carneiro na sua proposta, afirmando que a próxima reunião do Teatro Municipal consistiria de uma homenagem ao brigadeiro Eduardo Gomes e o que sugeria era que os advogados esclarecessem o povo sobre a gravidade da situação à margem de qualquer partidarismo. Interveio,

\footnotetext{
${ }^{163}$ CF-OAB, Ata de sessão do Conselho Federal, 16/10/1945.

${ }^{164}$ BENEVIDES, Maria Victoria de Mesquita, op. cit., p. 57.

${ }^{165}$ Diário de Notícias, 17/10/1945, $1^{\text {a }}$ seção, p. 4.
} 
novamente, o sr. Pinto Lima, para afirmar: ' - O que é preciso é afastar o ditador do poder'. ,"166

O trecho, igualmente, põe a nu a opinião de conselheiros federais de que a restauração da ordem jurídica e a candidatura de Eduardo Gomes eram indissociáveis, malgrado a cautela de Nelson Carneiro - ele próprio um udenista -, preocupado em marcar a diferença entre a atuação partidária e a da OAB. Com o objetivo de ampliar a base social de suas posições, num momento decisivo de sua luta contra Vargas, o Conselho Federal decidiu dirigir-se às suas seções estaduais para que colocassem em marcha "uma grande campanha de esclarecimento do povo" sobre a necessidade de se restabelecer a ordem jurídica. ${ }^{167}$

A seção mineira da $\mathrm{OAB}$ e o Instituto dos Advogados de Minas Gerais solidarizaram-se com o Conselho Federal pela aprovação do documento. ${ }^{168}$ Além disto, ele foi noticiado e reproduzido pelos jornais oposicionistas do Rio de Janeiro. ${ }^{169}$ Porém, do outro lado da trincheira, a moção de 16 de outubro foi atacada. A Gazeta de Notícias, alinhada à candidatura de Dutra, acusou o Conselho Federal de fugir às atribuições estabelecidas pelo Estatuto da OAB e de se tornar uma sucursal da UDN. O jornal ainda afirmou que os conselheiros federais se moviam por "apetites políticos": 170

"O povo, que já sofreu sob as garras dessa aristocracia de traidores [os partidários de Eduardo Gomes] bem os conhece e não se deixa embair pelos cartazes de propaganda que lhe exibem, ainda quando enfeitados com o verniz da cultura jurídica ou quando expostos na vitrina de instituições que tinham o dever

\footnotetext{
166 Diário de Notícias, 17/10/1945, $1^{\text {a }}$ seção, p. 3.

${ }^{167}$ Diário de Notícias, 17/10/1945, $1^{\text {a }}$ seção, p. 3.

${ }^{168}$ CF-OAB, Atas de sessões do Conselho Federal, 23/10/1945 e 30/10/1945.

${ }^{169}$ Correio da Manhã, 17/10/1945, p. 12; O Jornal, 17/10/1945, 2 a seção, p. 1-2. O Jornal do Comércio também reproduziu a moção: O Jornal do Comércio, 17/10/1945, p. 4.

${ }^{170}$ DULLES. John W. F., op. cit., p. 372. LEAL, Carlos Eduardo. Gazeta de Notícias. In: ABREU, Alzira Alves de et alli (coord.), op. cit. Gazeta de Notícias, 19/10/1945, p. 3.
} 
de se manter imparciais e justas - como a Ordem dos Advogados - agora transformada em bazar de escândalos. "171

Em artigo publicado em A Noite - jornal encampado pelo governo federal em 1940 -, José Soares Maciel Filho, autor de discursos de Vargas, acusou Raul Fernandes de ser "o leader dos grandes negócios estrangeiros no Brasil" e de um grupo de “advogados políticos” favoráveis a um golpe militar contra o chefe do Estado Novo. ${ }^{172}$

\section{4.) O manifesto de apoio dos advogados cariocas a Eduardo Gomes}

Desde, ao menos, meados de 1945, o grupo de bacharéis liberais preparava um manifesto de apoio do meio jurídico à candidatura de Eduardo Gomes. ${ }^{173}$ À comissão organizadora do mesmo, liderada por Adauto Lúcio Cardoso, pertenciam os também conselheiros federais da OAB Targino Ribeiro e Dario de Almeida Magalhães. A lista de signatários do documento contava, segundo a fonte, entre mil e dois mil nomes, sendo a maioria advogados do Distrito Federal. ${ }^{174}$

Ao menos 23 dentre os 58 membros do Conselho Federal da OAB assinaram o documento: Antônio Carvalho Guimarães, Adauto Lúcio Cardoso, Alcino Salazar, Arnoldo Medeiros da Fonseca, Augusto Pinto Lima, Daniel de Carvalho, Dario de Almeida Magalhães, Décio Bastos Coimbra, Francisco Martins de Almeida, Hariberto de Miranda Jordão, Heráclito Sobral Pinto, Joaquim Murilo Silveira, José Augusto Bezerra de Medeiros, José Ferreira de Souza, José Telles da Cruz, Justo Rangel Mendes de Moraes, Luiz Lopes de Souza, Mário Carvalho de Vasconcelos, Nelson de Souza Carneiro, Oscar Stevenson, Osvaldo Trigueiro, Targino Ribeiro e Ubaldo Ramalhete. ${ }^{175}$

\footnotetext{
${ }^{171}$ Gazeta de Notícias, 19/10/1945, p. 3.

${ }^{172}$ DULLES. John W. F., op. cit., p. 375.

173 Adauto Lúcio Cardoso, numa sessão do Conselho Seccional da OAB do Distrito Federal dirá que o manifesto começou a correr em março de 1945. GUIMARÃES, Lúcia Maria Paschoal; BESSONE, Tânia. História da Ordem dos Advogados do Brasil. Criação, primeiros percursos e desafios (1930-1945), op. cit., p. 121.

${ }^{174}$ Diário Carioca, 28/6/1945, p. 1 e 11; Correio da Manhã, 19/10/1945, p. 12; Diário de Notícias, 20/10/1945, $1^{\text {a }}$ seção, p. 1 e 3; CF-OAB, Ata de sessão do Conselho Federal, 23/10/1945; Jornal do Comércio, 20/10/1945, p. 4.

${ }^{175}$ Diário Carioca, 28/6/1945, p. 1 e 11. Correio da Manhã, 19/10/1945, p. 3.
} 
O manifesto evidenciava a visão que os bacharéis liberais tinham de seu papel político naquela conjuntura. Antes de tudo, eles se consideravam uma elite esclarecida que tinha a incumbência de conduzir o país rumo à reconquista da democracia. Esta preeminência devia-se à tradição liberal de que eram portadores, mas também às peculiaridades do métier que exerciam. Ao contrário do "povo", que perdera sua “capacidade de julgamento" em função da censura à imprensa e da restrição ao debate público, os bacharéis haviam preservado a sua capacidade de discernimento:

“A demorada supressão dos órgãos e dos meios de normal desenvolvimento da vida pública, agravada pela atuação permanente dos aparelhos estatais de deformação, amplificação e eliminação da publicidade, ao influxo das conveniências do governo, desorganizou a opinião pública, nas fontes profundas de sua elaboração, privando as massas de quaisquer critérios para a aferição de valores sociais e politicos. (...) O fato de restarem, no Brasil, as elites intelectuais como únicos redutos imunes da opinião pública, lhes confere uma enorme soma de encargos ao processo da restauração democrática. E, dentre as categorias profissionais que integram essas elites, são os juristas e advogados a classe mais responsável, por ser também aquela em que, por causa do trato do Direito e das leis, é mais extenso o número de seus membros que adquirem exata noção dos problemas políticos fundamentais relacionados com o Direito público. „176

Os autores do manifesto destacaram a centralidade das eleições presidenciais no processo de retorno à ordem jurídica. Numa passagem bem ao gosto do bacharelismo, citaram, no original, um artigo da Constituição Francesa de 1795 - do moderado período do Diretório da Revolução Francesa, com o qual se identificavam - que sublinha a importância das boas escolhas nas eleições para o destino da República. ${ }^{177}$

\footnotetext{
${ }^{176}$ O manifesto foi publicado em: Diário Carioca, 28/6/1945, p. 1 e 11 e Correio da Manhã, 17/10/1945, p. 12.

177 Tratava-se do artigo 376 da Constituição Francesa de 1795: "Les citoyens se rappeleront sans cesse, que c'est de la sagesse des choix dans les assemblées électorales que dépendent principalement la durée, la conservation et la prosperité de la Republique." Em tradução literal: Os cidadãos lembrar-se-ão, sem
} 
Os bacharéis liberais justificam a "sabedoria da escolha" feita em relação a Eduardo Gomes pela trajetória deste, marcada pelo compromisso com a justiça e a liberdade. No entanto, herdeiros que eram da Campanha Civilista, veem-se obrigados a explicar o seu apoio a um candidato militar, salientando "na candidatura de Eduardo Gomes, sua origem e seu caráter eminentemente civis. ",178

Um dos derradeiros atos da mobilização dos bacharéis liberais contra o Estado Novo foi o evento realizado em 19 de outubro de 1945, no Teatro Municipal do Rio de Janeiro, para a entrega do seu manifesto de apoio à candidatura Eduardo Gomes. A comissão organizadora do evento era composta pelos então conselheiros federais Adauto Lúcio Cardoso, Augusto Pinto Lima, Dario Almeida Magalhães, Sobral Pinto, Justo Mendes de Morais e Targino Ribeiro e também por Bruno Almeida Magalhães, Francisco Serrano Neves, Jorge Dyott Fontenell e Odilon Braga.

A imprensa oposicionista mobilizou-se em favor do evento dos advogados. Desde as vésperas até o dia do ato, divulgou notícias sobre o evento, publicou o manifesto e informou que o documento encontrava-se disponível, na tesouraria da $\mathrm{OAB}$, para novas adesões. ${ }^{179} \mathrm{O}$ Diário de Notícias procurou convencer seus leitores sobre a legitimidade da atuação oposicionista do Conselho Federal da OAB, provada pelo comparecimento dos advogados ao evento:

"Mais de 1.000 advogados se solidarizam, hoje, com o brigadeiro Eduardo Gomes. Aqueles que viram, nas recentes atitudes do Conselho Federal da Ordem dos Advogados, a mera consequência de uma infiltração de elementos oposicionistas, em seu seio, serão desmentidos esta tarde, quando a grande massa de advogados e juristas consagrará e ratificará, de público, as posições que

cessar, que é da sabedoria das escolhas feitas nas assembléias eleitorais que dependem, principalmente, a duração, a conservação e a prosperidade da República.

${ }_{178}$ Diário Carioca, 28/6/1945, p. 1 e 11; Correio da Manhã, 17/10/1945, p. 12.

179 Correio da Manhã, 17/10/1945, p. 12 e 19/10/1945, p. 12; O Jornal, 17/10/1945, p. $2{ }^{\text {a }}$ seção, p. 1; Diário de Notícias, 19/10/1945, $1^{\text {a }}$ seção, p. 3. 
aquele importante órgão representativo de classe assumiu, ao enfrentar, reiteradamente, o poder ditatorial. "180

Note-se, de passagem, que, no trecho citado, o periódico admitia que o manifesto de apoio ao candidato udenista e a cerimônia no Teatro Municipal eram obra do Conselho Federal da OAB.

No mesmo dia 19 de outubro, Rafael Corrêa de Oliveira, membro da oposição liberal, publicou no Diário de Notícias o artigo "Advogados do Brasil”, no qual o jornalista e advogado afirmou que, durante o Estado Novo, "os nossos advogados não fugiram às contingências mais perigosas do dever profissional. Antes, cumpriram esse dever com altivez, energia e capacidade de sacrificio. "181 Pela pena de Rafael Corrêa de Oliveira, descobre-se que, então, já surgira o mito da resistência generalizada dos advogados à ditadura estadonovista, cultivada pela $\mathrm{OAB}$ nas décadas seguintes. $\mathrm{A}$ resistência, acrescentava o artigo, inspirava-se nos ideais liberais, simbolizados pela figura de Rui Barbosa: “A legenda de Rui Barbosa, o indefectível defensor de todas as legítimas liberdades humanas, foi mantida pelos legistas brasileiros (...)"182 Ocultavase, no entanto, a colaboração de vários advogados e juristas com o Estado Novo e calava-se sobre o engajamento tardio da $\mathrm{OAB}$ ao movimento de oposição ao regime.

No dia seguinte, o evento foi coberto com grande destaque pela imprensa oposicionista. O Diário de Notícias e $O$ Jornal deram-lhe manchetes de capa e transcreveram os discursos ali pronunciados. ${ }^{183}$ Segundo o Diário de Notícias, o evento estava "destinado a influir, poderosa e imediatamente, sobre toda a nossa evolução política. $" 184$

Tomando a cobertura da imprensa como referência, pode-se recuperar os principais fatos e aspectos da cerimônia. Marcada para ter início às quatro horas da tarde, foi encerrada pouco depois das oito horas da noite. Segundo os jornais, o Teatro

\footnotetext{
180 Diário de Notícias, 19/10/1945, 1 a seção, p. 3.

${ }^{181}$ Diário de Notícias, 19/10/1945, $1^{\text {a }}$ seção, p. 3.

182 Diário de Notícias, 19/10/1945, $1^{\text {a }}$ seção, p. 3.

${ }^{183}$ Diário de Notícias, 20/10/1945, $1^{\text {a }}$ seção, p. 1 e 3; O Jornal, 20/10/1945, p. 1,2 e 7.

${ }^{184}$ Diário de Notícias, 20/10/1945, $1^{\text {a }}$ seção, p. 1 e 3.
} 
Municipal estava repleto de bacharéis. Uma fotografia parcial do teatro, publicada na primeira página da edição de 20 de outubro do Diário de Notícias, mostra-o, de fato, tomado de assistentes. Estiveram presentes alguns dos principais líderes da oposição: Artur Bernardes, Otávio Mangabeira, Virgílio de Melo Franco e José Américo. O evento foi presidido pelo decano dos advogados cariocas, Antônio Moitinho Dória, presidente da seção do Distrito Federal da OAB em 1941. Além do candidato udenista à presidência da República, três bacharéis discursaram. Eduardo Gomes foi saudado pelo público com lenços brancos, gesto repetido ao longo de sua campanha, numa alusão ao movimento liberal de Teófilo Otoni, no Império. ${ }^{185}$ Solicitado pelo público, Otávio Mangabeira desceu do camarote em que se encontrava para falar de improviso. ${ }^{186}$

Presidente da comissão organizadora do evento, Adauto Lúcio Cardoso, no seu discurso, destacou a coesão - suposta e almejada, ao menos - dos advogados em torno da candidatura do Brigadeiro: "nem mesmo nos fastos do civilismo, que foi a mais bela coalizão de forças da opinião civil em nossa terra, nunca o Foro se moveu assim unânime para (...) pesar numa luta política. ${ }^{187}$ Ademais, voltando a um tema já presente no texto do manifesto, o orador insistiu sobre o "espírito civil" da candidatura de Eduardo Gomes, que encarnava “as nossas aspirações de supremacia da lei sobre a vontade dos homens, o nosso alto ideal de preponderância da norma sobre o arbitrio." 188 Ainda segundo o conselheiro federal da OAB, o corpo legislativo do Estado Novo carecia de legitimidade, pois emanava unicamente da "vontade desautorizada de um homem". ${ }^{189}$ Assim, para Adauto Lúcio Cardoso, a legislação estadonovista só deveria ser obedecida nos "limites das necessidades sociais", na "medida dos imperativos da ordem" e dentro do "território do interesse público". 190 Ao finalizar seu discurso, o orador revelou os valores mais altos da ordem liberal pela qual pugnava: "Lutamos pelo Direito, pela Justiça e pela Liberdade." 191

\footnotetext{
185 BENEVIDES, Maria Victoria de Mesquita, op. cit., p. 44.

${ }^{186}$ Diário de Notícias, 20/10/1945, $1^{\text {a }}$ seção, p. 1 e 3; Jornal do Comércio, 20/10/1945, p. 3-4.

${ }^{187}$ Diário de Notícias, 20/10/1945, $1^{\text {a }}$ seção, p. 3.

${ }^{188}$ Diário de Not.ícias, 20/10/1945, $1^{\text {a }}$ seção, p. 3.

${ }^{189}$ Diário de Notícias, 20/10/1945, $1{ }^{a}$ seção, p. 3.

${ }^{190}$ Diário de Notícias, 20/10/1945, $1^{\text {a }}$ seção, p. 3.

${ }^{191}$ Diário de Notícias, 20/10/1945, $1{ }^{a}$ seção, p. 3.
} 
Outro conselheiro federal da OAB Targino Ribeiro leu o discurso enviado por Plínio Barreto, convidado para a cerimônia, na condição de representante dos advogados paulistas. Advogado prestigiado, Plínio Barreto presidira o Instituto dos Advogados de São Paulo no início da década de 1930 e participara, no mesmo período, da organização da seção paulista da OAB. Além disto, ele fora redator-chefe de $O$ Estado de S. Paulo e elegeu-se deputado constituinte pela UDN no pleito de dezembro de $1945 .{ }^{192}$ No discurso lido no Teatro Municipal Plínio Barreto acusou o Estado Novo de romper a ordem jurídica do país, ao substituir a Constituição Federal de 1934, restringir a independência do Judiciário, golpear a propriedade privada e a estabilidade das relações jurídicas (por meio de leis de efeito retroativo) e legislar conforme conveniências particulares. ${ }^{193}$ Ainda no discurso que escreveu, o advogado paulista, dirigindo-se diretamente a Eduardo Gomes, afirmou:

“Os juristas de São Paulo (...) vêm dizer (...) que esperam, tranqüilamente, que $V$. Exa., um militar, seja o restaurador da ordem jurídica no Brasil, que um civil, e o que é mais triste, um civil bacharel em ciências jurídicas e sociais, temerariamente destruiu. ",194

Desta maneira, Plínio Barreto reconhecia a ironia que a história reservara aos bacharéis brasileiros. Recorriam a um ilustre representante de um movimento políticomilitar que, na década de 1920, fustigara impiedosamente o bacharelismo para restaurar a tradição jurídica liberal - tão cara aos bacharéis - ameaçada por um bacharel. ${ }^{195}$

Convidado para discursar em nome dos advogados mineiros, Milton Campos enviou um discurso lido por José Monteiro de Castro. Campos já presidira a seção mineira da $\mathrm{OAB}$, assim como o Instituto dos Advogados de Minas Gerais. Fundador da

\footnotetext{
${ }^{192}$ MAYER, Jorge Miguel. BARRETO, Plínio. In: ABREU, Alzira Alves de et alli. (coord.), op. cit.

193 Jornal do Comércio, 20/10/1945, p. 3.

194 Jornal do Comércio, 20/10/1945, p. 3.

${ }^{195}$ No seu discurso, Adauto Lúcio Cardoso lamentou o enfraquecimento da cultura jurídica liberal durante o Estado Novo: "feneceu também a tradição de uma cultura jurídica que frondejara com Teixeira de Freitas e Ruy (...)”. Diário de Notícias, 20/10/1945, 1ª seção, p. 3.
} 
UDN, elegeu-se deputado constituinte no final de $1945 .{ }^{196}$ Por sua vez, Monteiro de Castro fora secretário de Educação de Minas Gerais entre 1938 e 1942. Tomara parte da delegação mineira ao Congresso Jurídico Nacional, realizada em 1943, do qual se retirara em protesto contra a interferência do governo federal no encontro. Como Milton Campos, foi eleito deputado constituinte pela UDN nas eleições de $1945 .{ }^{197}$

No discurso enviado, Milton Campos sugeriu a precedência dos bacharéis no combate ao Estado Novo: "Em Minas, como em todo o Brasil, os homens da lei foram o mais constante elemento de resistência durante os longos anos de ditadura em nossa Pátria." ${ }^{198}$ E a explicou pelas “condições de sua formação intelectual e pela natureza de suas atividades normais". ${ }^{199}$ Com estas palavras, Milton Campos reforçava a nascente legenda de resistência dos advogados contra a opressão estadonovista. Mas, elas não eram desprovidas de razão. Educados no liberalismo e exercendo um ofício ancorado na tradição jurídica liberal, o conflito dos bacharéis com um regime que procurava em outras ideologias os seus paradigmas para a organização estatal não poderia surpreender ninguém. Porém, o que o ilustre advogado mineiro não reconhecia é que uma parcela considerável dos bacharéis compatibilizou-se com o Estado Novo e que alguns deles, como Francisco Campos, dedicaram-se mesmo a dar corpo a uma cultura jurídica alternativa à liberal.

Ao discursar para a platéia do Teatro Municipal do Rio de Janeiro, Eduardo Gomes também discorreu sobre o tema do apego do bacharel à ordem jurídica liberal, associando-o, como Milton Campos, à sua formação universitária e profissão:

"Desde a educação superior, adquirida nos bancos acadêmicos, o jurista afeiçoa o espírito no rigor da lógica, no hábito da tolerância e na devoção da

\footnotetext{
${ }^{196}$ MALIN, Mauro. CAMPOS, Milton. In: ABREU, Alzira Alves de et alli. (coord.), op. cit.

${ }^{197}$ CASTRO, Monteiro de. In: ABREU, Alzira Alves de et alli. (coord.), op. cit.

${ }^{198}$ No mesmo evento, Eduardo Gomes discursaria: Enquanto durou o silêncio imposto ao país, houve um lugar de onde não se desertaram as vozes da liberdade: o dos conselhos dos juristas, quer no Instituto, que os congrega, quer nas sedes da Ordem, onde exercem uma função pública." Jornal do Comércio, 20/10/1945, p. 3 .

${ }^{199}$ Jornal do Comércio, 20/10/1945, p. 3.
} 
ordem. A atmosfera em que vive é a da normalidade jurídica; mal pode respirar num ambiente saturado de filtros revolucionários ou anárquicos. "200

Apresentando o seu programa político, o candidato udenista tratou da revisão da legislação estadonovista e, especialmente, da reorganização do Judiciário. Ele procedeu a um longo exame de medidas tomadas pelo regime vigente que atingiram a independência deste poder, como a restrição do habeas corpus e da atuação do Supremo Tribunal Federal (STF) e a criação do Tribunal de Segurança Nacional (TSN). ${ }^{201}$ Igualmente, o Brigadeiro acenou para os juízes, prometendo-lhes aumento salarial. Num trecho do discurso em que os juízes eram incensados, o candidato lamentou-lhes a condição de vida:

"Malgrado essas diminuições [referindo-se aos baixos salários dos juízes], que afastam da carreira profissionais capazes de enaltecê-la, os magistrados honra lhe seja! - confirmam, na quase totalidade, as esperanças que nele depositam as partes, sedentas de justiça. A probidade é a regra, na laboriosa corporação, que parece ter feito como os religiosos de S. Francisco, voto de pobreza. (...) É o milagre do idealismo profissional, o influxo do sentimento jurídico, premiando a desinteressada vocação de homens de integridade e de fé. ${ }^{, 202}$

A oposição liberal procurava apoio na magistratura para pôr termo ao Estado Novo. Apesar das contendas que os separavam no campo profissional, os magistrados em boa medida, também partidários de uma ordem jurídica liberal - e os advogados eram aliados políticos naturais. Não à toa, o slogan da UDN, neste momento, já era “todo poder ao Judiciário". ${ }^{203}$ Em seu discurso, Eduardo Gomes defendeu a entrega do poder ao presidente do STF argumentando que a autoridade do tribunal ancorava-se,

\footnotetext{
200 Jornal do Comércio, 20/10/1945, p. 4.

201 Jornal do Comércio, 20/10/1945, p. 4.

202 Jornal do Comércio, 20/10/1945, p. 4.

${ }^{203}$ BENEVIDES, Maria Victoria de Mesquita, op. cit., p. 25.
} 
não na Constituição Federal de 1937 (julgada ilegítima), mas na "nossa formação constitucional republicana". 204

$\mathrm{O}$ autor do discurso do brigadeiro (certamente, ele próprio, um bacharel ${ }^{205}$ ) sabia que as posições do candidato apresentadas para um público de bacharéis se fortaleceriam com argumentos extraídos da tradição jurídica brasileira (a partir de autores consagrados, como Rui Barbosa e Pedro Lessa, e das Constituições, sobretudo as de 1891 e 1934) e entre autores, episódios históricos e leis estrangeiras, especialmente francesas, inglesas e norte-americanas.

Na sessão de 23 de outubro, o Conselho Federal da OAB debateu o evento de apoio dos advogados a Eduardo Gomes. Pinto Lima saudou a "palavra oracular" do Brigadeiro. ${ }^{206} \mathrm{O}$ único questionamento interno à participação da $\mathrm{OAB}$ na organização do manifesto de apoio ao Brigadeiro de que se tem notícia foi registrada na sessão do Conselho do Distrito Federal de 17 de outubro de 1945. Neste dia, o conselheiro seccional Cid Braune disse que soubera pelos jornais sobre a existência da lista de adesões à candidatura de Eduardo Gomes (tratava-se do manifesto que seria entregue ao candidato dois dias depois) à disposição dos advogados na tesouraria do Conselho do Distrito Federal, que compartilhava as suas instalações com o Conselho Federal da OAB. Manifestou seu estranhamento em relação à notícia, pois sendo tesoureiro da seção, não tinha conhecimento do fato. "Disse mais que, não podendo exercer atividades políticas, não se justificaria a existência da lista na instituição. "207 É improvável que Cid Braune ignorasse o fato. De todo modo, ele aproveitou a ocasião para registrar o seu protesto solitário ao engajamento escancarado da OAB na campanha de Eduardo Gomes. Em resposta a Braune, Adauto Lúcio Cardoso, que também integrava a seção do Distrito Federal da OAB, admitiu que ele próprio colocara a lista

\footnotetext{
204 Jornal do Comércio, 20/10/1945, p. 4.

${ }^{205}$ John Dulles sugere que o discurso de Eduardo Gomes tenha sido redigido por Prado Kelly: "Eduardo Gomes, que contava com o auxílio de José Eduardo do Prado Kelly (filho do juiz Octavio Kelly) na elaboração dos seus discursos, fez um pronunciamento elevado, dirigindo-se à platéia de advogados dedicados à justiça e à liberdade. ” DULLES, John W. F, op. cit., p. 374.

${ }^{206}$ CF-OAB, Ata de sessão do Conselho Federal, 23/10/1945.

207 GUIMARÃES, Lúcia Maria Paschoal; BESSONE, Tânia. História da Ordem dos Advogados do Brasil. Criação, primeiros percursos e desafios (1930-1945), op. cit., p. 121.
} 
na tesouraria do órgão, "esclarecendo que o documento começara a correr em março, época em que a luta política apenas se iniciava. Tendo em vista as proporções tomadas, entendia que a lista devia ser retirada". 208

Em 30 de outubro de 1945, o Conselho Federal manifestou seu apoio entusiasmado à deposição de Getúlio Vargas pelo Exército. ${ }^{209}$ No mesmo dia, os conselheiros federais estiveram entre os poucos convidados à posse de José Linhares na presidência da República. ${ }^{210} \mathrm{~A}$ deferência foi um reconhecimento à centralidade do papel desempenhado pelo Conselho Federal no combate ao regime deposto. ${ }^{211}$

\section{5.) O Conselho Federal em busca de aliados na sociedade civil e no aparato estatal}

No curso de sua luta contra Vargas, a OAB procurou aliados na sociedade civil e mesmo no aparelho estatal. Antes de tudo, a Ordem pretendeu obter a adesão dos advogados para a sua causa. O apoio da categoria profissional traria uma vantagem inequívoca: oferecer lastro às posições do Conselho Federal, demonstrando que traduziam o pensamento dos advogados - um importante argumento de que se podia lançar mão no debate com os que apontavam a desvirtuação das finalidades do Conselho Federal e sua partidarização. Há indícios de que uma parte importante dos advogados tenha comungado das posições da OAB. Como já se disse, o número de signatários (eles próprios advogados do foro carioca) do manifesto entregue a Eduardo Gomes no Teatro Municipal variou de mil a dois mil, segundo a fonte. Constata-se que a adesão ao documento foi significativa, considerando-se que ele circulou apenas entre os advogados do Distrito Federal e o número de profissionais no país não ultrapassava, então, os 15 mil (ver Tabela 2). Para se avaliar a aderência da categoria profissional às iniciativas do grupo liberal, deve-se, também, considerar o número expressivo de subscrições de advogados aos dois pedidos de habeas corpus de 1944 e 1945 - já

\footnotetext{
${ }^{208}$ Ibidem, p. 121.

${ }^{209}$ CF-OAB, Ata de sessão do Conselho Federal, 30/10/1945.

${ }^{210}$ CF-OAB, Ata de sessão do Conselho Federal, 30/10/1945.

211 "Segundo relato de Sobral Pinto, só tiveram acesso à solenidade de posse os Ministros do STF e os Conselheiros do Conselho Federal da OAB, estes últimos em homenagem à luta desenvolvida pela instituição contra o Estado Novo." VENÂNCIO FILHO, Alberto. Notícia histórica da OAB, 1930-1980, op. cit., p. 73.
} 
mencionados neste trabalho - em favor de próceres udenistas. Igualmente, as manifestações de apoio de entidades de advogados, sobretudo Conselhos Seccionais da OAB e Institutos de Advogados, a moções do Conselho Federal fortaleciam as posições dos bacharéis liberais.

Não há qualquer indício de que a Ordem, no âmbito de sua luta contra o Estado Novo, tenha buscado tecer alianças com organizações das classes populares. $\mathrm{Na}$ realidade, estas permaneceram ausentes da batalha travada pelos liberais contra Vargas, assim como da campanha de Eduardo Gomes. ${ }^{212}$ Os trabalhadores politicamente ativos estavam comprometidos com o movimento queremista e com o PCB. A ampla mobilização dos trabalhadores urbanos que marcou os últimos meses do Estado Novo e foi tolerada pelo governo, intensificou os ataques a Vargas dos setores de elite oposicionistas. $^{213}$

Quando o Conselho Federal da OAB esboçou dirigir-se ao "povo", adotou uma posição elitista que pretendia "esclarecer" e guiar os trabalhadores. O chamamento era feito com prudência, pois os conselheiros federais temiam que a sedição que alimentavam saísse de seu controle e fosse apropriado pelas classes populares. Com efeito, os bacharéis liberais insistiam no caráter "moral" de seu combate e na natureza ordeira de sua luta, pois se gabavam de contar apenas com a oratória como arma contra

\footnotetext{
212 "A efervescência generalizada de vários grupos sociais contra o Estado Novo, naturalmente convergentes na campanha do Brigadeiro, permite considerar o movimento que desembocaria na criação da UDN como um movimento da sociedade civil, das camadas médias para cima." BENEVIDES, Maria Victoria de Mesquita, op. cit., p. 33. "A campanha [de Eduardo Gomes, em 1945] mobilizou é verdade, amplos setores das camadas médias, dos intelectuais, das Forças Armadas, mas não os trabalhadores; este povo permaneceu à parte da campanha feita, pelo menos teoricamente, em seu nome." Ibidem, p. 45. 213 "A intensa mobilização popular em torno das bandeiras queremistas (...) provocam os setores mais conservadores da oposição (...) E já em abril (...) a grande imprensa passa a dirigir suas críticas a Getúlio, não por ser um ditador, mas por 'não controlar a classe operária' e 'permitir que seu Ministro do Trabalho, Marcondes Filho, encorajasse as greves' (...) A anistia de abril, que beneficiaria Luis Carlos Prestes, e a legalização do Partido Comunista, em julho, consolida um fardo ameaçador para as forças conservadoras, com os maus presságios da aliança que se formava entre os comunistas, os 'queremistas' e os novos trabalhistas. A aproximação de Getúlio com o operariado e a conquista da esquerda comunista transformam-se em fator decisivo para abalar os interesses da burguesia, as convicções legalistas das Forças Armadas - que tão bem serviram ao regime, por tantos anos - e até mesmo os pilares da tradição liberal, anti-golpista por essência." BENEVIDES, Maria Victoria de Mesquita, op. cit., p. 55.
} 
um regime cujas ações semeariam a anarquia. ${ }^{214}$. Pretendiam desencadear uma "revolução dentro da ordem", ou seja, uma mudança de regime político respaldada pelo Judiciário e pelas Forças Armadas.

Segundo os conselheiros federais da OAB o combate a Vargas era uma obra de restauração - restauração de supostas tradições democráticas que datavam do Império. Pinto Lima, ao comemorar a realização do ato dos advogados em apoio a Eduardo Gomes, afirmou que os opositores do regime vigente devolviam "à pátria o seu antigo esplendor de civilização e de cultura democráticas no Império e na República. ${ }^{215} \mathrm{E}$ Milton Campos, no discurso elaborado para o mesmo evento, escreveu que o Brigadeiro garantia "o reatamento das tradições cívicas que vêm do Império. "216

No meio estatal, o Conselho Federal lançou apelos ao Judiciário, mas guardou o melhor de suas expectativas às Forças Armadas. A Ordem recorreu ao TSE qualificado pelo Conselho Federal como o "órgão incumbido de superintender o processo de reconstrução da Nação" ${ }^{217}$ para garantir a realização das eleições presidenciais (contra o queremismo) e a observação do calendário eleitoral (contra o Decreto-Lei n ${ }^{\circ}$ 8.063). ${ }^{218}$ Em outubro de 1945, Sobral Pinto foi designado pelo Conselho Federal para entregar pessoalmente ao presidente do TSE, “o único poder desarmado competente, que tem meios de opor barreiras à ilegalidade em marcha”, a moção aprovada contra a alteração da data das eleições estaduais. ${ }^{219}$

No decorrer do ano de 1945, o Conselho Federal interpelou os chefes militares para que garantissem a redemocratização do país. $O$ apelo às Forças Armadas desnudava o realismo político do Conselho Federal, convencido de que a derrocada do Estado Novo dependia do poder armado. ${ }^{220}$ Da moção proposta por Raul Fernandes, e

\footnotetext{
${ }^{214}$ CF-OAB, Ata de sessão do Conselho Federal, 16/10/1945. Diário de Notícias, 17/10/1945, $1^{\text {a }}$ seção, p. 3.

${ }^{215}$ CF-OAB, Ata de sessão do Conselho Federal, 23/10/1945.

${ }^{216}$ Jornal do Comércio, 20/10/1945, p. 3.

${ }^{217}$ CF-OAB, Ata de sessão do Conselho Federal, 16/10/1945. Diário de Notícias, 17/10/1945, $1{ }^{\text {a }}$ seção, p. 3 .

${ }^{218}$ CF-OAB, Atas de sessão do Conselho Federal, 2/10/1945 e 16/10/1945.

${ }^{219}$ DULLES. John W. F, op. cit., p. 371-372. CF-OAB, Ata de sessão do Conselho Federal, 16/10/1945.

${ }^{220}$ Como aponta Maria Victoria Benevides, o apelo aos militares ocupava, igualmente, um lugar central na estratégia udenista de combate a Vargas. Em junho de 1945, o presidente do partido, Otávio
} 
aprovada por todos os conselheiros federais, em que se aclamava a derrubada de Vargas, em 29 de outubro, constava o seguinte trecho: "Honra às Forças Armadas que, ainda uma vez, no curso da história, se mostraram compartes do nosso destino e servidoras da comunidade. ",221

\section{6.) O Conselho Federal frente ao governo Dutra}

Os primeiros anos de democracia, coincidentes com o período Dutra, representaram uma solução de compromisso entre as elites brasileiras. Na sua dimensão partidária, a aliança consubstanciou-se na aproximação entre o Partido Social Democrático (PSD) e a UDN. A OAB avalizou o pacto elitário e manifestou sua satisfação com a nomeação de seu presidente, Raul Fernandes, como chanceler do governo Dutra, no final de $1946 .^{222}$ Atento à ordem mundial que tomava nova conformação com o fim da Segunda Guerra Mundial, o Conselho Federal da Ordem apoiou o alinhamento incondicional do Brasil ao bloco capitalista liderado pelos Estados Unidos - que teve em Raul Fernandes um entusiasmado artífice - e aplaudiu o rompimento das relações diplomáticas do Brasil com a União Soviética, em 1947. ${ }^{223}$

$\mathrm{Na}$ presidência da OAB em virtude do licenciamento de Raul Fernandes, Pinto Lima comandou a adesão do Conselho Federal à política externa de Dutra. Assim, no dia 27 de maio de 1947, manifestou o seu apoio à aproximação diplomática do Brasil em relação a Argentina e ao Uruguai, reforçada pela visita realizada pelo presidente

\footnotetext{
Mangabeira, declarou: "Penso que as Forças Armadas estão no dever de intervir na atual situação brasileira. Vou adiante: é seu dever intervir (...) são as únicas forças que tem força real para acudir em defesa da nação." BENEVIDES, Maria Victoria de Mesquita, op. cit., p. 55.

${ }^{221}$ CF-OAB, Ata de sessão do Conselho Federal, 30/10/1945. O Jornal noticiou que o Conselho Federal, por ocasião da derrubada de Vargas, aprovou uma mensagem de congratulações às Forças Armadas. $O$ Jornal, 31/10/1945, $1^{\text {a }}$ seção, p. 3 .

${ }^{222}$ CF-OAB, Ata de sessão do Conselho Federal, 10/12/1946. Gerson Moura resumiu da seguinte maneira a política de Raul Fernandes à frente do Ministério das Relações Exteriores: "Desde 1947 o Itamaraty era chefiado por Raul Fernandes, jurista conservador, que se convencera de que a guerra entre Leste e Oeste era inevitável - e talvez desejável, como a única maneira de evitar a dominação bolchevista na Europa -, de modo que o Brasil deveria integrar uma 'frente ocidental unida' em torno dos EUA. Isso significava, evidentemente, seguir sem restrições o voto americano nas reuniões internacionais." MOURA, Gerson. Sucessos e ilusões: relações internacionais do Brasil durante e após a Segundo Guerra Mundial. Rio de Janeiro: Editora da Fundação Getúlio Vargas, 1991, p. 62.

${ }^{223}$ CERVO, Amado Luiz, BUENO, Clodoaldo. História da política exterior do Brasil. Brasília: Editora Universidade de Brasília, 2008, p. 269-273.
} 
brasileiro aos dois países vizinhos ${ }^{224}$ e, no dia 8 de julho, expressou seu contentamento com a visita do presidente chileno Gabriel González Videla ao Brasil. ${ }^{225}$ Em 19 de agosto, Pinto Lima congratulou-se com o Conselho Federal pela instalação da Conferência Interamericana para a Manutenção da Paz e da Segurança do Continente, solicitando que se anexassem à ata os discursos feitos por Dutra e Raul Fernandes na ocasião - o que foi unanimemente aprovado pelos conselheiros. ${ }^{226} \mathrm{Em} 2$ de setembro de 1947, novamente a pedido de Pinto Lima, o Conselho Federal aprovou um voto de regozijo pela chegada ao país do presidente norte-americano Harry Truman e pelo encerramento da Conferência Interamericana, que confirmou a hegemonia dos EUA sobre o continente americano. ${ }^{227}$

Finalmente, na sessão de 28 de outubro de 1947, o Conselho Federal da OAB aprovou, por iniciativa de Tertuliano Mitchel, um voto de aplauso a Dutra pelo rompimento das relações diplomáticas do Brasil com a União Soviética. E, ainda, aprovou um "desagravo e solidariedade ao Governo pela situação vexatória que o governo soviético impôs á delegação brasileira, mantida como refém no Hotel Nacional. "228

No plano interno, a entidade assistiu calada à duríssima repressão empreendida por Dutra contra o movimento sindical e o Partido Comunista Brasileiro (PCB). Entretanto, a truculência policial não demorou a vitimar também alguns membros da elite dos advogados. Já em setembro de 1946, denunciam-se, no Conselho Federal da $\mathrm{OAB}$, violências policiais praticadas contra Adauto Lúcio Cardoso, ex-conselheiro federal. O transbordamento do autoritarismo governamental para a categoria dos advogados obrigou a $\mathrm{OAB}$ a denunciá-lo como atentatório à ordem jurídica e às

\footnotetext{
${ }^{224}$ CF-OAB, Ata de sessão do Conselho Federal, 27/5/1947.

${ }^{225}$ CF-OAB, Ata de sessão do Conselho Federal, 8/7/1947.

${ }^{226}$ CF-OAB, Ata de sessão do Conselho Federal, 19/8/1947.

227 CF-OAB, Ata de sessão do Conselho Federal, 2/9/1947. Segundo Gerson Moura, a Conferência Interamericana de 1947 "espelhava a política dos EUA para a América Latina sob a batuta de Truman: 'preocupação pela segurança, determinação de manter a hegemonia política e econômica e a promoção de sua própria marca de democracia'." MOURA, Gerson, op. cit., p. 66.

${ }^{228}$ CF-OAB, Ata de sessão do Conselho Federal, 28/10/1947.
} 
liberdades individuais, abrindo uma frente de atrito entre a entidade e o governo Dutra, ainda que predominasse uma atitude de colaboração e conciliação. 


\section{CAPÍTULO II: A PAUTA CORPORATIVA DA DÉCADA DE 1950}

\section{1.) A nova agenda}

Desde o início da década de 1950, o Conselho Federal da OAB consagrou o melhor de seus esforços a uma pauta corporativa. A atuação concentrada em temas de interesse dos advogados deveu-se a uma combinação de fatores. $\mathrm{O}$ mais importante deles refere-se às mudanças sofridas pela categoria profissional em decorrência da modernização capitalista do país. É preciso também considerar que a dedicação à defesa da corporação (um dos objetivos fundamentais da Ordem, ao lado de suas atribuições de seleção e fiscalização dos advogados) decorreu da necessidade da OAB firmar seu papel como representante dos interesses da categoria profissional face ao surgimento de concorrentes para o cumprimento de tal tarefa, notadamente os sindicatos de advogados. Ademais, o regime democrático oferecia aos conselheiros federais amplos espaços de participação política, o que os dispensava de uma atuação partidarizada como ocorrera no biênio 1944-1945. A presença no Conselho Federal de elementos ligados ao PSD contrabalançava o domínio udenista no organismo. Finalmente, o cumprimento da agenda corporativa impunha ao Conselho Federal o reforço dos laços de colaboração com o Estado, especialmente com o governo federal e o Congresso Nacional.

Mas, como a política corria nas veias dos conselheiros federais, estes, vez por outra, romperam seu silêncio em relação à conjuntura política para condenarem atos do governo de Perón, na Argentina, ou violências policiais no Brasil. Paradoxalmente, neste período de ação "para dentro", o Conselho Federal foi presidido por homens estreitamente vinculados à vida política, como o senador e presidente do Partido Republicano (PR) Atílio Vivacqua, o ex-interventor potiguar e futuro ministro da Justiça Miguel Seabra Fagundes e o udenista José Eduardo do Prado Kelly. É certo que as credenciais políticas destes bacharéis, assim como suas relações com o mundo do poder, favoreciam o atendimento das demandas corporativas da OAB.

Por duas ocasiões, os bacharéis liberais que haviam combatido o Estado Novo fustigaram o governo Perón no Conselho Federal. Na raiz de sua aversão ao peronismo 
estava o entendimento de que este era a versão argentina do varguismo. Em 1951, Sobral Pinto fez um pronunciamento em solidariedade ao argentino Manuel Ordoñez, que estaria sendo perseguido pelo governo de seu país por sua atuação como advogado do jornal La Prensa. O conselheiro Claro Augusto de Godoi retorquiu que o assunto não era da alçada do Conselho Federal, mas sua posição foi largamente vencida. Em seguida, o órgão deliberou dirigir-se a Manuel Ordoñez e à Federação Argentina de Colégio de Advogados para manifestar sua solidariedade ao advogado argentino e também solicitar a intervenção do chanceler brasileiro no assunto e informar ao embaixador argentino no Brasil as providências tomadas pelo Conselho Federal em favor de Ordoñez. ${ }^{229}$ Cerca de dois anos depois, em outubro de 1953, Adauto Lúcio Cardoso voltou a falar de Ordoñez. Protestou contra a prisão do advogado pelo governo argentino e conseguiu que o Conselho Federal da OAB aprovasse, por unanimidade, uma moção em que o órgão manifestava "sua esperança de que, em favor da liberdade do advogado argentino MANUEL ORDOÑEZ, preso em Buenos Aires, por motivo de patrocínio da causa de GAINZA PAZ, diretor do jornal 'La Prensa', se mobilize a consciência jurídica das Américas." É interessante notar que Adauto Lúcio Cardoso procurou legitimar a intervenção do Conselho Federal no assunto com dois argumentos: 1.) o passado de luta do órgão contra o autoritarismo estadonovista; 2.) a preservação da ordem jurídica não se asseguraria por uma ação restrita aos limites do território nacional. Nesta segunda ocasião, nenhum conselheiro alegou que não caberia ao Conselho Federal se manifestar sobre a questão. ${ }^{230}$

Em abril de 1958, o conselheiro José Maria Mac Dowell da Costa, que integraria o Conselho Federal por praticamente todo o período democrático e fora promotor do Tribunal de Segurança Nacional (TSN) ${ }^{231}$, propôs um protesto contra o fechamento do Comitê Nacional das Câmaras de Advogados da Hungria pelo governo daquele país. A moção, aprovada pelo Conselho Federal, manifestava, entre outros pontos, votos para que o regime comunista fosse derrubado na Hungria, apresentando as esperanças de que

\footnotetext{
${ }^{229}$ CF-OAB, Ata de sessão do Conselho Federal, 3/4/1951.

${ }^{230}$ CF-OAB, Ata de sessão do Conselho Federal, 13/10/1953.

${ }^{231}$ GUIMARÃES, Lúcia Maria Paschoal, BESSONE, Tânia. História da Ordem dos Advogados do Brasil. Criação, primeiros percursos e desafios (1930-1945), op. cit., p. 281.
} 
voltasse a reinar no país "o verdadeiro Direito, a Justiça real, que, embora comprimidos sob férreo guante, jamais soçobram e acabam por se impor. "232

Porém, ao contrário do que se poderia esperar, devido ao antigetulismo dos últimos anos do Estado Novo, o Conselho Federal praticamente calou-se sobre a crise política de agosto de 1954. Ela foi apenas mencionada de maneira discreta nas sessões do Conselho Federal. No dia 10 de agosto, o conselheiro Mair Cerqueira protestou contra a subversão à ordem jurídica representada pelo atentado que vitimou o major Rubens Florentino Vaz. Os conselheiros João Otaviano de Lima Pereira e Osvaldo de Souza Valle lhe secundaram para bradar contra a "insegurança jurídica em que vivemos." ${ }^{233} \mathrm{Na}$ semana seguinte, um representante baiano no Conselho Federal, Paulo Barreto, leu um telegrama em que o presidente da OAB de seu estado, Gilberto Valente, lhe informava que aquela seção da Ordem aprovara um voto de solidariedade à Aeronáutica pelo assassinato do major Vaz e de protesto contra o atentado a Lacerda. ${ }^{234}$ Finalmente, na sessão de 31 de agosto, o Conselho Federal aprovou um voto de pesar pela morte de Vargas. ${ }^{235}$

O Conselho Federal acompanhou sobressaltado as mudanças que atingiram a advocacia a partir da década de 1950. Temeu pela proletarização da profissão - efeito indesejado do assalariamento dos advogados e da inflação de diplomas de Direito. O organismo apostou na redução do número de advogados, no alargamento do campo da advocacia e na implantação de dispositivos de proteção social para frear o processo de proletarização.

Ao tratar, em 1959, do projeto de previdência dos advogados em tramitação na Câmara dos Deputados, o conselheiro federal da OAB Carlos Bernardino de Aragão Bozano lamentou que os advogados se proletarizassem sem gozarem, em contrapartida, a proteção social assegurada aos trabalhadores urbanos. ${ }^{236}$ Em 1962, ocupando-se, também, da previdência social dos advogados, o conselheiro federal Letácio Jansen

\footnotetext{
${ }^{232}$ CF-OAB, Ata de sessão do Conselho Federal, 8/4/1958.

${ }^{233}$ CF-OAB, Ata de sessão do Conselho Federal, 10/8/1954.

${ }^{234}$ CF-OAB, Ata de sessão do Conselho Federal, 17/8/1954.

${ }^{235}$ CF-OAB, Ata de sessão do Conselho Federal, 31/8/1954.

${ }^{236}$ GUEIROS, Nehemias. A advocacia e o seu estatuto. Rio de Janeiro: Livraria Freitas Bastos, 1964, p. 184.
} 
alarmava-se com a situação de que um advogado-empregado pudesse receber um salário menor que um motorista da Câmara dos Deputados. ${ }^{237}$ Assumindo o posto de bâtonnier neste mesmo ano, Povina Cavalcanti comprometeu-se em adotar uma "terapêutica heróica" para enfrentar a proletarização da categoria profissional que passava a comandar:

"Deixei para o fim o dever de proclamar que a classe dos advogados do Brasil sofre, no seu espírito e na sua carne, a maior crise da sua história: a crise da sua proletarização, a qual necessitamos combater com todas as energias de que somos capazes. $O$ advogado, nas capitais, como no interior, salvo exceções, luta desesperadamente. Precisamos levar-lhe o nosso apoio e a nossa solidariedade. Proletário, sim, com o brilho do colarinho engomado se apagando no plenário dos tribunais ou nas audiências do juiz singular, o advogado é a maior vítima dessa inflação galopante, que nos ameaça a todos. Convoco os meus eminentes colegas do Conselho Federal para a mais séria, a mais dramática das nossas cogitações: a aplicação de uma terapêutica heróica, que restitua aos advogados a sua qualificação social. O Egrégio Conselho - é certo - não se tem descurado do assunto, honra lhe seja. Mas necessitamos fazer um pouco mais, algo de mais imediato, que redima a classe de sua proletarização. "238

O assalariamento progressivo dos advogados motivou o Conselho Federal a debater a proposta de um salário-mínimo para a profissão - à semelhança do que faziam os médicos, atingidos pelo mesmo processo que transformava os profissionais liberais típicos em empregados de empresas privadas ou do Estado. Em 1957, um projeto de Lei prevendo um piso salarial para os advogados foi apresentado à Câmara dos Deputados. $^{239}$

\footnotetext{
${ }^{237}$ Ibidem, p. 208.

${ }^{238}$ CF-OAB, Ata de sessão do Conselho Federal, 11/8/1962.

${ }^{239}$ CF-OAB, Atas de sessão do Conselho Federal, 22/11/1955, 27/8/1957, 15/5/1962 e 15/12/1964.
} 
Ao longo da década de 1950, os discursos de posse e despedida dos presidentes da OAB foram dominados pelos temas corporativos. Assim, ao entregar, em outubro de 1954, a direção do Conselho Federal a Miguel Seabra Fagundes, Atílio Vivacqua afirmou:

"Quando a advocacia, assim como as outras profissões liberais, sofre os duros efeitos de uma época tormentosa e desajustada, e quando as privações e misérias invadem inúmeros lares dos mourejadores do Foro, a nossa profissão não poderia deixar de inserir-se no quadro da politica social. "240

Na mesma ocasião, ao assumir o posto, Seabra Fagundes discursou:

"A defesa da classe, que a lei inclui ao lado da seleção e da disciplina como uma das funções da Ordem, não encontra, na lei mesma a que a ela alude, os instrumentos desejáveis de eficiência. Notadamente no que diz com a proteção social do advogado, pela pensão e pelo seguro. "241

O novo presidente, após comprometer-se com a luta pela proteção social para os advogados, discorreu sobre a condição econômica da categoria profissional:

"É mister não esquecer, que se o exercício da advocacia pode propiciar remunerações condignas, muitos profissionais há nos Estados e aqui mesmo, a maioria de certo, que dela mal retiram o indispensável. Somente uma minoria vive, hoje, ao abrigo das inquietações a que o curso da vida pode, de momento, lançar qualquer um de nós, pela impossibilidade de produzir. ${ }^{242}$

E arrematou:

${ }^{240}$ CF-OAB, Ata de sessão do Conselho Federal, 11/8/1954.

${ }^{241}$ CF-OAB, Ata de sessão do Conselho Federal, 11/8/1954.

${ }^{242}$ CF-OAB, Ata de sessão do Conselho Federal, 11/8/1954. 
"Já é tempo do trabalhador liberal reivindicar do Estado o tratamento, que uma visão parcial das atividades profissionais tem relegado à omissão. Isso não implica em dependência moral ou econômica do poder (...) senão no apelo a fórmulas que, pairando no campo do seguro social, se podem tornar extensivas ao advogado, como a quaisquer outros profissionais liberais, sem interferência com a autonomia que lhes é peculiar." 243

O temário das duas primeiras Conferências Nacionais da $\mathrm{OAB}$, realizadas em 1958 e 1960, privilegiou, igualmente, as questões vinculadas à defesa da advocacia. No seu discurso de posse no cargo de presidente da Ordem, proferido durante a $1^{\text {a }}$ Conferência Nacional, Alcino Salazar mostrou-se preocupado com as deficiências na formação acadêmica dos advogados, que ele relacionava à proliferação das faculdades de Direito, ao mesmo tempo em que responsabilizava o sistema de ensino jurídico vigente por tais falhas. O novo presidente advogava uma formação mais prática do advogado, atendendo aos reclamos das "novas condições da realidade contemporânea" e das "novas conquistas da ciência jurídica.", 244

As transformações ocorridas na categoria dos advogados, que constituem o pano de fundo do investimento do Conselho Federal da OAB numa pauta corporativa na década de 1950 foram estudadas, num trabalho pioneiro, por Olavo Brasil de Lima Júnior, Lúcia Klein e Antônio Martins. Nele, os autores analisam as repercussões impostas à categoria e à profissão de advogado pelo desenvolvimento capitalista brasileiro, a saber: a dificuldade de absorção dos advogados pelo mercado de trabalho em virtude da inadequação da formação recebida nas faculdades frente às necessidades do desenvolvimento econômico; modificações nas atividades profissionais dos advogados (assalariamento, migração dos advogados de escritórios de advocacias para

\footnotetext{
${ }^{243}$ CF-OAB, Ata de sessão do Conselho Federal, 11/8/1954.

${ }^{244}$ Anais da $1^{a}$ Conferência Nacional da Ordem dos Advogados do Brasil. Rio de Janeiro: Folha Carioca Editora, 1987, p. 556-557.
} 
grandes empresas privadas, advocacia preventiva ${ }^{245}$ ) e surgimento de novos ramos do Direito (denominados "modernos"), vinculados ao desenvolvimento capitalista. ${ }^{246} \mathrm{Um}$ conjunto de entrevistas realizadas com 102 participantes da IV Conferência Nacional da OAB, em 1970, constituiu a base empírica da pesquisa. Os entrevistados não foram escolhidos em termos de amostragem, pois os autores não puderam estabelecer um grupo representativo a partir de dados como idade, proveniência geográfica, e especialização em relação ao universo de participantes. ${ }^{247}$

No estudo, publicado em 1970, os autores apontam o fenômeno - que lhes era contemporâneo, ainda que já vigente no período democrático- de valorização das profissões de caráter técnico em prejuízo das profissões humanistas como decorrência do desenvolvimento capitalista. ${ }^{248}$ Este fenômeno acarretou tanto a substituição dos advogados em determinadas funções por profissionais técnicos, como administradores e economistas, quanto o emprego crescente de advogados em funções técnicas, sobretudo no caso de assalariados de grandes empresas.

O estudo faz uma distinção básica entre os ramos tradicionais e os modernos do Direito. Os advogados do primeiro ramo estavam mais próximos dos padrões tradicionais da profissão (advocacia contenciosa, condições de trabalho de um profissional liberal) e militavam em áreas como Direito Penal, Civil, Familiar ou Comercial. Os advogados do segundo ramo (Direito Administrativo, Fiscal, Financeiro, Tributário, Trabalhista, de Sociedade Anônima, de Propriedade Industrial, de Mercado) praticavam, especialmente, a advocacia preventiva e subordinavam-se, por vínculos de trabalho assalariado, a empresas privadas. Os autores observam ainda que estes novos ramos surgiram na esteira da expansão do setor industrial e de serviços. ${ }^{249}$ Os profissionais do ramo moderno do Direito trabalhavam, nas empresas, ao lado de administradores e economistas e as suas atividades assumiam crescentemente as

\footnotetext{
245 A advocacia preventiva ocupa-se, essencialmente, de atividades de consultoria e assessoria extrajudicial.

${ }^{246}$ LIMA JR., Olavo Brasil de, KLEIN, Lúcia Maria Gomes, MARTINS, Antônio Soares, op. cit., p. 7.

${ }^{247}$ Ibidem., p. 31.

${ }^{248}$ Ibidem, p. 6.

${ }^{249}$ Ibidem, p. 9.
} 
características de um trabalho técnico, entendendo-se técnicos como "simples implementadores de políticas. "250 A consequência era que os advogados das áreas mais recentes do Direito tendiam a se identificar com outros grupos profissionais - de caráter técnico -, com os quais partilhavam o cotidiano profissional, afastando-se de sua própria categoria profissional. ${ }^{251}$

Ademais, segundo o trabalho, os advogados dos ramos modernos, empregados de empresas privadas, tendencialmente, estavam mais sujeitos ao controle de seus patrões do que de sua categoria profissional. Os grupos dos advogados das áreas modernas encontravam-se internamente desorganizados e as entidades da categoria dos advogados permaneciam controladas pelos que militavam nos ramos tradicionais do Direito.

Entre os advogados entrevistados durante a pesquisa, $48 \%$ dedicavam-se aos ramos tradicionais, $17 \%$ aos ramos modernos e $33 \%$ a ambos. Os autores concluem que a profissão continuava dominada pelo padrão tradicional de advogado, ou seja, por aqueles que praticavam a advocacia contenciosa em área tradicional. Mas, os autores aventam a possibilidade de que o percentual de $33 \%$ dos entrevistados que se dedicavam a ambas as áreas poderia ser um indício do início de um maior afluxo de advogados para as áreas modernas. ${ }^{252}$ Entretanto, é bastante possível que o grupo de entrevistados pelos autores tivesse um perfil determinado. Eram advogados que participavam das diversas instâncias diretivas da $\mathrm{OAB}$ e de outras entidades profissionais $(63 \%$ dos entrevistados pertenciam ou haviam pertencido a diretorias de associações de classe ${ }^{253}$ ). Mesmo em relação àqueles que não ocupavam ou não tinham ocupado postos nestas entidades, pode-se cogitar que estivessem próximos das atividades corporativas, uma vez que participaram de uma conferência da OAB. Como as entidades de advogados, segundo os próprios autores, continuavam dominadas pelos que atuavam nos ramos tradicionais do Direito é normal que os entrevistados se

\footnotetext{
${ }^{250}$ Ibidem, p. 8-9.

${ }^{251}$ Ibidem, p. 9-10.

252 Ibidem, p. 29.

${ }^{253}$ Ibidem, p. 31.
} 
dedicassem a estas áreas. Dizendo de modo sucinto, a amostragem da pesquisa parece ter um claro viés de advocacia tradicional.

O estudo, igualmente, registra indícios de que o padrão tradicional de atividades dos advogados persistia, ao passo que o recrutamento destes profissionais, como assalariados, por empresas privadas ainda era baixo: $76 \%$ dos entrevistados trabalhavam em escritórios particulares, na burocracia estatal ou no Judiciário (Procuradoria e Magistratura). Além disto, os autores assinalam a predominância da acumulação de ocupações pelos advogados - uma característica tradicional da profissão - sobre a dedicação exclusiva, uma tendência nas empresas modernas, que preferiam empregar advogados em regime de dedicação integral. ${ }^{254}$ Também esta hipótese dos autores pode estar marcada pelo "viés tradicional" da amostragem.

Os autores propõem que a base social de recrutamento dos advogados era ampla, o que explicam por determinadas características do curso de Direito: grande número de vagas, cursos relativamente baratos e possibilidade de trabalhar durante o curso, já que os cursos não eram em tempo integral. ${ }^{255}$ Ademais, os autores sustentam esta tese com base em duas evidências empíricas. A primeira refere-se ao grau de instrução e à ocupação dos pais dos entrevistados. Os dados sobre a ocupação dos pais são os seguintes: 16\% eram ligados ao Direito (advogados, magistrados, procuradores ou tabeliões), $34 \%$ comerciantes, industriais ou proprietários rurais, $21 \%$ profissionais liberais ou tecnocratas e $23 \%$ burocratas ou trabalhadores manuais. De todo modo, predomina o recrutamento nas classes médias e alta, pois se somarmos os três primeiros grupos, teremos $71 \%{ }^{256}$ A segunda evidência empírica é o percentual de entrevistados (36\%) que ingressou no mercado de trabalho em ocupações estranhas à carreira de advogado, em funções de nível médio ou baixo. Tratava-se, possivelmente, de advogados que tiveram de trabalhar para manter-se durante o curso e que não contaram com o a apoio de parentes e amigos social e profissionalmente bem colocados para lhes

\footnotetext{
${ }^{254}$ Ibidem, p. 27.

255 Ibidem,, p. 24.

${ }^{256}$ Ibidem, p. 20.
} 
oferecer um posto ligado à sua área de formação. ${ }^{257}$ Os autores concluem o trabalho notando a existência de uma crise - causada pelo desenvolvimento capitalista - na profissão de advogado, permeada pelas seguintes questões: perda do prestígio social da profissão, concorrência feita por profissionais de áreas técnicas e inadequação da formação recebida frente às necessidades das empresas privadas. ${ }^{258}$

\section{2.) O novo estatuto da $O A B$}

Desde meados da década de 1940, o Conselho Federal debatia a elaboração de um novo estatuto para a Ordem. Em 1954, uma comissão composta pelos conselheiros federais Edgar de Toledo, Temístocles Marcondes Ferreira, Alberto Barreto de Melo e Nehemias Gueiros foi encarregada de elaborar um projeto de novo estatuto. No ano seguinte, esta comissão apresentou a sua proposta ao Conselho Federal, que a distribuiu para todas as seções estaduais da OAB. Depois de recolhidas as sugestões dos conselhos seccionais, uma nova comissão foi formada para preparar a segunda versão do projeto. Esta comissão era integrada pelos conselheiros federais Nehemias Gueiros (relator), Temístocles Marcondes Ferreira, Alberto Barreto de Melo, Carlos Bernardino de Aragão Bozano, Carlos Alberto Dunshee de Abranches e José Maria MacDowell da Costa. Ainda no primeiro semestre de 1956, o projeto de estatuto elaborado pela segunda comissão foi aprovado pelo Conselho Federal da OAB. ${ }^{259}$

Não havia dissenso entre os integrantes do Conselho Federal quanto à necessidade de se reformar o estatuto de 1933. No entanto, algumas divergências surgiram no momento em que os conselheiros federais discutiram o conteúdo do novo estatuto. Assim, o relator da comissão organizada em 1954, Edgar de Toledo, afastou-se da mesma por discordar dos outros integrantes em relação a uma questão crucial: a natureza da $\mathrm{OAB}$. Enquanto a maioria da comissão mostrava-se favorável à manutenção do caráter corporativo e da filiação obrigatória à Ordem, Toledo - numa posição que era

\footnotetext{
${ }^{257}$ Ibidem, p. 25.

${ }^{258}$ Ibidem, p. 54-56.

259 CF-OAB, Ata de sessão do Conselho Federal, 12/10/1948. Boletim da Ordem dos Advogados do Brasil, Rio de Janeiro, volume 1, número 1, outubro 1957, p. 33-34.
} 
francamente minoritária também no interior do Conselho Federal - a queria uma associação profissional de filiação facultativa. ${ }^{260}$

A reforma do estatuto da $\mathrm{OAB}$ pretendia dar conta das transformações pelas quais a advocacia passava. O projeto aprovado pelo Conselho Federal da Ordem, por exemplo, reconhecia a advocacia preventiva e assalariada, assim como o direito dos advogados à proteção social. O secretário-geral do Conselho Federal da $\mathrm{OAB}$, Alberto Barreto de Melo, justificava, no início de 1956, o imperativo de se atualizar o estatuto da Ordem aos novos tempos:

"A advocacia, obviamente, foi batida pelas transmutações do nosso tempo e pelos novos estilos de vida. É urgente adaptar a legislação reguladora da profissão às novas formas de vida, ao tipo de sociedade que se vem formando ao impacto dos acontecimentos. ${ }^{\prime 261}$

Do mesmo modo, a exposição de motivos do projeto de estatuto aprovado pelo Conselho Federal da Ordem reconhecia a necessidade de se ajustar as regras para o exercício da advocacia ao desenvolvimento do capitalismo brasileiro:

"O tempo e as solicitações dos diversos setores de atividades em que a advocacia tem vindo acompanhando o surto de desenvolvimento do País, encarregaram-se de demonstrar a necessidade da reforma fundamental dessa legislação [o estatuto de 1933 e outras leis que dispunham sobre a profissão de advogado] (...)."262

O novo projeto de estatuto visava, igualmente, dar uma solução - ainda que paliativa - ao problema da inflação dos diplomas em Direito, tornando mais rígidas as exigências para o ingresso na profissão e aumentando o rol das incompatibilidades para

\footnotetext{
${ }^{260}$ Boletim da Ordem dos Advogados do Brasil, Rio de Janeiro, volume 1, número 1, outubro 1957, p. 3334.

${ }^{261}$ CF-OAB, Ata de sessão do Conselho Federal, 3/4/1956.

${ }^{262}$ Boletim da Ordem dos Advogados do Brasil, Rio de Janeiro, volume 1, número 1, outubro 1957, p. 33.
} 
o exercício da advocacia. A exposição de motivos do projeto, contudo, não confessava tal motivação e justificava as medidas propostas em nome da manutenção da independência do advogado e do seu aperfeiçoamento profissional:

"A fim de tornar exeqüível o poder de seleção da Ordem, meramente técnico até agora, assegurando a manutenção de uma verdadeira consciência profissional e elevando, a mesmo tempo, o nível cultural da classe e a sua eficiência técnica, estabeleceu-se a exigência do estágio profissional como requisito para a inscrição no quadro dos advogados (...).”

“(...) o anteprojeto adotou o princípio de que a atividade da advocacia é incompatível com qualquer atividade, função ou cargo público que reduza a independência do profissional ou proporcione a captação de clientela (...). ,263

No entanto, meses depois, Nehemias Gueiros, ao assumir a presidência da OAB admitia que a criação do estágio e do Exame da Ordem pretendia enfrentar "o problema da multiplicação das nossas Faculdades de Direito, na verdade em número excessivo em relação à necessidade de formação das elites" e acrescentava que "já se tornava indispensável fazer uma distinção (...) a de que ser bacharel em Direito não é ser advogado. "264

Finalizada a proposta do novo estatuto, o Conselho Federal da $\mathrm{OAB}$ deu início à campanha para a transformação do projeto em lei. Ao longo de sete anos, o organismo fez gestões junto ao governo federal e ao Congresso Nacional, empenhando o prestígio político dos conselheiros federais. Porém, o acompanhamento da longa tramitação do projeto na Câmara dos Deputados e no Senado Federal demonstra que, tanto a regulamentação da advocacia, quanto as atribuições da $\mathrm{OAB}$ não eram matérias de interesse exclusivo dos advogados. O Conselho Federal da Ordem encontrou resistências ao seu projeto em setores politicamente poderosos, como a magistratura e a

\footnotetext{
${ }^{263}$ Boletim da Ordem dos Advogados do Brasil, Rio de Janeiro, volume 1, número 1, outubro 1957, p. 3637.

${ }^{264}$ CF-OAB, Ata de sessão do Conselho Federal, 11/8/1956.
} 
indústria paulista, que contavam com representação no Congresso e poder de pressão junto ao governo federal. ${ }^{265}$

Em junho de 1956, o presidente da OAB, Miguel Seabra Fagundes, acompanhado de um grupo de conselheiros federais, entregou ao ministro da Justiça o projeto do novo estatuto e solicitou que fosse enviado ao Congresso Nacional como projeto governamental. ${ }^{266} \mathrm{Em}$ agosto, Juscelino Kubitschek tornou-se o primeiro presidente da República a visitar a sede do Conselho Federal da OAB. Na ocasião, ele endossou o projeto do novo estatuto e mandou-o ao Congresso como projeto governamental. $^{267}$

Na Comissão de Constituição e Justiça da Câmara dos Deputados, o projeto foi relatado por Milton Campos, antigo dirigente da OAB. Neste período, o projeto recebeu numerosas emendas, provenientes de juízes, advogados e parlamentares. ${ }^{268}$ Destaque-se, por sua contundência e pela importância do cargo exercido pelo seu autor, o parecer do desembargador Delfino de Amorim Lima, presidente do Tribunal de Justiça de São Paulo, datado de novembro de 1958. Amorim Lima recusava a função de seleção e fiscalização da categoria dos advogados que o projeto confirmava à OAB. O desembargador reiterava o argumento empregado pelos opositores da Ordem desde o Império, segundo o qual a Constituição do país não permitia a existência de corporações de ofício, pois assegurava a liberdade profissional. Na realidade, o magistrado colocava em questão a própria existência da $\mathrm{OAB}$. No seu relatório, Milton Campos rejeitou a posição de Amorim Lima, reconhecendo a legalidade da atuação corporativa da OAB. Em primeiro lugar, afirmou que a Constituição Federal de 1946 estabelecia requisitos para o exercício das profissões. Em segundo lugar, argumentou que a mesma

\footnotetext{
${ }^{265}$ Não encontrei qualquer informação sobre uma oposição dos rábulas ao projeto de novo estatuto elaborado pelo Conselho Federal, que restringiu significativamente sua atividade profissional. Entretanto, suponho que eles tenham se mobilizado para defender os seus interesses, contando mesmo com a simpatia de alguns parlamentares. De todo modo, é certo que o apoio político que os rábulas podiam angariar não pode ser comparado com aquele de que a magistratura e a burguesia industrial dispunham.

${ }^{266}$ CF-OAB, Atas de sessão do Conselho Federal, 8/5/1956 e 19/6/1956.

${ }^{267}$ CF-OAB, Ata de sessão do Conselho Federal, 11/8/1956.

${ }^{268}$ Boletim da Ordem dos Advogados do Brasil, Rio de Janeiro, volume 2, número 4, abril 1958, p.1.
} 
constituição reconhecia a existência da Ordem ao incluí-la entre os organismos que deviam participar dos concursos de acesso à magistratura. ${ }^{269}$

No início de 1957, ao apresentar o seu relatório à Comissão de Constituição e Justiça da Câmara dos Deputados, Milton Campos revelou ter mantido estreito contato com o Conselho Federal durante a preparação de seu parecer, contando inclusive com a colaboração do Conselho na revisão do projeto original, apresentado, em seguida, à Comissão de Constituição e Justiça. ${ }^{270}$ No final de 1957, o Conselho Federal da OAB formou uma comissão incumbida de atuar junto ao Congresso Nacional e ao ministro da Justiça para obter uma rápida tramitação do projeto. O presidente da Ordem, Nehemias Gueiros, pretendia encerrar o seu mandato, em agosto de 1958, com a aprovação do novo estatuto. $^{271}$

Em maio de 1959, o Conselho Federal da OAB tomou conhecimento do telegrama enviado ao presidente da Câmara dos Deputados pela Federação das Indústrias de São Paulo e pelo Centro das Indústrias de São Paulo manifestando suas objeções ao projeto do novo estatuto da $\mathrm{OAB}$, que resolveu agir em defesa de sua proposição. O conselheiro federal da $\mathrm{OAB}$ e deputado federal Clóvis Ferro Costa foi incumbido "de levar àquela Casa do Congresso [a Câmara] o pensamento do Conselho sobre o referido Projeto de lei. ${ }^{1272}$

As articulações do Conselho Federal para a aprovação do novo estatuto seguiram pela presidência de Alcino Salazar que, ainda em maio de 1959, encontrou-se com o deputado José Bonifácio, primeiro secretário da Câmara dos Deputados, solicitando rapidez na tramitação do projeto do novo estatuto. ${ }^{273}$ É possível que tenha aproveitado a

\footnotetext{
${ }^{269}$ BASTOS, Aurélio Wander, op. cit., p. 320-324.

${ }^{270}$ VENÂNCIO FILHO, Alberto. Notícia histórica da OAB, 1930-1980, op. cit., p. 103.

${ }^{271}$ CF-OAB, Atas de sessão do Conselho Federal, 26/11/1957 e 15/4/1958. Apesar de seus esforços, Nehemias Gueiros não conseguiu ver o novo estatuto aprovado na sua gestão. Em entrevista concedida a Alberto Venâncio Filho, em 1981, Alberto Barreto de Melo, secretário-geral da OAB no pós-1945, confirmou o lobby realizado por Gueiros junto ao Congresso Nacional: "Também assinala Alberto Barreto de Melo que Nehemias Gueiros realizou importante trabalho de acompanhamento do projeto no Congresso Nacional, evitando que fosse desvirtuado ou deformado. Entretanto, houve necessidade de transações e conclui Alberto Barreto de Melo: 'O Estatuto tem muito compromisso político.' " VENÂNCIO FILHO, Alberto. Notícia histórica da OAB, 1930-1980, op. cit., p. 102.

${ }^{272}$ CF-OAB, Ata de sessão do Conselho Federal, 19/5/1959.

${ }^{273}$ CF-OAB, Ata de sessão do Conselho Federal, 26/5/1959.
} 
ocasião para defender o projeto elaborado pelo Conselho Federal dos ataques da indústria paulista.

Ainda na Câmara dos Deputados, o projeto foi encaminhado a um outro ilustre bacharel udenista, o deputado Pedro Aleixo. Este parlamentar também parece ter mantido contato com o Conselho Federal da $\mathrm{OAB}$ enquanto redigia o seu parecer. Assim, em novembro de 1959, o presidente da Ordem Alcino Salazar comunicou ao Conselho Federal que recebera uma carta de Pedro Aleixo com informações sobre o parecer que enviara à Comissão de Constituição e Justiça da Câmara. ${ }^{274}$

Já sob a presidência de José Eduardo Prado Kelly, Carlos Alberto Dunshee de Abranches apresentou ao Conselho Federal o seu protesto contra modificações feitas no projeto de estatuto, que diziam respeito aos atos privativos do advogado, pelo deputado Pedro Aleixo. O conselheiro federal solicitou a Prado Kelly (udenista como Aleixo) que se dirigisse à Câmara dos Deputados para postular que o estatuto fosse aprovado nos termos em que fora elaborado pelo Conselho Federal. O presidente da Ordem concordou com o pedido de Dunshee de Abranches - reforçado pelo conselheiro federal Aragão Bozano -, comprometendo-se a redigir ofícios ao presidente da Câmara e aos líderes dos partidos solicitando apoio para "as sugestões vitoriosas no Conselho, nas diferentes oportunidades em que a matéria foi debatida. "275

Em fins de 1960, o projeto foi aprovado pela Câmara dos Deputados e encaminhado ao Senado. Na Comissão de Constituição e Justiça desta casa, a relatoria do projeto coube ao senador Aloísio de Carvalho Filho. ${ }^{276}$ Presente à sessão do Conselho Federal da OAB de 12 de junho de 1962, o ex-conselheiro federal e expresidente da seção alagoana da Ordem, senador Afrânio Lages comprometeu-se a requerer urgência na votação do projeto a fim de obter uma rápida tramitação no Senado. Na mesma sessão, o conselheiro Aragão Bozano "deplorou que o parecer do Senador Aloísio de Carvalho Filho desfigurasse o projeto do Estatuto elaborado por este Conselho, retirando, inclusive, o capitulo sobre férias do advogado." O

\footnotetext{
${ }^{274}$ CF-OAB, Ata de sessão do Conselho Federal, 24/11/1959.

${ }^{275}$ CF-OAB, Ata de sessão do Conselho Federal, 25/10/1960.

${ }^{276}$ CF-OAB, Ata de sessão do Conselho Federal, 29/11/1960. VENÂNCIO FILHO, Alberto. Notícia histórica da OAB, 1930-1980, op. cit., p. 103-104.
} 
conselheiro Gaston Luís do Rego respondeu-lhe que o conteúdo original do projeto poderia ser restaurado no plenário do Senado. ${ }^{277}$

Aprovado no Senado, o projeto foi encaminhado ao presidente da República João Goulart, que o sancionou com um único veto, suprimindo o artigo 149 do projeto. Este artigo estabelecia que os advogados já inscritos na $\mathrm{OAB}$ não seriam atingidos pelos impedimentos de exercício da profissão previstos pelo novo estatuto. O governo justificou o veto presidencial em nome da igualdade no tratamento de integrantes de uma mesma categoria profissional. Em resposta, a OAB mobilizou-se para derrubar o veto presidencial no Congresso Nacional, defendendo o artigo suprimido fundamentalmente com o argumento de que os advogados já inscritos gozavam de direitos adquiridos para exercerem o ofício sob as regras anteriores. A démarche da Ordem dos Advogados acabou vitoriosa, pois o artigo 149 foi mantido pelo Congresso Nacional. $^{278}$

Em junho de 1963, o Conselho Federal promoveu uma sessão especial para comemorar o início da vigência do novo estatuto. Além da presença dos conselheiros federais e de dirigentes de outras entidades de advogados, o evento contou com a participação dos presidentes do Tribunal de Justiça da Guanabara e da Associação dos Procuradores da Guanabara, entre outras "pessoas gradas", na expressão da ata da sessão. O orador do evento foi Nehemias Gueiros, escolhido em reconhecimento à sua liderança no processo de reforma do estatuto da Ordem. ${ }^{279}$

\section{3.) A previdência social dos advogados}

A partir de 1937, as seções estaduais da Ordem começaram a organizar Caixas de Assistência dos Advogados destinadas a conceder auxílios aos advogados tornados

\footnotetext{
${ }^{277}$ CF-OAB, Ata de sessão do Conselho Federal, 12/6/1962.

${ }^{278}$ GUEIROS, Nehemias, op. cit., p. 286, 301-308. Nehemias Gueiros escreve a propósito do veto presidencial ao artigo 149 do novo estatuto da OAB: "Este artigo foi vetado pelo presidente da República, mas teve o veto rejeitado por esmagadora maioria de votos, contribuindo decisivamente para essa rejeição o prestante 'lobby' desenvolvido pessoalmente pelo Presidente do Conselho Secional da Ordem em Pernambuco, dr. José Cavalcanti Neves, junto aos membros do Congresso Nacional (...) $O$ Presidente Povina Cavalcanti, em nome de toda a classe, dirigiu-se, também, ao Congresso Nacional, postulando a rejeição do veto (...)."'GUEIROS, Nehemias, op. cit., p. 286.

${ }^{279}$ CF-OAB, Ata de sessão do Conselho Federal, 11/6/1963.
} 
inválidos e às famílias de advogados mortos. ${ }^{280}$ Este mecanismo de solidariedade corporativa revelou-se insuficiente e, já no início da década de 1950, o Conselho Federal da OAB debatia planos de proteção social aos advogados avalizados pelo Estado. O debate provocou profunda discórdia na elite dos advogados do país e pôs à prova a cultura do consenso cultivada pelo Conselho Federal da OAB. Até o final da década de 1950, duas correntes de opinião se confrontaram na discussão sobre a previdência dos advogados. A primeira aglutinava-se em torno do projeto de lei apresentado, em meados de 1953, pelo deputado petebista Lúcio Bittencourt à Câmara dos Deputados. Em síntese, a proposta concedia aos advogados e práticos uma aposentadoria custeada pelo Tesouro Nacional e gerida por um organismo do sistema previdenciário nacional, o Instituto de Previdência e Assistência dos Servidores do Estado (IPASE). ${ }^{281}$ Ao justificar o projeto, o parlamentar lembrava que os advogados, ao contrário dos juízes e membros do Ministério Público, encontravam-se desamparados em termos de proteção social e argumentava que eles mereciam o privilégio de terem sua aposentadoria financiada pelo Estado porque desempenhavam uma função pública, ao contribuírem para a manutenção da ordem jurídica. ${ }^{282}$ A segunda corrente era liderada por Carlos Alberto Dunshee de Abranches, membro do Conselho Federal da $\mathrm{OAB}$, que elaborou um plano prevendo a unificação das Caixas de Assistência dos Advogados estaduais num único organismo previdenciário a ser dirigido pela Ordem dos Advogados. Em 1954, o deputado pessedista Adroaldo Mesquita da Costa, conselheiro federal da OAB desde 1951, transformou a proposta de Dunshee de Abranches em projeto de lei apresentado, como o de Lúcio Bittencourt, à Câmara dos Deputados. ${ }^{283}$ Cada uma das posições procurou sustentação no Congresso Nacional e sua luta permaneceu equilibrada ao longo da década. ${ }^{284}$

\footnotetext{
${ }^{280}$ GUEIROS, Nehemias, op. cit., p. 147-153.

281 É possível que a vinculação dos advogados ao IPASE, proposta por Lúcio Bittencourt, tenha sido parcialmente responsável pelas resistências encontradas pelo seu projeto de lei no seio da elite profissional. A UDN acusava os Institutos de Previdência de serem politicamente controlados pelo PTB. BENEVIDES, Maria Victoria de Mesquita, op. cit., p. 188.

${ }^{282}$ GUEIROS, Nehemias, op. cit., p. 158-159.

${ }^{283}$ Ibidem, p. 160-163.

${ }^{284}$ Durante a gestão de Nehemias Gueiros, a OAB contratou um seguro privado para atender seus filiados. A expressiva adesão dos advogados ao seguro é prova de que o acesso à previdência social era, de fato,
} 
Ainda em 1953, o Conselho Federal da OAB encarregou os conselheiros federais Letácio Jansen e Edgar de Toledo, assim como o secretário-geral Alberto Barreto de Melo, de examinarem o projeto Lúcio Bittencourt. Reunidos em comissão decidiram recomendar o apoio do Conselho Federal à proposta. ${ }^{285} \mathrm{O}$ projeto Lúcio Bittencourt, apesar de aprovado em algumas comissões da Câmara dos Deputados, logo encontrou franca oposição do governo federal, em razão da fonte de recursos estabelecida para o pagamento das aposentadorias. Em parecer datado de 1954, um técnico do Ministério da Fazenda afirmava que aprovar o projeto seria "onerar de maneira impraticável o Tesouro, no pagamento de proventos a pessoas estranhas ao seu quadro de funcionários" e que, uma vez aprovado, abriria um precedente para que outras categorias de profissionais liberais pleiteassem o mesmo benefício. ${ }^{286}$

Como faltava consenso no Conselho Federal a respeito do modelo previdenciário a ser adotado para os advogados, a comissão responsável pela elaboração do projeto de novo estatuto da $\mathrm{OAB}$, rejeitando a proposição de Dunshee de Abranches, decidiu não tratar do tema. Ainda assim, incluiu, no documento, a assistência social entre os direitos dos advogados - o que foi preservado no artigo 89 do estatuto aprovado em 1963. ${ }^{287}$ Em seguida, o Conselho Federal decidiu encomendar ao mesmo grupo de conselheiros a elaboração de um plano previdenciário. Em fins de 1957, a comissão apresentou uma proposta calcada no plano Dunshee de Abranches. Ao contrário do estabelecido no projeto Lúcio Bittencourt, o grupo de conselheiros federais propôs que o custeio da previdência fosse repartido entre advogados, clientes e Estado. ${ }^{288}$ De todo modo, apenas no início de 1958, o Conselho Federal da OAB tomou partido, pela primeira vez, sobre a questão. No dia 29 de abril daquele ano, o Conselho recebeu a visita dos deputados Milton Campos e Aliomar Baleeiro, respectivamente, relatores do

uma prioridade para a categoria profissional. Em abril de 1958, menos de um ano após a contratação do seguro, cerca de três mil advogados (mil apenas no Distrito Federal), ou seja, aproximadamente $10 \%$ do total de profissionais atuantes no Brasil, havia aderido ao seguro. CF-OAB, Atas de sessão do Conselho Federal, 30/8/1955, 21/5/1957 e 1/4/1958.

${ }^{285}$ CF-OAB, Ata de sessão do Conselho Federal, 8/9/1953.

286 GUEIROS, Nehemias, op. cit., p. 170.

${ }^{287}$ GUEIROS, Nehemias, op. cit., p. 164-166; Boletim da Ordem dos Advogados do Brasil, Rio de Janeiro, volume 1, número 1, outubro 1957, p. 38.

${ }^{288}$ GUEIROS, Nehemias, op. cit., p. 166-170; CF-OAB, Ata de sessão do Conselho Federal, 1/4/1958. 
projeto de lei Lúcio Bittencourt na Comissão de Finanças e de Justiça da Câmara dos Deputados. Na ocasião, Aliomar Baleeiro pediu que o organismo manifestasse sua preferência a respeito da fonte de recursos para a previdência dos advogados. Venceu, por larga margem de votos (onze a três), a posição de que ela deveria ser suprida pelas Caixas de Assistência, como previa o projeto de Adroaldo Mesquita da Costa, e não pelo Tesouro, como estabelecia o projeto Bittencourt. ${ }^{289}$

Vitoriosa no Conselho Federal, a proposta de Dunshee de Abranches sofreu um importante revés, poucos meses depois, durante a $1^{\mathrm{a}}$ Conferência Nacional da OAB. A sessão do encontro dedicada à previdência dos advogados foi marcada pelo tumulto e por discussões ríspidas entre seus participantes. O relator do tema na Conferência foi o próprio Dunshee de Abranches, que, no trabalho apresentado, reafirmou sua conhecida posição. Ele defendeu a proposta de organização de um organismo previdenciário gerido pelos próprios advogados sob o argumento de que esta medida os livraria de interferências estatais, preservando, assim, sua liberdade - requisito necessário para o exercício da profissão. E investiu contra o projeto Lúcio Bittencourt, afirmando que o sistema previdenciário estatal era ineficaz. Além disto, classificou de imoral e ilegal a iniciativa para se estabelecer o Tesouro Nacional como pagador das aposentadorias dos advogados. ${ }^{290}$ Numa provocação que causou pronta agitação entre os participantes da sessão, Dunshee de Abranches declarou: "E por ele [projeto Bittencourt] a Nação, discriminadamente, iria pagar a aposentadoria de uma classe, de uma casta, de uma categoria. "291 No entanto, o debate que se seguiu à leitura do trabalho do relator foi dominado pelos partidários do projeto Bittencourt, os quais arrimaram sua posição em dois pontos: 1) a utilização de um instituto de previdência já existente ao invés da criação de uma nova estrutura administrativa onerosa para cuidar da previdência dos advogados; 2) o caráter especial do métier do advogado justificaria o privilégio de terem sua aposentadoria paga pelo Estado. ${ }^{292}$ Assim, Gaston Luís do Rego, que ingressaria no

\footnotetext{
${ }^{289}$ CF-OAB, Ata de sessão do Conselho Federal, 29/4/1958; GUEIROS, Nehemias, op. cit., p. 170-171.

${ }^{290}$ Anais da $1^{a}$ Conferência Nacional da Ordem dos Advogados do Brasil, op. cit., p. 396-400, 404, 410, 412-417.

${ }^{291}$ Ibidem, p. 415.

${ }^{292}$ Ibidem, p. 399-414
} 
Conselho Federal da OAB em 1962, afirmou que "os advogados estão entrosados no organismo judiciário - constituem órgão da Justiça, exercem função eminentemente pública (...). ${ }^{, 293}$ E José Cavalcanti Neves, presidente da seção pernambucana da Ordem, na sua intervenção, negou a imoralidade do projeto: "Não encontro motivos de ordem moral para que a classe recuse esse chamado privilégio. Se querem instituir esse privilégio - porque outra classe não o tem - não temos o direito de, falando como delegados de advogados dos Estados, recusá-lo (...). "294 Finalmente, os participantes da sessão aprovaram uma moção na qual expressavam seu apoio ao projeto de lei elaborado por Lúcio Bittencourt. ${ }^{295}$

Em outubro de 1959, o relator do projeto Bittencourt na Comissão de Legislação da Câmara dos Deputados, Aarão Steinbruch, do PTB, participou de uma reunião no Conselho Federal da OAB. Pouco depois, elaborou seu relatório, com base na proposta Dunshee de Abranches, que se transformou num projeto substitutivo. ${ }^{296} \mathrm{O}$ conselheiro Carlos Bernardino de Aragão Bozano foi encarregado pelo Conselho Federal de examinar o substitutivo de Steinbruch. Ao fazê-lo, rejeitou o substitutivo e renovou seu apoio ao projeto de Lúcio Bittencourt, do qual era conhecido partidário. Aragão Bozano refutou objeções a este projeto, detendo-se, especialmente, naquela que acusava a proposta de imoral, ao dispor de recursos do Tesouro em proveito de uma categoria profissional. $^{297} \mathrm{O}$ conselheiro federal retomou o argumento original de Bittencourt sobre a especificidade do ofício do advogado:

"O advogado é elemento essencial à distribuição da justiça; sem ele faltaria à Nação a ordem jurídica, sem ela desapareceria a segurança dos direitos, base das instituições vigentes. Não é possível a administração da justiça sem os advogados."

\footnotetext{
293 Ibidem, p. 400.

${ }^{294}$ Ibidem, p. 406.

295 Ibidem, p. 420.

${ }^{296}$ GUEIROS, Nehemias, op. cit., p. 176-178; CF-OAB, Ata de sessão do Conselho Federal, 20/10/1959.

${ }^{297}$ GUEIROS, Nehemias, op. cit., p. 178-184.
} 
“(...) A classe dos advogados apresenta características singulares, próprias, que não a permitem confundir-se com as outras classes de profissionais liberais. Os advogados são auxiliares da justiça. A lei que criou o seu órgão de classe atribuiu-lhe, expressamente, em seu artigo $2^{\circ}$, o exercício de função pública. Não encerra desigualdade o tratar desigualmente pessoas ou coisas desiguais. ${ }^{298}$

Em novembro de 1959, o Conselho Federal aprovou o parecer de Aragão Bozano e manifestou seu apoio ao projeto Lúcio Bittencourt. Como se vê, em menos de dois anos, a correlação de forças entre as duas correntes se invertera no Conselho Federal e favorecia, agora, os adversários da proposta Dunshee de Abranches. ${ }^{299}$ Em meados do ano seguinte, o presidente da OAB, Alcino Salazar, reuniu-se, no gabinete do presidente do Senado, com alguns senadores, dentre os quais o seu antecessor Atílio Vivacqua. Na ocasião, apresentou críticas ao substitutivo Steinbruch, que, aprovado na Câmara dos Deputados, tramitava, então, no Senado. ${ }^{300}$

O equilíbrio de forças entre as duas posições que planejavam, no interior da categoria profissional, a previdência dos advogados, foi rompido pelo surgimento de um tertius. A iniciativa coube à elite dos advogados de São Paulo. As três principais entidades de advogados do estado, a seção paulista da OAB, o Instituto dos Advogados de São Paulo e a Associação dos Advogados de São Paulo (AASP) já haviam negociado com o governo estadual uma lei previdenciária para os advogados paulistas. ${ }^{301}$ Prestigiadas por esta conquista, em 1960, as entidades encaminharam ao Conselho Federal da Ordem um projeto de previdência para os advogados de todo o país, cujos principais pontos eram: 1) a constituição de uma carteira autônoma para os advogados no IPASE; 2) a fiscalização desta carteira pela OAB; 3) a gestão da previdência dos advogados pelo IPASE; 4) todos os inscritos na OAB e seus dependentes seriam beneficiários; 5) os benefícios consistiriam em aposentadoria (por idade ou invalidez) e

\footnotetext{
${ }^{298}$ Ibidem, p. 180.

299 Ibidem, p. 184

${ }^{300}$ CF-OAB, Ata de sessão do Conselho Federal, 28/6/1960 GUEIROS, Nehemias, op. cit., p. 185.

${ }^{301}$ Anais da $2^{a}$ Conferência Nacional da Ordem dos Advogados do Brasil, op. cit., p. 180-181.
} 
pensão; 6) a preservação das Caixas de Assistência dos Advogados para concessão de benefícios suplementares; 7) o custeio da previdência dividido entre advogados, clientes e Estado. $^{302}$

A $2^{\mathrm{a}}$ Conferência Nacional da OAB consagrou o projeto paulista. No encontro, a comissão que tratou da questão previdenciária rejeitou o substitutivo Steinbruch e endossou, com poucas emendas, o plano das entidades paulistas. ${ }^{303}$ Entretanto, com a promulgação da Lei Orgânica da Previdência Social, em 1960, a elite dos advogados perdeu - ainda que temporariamente - a capacidade de moldar a previdência de sua categoria profissional de acordo com seus desígnios, pois a lei tornou o seguro social obrigatório para os advogados e os vinculou ao Instituto de Aposentadoria e Pensões dos Comerciários (IAPC). Entre os benefícios que ela garantia aos advogados e seus dependentes estavam aposentadoria, pensão e assistência médica. ${ }^{304}$

A elite dos advogados, agora razoavelmente aglutinada em torno de um modelo previdenciário comum ${ }^{305}$, mobilizou-se para fazer aprovar uma lei específica para sua categoria profissional. Com tal objetivo, apresentou ao Congresso Nacional, pelas mãos do senador udenista Venâncio Igrejas, o projeto elaborado pelas entidades paulistas. Em novembro de 1961, o presidente da OAB, José Eduardo Prado Kelly, dirigiu-se ao presidente da Câmara dos Deputados para solicitar a aprovação do projeto Igrejas, que tramitava naquela casa ${ }^{306}$ e incumbiu Nelson Carneiro, conselheiro federal da OAB e deputado federal pelo PSD, de acompanhar a tramitação do projeto Igrejas no

\footnotetext{
${ }^{302}$ Ibidem, p. 183-193.

303 Ibidem, p. 178-193, 349. O projeto das entidades paulistas e as emendas da conferência estão reproduzidos em: Anais da $2^{a}$ Conferência Nacional da Ordem dos Advogados do Brasil, op. cit., p. 188$193,349$.

${ }^{304}$ GUEIROS, Nehemias, op. cit., p. 189-196.

${ }^{305}$ Note-se que o consenso forjado, na elite dos advogados, em torno do projeto paulista foi relativo. Talvez o mais adequado seja compreender o projeto paulista como derivado de uma posição que se fez hegemônica no início da década de 1960, mas comportava contestações. Assim, em novembro de 1963, Nehemias Gueiros apresentou ao Conselho Federal da OAB uma proposta para que o órgão pleiteasse a revogação da lei de previdência dos advogados (fundada no projeto paulista) para que a categoria profissional voltasse a ser enquadrada na Lei Orgânica da Previdência Social. Segundo o ex-presidente da Ordem, esta última era mais benéfica aos advogados, pois os valores das aposentadorias previstos eram maiores e os benefícios concedidos em maior número. GUEIROS, Nehemias, op. cit., p. 217, 222-226.

${ }^{306}$ CF-OAB, Ata de sessão do Conselho Federal, 21/11/1961; GUEIROS, Nehemias, op. cit., p. 209.
} 
Congresso Nacional. ${ }^{307}$ Aprovado o projeto pelo Legislativo, Prado Kelly propôs uma moção, unanimemente aprovada pelo Conselho Federal da $\mathrm{OAB}$, que se iniciava da seguinte maneira:

"O Conselho Federal da Ordem dos Advogados do Brasil congratula-se com os Poderes da República pela compreensão revelada na instituição, por lei, da aposentadoria dos advogados. Esta corporação não desfrutava ainda os benefícios da previdência social, assegurados pela Constituição a todas as categorias profissionais, sem distinção entre o trabalho manual ou técnico e o trabalho intelectual. A medida legislativa, agora adotada, faz justiça a uma classe que tem influído decisivamente na evolução do Estado, na prática do Direito e no aprimoramento da ordem jurídica. ,308

Na conclusão, a moção apelava para que Goulart e seu Primeiro-ministro sancionassem o projeto de lei. ${ }^{309} \mathrm{Na}$ sessão seguinte, o conselheiro Letácio Jansen manifestou ao Conselho Federal da $\mathrm{OAB}$ temor de que o governo fizesse vetos ao projeto de lei de Venâncio Igrejas, em virtude das discordâncias ainda existentes no interior da categoria dos advogados quanto ao tema da previdência social. A conselheira Maria Rita Soares de Andrade respondeu-lhe que soubera que o procurador-geral da República, Evandro Lins e Silva, assegurara ao presidente da seção da OAB da Guanabara, Raul da Cunha Ribeiro, que o governo não pretendia opor vetos ao projeto. Por sua vez, Prado Kelly relatou aos conselheiros que enviara telegramas ao governo federal e aos presidentes da Câmara dos Deputados e do Senado pleiteando a sanção do projeto aprovado pelo Congresso Nacional. ${ }^{310}$

Finalmente, em meados de 1962, o projeto Igrejas foi promulgado, constituindo a Lei $\mathrm{n}^{\text {o }} 4.103-\mathrm{A} .{ }^{311} \mathrm{Na}$ realidade, a lei reproduzia, com pouquíssimas alterações, o

\footnotetext{
${ }^{307}$ CF-OAB, Ata de sessão do Conselho Federal, 24/7/1962.

${ }^{308}$ CF-OAB, Ata de sessão do Conselho Federal, 5/6/1962.

${ }^{309}$ CF-OAB, Ata de sessão do Conselho Federal, 5/6/1962.

${ }^{310}$ CF-OAB, Ata de sessão do Conselho Federal, 12/6/1962.

${ }^{311}$ A íntegra da lei está reproduzida em: GUEIROS, Nehemias, op. cit., p. 341-349.
} 
projeto elaborado, em 1960, pelas entidades paulistas, com duas emendas aprovadas pela $2^{\mathrm{a}}$ Conferência Nacional da OAB. ${ }^{312}$ Uma comissão, que contava com a participação da conselheira federal Maria Rita Soares de Andrade, ${ }^{313}$ como representante da Ordem, foi constituída no IPASE para preparar a regulamentação da lei. Quando o projeto ficou pronto, a conselheira submeteu-o ao Conselho Federal, que sugeriu algumas emendas. Entretanto, o ministério do Trabalho decidiu invalidar este projeto de regulamentação e constituir uma nova comissão, a qual deveria contar com a participação do IPASE, do Ministério do Trabalho, da OAB e do Sindicato dos Advogados. ${ }^{314}$ A medida desagradou profundamente o Conselho Federal da Ordem, sobretudo porque reconhecia a legitimidade do Sindicato dos Advogados como representante dos interesses da categoria profissional - prerrogativa reclamada pela

\footnotetext{
312 As alterações são as seguintes: 1.) O projeto das entidades paulistas, no seu artigo 10 estabelecia que a pensão seria constituída de duas partes: uma fixa e outra variável. Quanto à fixa, a alínea $a$ deste artigo estabelecia "equivalente a $30 \%$ da importância da aposentadoria que o segurado vinha recebendo ou daquela a que teria Direito, se na data da sua morte se aposentasse por invalidez". Na lei, o percentual de $30 \%$ foi aumentado para $42 \%$, segundo a alínea $a$ do artigo 10. 2.) O parágrafo $2^{\circ}$ do artigo 10 do projeto paulista estabelecia: "Ao extinguir-se o direito de um pensionista, deduzir-se-á da importância total da pensão o quinhão correspondente, até que o benefício fique reduzido a $50 \%$ da importância inicial. " Já o parágrafo $2^{\circ}$ do artigo 10 estabeleceu: "Ao extinguir-se o direito de um pensionista, deduzirse-á da importância total da pensão a cota que lhe for correspondente, na forma da alínea $b$ deste artigo, reajustando-se o cálculo da pensão." 3.) A lei, no seu artigo 21 incluiu a exigência de que a Carteira de Seguro Social dos Advogados do Brasil fosse dirigida por um advogado. 4.) A lei incluiu o artigo $25 \mathrm{com}$ a seguinte redação: "O regulamento de execução da lei proverá aos pormenores de adaptação do IPASE às novas funções e encargos." 5.) A lei, ao contrário do que determinava o projeto, permitiu que o pensionista que passasse a viver maritalmente, mas não se casasse, continuasse a receber a pensão (alínea c, artigo 11). 6.) A lei suprimiu os dispositivos do projeto que: a.) estabelecia que o valor dos benefícios seriam fixados a cada três anos e de acordo com as possibilidades financeiras da carteira (artigo 14 do projeto paulista); b.) estabelecia uma taxa de $\mathrm{Cr} \$ 100.000,00$ a ser cobrada para autorizar o funcionamento de faculdades particulares de Direito e que ajudariam no custeio dos benefícios dos advogados e seus dependentes (alínea $\mathrm{f}$ do artigo 16 do projeto paulista); c.) dispensava o beneficiário de justiça gratuita de algumas taxas criadas para custear a carteira dos advogados (parágrafo $2^{\circ}$ da alínea $\mathrm{r}$ do artigo 16); d.) exigia a contribuição previdenciária dos aposentados (parágrafo $4^{\circ}$ do artigo 17 do projeto paulista); e.) estabelecia que o fundo da carteira seria disponibilizado ao IPASE, que deveria cuidar de sua aplicação financeira, garantindo a mesma um juro mínimo de $8 \%$ ao ano (parágrafo único do artigo 21 do projeto paulista). 7.) A lei de 1962 incorporou duas emendas ao projeto paulista aprovadas pela $2^{\mathrm{a}}$ Conferência Nacional da OAB: a.) o dispositivo que fixava a parte variável do valor das aposentadorias (alínea b do artigo $7^{\circ}$ da lei de 1962); b.) a determinação de que as Caixas de Assistências dos Advogados já existentes fosse mantidas e concedessem benefícios sociais complementares aos advogados (artigo 27 da lei de 1962).

${ }^{313}$ Registre-se que Maria Rita Soares de Andrade foi a única mulher que integrou o Conselho Federal da OAB no período democrático. É provável, mesmo, que tenha sido a primeira conselheira federal da história da OAB.

${ }^{314}$ GUEIROS, Nehemias, op. cit., p. 209-214.
} 
OAB como sendo exclusivamente sua. Ao escrever, em outubro de 1963, ao presidente da seção fluminense da Ordem, o presidente Povina Cavalcanti anotou:

"Não sei até onde vão os poderes dessa Comissão [a nova comissão de regulamentação da lei], mas a verdade é que não nos foi dada a mínima satisfação, nem concordaríamos, depois dos fatos narrados, com a participação em novo Grupo de Trabalho com representante do Sindicato dos Advogados. Ou representamos nós a classe, como seu órgão supremo, ou a Comissão que resolva os seus problemas políticos sem a nossa interferência."

“(...) Eis aí, caro Presidente, o que há sobre a instalação da Carteira Social do Advogado em termos realísticos. Vejamos se com o novo Ministro do Trabalho teremos as condições para encaminhar o assunto sem influências políticas, mas, ao contrário, com a autenticidade do espírito de amparo da nossa classe. "315

Alguns dias depois do golpe de Estado de 1964, Povina Cavalcanti voltou à questão para culpar o "peleguismo dominante" outrora pela anulação do primeiro projeto de regulamentação da lei previdenciária. ${ }^{316}$ Embora carecesse de um exame mais aprofundado - o que extrapolaria os propósitos deste trabalho -, o episódio sugere uma fonte de atrito entre o governo Goulart e o Conselho Federal da OAB quanto ao papel do Sindicato dos Advogados. Bem-sucedida na campanha para aprovar o seu projeto de previdência, a elite dos advogados perturbou-se com a proximidade entre o governo e o Sindicato dos Advogados, cujos dirigentes - seria razoável supor - não pertenciam à mesma elite profissional que comandava o Conselho Federal e as seções estaduais da Ordem, além de outras entidades tradicionais de advogados. A participação do Sindicato dos Advogados na nova comissão de regulamentação da lei ameaçava o modelo previdenciário propugnado pela elite dos advogados - pois este poderia ser

\footnotetext{
315 GUEIROS, Nehemias, op. cit., p. 214.

${ }^{316}$ CF-OAB, Ata de sessão do Conselho Federal, 7/4/1964.
} 
parcialmente modificado pela regulamentação -, mas também a pretensão da $\mathrm{OAB}$ de ser o único organismo legítimo para falar em nome dos advogados.

A deposição de Goulart renovou as esperanças do Conselho Federal da OAB de implementar o seu plano previdenciário. Já no dia 28 de abril de 1964, o presidente Povina Cavalcanti informou ao Conselho Federal a retomada das negociações com o ministério do Trabalho. Ele relatou a reunião que tivera, na véspera, com o ministro da pasta, que manifestou "boa vontade (...) na solução do caso”. O bâtonnier emendou acreditar que, dali a dois meses, "teríamos uma solução definitiva para o problema" 317

\section{4.) Estágio profissional e Exame da Ordem}

O Estatuto da OAB de 1933 não impunha muitos obstáculos ao ingresso na categoria dos advogados. Entre as condições previstas estavam ter um diploma de bacharel ou de doutor em Direito e "gozar de boa reputação por sua conduta pública atestada por três advogados inscritos na Ordem. "318 Quando preparava o primeiro estatuto da Ordem, no início da década de 1930, a fração da elite dos advogados que dirigia o IAB, tendo Levi Carneiro à sua frente, debateu a pertinência de se exigir também dos ingressantes na advocacia o estágio profissional. $\mathrm{O}$ grupo dividiu-se e acabaram por vencer os que eram contrários a tal exigência. ${ }^{319}$ Já o estatuto de 1963 introduziu novos requisitos para a admissão no quadro de advogados da Ordem, destacadamente o estágio profissional, que podia ser substituído pelo Exame da Ordem. ${ }^{320}$ Ao prepararem o novo estatuto da Ordem, em meados da década de 1950, os advogados de elite concordavam entre si sobre a necessidade da implementação do estágio obrigatório. Assim, em duas décadas, o que era uma questão polêmica no seio da elite profissional tornou-se um ponto consensual. A razão de tal mudança residia na preocupação em tornar mais prática a formação do bacharel, mas, sobretudo, na inflação de diplomas, causada pela expansão dos cursos jurídicos no país.

\footnotetext{
${ }^{317}$ CF-OAB, Ata de sessão do Conselho Federal, 28/4/1964.

${ }^{318}$ Artigo 13 do Decreto ${ }^{\circ} 22.478$, de 20 de fevereiro de 1933.

319 VENÂNCIO FILHO, Alberto. Notícia histórica da OAB, 1930-1980, op. cit., p. 33 e 36.

${ }^{320}$ Artigo 48 da Lei n ${ }^{\circ} 4.215$, de 27 de abril de 1963.
} 
O tema da multiplicação das faculdades de Direito foi freqüentemente debatido ao longo da década de 1950 nas reuniões das entidades de advogados e nas convenções que agregavam a categoria profissional. A elite dos advogados responsabilizava o Estado (ou, mais precisamente, o governo federal) pelo problema e alarmou-se com suas consequiências: desprestígio social e proletarização da profissão. $\mathrm{Na} 2^{\mathrm{a}}$ Conferência Nacional da OAB, Rui de Azevedo Sodré, dirigente da seção paulista da Ordem, afirmou:

"Multiplicam-se, ainda, por todo o País, Faculdades de Direito (...) A fascinação pelo diploma de bacharel em Direito encontra meio propício para o seu desenvolvimento nas facilidades com que hoje, em todo o Brasil, se fabricam bacharéis, causando uma danosa inflação, funestamente repercutindo nos meios forenses. " 321

Durante a $1^{\text {a }}$ Conferência Nacional da OAB, Sodré desenvolvera o raciocínio, provavelmente compartilhado pelos outros advogados de elite, segundo o qual a popularização do ensino de Direito levava à depreciação social da advocacia e sua proletarização. Para ele, os advogados recém-formados se recusavam a deixar as capitais para iniciar a vida profissional no interior. Como o mercado de trabalho nas capitais encontrava-se saturado, os jovens advogados (ou, ao menos, uma boa parte deles) refugiavam-se em modestos empregos ou, se insistiam na advocacia, "não possuindo cultura nem vocação”, fracassavam. Os primeiros, deslocados no seu humilde ambiente de trabalho, graças à sua formação acadêmica, transformavam-se em “desajustados sociais", enquanto os últimos contribuíam "para aumentar a imensa vaga que quer forçar a proletarização da profissão. ,322

\footnotetext{
${ }^{321}$ Anais da $2^{a}$ Conferência Nacional da Ordem dos Advogados do Brasil, op. cit., p. 194.

${ }^{322}$ Anais da $1^{a}$ Conferência Nacional da Ordem dos Advogados do Brasil, op. cit., p. 616.
} 
A elite dos advogados interpelou o governo federal para estancar a criação de novos cursos de Direito ${ }^{323}$. A seção paulista da OAB, já em 1951, mobilizou-se para impedir a expansão do ensino jurídico no estado, cujo dinamismo econômico favorecia a instalação de faculdades de Direito. Quando malogrou o apelo para que o Ministério da Educação recuasse na sua política de autorização para a abertura de novos cursos, a OAB paulista procurou sustentação para a sua démarche no Conselho Federal da Ordem. Embora o pleito da seção paulista tenha obtido o apoio do Conselho Federal, o Ministério da Educação encontrou um defensor da sua política no interior do organismo: João Martins Rodrigues, que, além de conselheiro federal da OAB, era membro do Conselho Nacional de Educação - órgão consultado nos processos de autorização para a abertura de novos cursos de Direito. ${ }^{324}$

As entidades de advogados continuaram a pressionar o governo para que restringisse a criação de novas faculdades de Direito e fiscalizasse com maior rigor as existentes. Assim, dentre as recomendações aprovadas pela $1^{\text {a }}$ Conferência Nacional da $\mathrm{OAB}$ estavam a consulta à $\mathrm{OAB}$ antes da criação de novas faculdades de Direito, a obrigatoriedade de que ao menos $2 / 3$ dos professores das novas faculdades fossem selecionados mediante concurso de títulos e provas e a intensificação da fiscalização das faculdades já criadas. ${ }^{325}$ Em 1961, o Conselho Federal da OAB solidarizou-se com a campanha da AASP para que fosse revogado o decreto federal que autorizara o funcionamento da Faculdade de Direito de Franca. O organismo, por unanimidade, decidiu manifestar ao presidente da República “as apreensões da Ordem dos Advogados, em alguns Estados, quanto à freqüencia com que se vêm reconhecendo institutos de ensino jurídico, como a Faculdade de Direito de Franca (...). „326

\footnotetext{
${ }^{323} \mathrm{Na} 1^{\text {a }}$ Conferência Nacional da OAB, Letácio Jansen, representante do Maranhão no encontro e conselheiro federal da Ordem, pronunciou-se a favor da expansão do ensino jurídico, com o argumento de que "só redunda em benefício da cultura nacional." Anais da $1^{a}$ Conferência Nacional da Ordem dos Advogados do Brasil., op. cit., p. 516. A posição de Jansen, porém, era claramente minoritária no âmbito da elite dos advogados.

${ }^{324}$ Anais da $1^{a}$ Conferência Nacional da Ordem dos Advogados do Brasil, op. cit., p. 609-610.

${ }^{325}$ Anais da $1^{a}$ Conferência Nacional da Ordem dos Advogados do Brasil, op. cit., p. 198-199.

${ }^{326}$ CF-OAB, Ata de sessão do Conselho Federal, 18/4/1961.
} 
O Conselho Federal tentou alargar sua jurisdição para participar dos processos de autorização para a criação de novos cursos de Direito. Em meados de 1959, o presidente da OAB, Alcino Salazar, solicitou ao presidente da Comissão de Educação e Cultura da Câmara dos Deputados que incluísse na Lei de Diretrizes e Bases da Educação, em tramitação naquela casa, a representação da OAB no Conselho Nacional de Educação. ${ }^{327}$ E, em 1961, o Conselho Federal da Ordem deliberou dirigir-se ao Congresso Nacional para pedir a alteração da legislação no sentido de tornar obrigatória a consulta às seções estaduais da $\mathrm{OAB}$ nos processos de criação de novos cursos de Direito. $^{328}$

Entretanto, o antídoto à expansão do ensino jurídico considerado mais eficaz pela elite dos advogados era o estágio profissional e o Exame da Ordem. Na exposição de motivos do projeto de novo estatuto da OAB, justificou-se a adoção destes mecanismos da seguinte maneira:

“A fim de tornar exeqüível o poder de seleção da Ordem, meramente teórico até agora, assegurando a manutenção de uma verdadeira consciência profissional e elevando, ao mesmo tempo, o nível cultural da classe e a sua eficiência técnica, estabeleceu-se a exigência do estágio profissional, como requisito para a inscrição no quadro dos advogados (...) O Exame da Ordem (...) será obrigatório apenas para os candidatos à inscrição que não tenham feito o estágio profissional ou para os que não tenham comprovado satisfatoriamente o seu exercício e resultado (...)", 329

Ao examinar o projeto de novo estatuto da $\mathrm{OAB}$ na Comissão de Constituição e Justiça da Câmara dos Deputados, Milton Campos aprovou a ideia de implementação do estágio e do exame, mas censurou o formato previsto para o primeiro. Por isto, propôs uma emenda ao projeto, incorporada ao texto final do Estatuto de 1963, segundo o qual

\footnotetext{
${ }^{327}$ CF-OAB, Ata de sessão do Conselho Federal, 16/6/1959.

${ }^{328}$ CF-OAB, Ata de sessão do Conselho Federal, 18/4/1961.

${ }^{329}$ Boletim da Ordem dos Advogados do Brasil, Rio de Janeiro, volume 1, número 1, outubro 1957, p. 36.
} 
o estágio obrigatório deveria ser desenvolvido em escritórios de advocacia, órgãos públicos ou departamentos jurídicos de empresas ou, ainda, poderia ser realizado sob a orientação da $\mathrm{OAB}$ ou das faculdades de Direito. ${ }^{330}$

Como relator do tema na $1^{\text {a }}$ Conferência Nacional da OAB, Rui de Azevedo Sodré, descrente de que o governo federal retrocedesse na sua política de incentivo à expansão dos cursos jurídicos, defendeu a adoção do estágio e do exame para enfrentar a transição de "um regime de elites para o das massas". Explicava que esta medida impediria o acesso da maioria dos bacharéis em Direito ao ofício, já que esta maioria não pretenderia exercer a advocacia como sua principal atividade profissional. ${ }^{331} \mathrm{~A} 2^{\mathrm{a}}$ Conferência Nacional da OAB aprovou a instituição do estágio, mas não definiu o seu formato, recomendando o estudo da questão. ${ }^{332}$

Incapaz de persuadir o governo federal a cessar a multiplicação de bacharéis em Direito no país, a OAB recorreu ao Congresso Nacional, junto ao qual pleiteou a aprovação de seu novo estatuto, que estabelecia o estágio profissional e o Exame da Ordem, com o objetivo de reduzir a oferta de advogados no mercado de serviços. Todavia, a empreitada comportava adversários consideráveis: não apenas o governo federal - seduzido pelos ganhos políticos carreados com a expansão do ensino superior , mas, também, os próprios estabelecimentos privados de ensino. A aprovação do novo estatuto, em 1963, que estabeleceu a obrigatoriedade do estágio e do exame, representou uma vitória precária. Nenhum dos novos critérios seletivos foi efetivamente implementado e uma manobra da ditadura militar e dos estabelecimentos privados revogou, em 1972, tais mecanismos. ${ }^{333}$

O Conselho Federal também procurou combater a saturação de advogados com duas outras medidas incluídas no Estatuto de 1963: o aumento das incompatibilidades para o exercício da advocacia e a restrição à atuação dos rábulas. Entre os requisitos elencados pelo novo estatuto para a inscrição no quadro de advogados da Ordem estava

\footnotetext{
${ }^{330}$ Anais da $2^{a}$ Conferência Nacional da Ordem dos Advogados do Brasil, op. cit., p. 197-198; artigo 50 da Lei $n^{\circ} 4.215$, de 27 de abril de 1963.

${ }_{331}$ Anais da $1^{a}$ Conferência Nacional da Ordem dos Advogados do Brasil, op. cit., p. 611-612.

${ }^{332}$ Anais da $2^{a}$ Conferência Nacional da Ordem dos Advogados do Brasil, op. cit., p. 348.

${ }^{333}$ VENÂNCIO FILHO, Alberto. Notícia histórica da OAB, 1930-1980, op. cit., p. 163.
} 
a condição de não exercer qualquer atividade que reduzisse a sua independência ou possibilitasse a captação de clientela. ${ }^{334}$ Quanto aos práticos, o novo estatuto aboliu uma de suas modalidades, o solicitador ${ }^{335}$, e alterou a regra para a admissão dos provisionados. $^{336}$

Contudo, as tentativas do Conselho Federal para frear a distribuição de diplomas pelas faculdades de Direito não obtiveram qualquer êxito. Além disso, as medidas que visavam conter a expansão do número de advogados, ao que parece, tiveram efeitos bastante modestos. Na década de 1950, o número de advogados praticamente dobrou. $\mathrm{Na}$ seguinte, ele aumentou em 25\% (Tabela 2). O estágio e o exame não foram efetivamente implementados. Os rábulas, na década de 1950, representavam uma proporção pequena da categoria profissional. $\mathrm{O}$ aumento das incompatibilidades para a prática da advocacia talvez tenha sido a iniciativa mais eficaz. Porém, a diminuição do ritmo de crescimento da categoria profissional observada na década de 1960, possivelmente, deveu-se antes à saturação do mercado de trabalho do que às iniciativas da $\mathrm{OAB}$.

O combate à inflação de diplomas não constituía o único móvel - embora fosse o principal - para a instituição do estágio profissional. ${ }^{337}$ A proposta vinculava-se,

\footnotetext{
${ }^{334}$ Artigo 48 da Lei n ${ }^{\circ}$ 4.215, de 27 de abril de 1963; Boletim da Ordem dos Advogados do Brasil, Rio de Janeiro, volume 1, número 1, outubro 1957, p. 37.

${ }^{335} \mathrm{Na}$ exposição de motivos do projeto do novo estatuto da OAB explicou-se da seguinte maneira a decisão de se extinguir os solicitadores: "Com a instituição do estágio profissional e a conseqüente criação do quadro de estagiários, tornou-se inteiramente inútil a profissão de solicitador de causas, na verdade já sem expressão e sem sentido desde a promulgação do novo Código de Processo Civil. $O$ anteprojeto declara extinto o seu quadro, ressalvando o Direito dos que exerciam a profissão, com o seu limite de tempo (art. 158)." Boletim da Ordem dos Advogados do Brasil, Rio de Janeiro, volume 1, número 1, outubro 1957, p. 40. Como se nota, o documento não admitiu que a medida respondia, também, à necessidade de alargar o mercado de trabalho para os advogados formados, assaltados pelo problema da inflação dos diplomas em Direito.

336 O Estatuto de 1933, no seu artigo 14, estabelecia a exigência de que o provisionado tivesse uma autorização para advogar concedida por um juiz. Já o Estatuto de 1963, no seu artigo 52, instituiu a exigência, para a admissão no quadro de provisionados da $\mathrm{OAB}$, de prestação de uma prova perante a seção da Ordem onde se pretendia exercer as atividades profissionais.

${ }^{337} \mathrm{Na}$ abertura da $2^{\mathrm{a}}$ Conferência Nacional da OAB, Rui de Azevedo Sodré, na condição de representante da comissão executiva do evento, discursou: "Surdo o Governo aos reclamos da Ordem contra a multiplicação de Faculdades de Direito em todos os recantos do País, sem condições mínimas para o seu funcionamento, resultando dessa política uma pletora de bacharéis, com um rebaixamento espantoso do nível cultural universitário, outra alternativa não restava à Ordem senão a instituição do estágio, do curso de orientação e do exame de Ordem. Contra a abertura das portas das Faculdades, a nossa
} 
igualmente, a um programa de reforma do ensino jurídico, que pretendia torná-lo mais prático e adequado às necessidades impostas pelo desenvolvimento do capitalismo no Brasil. Não à toa, as virtudes do estágio profissional como experiência prática para os futuros advogados foram sempre louvadas por seus defensores. ${ }^{338}$

Atribuição tradicional do Estado, a OAB procurará participar do planejamento do currículo dos cursos jurídicos no país. Consultado, no final de 1955, pelo Departamento Nacional de Educação e Saúde, a propósito de um projeto de lei que introduzia modificações nos cursos de Direito, o Conselho Federal da OAB encarregou o conselheiro Carlos Alberto Dunshee de Abranches de preparar um relatório sobre o assunto. Note-se que o conselheiro federal Artur Rocha alegou a incompetência legal do Conselho para debater a questão do ensino jurídico, mas foi vencido pela maioria. No seu parecer, aprovado pela maioria do Conselho Federal, Dunshee de Abranches apresentou as seguintes propostas: 1.) a diminuição do estudo teórico nos cursos de graduação em Direito; 2.) a introdução do estágio obrigatório; 3.) uma reforma sistemática do ensino jurídico; 4.) o ensino de novos ramos do Direito, como o Financeiro; 5.) a formulação, pelo Conselho Federal, de um projeto de reforma do ensino jurídico a ser encaminhado ao governo. ${ }^{339}$

No início de julho de 1957, o Conselho Federal aprovou uma proposição de Alcino Salazar para proceder, junto às seções estaduais da Ordem, a um levantamento do número de faculdades de Direito em funcionamento no país, do número de ingressantes e formados nestes estabelecimentos e também do número de inscritos em

política de futuro, deverá ser a de cerrar as da Ordem, cautelosamente, selecionando, no seu limiar, as habilitações dos candidatos. " Anais da $2^{a}$ Conferência Nacional da Ordem dos Advogados do Brasil, op. cit., p. 13.

${ }^{338}$ No seu relatório à Comissão de Constituição e Justiça da Câmara dos Deputados, Milton Campos escreveu: "O estágio e o Exame da Ordem destinam-se a assegurar maior competência técnica ao advogado, que, por essa forma, já se inscreveria em condições de relativa familiaridade com as peculiaridades da prática profissional, e, além disso, já teria a consciência da classe mediante o noviciado de integração nela. Talvez por aí se evitasse a inscrição da generalidade dos bacharéis, nem todos verdadeiros advogados, que só esporadicamente praticam atos da profissão, sem participar realmente do seu espírito e do seu destino." BASTOS, Aurélio Wander, op. cit., p. 364.

${ }^{339}$ CF-OAB, Atas de sessão do Conselho Federal, 25/10/1955 e 1/11/1955. 
cada estado. ${ }^{340}$ Não há, porém, qualquer notícia de que este levantamento tenha sido realizado.

No ano seguinte, a $1^{\text {a }}$ Conferência Nacional da OAB examinou o tema da reforma do ensino jurídico no país. O seu relator, Orlando Gomes, que era também diretor da Faculdade de Direito da Universidade da Bahia, sugeriu uma reforma visando a ênfase na "formação profissional como reação ao teorismo" e, com este objetivo, propôs a supressão de várias cadeiras, tais como Introdução à Ciência do Direito, Teoria Geral do Estado, Direito Romano, Direito Internacional Público, Filosofia do Direito e Economia Política, a serem transferidas para os cursos de pós-graduação. A conferência, nas recomendações aprovadas, incorporou esta medida. ${ }^{341}$

${ }^{340}$ CF-OAB, Ata de sessão do Conselho Federal, 3/7/1957.

${ }^{341}$ PINTO, Adriano. A OAB nos 170 anos do ensino jurídico. In: Ensino jurídico OAB: 170 anos de cursos jurídicos no Brasil. Brasília: Conselho Federal da OAB, 1997, p. 13; Anais da $1^{a}$ Conferência Nacional da Ordem dos Advogados do Brasil, op. cit., p. 229. 


\section{CAPÍTULO III: GOVERNO GOULART E O GOLPE CIVIL-MILITAR DE 1964}

\section{1.) A renúncia de Jânio Quadros}

Em meio à crise político-militar aberta pela renúncia de Jânio Quadros, o presidente da OAB, Prado Kelly, apresentou ao Conselho Federal uma moção sobre o tema na reunião de 29 de agosto de 1961. Muitos conselheiros federais pronunciaram-se sobre o assunto que, praticamente, monopolizou aquela sessão. $\mathrm{O}$ texto da moção, aprovada por aclamação, era o seguinte:

"O CONSELHO FEDERAL da ORDEM DOS ADVOGADOS DO BRASIL, em face dos gravíssimos acontecimentos que a Nação testemunha, reafirma, ainda uma vez, sua fidelidade aos verdadeiros princípios da democracia, inscritos na Constituição, contra os extremismos da esquerda ou da direita, e apela para as autoridades e para as forças armadas, na esperança de que mantenham a ordem material, indispensável à segurança dos cidadãos, e a ordem jurídica, essencial às liberdades públicas. ${ }^{1342}$

Malgrado o seu caráter genérico, o documento pregava o respeito à Constituição - o que, naquele contexto, significava a defesa da posse do vice-presidente da República. Ao condenar o "extremismo da direita", o Conselho Federal recusava a posição golpista dos setores civis e das Forças Armadas liderados pelos ministros militares e por Carlos Lacerda. Por outro lado, censurando, igualmente, o "extremismo da esquerda", referia-se, ao que tudo indica, à disposição de setores de esquerda - a começar pelo governador gaúcho Leonel Brizola - de recorrer às armas, caso fosse necessário, para fazer valer o caminho legal. A moção invocava a estabilidade social e a ordem jurídica como os valores a serem preservados naquela conjuntura conturbada. Ao pregar uma saída equilibrada para a crise e não propugnar explicitamente a posse de Goulart com plenos poderes presidenciais, o Conselho Federal inclinava-se para uma

\footnotetext{
${ }^{342}$ CF-OAB, Ata de sessão do Conselho Federal, 29/8/1961.
} 
solução de compromisso, que bem poderia ser o parlamentarismo - já aventado naquele momento. ${ }^{343} \mathrm{Um}$ ano mais tarde, ao despedir-se do posto de presidente da OAB, Prado Kelly fez o elogio da solução parlamentarista, por ter evitado, segundo seu entendimento, a eclosão de uma guerra civil no país. ${ }^{344}$

As seções da OAB da Bahia, Rio Grande do Sul, Pará, Pernambuco e Espírito Santo manifestaram apoio à moção de 29 de agosto. ${ }^{345}$ Veículos da grande imprensa, como o Correio da Manhã e o Jornal publicaram-na na íntegra e noticiaram o pronunciamento do Conselho Federal. ${ }^{346}$

No dia 30 de agosto, o Correio da Manhã publicou uma entrevista com Alcino Salazar, o antecessor de Prado Kelly na presidência da OAB. Salazar pronunciou-se explicitamente pela posse de Goulart, argumentando que não havia qualquer fundamento legal para o seu impedimento. O ex-presidente da Ordem dos Advogados afirmou que o impeachment previsto pela Constituição de 1946 não era "medida de natureza política, como sucede em relação às moções de confiança, no regime parlamentar", mas "medida de ordem estritamente legal". Acrescentou ainda que a medida pressupunha o exercício do cargo de presidente da República. No entanto, Alcino Salazar lembrou que pesavam sobre Goulart "pesadas acusações”, que, se provadas, poderiam levar ao seu afastamento da presidência. ${ }^{347}$ A ressalva soava como uma ameaça a temidas ações esquerdistas de Goulart. Alcino Salazar já não fazia parte do Conselho Federal da $\mathrm{OAB}$, mas sua manifestação expressava a opinião dos setores conservadores que recusavam o veto militar ao vice-presidente da República. Tais setores, que incluíam, além da OAB, uma parte significativa da UDN e do PSD, mostraram-se partidários da legalidade e ciosos em impedir uma convulsão política no país. Entre o cumprimento estrito do texto da Constituição (a posse de Goulart, com plenos poderes) e uma concessão ao golpismo que evitasse o confronto militar, ficaram

\footnotetext{
343 SKIDMORE, Thomas. Brasil: de Getúlio a Castelo. Rio de Janeiro: Paz e Terra, 1982, p. $252-259$. BENEVIDES, Maria Victoria de Mesquita, op. cit., p. 118.

${ }^{344}$ CF-OAB, Ata de sessão do Conselho Federal, 11/8/1962.

${ }^{345}$ CF-OAB, Ata de sessão do Conselho Federal, 5/9/1961.

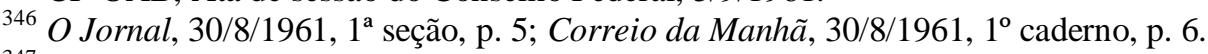

${ }^{347}$ CF-OAB, Ata de sessão do Conselho Federal, 7/8/1962.
} 
com a segunda opção. Além do mais, a alternativa parlamentarista, ao enfraquecer o poder presidencial, aliviava parte do temor quanto ao radicalismo de Goulart.

\section{2.) A tomada de posição contra Goulart}

Na sessão de 24 de julho de 1962, o conselheiro Wilson Regalado Costa pronunciou-se sobre a infiltração comunista de que o Brasil seria vítima e solicitou que o Conselho Federal constituísse uma comissão para apurar o fato. O conselheiro federal Aragão Bozano discordou da proposta, argumentando que tal medida não estava entre as atribuições do órgão. No entanto, o conselheiro Gaston Luís do Rego, em socorro à proposição de Wilson Costa, procurou adequá-la ao estatuto da $\mathrm{OAB}$. O risco à ordem jurídica representado pela infiltração comunista justificava, no entender de Gaston Rego, uma tomada de posição do Conselho Federal. O conselheiro mostrou-se especialmente preocupado com as mobilizações grevistas e denunciou a coação exercida pelos líderes paredistas, "conhecidíssimos agitadores", contra o Congresso Nacional. Os parlamentares, temerosos de atos que trouxessem a desordem ao país, encontravamse, segundo o conselheiro federal, como que chantageados pelos grevistas. Exortou o Conselho Federal a agir, em nome de sua própria sobrevivência, pois "no regime soviético, para onde querem nos conduzir”, afirmou Gaston Rego, a Ordem dos Advogados seria extinta, "de vez que o patrocínio das causas incumbe aos agentes do Estado." Ao concluir sua intervenção, o conselheiro propôs que o organismo manifestasse às autoridades públicas a sua preocupação frente à infiltração comunista e às "facilidades com que se movimentam em sua ação subversiva os agentes do marxismo colocados até em posição de comando e em pontos-chaves na administração pública. "348

Na sessão seguinte do Conselho Federal, Wilson Costa apresentou uma nova indicação sobre o tema da infiltração comunista no país. ${ }^{349}$ Embora a ata não seja clara a este respeito, é provável que ele tenha apenas modificado sua primeira proposição para conformá-la ao Estatuto da OAB. Ao se pronunciar, na condição de relator da matéria,

${ }^{348}$ CF-OAB, Ata de sessão do Conselho Federal, 24/7/1962.
${ }^{349}$ CF-OAB, Ata de sessão do Conselho Federal, 31/7/1962. 
sobre a indicação, o conselheiro Temístocles Cavalcanti endossou a posição de Wilson da Costa, quando afirmou enxergar a "deterioração do processo democrático e constitucional" e uma conjuntura de preparação para a subversão da ordem vigente. ${ }^{350}$

Em sessão extraordinária, convocada para debater o tema, Temístocles Cavalcanti apresentou uma moção aprovada unanimemente pelo Conselho Federal. Uma longa justificativa para a tomada de posição do Conselho Federal iniciava o documento que, em síntese, afirmava que o órgão agia em defesa da ordem jurídica e do exercício da advocacia, colocados em risco pelo "clima de agitação e pronunciamentos existentes no país." A moção também denunciava a deterioração do regime democrático, rejeitava soluções extremistas à esquerda e à direita (o que pode ser interpretado como a quebra da ordem constitucional) e expressava sua crença na democracia representativa. O manifesto do Conselho Federal foi divulgado para todos os membros do Congresso Nacional e todas as seções estaduais da $\mathrm{OAB}$, assim como para jornais, rádios e televisões. ${ }^{351}$ Com efeito, no dia seguinte à aprovação do documento, o Diário de Notícias e o Correio da Manhã publicaram-no na íntegra. ${ }^{352} \mathrm{O}$ presidente da seção capixaba da Ordem dos Advogados congratulou-se com o Conselho Federal pela aprovação da moção. ${ }^{353}$

As intervenções dos conselheiros federais Wilson da Costa, Gaston Rego e Temístocles Cavalcanti e, principalmente, a aprovação da moção de 9 de agosto de 1962, marcaram a adesão do Conselho Federal da OAB à campanha anticomunista sustentada durante todo o governo Goulart pelos setores sociais que, unidos numa coalizão política, promoveriam, em abril de 1964, o golpe de Estado. ${ }^{354}$ Tópicos

\footnotetext{
${ }^{350}$ CF-OAB, Ata de sessão do Conselho Federal, 7/8/1962.

${ }^{351}$ CF-OAB, Ata de sessão do Conselho Federal, 9/8/1962.

${ }^{352}$ Diário de Notícias, 10/8/1962, $1^{\text {a }}$ seção, p. 1 e 3; Correio da Manhã, 10/8/1962, $1^{\text {o }}$ caderno, p. 12.

${ }^{353}$ CF-OAB, Ata de sessão do Conselho Federal, 14/8/1962.

${ }^{354}$ Segundo Rodrigo Motta: "Um dos desdobramentos mais relevantes da conjuntura [posse de Goulart], ameaçadora do ponto de vista conservador, foi a proliferação de organizações anticomunistas. Amedrontados pela impressão de que os inimigos estavam se fortalecendo, os grupos comprometidos com o anticomunismo começaram a se organizar. Nos anos imediatamente anteriores ao golpe de 1964, uma miríade de entidades anticomunistas estruturou-se (...)." Mais, a frente, ele acrescenta: " $A$ campanha contra o comunismo adquiriu ritmo intenso e ininterrupto a partir da ascensão de Goulart, marcada por ações como protestos, comícios e passeatas. Concomitantemente, intensificaram-se as atividades de divulgação. A publicação de material anticomunista aumentou consideravelmente, na
} 
centrais da campanha anticomunista, como a oposição entre comunismo e democracia, a exortação à defesa da "civilização ocidental" e o progressivo controle do aparato estatal e de organismos civis pelos comunistas fizeram-se presentes nos documentos do Conselho Federal e nos pronunciamento de seus integrantes.

No dia 11 de agosto de 1962, realizou-se a cerimônia de posse de Povina Cavalcanti na presidência da $\mathrm{OAB}$. Ao contrário do que ocorrera nos anos anteriores, os discursos da cerimônia foram dominados pela conjuntura política e não pelas questões corporativas, as quais não foram mencionadas, à exceção do trecho final do discurso de Povina Cavalcanti, em que tratava da proletarização da categoria dos advogados, embora a relacionasse com um tema de conjuntura: a inflação. ${ }^{355}$

No seu discurso de despedida, Prado Kelly fez uma profissão de fé liberal. Seu pronunciamento reproduziu temas caros ao liberalismo, como o caráter inato da liberdade para o homem, a legitimidade da existência de diversas correntes de opinião na sociedade e a alternância pacífica no poder entre tais correntes. Aproximando o comunismo do nazifascismo, afirmou que, desde o início do século, ambas as ideologias representavam uma ameaça ao "Estado de Direito", ao “Ocidente" e à "democracia”. Para Prado Kelly, o comunismo e o nazifascismo conduziam ao mesmo caminho: ao “Estado-Nação", ao "Estado-Totalitário", ao "Minotauro", ao "Leviatã ". E completava: "A toda a evidência, o grande fato de nossos dias é a hipertrofia do Estado, ante a superstição de que deva transmutar-se em força concentradora, em órgão de distribuição de riqueza, em regulador da existência dos homens. "356 Não há dúvida de que a pregação do bâtonnier que se despedia do posto tinha alvo certo: o comunismo, cujo espectro ele reconhecia assombrando o Brasil:

“(...) pesa-nos ver deslocado para o Brasil, sedento de paz, o conflito ideológico latente em áreas subdesenvolvidas, sem a maturidade que alcançamos

\footnotetext{
forma de folhetos, livros, panfletos, cartazes etc." MOTTA, Rodrigo Patto Sá. Em guarda contra o perigo vermelho: anticomunismo no Brasil (1917-1964). São Paulo: Perspectiva/FAPESP, 2002, p. 237, 248.

${ }^{355}$ CF-OAB, Ata de sessão do Conselho Federal, 11/8/1962.

${ }^{356}$ CF-OAB, Ata de sessão do Conselho Federal, 11/8/1962.
} 
no plano histórico. Sentimos que há ameaças à ordem jurídica e assistimos à aliança de dois déspotas: a inflação desenfreada e a intolerância política. $O$ empobrecimento gradual da grande e da pequena burguesia começou a competir com as provações, que a alta dos salários já não alivia, de operários e de camponeses. (...) 'A inflação é a nossa melhor aliada'. Agradecemos a Lenine a lição e a advertência. "357

Ademais, Prado Kelly criticou o governo por propor a volta do presidencialismo, ao invés de se dedicar a debelar a crise econômico-financeira. O debate em torno do sistema de governo, asseverava o bacharel udenista, estorvava as atividades administrativas do Executivo federal. Sua crítica não se dirigia à restauração do presidencialismo em si, mas ao mecanismo de que se pretendia lançar mão para este fim: o plebiscito. Numa posição de defesa do sistema representativo, Prado Kelly argumentou que as eleições parlamentares eram a melhor forma de expressão da vontade popular a respeito do sistema de governo:

"Basta que o povo eleja em outubro deputados e senadores que lhes traduzam as preferências por um ou por outro regime. (...) Os novos mandatários virão investidos (...) do poder constituinte derivado e poderão, de uma assentada, se lograrem o 'quorum' exigido, restaurar o presidencialismo. „358

Já o discurso de Povina Cavalcanti assumiu um tom evidentemente alarmista quanto ao cenário político. O novo presidente da $\mathrm{OAB}$ afirmou temer o risco de um “colapso institucional" e via os horizontes "carregados de maus presságios". Ao assumir a presidência da Ordem, Povina Cavalcanti recuperou a atitude politizada assumida pela entidade no fim do Estado Novo:

${ }^{357}$ CF-OAB, Ata de sessão do Conselho Federal, 11/8/1962.
${ }^{358}$ CF-OAB, Ata de sessão do Conselho Federal, 11/8/1962. 
"Reconheço que os nossos horizontes não estão limitados à singela defesa de imediatos interesses profissionais, na modesta área das nossas necessidades, por assim dizer, domésticas. Creio na maior amplitude da nossa ação, entre as coordenadas do nosso patriotismo e as influências sociais do nosso meio. Não é apenas a liberdade individual que convoca o advogado à ação, que impõe a sua presença e a sua vigilância. Também as liberdades públicas no que concernem à estabilidade institucional, à defesa e à segurança do regime, necessitam da sua ajuda e cooperação. "359

Reproduzindo um argumento usado pelo Conselho Federal no biênio 1944-1945, Povina Cavalcanti afirmou que a força do órgão para defender a ordem jurídica derivava de sua autoridade moral e sua arma era a palavra: "Se a fé derruba montanhas, a palavra constrói impérios e derruba usurpadores. "360

Ainda que não mencionasse diretamente o nome do presidente da República, fica claro no discurso de Cavalcanti que era ele - e também as classes populares - quem ameaçava a estabilidade do regime:

"Quando a autoridade pública exprimir sentimentos e pregões democráticos distorsivos, atribuindo-os a coletividades desgarradas do espírito unitário da Pátria, a ação dos advogados é efetivamente criadora da liberdade. (...) Não nos arreceiemos de contrariar a própria opinião pública, se verificarmos que ela está envenenada pela paixão e pela ira. Há contrafações democráticas em muitas atitudes populares teleguiadas. "361

Povina Cavalcanti mencionou o julgamento de Cristo para atacar o apoio popular a Goulart. Usando termos como "multidão histérica" e "turbas iradas", ele lembrou do povo que se negou a absolver Cristo: “A turba pode venerar César, mas

\footnotetext{
${ }^{359}$ CF-OAB, Ata de sessão do Conselho Federal, 11/8/1962.

${ }^{360}$ CF-OAB, Ata de sessão do Conselho Federal, 11/8/1962.

${ }^{361}$ CF-OAB, Ata de sessão do Conselho Federal, 11/8/1962.
} 
César passa; é o tufão, é ruína, é espoliação, é miséria. Transitório o seu reinado, não tem aurora, mas é certo, infalível, fatal o seu ocaso. "362 A nenhum conselheiro federal podia escapar que o novo bâtonnier mencionava o imperador romano para se referir a Goulart.

O novo presidente da Ordem dos Advogados revelou, na cerimônia de sua investidura, uma atitude sensivelmente mais radical se comparada à de seu predecessor. Ainda que crítico a Goulart, Prado Kelly não o acusava de representar um risco à institucionalidade liberal. De sua parte, o novo presidente da Ordem dos Advogados denunciou o governo como a principal ameaça à ordem vigente. No dia 18 de setembro de 1962, Povina Cavalcanti afirmou que o país experimentava o agravamento da crise política. O Conselho Federal aprovou, então, o pedido de seu presidente para que pudesse convocar uma sessão extraordinária caso os acontecimentos políticos degenerassem em risco à ordem jurídica. ${ }^{363}$ A tese de que o país encontrava-se à beira de uma ruptura da legalidade, cara a Povina Cavalcanti, já havia sido enunciada por Temístocles Cavalcanti e referendada pelo Conselho Federal na moção de agosto de 1962. Adotando esta postura alarmista, muito antes dos episódios (como a Revolta dos Sargentos, a campanha das Reformas de Base e o comício da Central do Brasil) que causaram o agravamento das tensões sociais no país, o órgão contribuiu para a disseminação do clima de temor que antecedeu e legitimou a deposição de Goulart.

\section{3.) Reforma agrária}

O Conselho Federal da OAB, já antagonizado com Goulart por motivos políticos, também teve, a partir de 1963, motivos corporativos para aprofundar sua oposição ao governo. Como mencionado anteriormente, o órgão exasperou-se com os rumos dados pelo governo à regulamentação da previdência dos advogados e, igualmente, com o veto presidencial a um artigo do novo estatuto da OAB. Em janeiro de 1963, Povina Cavalcanti concedeu uma entrevista ao jornal $O$ Globo na qual atacou a condução do governo quanto à questão da previdência:

\footnotetext{
${ }^{362}$ CF-OAB, Ata de sessão do Conselho Federal, 11/8/1962.

${ }^{363}$ CF-OAB, Ata de sessão do Conselho Federal, 18/9/1962.
} 
"A hora é de distorções. O que deve constituir um objetivo inconfundivel de amparo converte-se num argumento demagógico. Há um vazio em tudo, a despeito do palavrório. Fala-se muito; age-se pouco ou nada. A verdadeira situação do profissional liberal é trágica. Processa-se a proletarização do advogado, sem que a sua condição de proletário tenha a proteção das leis que os proletários autênticos usufruem. No meio dessa confusão, os órgãos de cúpula, como é a Ordem dos Advogados do Brasil, não podem fazer nada. Mas não podem, porque não se lhes dá apreço. É mais fácil atender a uma reivindicação operária (a massa... a massa) do que a uma postulação de elite. "364

O presidente da Ordem dos Advogados expunha, assim, a sensação de duplo desprestígio experimentada pela elite dos advogados: o que atingia a categoria profissional, ameaçada de desclassificação social, e o que se abatia sobre a OAB, diminuída no seu papel de interlocutora privilegiada do Estado. Evidentemente que a ameaça de proletarização que pesava sobre os advogados não era imputada ao governo, embora Povina Cavalcanti o acusasse de omissão frente à questão. Por outro lado, Cavalcanti queixava-se amargamente do afastamento do governo em relação à $\mathrm{OAB}$ queixa que repetiria, meses depois, na já mencionada carta que enviou ao presidente da seção fluminense da Ordem dos Advogados. O bâtonnier percebia a redução da capacidade de barganha da $\mathrm{OAB}$ junto ao governo quando este reconhecia outros interlocutores na categoria profissional, como o Sindicato dos Advogados, convocado, ao lado da Ordem dos Advogados, para participar da regulamentação da lei previdenciária dos advogados.

Em abril de 1963, ao fazer a saudação aos conselheiros federais pela abertura dos trabalhos do Conselho Federal naquele ano, Oto Gil evidenciou que o órgão continuava em vigília em relação à conjuntura nacional. Responsabilizou o

\footnotetext{
${ }^{364}$ CF-OAB, Ata de sessão do Conselho Federal, 7/4/1964.
} 
“caudilhismo indígena” e os "demagogos" pelas ameaças que pairavam sobre a ordem jurídica do país. E adiantou a oposição do Conselho Federal às Reformas de Base:

"Haverá, porém, onde redobrar a nossa vigilância e pugnacidade: é quanto aos propósitos, ainda encabuçados, da Reforma Constitucional, que se pretende obter do Congresso Nacional sob a mais odienta coação: a de que o Congresso Nacional falharia à Nação se não votasse, imediatamente, a toque de tambor, a reforma que o Executivo lhe vai pedir, em nome do 'salus poluli', ou seja, da 'salvação nacional'!, 365

Oto Gil reafirmou a disposição do Conselho Federal de zelar pela manutenção da ordem jurídica, lembrando o especial compromisso dos advogados com esta missão. O conselheiro federal sugeriu que os bacharéis, naquele momento, constituíam o principal obstáculo às iniciativas governamentais, interpretadas como atentatórias à ordem jurídica. ${ }^{366}$

Naquele mês, o deputado Bocaiúva Cunha, líder do PTB na Câmara dos Deputados, apresentou um projeto que pretendia viabilizar a reforma agrária ao, alterando a Constituição, permitir o pagamento de indenização pelas desapropriações de terra com títulos da dívida pública. ${ }^{367}$ Logo, o conselheiro Renato Ribeiro pediu que o Conselho Federal examinasse o projeto de lei. Nomeado relator da indicação de Renato Ribeiro, Carlos Medeiros Silva apresentou seu parecer no dia 30 de abril. Nele, defendia o projeto de Bocaiúva Cunha, mas fazia uma importante ressalva. Carlos Medeiros argumentou que a proposta não protegia suficientemente as indenizações da inflação. A desvalorização da moeda, argumentava o conselheiro federal, poderia transformar a desapropriação em "disfarçado ou mero confisco". Em conclusão, pronunciou-se sobre a necessidade de que, durante sua tramitação no Congresso Nacional, o projeto fosse

\footnotetext{
${ }^{365}$ CF-OAB, Ata de sessão do Conselho Federal, 2/4/1963.

${ }^{366}$ CF-OAB, Ata de sessão do Conselho Federal, 2/4/1963.

${ }^{367}$ TOLEDO, Caio Navarro de. O governo Goulart e o golpe de 64. São Paulo: Brasiliense, 2004, p. 5556. BENEVIDES, Maria Victoria de Mesquita, op. cit., p. 189-194. HIPPOLITO, Lucia. De raposas e reformistas: o PSD e a experiência democrática brasileira, 1945-64. Rio de Janeiro: Paz e Terra, 1985, p. 224-232.
} 
alterado no sentido de não limitar a correção monetária dos títulos da dívida pública com que as desapropriações seriam pagas (o projeto Bocaiúva Cunha limitava a correção monetária a 10\% ao ano). Carlos Medeiros argumentou ainda contra o risco de que as desapropriações se transformassem em confisco: “E as Emendas Constitucionais não se fazem para pôr em risco a ordem social, mas a fim de assegurar, ao povo, a paz e a segurança." 368 É interessante notar que, ao apoiar um projeto que pretendia viabilizar a reforma agrária, Carlos Medeiros justificou seu apoio com o argumento da estabilidade social, sem fazer qualquer referência a direitos sociais.

No dia 14 de maio, o conselheiro federal Carlos Bernardino de Aragão Bozano, apoiado por 15 delegações, apresentou ao Conselho Federal um parecer substitutivo ao de Carlos Medeiros. O novo parecer refutava firmemente o projeto Bocaiúva. ${ }^{369} \mathrm{O}$ teor do substitutivo era o seguinte:

"A Ordem dos Advogados do Brasil manifesta sua contrariedade à pretendida reforma constitucional, eis que, além de perigosa como precedente, atenta contra o direito de propriedade e resulta totalmente desnecessária ao fim declarado, o de proporcionar aos trabalhadores rurais o acesso às terras. Dentro na Constituição da República, como na legislação ordinária em vigor, há elementos suficientes para a mudança da estrutura agrária do país, atendendo ao Homem e às necessidades da produção, sem que sejam golpeados os direitos fundamentais dos cidadãos e com grave risco para a ordem jurídica. ${ }^{1370}$

O novo parecer foi aprovado por ampla maioria - apenas as delegações do Rio de Janeiro e do Espírito Santo votaram contra. O resultado demonstrou que já se consolidara no Conselho Federal da $\mathrm{OAB}$ a posição de recusa ao projeto Bocaiúva que também se tornaria francamente majoritária tanto no PSD quanto na UDN. Depois da aprovação do substitutivo, o conselheiro Renato Ribeiro pediu que seu teor fosse

\footnotetext{
${ }^{368}$ CF-OAB, Ata de sessão do Conselho Federal, 30/4/1963.

${ }^{369}$ CF-OAB, Ata de sessão do Conselho Federal, 14/5/1963.

${ }^{370}$ CF-OAB, Ata de sessão do Conselho Federal, 14/5/1963.
} 
imediatamente comunicado ao Congresso Nacional, onde ainda tramitava o projeto. ${ }^{371}$ A decisão do Conselho Federal da $\mathrm{OAB}$ foi noticiada no dia seguinte por órgãos da grande imprensa, como O Jornal e o Correio da Manhã. ${ }^{372}$

$\mathrm{O}$ pronunciamento da $\mathrm{OAB}$ ancorava-se em dois valores: a institucionalidade vigente e o direito de propriedade. A oposição dos setores conservadores, entre os quais a $\mathrm{OAB}$ se incluía, à reforma constitucional animava-se não apenas por interesses econômicos contrariados pelo projeto, mas comportava também um importante componente político. Temia-se que a aprovação da emenda constitucional fortalecesse o programa de reformas de Goulart e, com maior ou menor sinceridade, que a reforma agrária fosse o primeiro passo rumo à socialização dos meios de produção no país. Receava-se, igualmente, que a reforma constitucional abalasse a base social mantida pelo PSD e pela UDN no campo e que os trabalhadores rurais, livres da dominação do latifúndio, se tornassem eleitores de João Goulart e da esquerda. ${ }^{373}$

\section{4.) O episódio Hélio Fernandes}

Em meados de 1963, o Conselho Federal da OAB acolheu uma ação dos bacharéis udenistas contra o governo Goulart que reeditava táticas de sua luta contra o Estado Novo. Ao defender um notório oposicionista que tivera seu direito de defesa violado, o Conselho Federal procurou atingir Goulart e seu ministro da Guerra. A ação oposicionista foi desencadeada pela prisão de Hélio Fernandes, proprietário da Tribuna da Imprensa, jornal de inspiração lacerdista que promovia virulenta oposição a Goulart. Em julho de 1963, Hélio Fernandes publicou, no seu periódico, uma carta endereçada pelo ministro da Guerra, Jair Ribeiro Dantas, a generais de sua confiança, na qual atacava Carlos Lacerda, então governador da Guanabara. Enquadrado na Lei de Segurança Nacional pelo ato, o jornalista foi preso pelo Exército. ${ }^{374}$ Hélio Fernandes constituiu um grupo de notáveis bacharéis udenistas como seus advogados: Prado Kelly,

\footnotetext{
${ }^{371}$ CF-OAB, Ata de sessão do Conselho Federal, 14/5/1963.

372 O Jornal, 15/5/1963, $1^{\circ}$ caderno, p. 6; Correio da Manhã, 15/5/1963, $1^{\circ}$ caderno, p. 3.

373 TOLEDO, Caio Navarro de. O governo Goulart e o golpe de 64, op. cit., p. 55-56. BENEVIDES, Maria Victoria de Mesquita, op. cit., p. 189-194. HIPPOLITO, Lucia, op. cit., p. 224-232.

${ }^{374}$ FERREIRA, Marieta de Morais. FERNANDES, Hélio. In: ABREU, Alzira Alves de et alli. (coord.), op. cit.
} 
Adauto Lúcio Cardoso, Sobral Pinto, Prudente de Morais Neto e João Franzen de Lima. Depois de uma primeira visita ao preso, seus advogados foram impedidos de revê-lo. A incomunicabilidade de Fernandes durou alguns dias, mesmo depois que o ministro do STF Ribeiro da Costa determinou o fim da medida. Em reação, além de divulgarem uma nota de protesto na imprensa, os defensores de Hélio Fernandes recorreram à OAB. O presidente da Ordem, Povina Cavalcanti, e o presidente da seção da Guanabara, Jorge Lafayette Pinto Guimarães, mobilizaram-se pela causa dos bacharéis udenistas. No dia 30 de julho, Prado Kelly compareceu à sessão do Conselho Federal da Ordem para agradecer a Povina Cavalcanti e Pinto Guimarães pelo empenho em favor de Fernandes no episódio. O Conselho Federal debateu os acontecimentos e, por ampla maioria, aprovou uma indicação com os seguintes pontos: 1.) manifestar solidariedade ao presidente da $\mathrm{OAB}$, ao presidente da seção da Guanabara, a Prado Kelly e aos "ilustres advogados, pela defesa destemida que fizeram do direito de os advogados se comunicarem com seus clientes"; 2.) dirigir protesto ao presidente da República pela violação desse direito; 3.) assinalar um voto de regozijo pela decisão do STF, que assegurou tal direito. ${ }^{375}$

Na mesma sessão, foi aprovada a proposta do conselheiro Aragão Bozano para a instauração de uma sindicância pela seção da Guanabara com a finalidade de apurar a participação de advogados (que não são nomeados), que, segundo a imprensa, teriam aconselhado as autoridades militares a não permitirem a entrevista de Fernandes com seus constituintes. ${ }^{376}$ Os conselheiros aprovaram, igualmente, a proposta de Alci Amorim da Cruz para que fossem processados criminalmente os responsáveis pela violação da prerrogativa dos advogados de visitarem o seu cliente. O conselheiro Agenor Teixeira de Magalhães, apoiado por Oto Gil, manifestou-se por uma ação criminal contra o ministro da Guerra, considerado responsável pela violação. ${ }^{377}$ Nos

\footnotetext{
375 CF-OAB, Ata de sessão do Conselho Federal, 30/7/1963.

${ }^{376}$ CF-OAB, Ata de sessão do Conselho Federal, 30/7/1963.

${ }^{377}$ CF-OAB, Ata de sessão do Conselho Federal, 30/7/1963.
} 
dias seguintes, o Conselho Federal da OAB recebeu a solidariedade de algumas de suas seções estaduais, além da AASP, pela sua atitude no episódio Hélio Fernandes. ${ }^{378}$

Povina Cavalcanti encomendou um parecer ao jurista Hélio Tornaghi sobre a possibilidade de processar criminalmente os responsáveis pelo impedimento de Hélio Fernandes receber a visita de seus advogados. Na sessão de 13 de agosto, Tornaghi apresentou suas conclusões ao Conselho Federal. Entendia não ser possível processar criminalmente os responsáveis pela violação, mas sugeriu que a Ordem se dirigisse ao ministro da Guerra para solicitar a investigação "da responsabilidade disciplinar” dos militares envolvidos. ${ }^{379}$

\section{5.) A Revolta dos Sargentos}

No dia 17 de setembro de 1963, Wilson Regalado da Costa propôs que o Conselho Federal da OAB manifestasse ao STF sua solidariedade "no momento em que um de seus ilustres membros foi vítima de arbitrariedade por parte de militares insurretos”. Neste mesmo dia, Renato Ribeiro pediu ao Conselho a aprovação de um voto de apoio ao Exército "pela atitude assumida, recentemente, em prol da ordem e da tranqüilidade da Nação." 380 Os dois pronunciamentos referiam-se, muito provavelmente, à Revolta dos Sargentos, eclodida há poucos dias. Os rebeldes, em protesto contra a decisão do STF que confirmou a inegibilidade dos graduados (sargentos, suboficiais e cabos) das Forças Armadas, prenderam, entre outras autoridades, Vitor Nunes Leal, ministro daquela corte. O movimento acabou debelado pelo Exército. ${ }^{381}$ Ainda na esteira destes acontecimentos, o Conselho Federal, por unanimidade, aprovou a proposta de Wilson Regalado da Costa e decidiu dirigir-se ao STF para manifestar

\footnotetext{
${ }^{378}$ CF-OAB, Atas de sessão do Conselho Federal, 6/8/1963 e 20/8/1963.

${ }^{379}$ CF-OAB, Ata de sessão do Conselho Federal, 13/8/1963.

${ }^{380}$ CF-OAB, Ata de sessão do Conselho Federal, 17/9/1963.

381 TOLEDO, Caio Navarro de. 1964: o golpe contra as reformas e a democracia. Revista Brasileira de História, São Paulo, volume 24, número 47, 2004, p. 26; LAMARÃO, Sergio. Revolta dos sargentos. In: ABREU, Alzira Alves de et alli. (coord.), op. cit.
} 
“a sua imperecivel confiança na Justiça, que o Egrégio Tribunal simboliza e encarna, na sua mais alta expressão, e repele, com veemência, as expressões injuriosas dirigidas aos Juízes do Supremo Tribunal, constituindo, esta manifestação, solene desagravo ao próprio Tribunal, cuja autoridade e cujas prerrogativas constitucionais, nos cumpre preservar, força de disposição expressa de nosso Estatuto. ${ }^{1382}$

O Conselho Federal, como fizera na condenação do projeto de reforma agrária, ignorou a questão substantiva contida no levante dos sargentos: a ampliação da democracia política. Recusando-se a debater as reivindicações populares, o órgão procurava contê-las com a alegação de que seu teor e suas formas de expressão feriam a ordem jurídica.

\section{6.) Nas vésperas do golpe}

Em 20 de março de 1964, em meio à radicalização política que marcou o fím do governo Goulart, o Conselho Federal realizou uma sessão extraordinária para debater os últimos acontecimentos. O órgão, nesta ocasião, aprovou uma moção centrada na defesa da legalidade:

"O CONSELHO FEDERAL da ORDEM DOS ADVOGADOS DO BRASIL (...) RESOLVE,(...) diante da notória e grave crise por que passa, no momento, a ordem jurídica no país: $1^{\circ}$ ) Reconhecer e proclamar a necessidade de preservar e garantir o livre funcionamento dos poderes constituídos da República, na órbita federal e em cada unidade da Federação, o resguardo do princípio da autoridade e de todos os direitos, com o imediato objetivo de restaurar a tranqüilidade pública, perturbada por movimentos de agitação, ameaças e atos contrários à Constituição e às leis. $2^{\circ}$ ) Apelar para os poderes constituídos, no sentido de, serenamente, cumprirem e fazerem cumprir a Constituição e as leis. $3^{\circ}$ ) $O$

\footnotetext{
${ }^{382}$ CF-OAB, Ata de sessão do Conselho Federal, 1/10/1963.
} 
Conselho Federal da Ordem dos Advogados do Brasil não é insensível às reivindicações justas e legítimas, mas sempre que afastem meios de propaganda de soluções extra-constitucionais. O regime democrático estabelecido pela Constituição Federal permite a realização de todas as aspirações, dentro da lei e do respeito à ordem jurídica. , 383

O documento foi encaminhado à presidência da República, ao Congresso Nacional, às Assembléias Legislativas dos estados, ao STF, ao Tribunal Federal de Recursos e às seções estaduais da $\mathrm{OAB}{ }^{384}$ Nos dias seguintes, jornais divulgaram o manifesto da OAB. Além de publicar integralmente a moção da Ordem dos Advogados, o Correio da Manhã do dia 22 de março trouxe uma entrevista com Povina Cavalcanti sobre o assunto. ${ }^{385}$

Houve, contudo, vozes discordantes na aprovação da moção. O conselheiro Paulo Belo propôs adicionar um trecho ao documento aprovado que continha tanto um apoio às Reformas de Base quanto um apelo para que a luta política não violasse a legalidade. Ele sugeriu:

"Fazer um apelo aos partidos políticos e organizações de classe, dos campos e das cidades, para conduzirem as suas reivindicações e correspondentes debates num clima de respeito às leis e às instituições, sem excessos e radicalizações. Solicitar que o Congresso Nacional, como legítimo representante do povo, no uso de sua soberania, atendendo a realidade nacional, examine com urgência que se faz necessária, as reformas indispensáveis à reestruturação da política social e econômica reclamada pela Nação, votando as leis adequadas, constitucionais ou ordinárias. "1386

\footnotetext{
${ }^{383}$ CF-OAB, Ata de sessão do Conselho Federal, 20/3/1964.

${ }^{384}$ CF-OAB, Ata de sessão do Conselho Federal, 20/3/1964.

${ }^{385}$ Correio da Manhã, 22/3/1964, $1^{\circ}$ caderno, p. 24.

${ }^{386}$ CF-OAB, Ata de sessão do Conselho Federal, 20/3/1964.
} 
Todavia, a emenda de Paulo Belo foi rejeitada pela maioria do Conselho Federal. ${ }^{387}$ O Diário de Notícias reproduziu trechos do acalorado debate que cercou a aprovação da moção de 20 de março. Segundo o periódico, o conselheiro federal Wilson do Egito Coelho destacou-se na refutação aos ataques feitos por outros membros do Conselho Federal ao presidente da República, considerando-os inconsistentes. Por outro lado, conselheiros federais alinhados à posição hegemônica no organismo desfiaram acusações ao governo federal. Gaston Luís do Rego procurou deslegitimar o apoio popular às iniciativas de Goulart: "O presidente da República (...) tem dito que governa com o povo, mas esse povo de que ele fala são entidades espúrias.” Renato Ribeiro sugeriu "haver o deliberado propósito de destruir a estrutura jurídica do país, e isso exatamente por homens incapazes de construir." E afirmou ainda que as Reformas de Base eram recusadas por todos os brasileiros. Além disto, alguns conselheiros denunciaram a inconstitucionalidade de algumas medidas governamentais, como a desapropriação de terras, a encampação de refinarias e o tabelamento de aluguéis. ${ }^{388}$

O Conselho Federal da OAB, com exceção de poucas vozes, identificava a questão social com o risco à ordem jurídica. Alguns setores da oposição a Goulart inclinaram-se, por algum momento, pelas reformas propostas pelo governo, considerando-as um antídoto contra o proselitismo comunista. Entretanto, esta nunca foi a posição majoritária no Conselho Federal. O órgão sempre refutou as reivindicações populares lançando mão da "camisa de força" representada pela Constituição de 1946. Ironicamente, a defesa da legalidade serviu como obstáculo para impedir que a experiência democrática iniciada em meados da década de 1940 se aprofundasse, com a expansão dos direitos políticos e sociais.

\section{7.) Ditadura Militar}

Na primeira sessão do Conselho Federal da OAB após o golpe civil-militar que depôs Goulart, o presidente da Ordem, Povina Cavalcanti, saudou o movimento:

\footnotetext{
${ }^{387}$ CF-OAB, Ata de sessão do Conselho Federal, 20/3/1964.

${ }^{388}$ Diário de Notícias, 21/3/1964, 1a seção, p. 2.
} 
"Dispensamo-nos de dar ênfase à certeza de que, nesta Casa, somos todos, a par de vigilantes operadores da seleção disciplinar e da defesa dos advogados, cruzados valorosos do respeito à ordem jurídica e à Constituição. Neste sentido, Srs. Conselheiros, orgulhamo-nos de estar em paz com a nossa consciência. Em sessão de 14 de maio do ano passado, sob ameaças de diferentes origens, mas sobretudo encampadas pelo Governo Federal, através de uma tolerância, que redundava em cumplicidade, este Egrégio Conselho teve o seguinte pronunciamento: (...) [cita integralmente a moção aprovada em 14 de maio de 1963 contra o projeto de reforma agrária] E ainda agora, antecipando-nos à derrocada das forças subversivas, acionadas por dispositivos governamentais, que visavam, já sem disfarces, à destruição do primado da democracia e à implantação de um regime totalitário, no qual submergiriam todos os princípios da liberdade humana, tivemos a lucidez e o patriotismo de alertar, na memorável reunião extraordinária de 20 de março p. findo, os poderes constituídos da República para a defesa da ordem jurídica e da Constituição, tão seriamente ameaçadas. Mercê de Deus, sem sairmos da órbita constitucional, podemos hoje, erradicado o mal das conjuras comuno-sindicalistas, proclamar que a sobrevivência da Nação Brasileira se processou sob a égide intocável do Estado de Direito. Que a Providência Divina inspire os homens responsáveis desta terra e lhes ilumine a consciência jurídica, pois que sem o Direito, como pregou Rui Barbosa - não há salvação. "1389

Note-se que o argumento utilizado pelo bâtonnier para justificar a deposição de Goulart era exatamente o mesmo usado pelos artífices do golpe de Estado: a de que ele teria sido executado para, evitando a subversão comunista encampada pelo governo federal, conservar a ordem jurídica. Contudo, o Conselho Federal mostrou-se transigente na defesa da legalidade. Não apenas porque fechou os olhos à evidente ruptura constitucional representada pela destituição de Goulart, mas também porque, ao

\footnotetext{
${ }^{389}$ CF-OAB, Ata de sessão do Conselho Federal, 7/4/1964.
} 
ceder seu presidente à Comissão Geral de Investigações (CGI), referendou a perseguição inquisitorial contra os inimigos do novo regime conduzida pelos responsáveis pelos Inquéritos Policiais-Militares (IPMs). ${ }^{390}$

Nesta mesma sessão, o conselheiro Gaston Luís do Rego manifestou a sua satisfação "com a vitória da revolução de $1^{\circ}$ de abril último". ${ }^{391} \mathrm{Na}$ semana seguinte, o conselheiro Eurico Raja Gabaglia mencionou "o sentimento de júbilo de que estão possuidos todos os bons brasileiros pela recente redemocratização do País. "392

O Conselho Federal recebeu satisfeito os convites feitos, logo nos primeiros meses do novo regime, para colaborar com o governo. O organismo percebia o novo padrão de relacionamento com o Executivo (a relação de colaboração com o novo regime contrastava com o relacionamento conflituoso e distanciado com o governo deposto) como uma recuperação de seu prestígio. A Ordem dos Advogados voltava a ser tratada com deferência por ministros de Estado. Assim, ainda em abril de 1964, Povina Cavalcanti foi recebido pelo ministro do Trabalho para tratar de uma questão cara à entidade: a previdência dos advogados. Ao mesmo tempo, era convocada para integrar comissões governamentais. No dia 28 de abril, o presidente da OAB informou ao Conselho Federal ter sido designado por Castelo Branco membro da comissão incumbida de verificar o estado de saúde dos nove integrantes da comissão comercial chinesa presos pelo Exército, ao lado do embaixador do Paquistão no Brasil e do presidente da Cruz Vermelha no país. Refutando a denúncia de tortura dos prisioneiros, a comissão, segundo Povina Cavalcanti, constatou que eles não tinham sofrido quaisquer maus-tratos. No seu relato, o presidente da Ordem interpretou sua nomeação como uma "consideração especial” de Castelo Branco. ${ }^{393}$ Semanas depois, Povina Cavalcanti foi designado vice-presidente da Comissão Geral de Investigações (CGI).

\footnotetext{
390 Também nos estados, segundo o depoimento de José Cavalcanti Neves (presidente do Conselho Federal no início da década de 1970), a OAB endossou a perseguição aos inimigos do novo regime, ao permitir que presidentes de suas seccionais integrassem subcomissões de investigações. Entrevista de Marly Motta com José Cavalvanti Neves, em 07/07/2003, In: MOTTA, Marly Silva da (org.). A OAB na voz de seus presidentes. Brasília: OAB, 2003, v. 7, p. 52.

${ }^{391}$ CF-OAB, Ata de sessão do Conselho Federal, 7/4/1964.

${ }^{392}$ CF-OAB, Ata de sessão do Conselho Federal, 14/4/1964.

${ }^{393}$ CF-OAB, Ata de sessão do Conselho Federal, 28/4/1964.
} 
Novamente, o Conselho Federal reconheceu a nomeação como uma deferência governamental à OAB. O conselheiro Gaston Luís do Rego, na sessão de 26 de maio, apresentou a Cavalcanti as suas congratulações pela designação. ${ }^{394}$

Neste período, o único obstáculo ao apoio da $\mathrm{OAB}$ à ditadura militar foram as violações às prerrogativas dos advogados cometidas por autoridades encarregadas da repressão política. Na mesma ocasião em que Povina Cavalcanti louvou o novo regime, o conselheiro Jorge Botelho demonstrava preocupação com a situação dos advogados presos. A intervenção do conselheiro foi omitida da ata da sessão, o que causou o seu protesto na reunião seguinte. ${ }^{395}$ Mesmo um entusiasta da nova ordem como o conselheiro Gaston Luís do Rego preocupou-se com a prisão dos advogados. Ele propôs que o Conselho Federal fizesse gestões junto ao governo para que os presidentes das seções estaduais da Ordem fossem consultados antes da prisão de quaisquer de seus membros. A votação da proposta foi protelada por quase seis meses para ser rejeitada por ampla maioria. ${ }^{396}$

Na sessão de 15 de outubro de 1964, o representante goiano no Conselho Federal Wilson Regalado da Costa levou ao conhecimento de seus pares um incidente ocorrido entre o presidente da seção da OAB de seu estado, Rômulo Gonçalvez, e o comandante do $10^{\circ}$ Batalhão de Caçadores, o tenente-coronel Danilo de Sá da Cunha e Melo. Ligado aos setores radicais do Exército, o oficial chefiava os Inquéritos PoliciaisMilitares (IPMs) instaurados pelo novo regime em Goiás. Ao investigar um inverossímil núcleo de guerrilha vinculado ao governador goiano Mauro Borges, Cunha e Mello prendera o advogado João Batista Zacariotti, subchefe do gabinete civil do governo Borges. ${ }^{397}$ Com o propósito de ver cumprido o habeas corpus concedido a Zacariotti pelo Superior Tribunal Militar (STM), Rômulo Gonçalvez telefonou ao tenente-coronel. Wilson da Costa relatou o episódio da seguinte maneira:

\footnotetext{
${ }^{394}$ CF-OAB, Ata de sessão do Conselho Federal, 26/5/1964.

395 CF-OAB, Ata de sessão do Conselho Federal, 14/4/1964.

${ }^{396}$ CF-OAB, Ata de sessão do Conselho Federal, 23/6/1964 e 1/12/1964.

${ }^{397}$ GASPARI, Elio. A ditadura envergonhada. São Paulo: Companhia das Letras, 2002, p. 187-189.
} 
“(...) o Dr. Rômulo Gonçalves (...) dirigiu-se àquela autoridade militar encarecendo providências para o imediato cumprimento do habeas corpus (...). É que o referido oficial, Danilo Cunha Melo, rispidamente, recusou-se a qualquer entendimento e, apesar de esclarecido delicadamente de que era o Presidente da Ordem dos Advogados, Seção local, que falava ao telefone, advertiu, então, com entonação de voz mais agressiva ainda, que o interlocutor ficava proibido de voltar a fazer qualquer ligação telefônica para o quartel, batendo a seguir o fone, de forma a mais violenta possivel. ${ }^{398}$

Revelador, o episódio demonstrava que a perseguição política do novo regime começava a vitimar antigos conspiradores, como Mauro Borges, que apoiara o golpe de Estado. E antagonizava homens que estavam do mesmo lado antes do golpe, como era o caso de Danilo Cunha Melo e Wilson Regalado da Costa, que, no Conselho Federal da $\mathrm{OAB}$, dera repetidas demonstrações de sua aversão ao governo Goulart. Percebe-se, igualmente, que já nascera uma fonte de atrito entre o governo e a $\mathrm{OAB}$ que contribuiu de maneira importante para que a entidade, na década de 1970, se deslocasse para a oposição à ditadura militar: as arbitrariedades de autoridades policiais e militares contra advogados e o desrespeito destas mesmas autoridades às prerrogativas profissionais dos advogados. Naquele episódio, os conselheiros federais perceberam que a atuação profissional dos advogados corria perigo, assim como a autoridade do Poder Judiciário (que tivera uma decisão sua ignorada por um oficial do Exército) e, em decorrência, a ordem jurídica que a $\mathrm{OAB}$ defendia.

Devido à gravidade da situação, o relator nomeado por Povina Cavalcanti para examinar o caso apresentou suas conclusões na mesma sessão em que Wilson da Costa relatou os acontecimentos. Antes de tudo, o parecer do conselheiro Alfio Ponzi sublinhava a autoridade dos presidentes das seções estaduais e do Conselho Federal para, com base no Estatuto da $\mathrm{OAB}$, zelar pelo cumprimento da lei, pelo respeito às decisões judiciais e pela observância das prerrogativas dos advogados. Em seguida,

\footnotetext{
${ }^{398}$ CF-OAB, Ata de sessão do Conselho Federal, 15/10/1964.
} 
Alfio Ponzi propunha: 1.) comunicar o ministro da Guerra sobre o ocorrido para avaliar "possíveis excessos de seus comandados"; 2.) solicitar que o STM tomasse as providências necessárias para que se fizesse cumprir o habeas corpus em favor de Zacariotti; 3.) dirigir-se ao ministro da Justiça "para que empenhe a sua autoridade no sentido de coibir violências contra o império da lei"; 4.) desagravar o presidente da OAB goiana, manifestando o reconhecimento do Conselho Federal pela sua atuação no episódio. A proposição do relator foi aprovada unanimemente pelo Conselho Federal. ${ }^{399}$

Em meados de 1964, o presidente da OAB decidiu que os advogados cassados pelo Ato Institucional $\mathrm{n}^{\circ} 1$ (AI-1) poderiam continuar a exercer o ofício. A medida protegia os interesses da corporação e, ao mesmo tempo, tinha potencial para desagradar ao regime. Povina Cavalcanti justificou a decisão afirmando esperar que a "Revolução não use um eufemismo de paredón para matar de fome advogados do Brasil." $\mathrm{O}$ Conselho Federal, por unanimidade, referendou a decisão. ${ }^{400}$

No final de 1964, uma proposta formulada pelo ex-presidente da OAB e membro-nato de seu Conselho Federal Miguel Seabra Fagundes dividiu o órgão. Devido a seguidas concessões de habeas corpus a políticos perseguidos pelo regime, o STF tornou-se alvo de protestos e manifestações de animosidade por parte dos setores radicais do regime. ${ }^{401}$ Neste contexto, Seabra Fagundes apresentou a seguinte indicação, subscrita por outros dez conselheiros federais:

"Tendo em vista as acusações recentes, graves e reiteradas, feitas à honorabilidade de ministros do Supremo Tribunal Federal, acusações que notoriamente não correspondem à verdade, e que se verdadeiras comprometeriam a própria dignidade nacional, formulamos indicação no sentido de que o Conselho Federal da Ordem dos Advogados do Brasil dê o seu

\footnotetext{
${ }^{399}$ CF-OAB, Ata de sessão do Conselho Federal, 15/10/1964.

${ }^{400}$ CF-OAB, Ata de sessão do Conselho Federal, 23/6/1964.

${ }^{401}$ COSTA, Emília Viotti da. O Supremo Tribunal Federal e a construção da cidadania. São Paulo: Editora UNESP, 2006, p. 163-165. MATTOS, Marco Aurélio Vannucchi Leme de, SWENSSON JÚNIOR, Walter Cruz. Contra os inimigos da ordem: a repressão política da ditadura militar (19641985). Rio de Janeiro: DP\&A, 2003, p. 22-25.
} 
testemunho à Nação de que não existe naquela corte nenhum juiz cuja honorabilidade pessoal se possa pôr em dúvida."

Em seguida, instalou-se um tumulto no Conselho em torno da indicação e, astutamente, Povina Cavalcanti encerrou a sessão antes que a proposta fosse votada. ${ }^{402}$

Não apenas o Conselho Federal da OAB como instituição apoiou a derrubada de João Goulart, mas também os seus integrantes, individualmente, solidarizaram-se com o golpe de Estado ou mesmo tomaram parte de seus preparativos. Na realidade, os bacharéis que compuseram a diretoria do Conselho Federal a partir de 1962 estavam diretamente vinculados ao complexo IPES/IBAD (Instituto de Pesquisas e Estudos Sociais/Instituto Brasileiro de Ação Democrática), para onde convergiam as articulações golpistas. Povina Cavalcanti, o presidente da Ordem dos Advogados entre 1962 e 1965, além de filiado ao complexo IPES/IBAD, era diretor da Associação dos Amigos das Nações Cativas, entidade dedicada à campanha anticomunista nos moldes da ação desenvolvida pelo IPES. Alberto Barreto de Melo, secretário-geral da OAB entre 1952 e 1965 e seu presidente entre 1965 e 1967, também era associado do complexo IPES/IBAD e dirigente da mesma Associação dos Amigos das Nações Cativas. ${ }^{403}$ Observe-se, de passagem, que, entre os dirigentes desta associação que também eram filiados ao complexo IPES/IBAD, estavam Raul Fernandes, presidente da OAB entre 1944 e 1948, e Dario de Almeida Magalhães, conselheiro federal da Ordem até $1954{ }^{404}$ Por sua vez, Temístocles Marcondes Ferreira, representante paulista no Conselho Federal da OAB por todo o período democrático, vice-presidente da Ordem entre 1962 e

\footnotetext{
${ }^{402}$ CF-OAB, Ata de sessão do Conselho Federal, 15/12/1964.

${ }^{403}$ DREIFUSS, René Armand. 1964: a conquista do Estado. Petrópolis: Vozes, 1981, p. 293. René Dreifuss descreve a Associação dos Amigos das Nações Cativas da seguinte maneira: "Merece atenção o fato de que entre as organizações de 'guerra fria', cuja campanha de propaganda coincidia com a do IPES, destacavam-se a Associação dos Amigos das Nações Cativas e o Rearmamento Moral. A Associação era uma organização 'guarda-chuva', fortemente anticomunista, com órgãos similares nos Estados Unidos (...) Um número de associados e ativistas do complexo IPES/IBAD fazia parte do seu conselho diretor (...) A associação representava um canal para a propaganda anticomunista produzida em outros países e no Brasil." DREIFUSS, René Armand, op. cit., p. 293.

${ }^{404}$ DREIFUSS, René Armand, op. cit., p. 293.
} 
1965, e seu presidente no ano de 1965, era dirigente do IPES. ${ }^{405}$ O já mencionado Dario de Almeida Magalhães também integrava a direção do IPES. ${ }^{406}$ João Nicolau Máder Gonçalvez, que integrou o Conselho Federal da OAB por todo o período democrático, com exceção do ano de 1957, é descrito por René Armand Dreifuss como um dos líderes do IPES. Formado pela Escola Superior de Guerra (ESG) em 1955, Máder Gonçalvez foi, em 1968, presidente da Associação dos Diplomados da Escola Superior de Guerra (ADESG). ${ }^{407}$ Finalmente, anote-se que Temístocles Cavalcanti, membro do Conselho Federal da OAB entre 1961 e 1962, coordenou um curso de formação política destinado a empresários e administradores organizado pelo IPES, do qual era associado. $^{408}$

Vitorioso o golpe, os integrantes do Conselho Federal foram convocados a desempenhar tarefas importantes no novo regime. Considerando, inicialmente, apenas os bacharéis pertencentes ao Conselho Federal entre o início do governo Goulart e o golpe de 31 de março, localizemos os que foram designados pelo novo regime para exercer funções-chave. Prado Kelly e Temístocles Cavalcanti foram nomeados ministros do STF. Povina Cavalcanti foi nomeado vice-presidente da Comissão Geral de Investigações (CGI). Miguel Seabra Fagundes e Temístocles Cavalcanti compuseram, ao lado do primeiro presidente da OAB, Levi Carneiro, e de Orosimbo Nonato, uma comissão nomeada, em 1966, por Castelo Branco com a incumbência de elaborar um anteprojeto de Constituição. Nehemias Gueiros foi o autor do texto do Ato Institucional $n^{\circ}$ 2. Merece destaque a atuação de Carlos Medeiros Silva, que se tornou um importante artífice do arranjo institucional da ditadura militar. Ele foi, com Francisco Campos, autor do texto do Ato Institucional $n^{\circ} 1$ e o responsável pelo anteprojeto de Constituição encaminhado pelo governo ao Congresso Nacional, no final de 1966. Medeiros ainda redigiu a Lei de Imprensa e a Lei de Segurança Nacional de

\footnotetext{
${ }^{405}$ Ibidem, p. 176.

${ }^{406}$ Ibidem, p. 124, 174.

407 Ibidem, p. 176, 404; <www.adesg.org.br/portal/institucional/presidentes/presidentes-decada-de60\#item18>. Acesso em: 11/07/2010.

${ }^{408}$ DREIFUSS, René Armand, op. cit., p. 451.
} 
1967, além de ter sido ministro do STF entre 1965 e 1966 e ministro da Justiça entre 1966 e 1967.409

Num levantamento sucinto, foi possível identificar 22 bacharéis integrantes do Conselho Federal da $\mathrm{OAB}$ durante o período democrático que exerceram cargos no Executivo Federal ou mandatos parlamentares pela ARENA nos governos Castelo Branco e Costa e Silva. Por outro lado, o mesmo levantamento identificou apenas seis integrantes do organismo no mesmo período que, até 1968, manifestaram oposição ao novo regime, foram por ele perseguidos ou filiaram-se ao MDB. ${ }^{410}$ Dentre os seis expresidentes da OAB ainda vivos em 1964, cinco desempenharam funções públicas nos primeiros anos da ditadura militar: Haroldo Valadão, Seabra Fagundes, Nehemias Gueiros, Alcino Salazar e Prado Kelly. ${ }^{411}$

As informações biográficas demonstram o engajamento dos dirigentes da $\mathrm{OAB}$ e de alguns de seus conselheiros federais mais ilustres na campanha de desestabilização do governo Goulart e na ditadura instaurada em 1964. Além disto, os dados sugerem uma ampla adesão da elite dos advogados que compusera o Conselho Federal desde 1945 ao novo regime. Seria preciso aprofundar a compreensão da participação dos bacharéis na instauração da ditadura militar. Ainda que todos estivessem impregnados do clima da Guerra Fria e sobressaltados com a ascensão da mobilização popular, é possível sugerir a existência de dois grupos distintos de bacharéis que colaboraram com o regime nos seus primeiros anos. Em primeiro lugar, os liberais tradicionais que pretendiam resguardar a democracia liberal de 1946 das crescentes demandas populares e apostavam na deposição de Goulart como uma solução emergencial e temporária. Em segundo, os autoritários modernizantes, comprometidos com a adequação da advocacia e do Direito às necessidades da modernização capitalista e alinhados a um projeto de

\footnotetext{
${ }^{409}$ Estas informações biográficas foram obtidas em: ROLLEMBERG, Denise. Memória, opinião e cultura política. A Ordem dos Advogados do Brasil sob a Ditadura (1964-1974). In: REIS, Daniel Aarão; ROLLAND, Denis. (Org.). Modernidades alternativas. Rio de Janeiro: Editora da Fundação Getúlio Vargas, 2008, p. 57-96; ABREU, Alzira Alves de et alli. (coord.), op. cit.

${ }^{410}$ As informações sobre o posicionamento dos conselheiros federais em relação à ditadura militar foram obtidas nos repertórios biográficos listados no final deste trabalho.

${ }^{411}$ Raul Fernandes era o sexto ex-presidente da Ordem ainda vivo no momento da queda de Goulart. Certamente simpático ao novo regime, não encontrei, entretanto, nenhuma referência à sua participação nos governos militares.
} 
reorganização do Estado em função da segurança nacional e do desenvolvimento econômico. $^{412}$

${ }^{412}$ Luiz Werneck Vianna também sugere a emergência de uma elite modernizante entre os bacharéis na década de 1960. Cf. VIANNA, Luiz Werneck. Os intelectuais da tradição e a modernidade: os juristaspolíticos da OAB, op. cit., p. 126-128. 


\section{CAPÍTULO IV: PERFIL INSTITUCIONAL DA OAB}

\section{1.) Dinâmica e composição do Conselho Federal}

Entre 1945 e 1964, o número de componentes do Conselho Federal variou de 57 (1946) a 81 (1963). Para este período, constatou-se uma taxa média anual de renovação no organismo de $25 \%$ (Tabela 4). Isto significa que, em média, $75 \%$ dos conselheiros já haviam participado das atividades do Conselho Federal no ano anterior, o que funcionava como um fator tanto de estabilidade nas relações de força entre os grupos internos quanto de continuidade institucional. Durante um debate, ocorrido em 12 de outubro de 1948, relativo à proibição da reeleição de dirigentes da $\mathrm{OAB}$, o conselheiro Dario Almeida Magalhães fez a defesa da estabilidade na composição do Conselho Federal:

"(...) o Conselheiro Dario de Almeida Magalhães considerando a inconveniência de se levarem tão longe esses impedimentos [de reeleição das diretorias do Conselho Federal e das seccionais], que cheguem, de futuro, a ferir a reeleição dos próprios membros do Conselho, medida certamente desrecomendável, quando se leva em conta que a permanência dos Conselheiros torna mais rígidas as decisões da Ordem, concorrendo para a unidade de sua jurisprudência disciplinar e administrativa. ${ }^{413}$

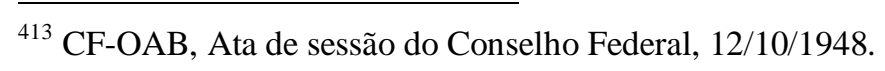


Tabela 4: Renovação na composição do Conselho Federal (1946-1964)

\begin{tabular}{|c|c|c|c|}
\hline Ano & $\begin{array}{c}\text { Número de } \\
\text { conselheiros novos } \\
\text { em relação ao ano } \\
\text { anterior }\end{array}$ & $\begin{array}{c}\text { Número total de } \\
\text { conselheiros no ano }\end{array}$ & $\begin{array}{l}\text { Percentual de } \\
\text { conselheiros novos }\end{array}$ \\
\hline 1946 & 14 & 57 & $24 \%$ \\
\hline 1947 & 18 & 58 & $31 \%$ \\
\hline 1948 & 23 & 60 & $38 \%$ \\
\hline 1949 & 23 & 65 & $35 \%$ \\
\hline 1950 & 16 & 64 & $25 \%$ \\
\hline 1951 & 19 & 75 & $25 \%$ \\
\hline 1952 & 12 & 68 & $17 \%$ \\
\hline 1953 & 21 & 65 & $32 \%$ \\
\hline 1954 & 14 & 68 & $20 \%$ \\
\hline 1955 & 15 & 63 & $23 \%$ \\
\hline 1956 & 9 & 62 & $14 \%$ \\
\hline 1957 & 16 & 63 & $25 \%$ \\
\hline 1958 & 11 & 66 & $16 \%$ \\
\hline 1959 & 19 & 69 & $27 \%$ \\
\hline 1960 & 7 & 64 & $10 \%$ \\
\hline 1961 & 15 & 59 & $25 \%$ \\
\hline 1962 & 23 & 69 & $33 \%$ \\
\hline 1963 & 26 & 81 & $32 \%$ \\
\hline 1964 & 14 & 74 & $18 \%$ \\
\hline média & & & $25 \%$ \\
\hline
\end{tabular}

Fonte: Atas do Conselho Federal da OAB, 1945-1964. 
Todavia, o grupo de advogados que comandou a $\mathrm{OAB}$ no período democrático foi relativamente numeroso. O Conselho Federal teve 280 integrantes entre 1945 e 1964. Alguns deles, como Temístocles Marcondes Ferreira, João Nicolau Máder Gonçalves, José Telles da Cruz, Francisco Gonçalvez, Antônio Carvalho Guimarães e José Maria MacDowell da Costa permaneceram no órgão durante praticamente todos estes anos. Outros estavam no Conselho desde antes de 1945. Este foi o caso de Aristeu Borges e Artur Rocha Ribeiro, conselheiros federais de 1939 a 1951 e de 1934 e 1962, respectivamente; e de Atílio Vivacqua, secretário-geral entre 1933 e 1944 e presidente do Conselho Federal no período democrático. ${ }^{414}$ Contudo, a grande maioria permaneceu no Conselho Federal por um período máximo de cinco anos (Tabela 5).

\section{Tabela 5: Permanência dos conselheiros no Conselho Federal da OAB (1945-1964)}

\begin{tabular}{ccc}
\hline $\begin{array}{c}\text { Permanência no Conselho } \\
\text { Federal }\end{array}$ & $\mathrm{N}^{\mathbf{o}}$ de conselheiros & Percentual \\
\hline 1 A 5 ANOS & 206 & $73 \%$ \\
6 A 10 ANOS & 36 & $13 \%$ \\
11 A 15 ANOS & 22 & $8 \%$ \\
16 A 20 ANOS & 16 & $6 \%$ \\
TOTAL & 280 & $100 \%$ \\
\hline Fonte: Atas do Conselho Federal da OAB, 1945-1964.
\end{tabular}

As delegações do sudeste foram as mais numerosas, reunindo quase metade dos conselheiros do período, o que se explica, talvez, tanto pela proximidade geográfica dos estados com o Rio de Janeiro quanto pelo fato de que aquela região concentrava o maior número de filiados do país (e, possivelmente, havia pressão das elites regionais de advogados para o rodízio na representação de seus estados no Conselho Federal). As delegações do nordeste foram a segunda mais numerosa, com quase um terço dos conselheiros do período.

${ }^{414}$ CF-OAB, Atas de sessão do Conselho Federal, 4/9/1951 e 13/4/1954; VIVACQUA, Atílio. In: ABREU, Alzira Alves de et alli (coord.), op. cit. 
Apesar da natureza razoavelmente fechada do Conselho Federal, os seus membros preocuparam-se em garantir o rodízio de poder nas instâncias diretivas da OAB. Na mencionada sessão de 12 de outubro de 1948, o órgão decidiu, por dois contra um terço dos votos, impedir a reeleição do presidente e do vice-presidente (o cargo ainda não existia, mas sua criação foi aprovada nesta ocasião), assim como a dos presidentes das seções estaduais. A decisão evitava a repetição das longas gestões que marcaram o primeiro decênio do Conselho Federal: Levi Carneiro comandara o órgão entre 1933 e 1938 e Fernando de Melo Viana entre 1938 e 1944. O Conselho, contudo, com dois terços dos votos, rejeitou a proposta que impediria a reeleição do secretáriogeral. ${ }^{415}$ Nota-se, não apenas que a disposição para a renovação era moderada entre os seus partidários, mas também que esta bandeira enfrentava oposição interna - evidente nos votos que recusavam a proibição de reeleição.

A busca de consenso nas eleições do Conselho Federal foi uma característica marcante do organismo desde a sua organização, no início da década de 1930. Entre 1933, ano das primeiras eleições para a presidência e secretaria-geral do Conselho Federal, e 1944, aconteceram oito eleições. Em seis delas, o presidente eleito recebeu a quase totalidade de votos. As exceções ocorreram em 1938 e 1944. Em 1938, Fernando Viana de Melo foi eleito com 13 votos contra sete angariados pelos seus três adversários para a sucessão de Levi Carneiro (eleito por quatro vezes presidente do Conselho Federal). Em 1944, em meio à conjuntura de enfraquecimento do Estado Novo, Fernando de Melo Viana derrotou o candidato da oposição liberal, Raul Fernandes, por 12 a dez votos. No entanto, Viana não foi reconduzido ao posto de bâtonnier, pois os conselheiros aprovaram uma proposta que impedia a reeleição do presidente. Ato contínuo, o candidato dos liberais assumiu o comando da entidade representativa dos advogados no país. ${ }^{416}$

Considerando o período analisado neste trabalho, observa-se que houve unanimidade na escolha do presidente e do secretário-geral nas votações de agosto de

\footnotetext{
${ }^{415}$ CF-OAB, Ata de sessão do Conselho Federal, 12/10/1948.

${ }^{416}$ VENÂNCIO FILHO, Alberto. Notícia histórica da OAB, 1930-1980, op. cit., p. 43, 47, 49-50, 52, 54, 61-62 e 67.
} 
1946, de agosto de 1954, de julho de 1956, de julho de 1958 e de julho de 1962. Nas eleições de agosto de 1952 e de julho de 1960, os candidatos aos mesmos cargos no Conselho Federal quase foram eleitos unanimemente, exceto por um voto em branco.

A eleição mais disputada do período democrático foi a que elegeu, em agosto de 1948, Pinto Lima. O candidato concorreu com Odilon de Andrade, derrotando-o por 14 votos a sete. Um mês depois, novas eleições foram convocadas em virtude da morte de Pinto Lima. Odilon de Andrade foi então eleito por unanimidade. A segunda eleição mais disputada do período foi a de agosto de 1950, na qual Haroldo Valadão venceu Arnoldo Medeiros da Fonseca por 18 votos a quatro. ${ }^{417}$

Assim, pode-se dizer que o Conselho Federal, a partir de setembro de 1948, perseguiu o consenso nas sucessões de seu comando, plenamente consolidado já no início da década de 1950. Ora, está claro que os membros do Conselho Federal queriam manter a sua coesão, evitando desta forma que as eleições dessem oportunidade para que dissensões emergissem. Em geral, o órgão preservou, igualmente, esta unidade ao se posicionar sobre questões nacionais e corporativas de relevo.

A trajetória do Conselho Federal desde a sua organização até, pelo menos, o fim do período democrático foi, portanto, marcada por uma cultura institucional que valorizava e perseguia a coesão, a estabilidade e o consenso. A pequena incidência de disputas abertas entre candidatos nas eleições para cargos diretivos reforça esta tese. Apenas nas eleições de 1944, em razão da radicalização da vida política nacional, a coesão entre os conselheiros parece ter sido verdadeiramente ameaçada. O perigo se dissipou nas eleições seguintes, em 1946, quando Raul Fernandes foi reeleito por unanimidade.

Em depoimento concedido a Alberto Venâncio Filho em junho de 1981, Alberto Barreto de Melo afirmou que o processo eleitoral habitualmente era conduzido pelo próprio secretário-geral e apontou as relações de força entre as delegações regionais:

417 CF-OAB, Atas de sessão do Conselho Federal, 12/8/1946, 11/8/1948, 14/9/1948, 11/8/1950, 11/8/1952, 3/8/1954, 31/7/1956, 29/7/1958, 26/7/1960 e 3/7/1962. 
"O processo eleitoral era geralmente comandado pelo Secretário-Geral, em busca de um consenso, na escolha do Conselheiro mais atuante. O Nordeste tinha maioria no Conselho Federal e o Norte era o fiel da balança, ambos se contrapunham à influência do Distrito Federal, tradicionalmente de grande ascendência no Conselho Federal. "418

Ainda que Alberto Barreto de Melo possa ter superestimado seu próprio papel nas sucessões da direção do Conselho Federal da Ordem dos Advogados, não há dúvidas de que ele próprio foi um dos mais marcantes elementos de continuidade do organismo, ao exercer a secretaria-geral entre 1952 e 1965. Ademais, seu testemunho é interessante por destacar a dimensão regional, que, se não era a única variável presente nas designações dos presidentes da $\mathrm{OAB}$, parece ter sido um fator importante.

Assim, merece destaque a influência do Conselho do Distrito Federal no Conselho Federal da OAB. Por décadas, ambos os órgãos dividiram as mesmas instalações. O Conselho Seccional, por funcionar na capital da República, reunia advogados de grande prestígio no país, geralmente dedicados à política ou à atuação junto aos tribunais superiores. A primeira seção da OAB a ser constituída foi a do Distrito Federal, em 6 de julho de $1932 .{ }^{419}$ Esta precedência da Seção do Distrito Federal foi reverenciada pelo Estatuto de 1933, segundo o qual o presidente e o vicepresidente do Conselho do Distrito Federal, sucessivamente, assumiriam a direção do Conselho Federal na ausência do seu presidente. ${ }^{420}$ Foi em obediência a este artigo que Pinto Lima, presidente do Conselho da Seção do Distrito Federal substituiu, em várias ocasiões, Fernando de Melo Viana e Raul Fernandes, entre 1944 e 1948. O Estatuto de 1963 aboliu este expediente, determinando que os outros integrantes da diretoria assumissem a presidência do Conselho Federal na ausência de seu titular ${ }^{421}$.

\footnotetext{
${ }^{418}$ VENÂNCIO FILHO, Alberto. Notícia histórica da $O A B$, op. cit., p. 77.

${ }^{419}$ Boletim da Ordem dos Advogados do Brasil, Rio de Janeiro, ano 28, número 28, 1962.

${ }^{420}$ Artigo 90 do Decreto ${ }^{\circ} 22.478$, de 20 de fevereiro de 1933.

${ }^{421}$ Parágrafo único do artigo $9^{\circ}$ da Lei no 4.215 , de 27 de abril de 1963. Aurélio Wander Bastos sublinha o peso do Conselho do Distrito Federal no Conselho Federal: "Assim, devido às excepcionais condições geopolíticas do Conselho do Distrito Federal, não apenas o seu peso decisório era altíssimo, como também, a advocacia da cidade do Rio de Janeiro, então capital federal, principalmente a prestigiada
} 
Há que se notar que, ao longo de toda a sua existência, o Conselho do Distrito Federal no Rio de Janeiro foi dominado por uma fração da elite da advocacia carioca. Esta situação persistiu mesmo quando, em virtude da transferência da capital federal para Brasília, a seção transformou-se em Conselho do estado da Guanabara. No momento de criação da Ordem, existia no Rio de Janeiro uma parcela da elite dos advogados que trabalhava para a Light, empresa canadense concessionária de serviços públicos, como fornecimento de energia, iluminação pública e operação de bondes. Foi justamente este grupo de advogados que se assenhoreou do Conselho do Distrito Federal e se reproduziu no seu comando, vencendo todas as eleições com a Chapa Azul. Depoimentos colhidos por Renato Lessa e Leila Linhares atestam o controle da seção do Distrito Federal pelos "advogados da Light", destacando mesmo a importância da empresa na consolidação da Ordem nos seus primeiros anos, quando a entidade enfrentava resistências entre os advogados de elite. ${ }^{422}$ Segundo Eugênio Haddock Lobo, membro do Conselho da OAB da Guanabara desde 1969 e presidente da OAB do estado do Rio de Janeiro entre 1977 e 1979:

“A Light colaborou (...) para legitimar a Ordem. Ela foi uma mola propulsora para a legitimação da Ordem numa época em que ninguém queria saber da Ordem. A Ordem nasceu em meio de um combate extremado dos grandes advogados da época”.

“(...) Não havia então uma compreensão do sentido gregário da Ordem, do sentido de defesa da classe e isto a Light compreendeu. Não tenho dúvida de que os primeiros presidentes que vieram realmente da Light, ou provindos dos postos da Light, da ingerência da Light, eles vieram com grande dose de sacrifício, enfrentando as críticas da época de seus colegas (...) Tivemos outros que morreram na tribuna aqui na Ordem, homens que se dedicaram e que vieram

advocacia dos Tribunais Superiores, tinha significativo peso no processo de decisão e orientação de posições corporativas e políticas." BASTOS, Aurélio Wander, op. cit., p. 147-148.

${ }^{422}$ LESSA, Renato; LINHARES, Leila, op. cit., p. 16, 24-25. 
das classes privilegiadas e ligadas aos grandes escritórios de advocacia da época. " 423

Para Antônio Carlos Cavalcante Maia, membro do Conselho da OAB da Guanabara desde 1964:

“(...) a Light tinha um excepcional corpo de advogados. Intelectualmente, era um núcleo de grandes advogados muito atuantes na profissão. Chamavam até de os Toronto's Boys; mas realmente, é porque havia uma coincidência, porque tinha bons advogados. Veja o Luís Antônio de Andrade, é um deles, o Rubem Ferraz, todos eles eram advogados da Light". ${ }^{424}$

Segundo José Aguiar Dias, conselheiro da Seção da OAB da Guanabara desde 1968: “Os advogados da Light tiveram uma importância muito grande na Ordem. Tiveram, porque eram uma elite, de certo modo formada arbitrariamente, mas era uma elite. E eles tomaram conta da Ordem". 425

Deve-se observar que destacados juristas-políticos e futuros udenistas, como Dario de Almeida Magalhães, Adauto Lúcio Cardoso e Heráclito Sobral Pinto estavam - ao menos, num determinado período - excluídos do grupo que dominava o Conselho do Distrito Federal. Em depoimento a Renato Lessa e a Leila Linhares, Evandro Lins e Silva narrou que, ao lado dos três, organizou, em data que não precisa, uma chapa "mais liberal" para concorrer com a Chapa Azul, "mais conservadora". Apesar da notoriedade dos seus componentes, a chapa foi derrotada. ${ }^{426}$

Dominada pelos "advogados da Light”, a Chapa Azul cooptou outros advogados de elite, vinculados a grandes escritórios de advocacia e a grandes empresas. Contudo,

\footnotetext{
423 Ibidem, p. 24-25.

424 Ibidem, p. 24.

425 Ibidem, p. 25.

${ }^{426}$ Ibidem, p. 32.
} 
tratava-se de um grupo restrito e coeso. ${ }^{427}$ Francisco Costa Neto, membro do Conselho da OAB da Guanabara desde 1974, em depoimento a Renato Lessa e Leila Linhares explicitou os mecanismos de composição da Chapa Azul:

“(...) o sentido da Chapa Azul mais antiga era o sentido um tanto elitista. A escolha, por exemplo, era uma escolha de candidatos, mediante um grupo determinado. Não entrava qualquer um facilmente. Era preciso ter uma série de conhecimentos. Eram escolhidos os filhos do advogado Fulano de Tal, que era importante. Havia também o critério segundo o qual o escritório de Fulano de Tal teria direito a uma vaga no Conselho. Havia toda uma manipulação, tipo mesmo como é nos Estados Unidos, aquele sistema fechado para se escolher os candidatos, havia isso. Era um Conselho de Notáveis. Realmente, reuniram-se quatro, cinco, seis e iam ampliando essas reuniões com outros grupos e daí surgiam os candidatos ao Conselho que eram escolhidos dessa forma". ${ }^{2} 8$

Benedito Calheiros Bonfim, eleito conselheiro da Seção da OAB da Guanabara em 1968 pela chapa de oposição, também expôs o modus operandi da Chapa Azul:

"A Ordem então, além de uma entidade corporativa, era muito fechada, restrita a um contingente de advogados limitado, onde predominavam caciques, um pequeno grupo de advogados de nome, antigos na profissão, que se reuniam no Clube dos Advogados e ali escolhiam a chapa, os advogados que seriam eleitos no biênio seguinte. Recordo-me que um deles, o líder, se chamava Couto [provavelmente Joaquim José Fernandes Couto, conselheiro federal entre 1955 e 1956 e presidente da OAB-DF entre 1955 e 1957]. Um advogado conhecidíssimo, já idoso, que com um grupo de elite organizava essas chapas e mantinha uma

\footnotetext{
427 Ibidem, p. 30-31, 39.

${ }^{428}$ Ibidem, p. 32.
} 
liderança constante da Ordem. Chamava-se a Chapa Azul. Isso era mais ou menos antes de 63. ",429

Seria interessante investigar os mecanismos que permitiam à Chapa Azul perpetuar-se, pelo voto obrigatório e direto dos advogados, na direção do Conselho do Distrito Federal e, depois, do Conselho da Guanabara. A considerar o depoimento de Helio Saboya, membro do Conselho da OAB do Rio de Janeiro desde 1978, os métodos de perpetuação no poder adotados pela Chapa Azul incluíam o voto de cabresto:

"Eu votava, recém-formado, compulsoriamente, não em função da lei que exige o voto, mas em decorrência da intervenção do Celso Fontenelle e do Astolfo Rezende que me entregavam a cédula com a Chapa Azul, no dia da eleição, e me levavam na urna para depositá-la”. ${ }^{430}$

O domínio da Chapa Azul só começou a ser abalada no final da década de 1960. Neste período, um grupo de advogados esquerdistas e liberais organizou a Chapa Renovação, que, se não conseguiu eleger o presidente do Conselho da Ordem da Guanabara, logrou eleger alguns conselheiros da seção. A base social da Chapa Renovação era formada, sobretudo, por advogados assalariados ou vinculados a sindicatos de trabalhadores. A partir de então, a corrente renovadora marcou sua presença, ainda que francamente minoritária, no Conselho da Guanabara. ${ }^{431}$

\section{2.) A missão da OAB}

A OAB era dotada de dois conjuntos de atribuições: as corporativas, de um lado, e as políticas, de outro. As corporativas desdobravam-se nas funções de seleção, disciplina e defesa da categoria profissional. A seleção era exercida pelo estabelecimento de requisitos para o exercício da advocacia (com o progressivo

\footnotetext{
${ }^{429}$ Ibidem, p. 30-31.

${ }^{430}$ Ibidem, p. 38.

${ }^{431}$ Ibidem, p. 38-39.
} 
sufocamento dos rábulas) e de impedimentos para a prática do ofício. Na década de 1960, a OAB tentará aprimorar sua função selecionadora criando o estágio profissional e o Exame da Ordem.

A disciplina da categoria profissional era exercida com ênfase pela Ordem dos Advogados, cuja cúpula praticava a vigilância rigorosa sobre a categoria profissional, com base no Código de Ética e num ideário profissional que considerava a advocacia um múnus público e repudiava o espírito mercantilista, tendo como preocupação fundamental a preservação do prestígio social dos advogados. Nos discursos dos dirigentes da $\mathrm{OAB}$, era constante a evocação do período anterior à criação da Ordem como uma época em que o reconhecimento social da advocacia era perturbado pela ampla atividade dos práticos e de advogados concupiscentes. Discursando no encontro de presidentes das seções estaduais da $\mathrm{OAB}$, realizado no âmbito da $2^{\mathrm{a}}$ Conferência Nacional da Ordem, Rui de Azevedo Sodré, da seção paulista, afirmou:

“(...) antes de 1930, a advocacia, no Brasil, apresentava aquele aspecto desolador, no tocante à disciplina e à licenciosidade então imperante (...) este era o diagnóstico daquela época, hoje, mercê da ação moralizadora da Ordem, outra é a situação da classe."

“(...) Impondo a todos os seus membros estrita observância aos preceitos do Código de Ética Profissional, cumpre a Ordem uma de suas finalidades, qual seja a de manter, em grau elevado, o prestígio da profissão. "432

Ao comemorar os 30 anos da OAB, o secretário-geral do Conselho Federal, Alberto Barreto de Melo afirmou que o efeito primordial da criação do órgão fora afastar os rábulas do exercício da profissão e emprestar prestígio à categoria profissional:

${ }_{432}$ Anais da $2^{a}$ Conferência Nacional da Ordem dos Advogados do Brasil, op. cit., p. 9 e 11. 
"A efeméride é grata aos advogados, pois nosso órgão de classe expungiu a profissão dos rábulas, disciplinou-a, selecionou-a, dignificou-a e revestiu-a da consideração social que hoje desfruta. Antes da Ordem a profissão estava inçada de práticos, tratadores de papéis forenses, aproveitadores da boa fé dos postulantes. A Ordem criou a consciência profissional, acrisolou a comunidade dos profissionais do foro, outorgou aos causídicos um estatuto que lhes atribui prerrogativas, deveres e responsabilidade." ${ }^{\prime 43}$

No $20^{\circ}$ aniversário da Ordem, o bâtonnier Haroldo Valadão já afirmara que a sua criação tinha significado "o estabelecimento de severas restrições à atividade da advocacia, para o seu aprimoramento intelectual, e, sobretudo, moral. "434 Ressaltava, deste modo, o caráter disciplinador e selecionador da Ordem, que contrastava com o livre exercício da advocacia que vigorava até $1930 .^{435}$

O Estatuto de 1933, no seu artigo 26, listava 21 práticas consideradas infrações disciplinares no exercício da advocacia. O Estatuto de 1963 intensificou a ação disciplinadora da Ordem, alargando, no seu artigo 103, o rol das infrações disciplinares para trinta práticas. Entre as infrações disciplinares previstas pelo novo estatuto estavam o desrespeito ao Código de Ética Profissional, o exercício da advocacia quando sob impedimento, o agenciamento de causas, o descumprimento a determinações da OAB e a falta de pagamento pontual das contribuições à Ordem. As penalidades previstas, no artigo 105, pelo Estatuto de 1963 ao advogado faltoso eram, além de advertência e censura, multa, exclusão do recinto, suspensão do exercício da profissão e eliminação

\footnotetext{
${ }^{433}$ CF-OAB, Ata de sessão do Conselho Federal, 4/4/1961.

${ }^{434}$ CF-OAB, Ata de sessão do Conselho Federal, 18/11/1950.

${ }^{435}$ Alcino Salazar, ao assumir, durante a $1^{\text {a }}$ Conferência Nacional da OAB, o posto de presidente da Ordem, discursou: "No que toca à disciplina, a Ordem a exerce com exclusividade em relação aos inscritos nos seus quadros. Eis aí uma de suas prerrogativas essenciais. Quando não existia a Ordem o exercício da disciplina praticamente não existia. Além das infrações cometidas perante os juízes e tribunais, as faltas cometidas no exercício da profissão ficavam sem a conveniente e adequada penalidade. Ora, a eficiência do trabalho profissional, o prestígio e autoridade do advogado, e ainda o bom nome da classe são incompatíveis com a impunidade das infrações. E é bem claro que a independência do advogado em face do juiz não se compadece com a faculdade que se atribua a este de aplicar-lhes penas." Anais da $1^{a}$ Conferência Nacional da Ordem dos Advogados do Brasil, op. cit., p. 558.
} 
dos quadros da Ordem. A pena de multa era de aplicação cumulativa com outra penalidade. Na exposição de motivos do projeto de novo estatuto, a comissão de conselheiros federais que o elaborou explicou a razão pela qual a pena de multa não poderia ser aplicada com exclusividade a um advogado faltoso, com base num argumento que revelava a concepção antimercantilista inspiradora do ideário profissional da elite dos advogados:

“A multa deixou de constituir pena autônoma, passando a ser aplicada sempre conjuntamente com outra, a fim de evitar que as transgressões disciplinares possam ser resgatadas com dinheiro, critério definidamente burguês, incompatível com o fundo ético e a teleologia da disciplina corporativa. ",436

Na década de 1950, a OAB incorporou à atribuição de defesa da categoria profissional a proteção das condições materiais de vida dos advogados. Em maio de 1954, Letácio Jansen, partindo de uma proposta do secretário-geral Alberto Barreto de Melo, propôs a criação de uma comissão permanente, em cada seccional, destinada à defesa dos interesses dos advogados, nas suas palavras, "defesa do advogado no plano econômico". Afirmou que os advogados de sua época podiam ser divididos entre aqueles que se dedicavam inteiramente à profissão e os diletantes, que tinham outros empregos e ocupações, além da advocacia. Acrescentou que a OAB devia saldar uma "velha divida" com o primeiro grupo, pois era este que sofria com as agruras por que passava a profissão. Os advogados diletantes protegiam-se destas mazelas, segundo Jansen, com as outras ocupações e empregos. Pertencente à cúpula da OAB desde a década de 1930, Jansen atacou a atuação da entidade: "Via de regra, o advogado ofendido ou atacado tem da Ordem, se à mesma recorre, um apoio convencional e simbólico." Afirmou que os advogados não tinham as garantias profissionais mais primárias: aposentadoria, tabela de honorários e serviços auxiliares ("como avisos de

\footnotetext{
${ }^{436}$ Boletim da Ordem dos Advogados do Brasil, Rio de Janeiro, volume 1, número 1, outubro 1957, p. 39.
} 
prazos e preparos $\left.{ }^{\prime \prime}\right) .{ }^{437} \mathrm{E}$ defendeu uma suavização das funções disciplinares da Ordem e uma ênfase na defesa dos interesses econômicos da categoria:

"As funções punitivas da Ordem (...) precisam ser reduzidas a justas proporções, pena de um dia, o advogado militante transformar-se em anjo, faquir ou jejuador e não em homem que vive numa época em que o fator econômico, infelizmente, é a primeira preocupação de ser vivente. O ideal da Ordem seria exercer funções paternais: defender, orientar, apoiar, estimular, e se tivesse de punir, punir com o coração sangrando." 438

Finalmente, exortou o Conselho a adotar uma plataforma sindical (aposentadoria, pensão e tabela de honorários), além de tornar "úteis as Caixas de Advogado, que hoje são apenas monumentos arquitetônicos. " 439

Esta proposta de Letácio Jansen desvela uma concepção sindical da OAB, preocupada com os interesses da base da categoria dos advogados. Ela se chocava com a missão ética concebida pela maioria dos conselheiros - eles próprios pertencentes à elite da categoria profissional -, menos sensibilizados com as dificuldades do advogado comum. A concepção ética considerava a OAB uma "força moral", um "baluarte da ordem jurídica". À maioria dos conselheiros devia repugnar a idéia de uma atuação sindical da Ordem. Letácio Jansen, que já se destacara na defesa do projeto de lei sobre a aposentadoria para os advogados, emergia, no interior do Conselho Federal, como um porta-voz dos interesses do baixo clero dos advogados.

A proposta de Jansen apenas foi aprovada - ainda que unanimemente - em outubro de $1956 .{ }^{440}$ A agenda sindical já havia, então, se imposto ao Conselho Federal. Prova disto é o discurso de posse de Miguel Seabra Fagundes na presidência da OAB, em agosto de 1954, no qual o novo bâtonnier reconhecia que ainda havia muito o que fazer no campo da proteção social ao advogado e exortava a categoria profissional a

\footnotetext{
${ }^{437}$ CF-OAB, Ata de sessão do Conselho Federal, 25/5/1954.

${ }^{438}$ CF-OAB, Ata de sessão do Conselho Federal, 25/5/1954.

${ }^{439}$ CF-OAB, Ata de sessão do Conselho Federal, 25/5/1954.

${ }^{440}$ CF-OAB, Ata de sessão do Conselho Federal, 2/10/1956.
} 
exigi-la do Estado: "Já é tempo do trabalhador liberal reivindicar do Estado o tratamento, que uma visão parcial das atividades profissionais tem relegado à omissão. " ${ }^{441}$ E, antecipando-se às críticas de sensibilidade liberal, completava:

"Isso não implica em dependência moral ou econômica do poder, que no concernente à advocacia é incompatível com a sua própria essência, senão no apelo a fórmulas que, pairando no campo do seguro social, se podem tornar extensivas ao advogado, como a quaisquer outros profissionais liberais, sem interferência com a autonomia que lhes é peculiar. ${ }^{442}$

Como Letácio Jansen, Seabra Fagundes reconhecia as dificuldades econômicas que se abatiam sobre a base da categoria profissional:

“(...) muitos profissionais há nos Estados e aqui mesmo, a maioria de certo, que dela mal retiram o indispensável. Somente uma minoria vive, hoje, ao abrigo das inquietações a que o curso da vida pode, de momento, lançar qualquer um de nós, pela impossibilidade de produzir. Somente uma minoria se guarda tranquila em relação ao futuro econômico da família sobrevivente. ${ }^{443}$

O Estatuto de 1963 sacramentou a incorporação da função sindical pela OAB, ao estabelecer, no seu primeiro artigo, que cabia ao órgão representar, em qualquer instância, "os interesses gerais da classe dos advogados e os individuais, relacionados com o exercício da profissão."

$\mathrm{O}$ engajamento do Conselho Federal da OAB no combate ao Estado Novo consolidou a atribuição de protetor da ordem jurídica assumida pelo organismo. Note-se que o Estatuto da Ordem dos Advogados de 1933 lhe atribuía funções estritamente corporativas. A OAB terá o reconhecimento legal de seu papel de defensora da ordem

\footnotetext{
${ }^{441}$ CF-OAB, Ata de sessão do Conselho Federal, 11/8/1954.

${ }^{442}$ CF-OAB, Ata de sessão do Conselho Federal, 11/8/1954.

${ }^{443}$ CF-OAB, Ata de sessão do Conselho Federal, 11/8/1954.
} 
jurídica apenas com a aprovação, em 1963, do seu novo estatuto, o qual, nos seus artigos 18 e 27, estabelecia que cabia tanto ao Conselho Federal da Ordem quanto aos advogados a defesa da ordem jurídica e da Constituição Federal.

De todo modo, o Conselho Federal demonstrou-se sempre cioso de preservar o seu papel político. ${ }^{444} \mathrm{O}$ argumento fundamental desta posição era o de que a atuação profissional do advogado dependia da manutenção da ordem jurídica. Nas palavras de Dario de Almeida Magalhães:

"Quando se atinge, por um ato de arbítrio, a ordem jurídica ou a legalidade, o que se está solapando ou destruindo é a própria razão de ser da profissão do advogado e do papel do jurista, e, por isso mesmo, nunca se entendeu que a missão de um e de outro e os deveres correspondentes se confinassem num âmbito angusto da atividade profissional cotidiana. "445

E, usando um argumento que estivera presente no manifesto de apoio dos advogados a Eduardo Gomes, em 1945, o conselheiro federal da OAB mencionou o caráter especial da advocacia, relacionada com todas as grandes questões públicas:

"Não é esta a tradição da nossa profissão, nem jamais se compreendeu que de tal forma se deveria amesquinhar o papel do advogado e do jurisconsulto, equiparando-o ao de outras profissões que não têm o mesmo relevo ou a mesma influência cívica, porque, na verdade, o advogado deve interessar-se por tudo o que diz respeito ao meio social, no que se refere à sua organização, à sua estrutura, à vida pública, às prerrogativas, aos direitos e aos interesses coletivos dos cidadãos. ${ }^{446}$

\footnotetext{
${ }^{444}$ Nas solenidades do Conselho Federal da $\mathrm{OAB}$, os seus dirigentes insistiam na atribuição à Ordem de um papel político. Haroldo Valadão, por exemplo, na comemoração do $20^{\circ}$ aniversário da Ordem, sublinhou sua ação em prol "da sempre melhor realização da justiça, da defesa da ordem democrática e do bem da pátria" CF-OAB, Ata de sessão do Conselho Federal, 18/11/1950.

${ }^{445}$ CF-OAB, Ata de sessão do Conselho Federal, 17/8/1948.

${ }^{446}$ CF-OAB, Ata de sessão do Conselho Federal, 17/8/1948.
} 
No final da década de 1940, um grupo de membros do Conselho Federal articulou uma proposta para limitar os pronunciamentos públicos do organismo. Sua aprovação acarretaria, evidentemente, o enfraquecimento da ação política do organismo. Contudo, a proposta foi largamente derrotada. Os argumentos expostos, na ocasião, por Dario de Almeida Magalhães basearam a decisão da maioria. De acordo com o conselheiro federal, a legitimidade da ação extracorporativa da $\mathrm{OAB}$ estava fundada na luta contra o Estado Novo, o que afirmou referindo-se

“a precedentes da questão em debate e justificou o procedimento da Ordem quando, no período de supressão das liberdades públicas, defendeu, com desassombro e energia, as prerrogativas inalienáveis dos advogados, atingidas pelos atos do governo ditatorial lesivos à ordem jurídica”, ${ }^{447}$

Dario Magalhães considerou ainda que a redução de sua atividade política causaria prejuízo "do prestígio e da autoridade moral da Ordem". ${ }^{448}$ A temática da "autoridade moral" era recorrente nos pronunciamentos da cúpula da OAB. Aprimorando o exercício da advocacia, no âmbito corporativo, e defendendo, no plano político, um bem comum - a ordem jurídica, a entidade, acreditavam seus dirigentes, angariava reconhecimento dos advogados, do conjunto da sociedade e, mesmo, do Estado. Como afirmou Rui de Azevedo Sodré na $2^{\text {a }}$ Conferência Nacional da Ordem:

"Granjeou ela prestígio perante os poderes constituídos, a opinião pública e a própria classe, a ponto de se reconhecer, como melhor galardão dos seus méritos, que a 'Ordem dos Advogados do Brasil não pertence aos advogados, mas à justiça e consequentemente à Nação'., "449

\footnotetext{
${ }^{447}$ CF-OAB, Ata de sessão do Conselho Federal, 28/9/1948.

${ }^{448}$ CF-OAB, Ata de sessão do Conselho Federal, 28/9/1948.

${ }^{449}$ Anais da $2^{a}$ Conferência Nacional da Ordem dos Advogados do Brasil, op. cit., p. 10.
} 
É verdade que em relação à categoria profissional, a Ordem dispunha de poder de coerção. Porém, a sua força junto ao Estado e à sociedade dependia (ainda que não exclusivamente, porque ela também derivava da intensa participação dos advogados na direção do Estado e dos seus vínculos com as classes dominantes) de seu prestígio como organismo devotado a causas coletivas.

Ainda no período democrático, o Conselho Federal buscou alargar a sua atuação política. Já não se tratava, mais, de apenas reagir às investidas estatais contra a ordem jurídica, mas, também, de contribuir para o seu aprimoramento. Assim, a $2^{\text {a }}$ Conferência Nacional da $\mathrm{OAB}$ recomendou a participação das entidades de advogados na elaboração das leis e fez várias sugestões para a melhoria do funcionamento da justiça no país. A atribuição política estendida foi reconhecida pelo Estatuto de 1963, que listou, no seu artigo 18, entre os objetivos da Ordem "pugnar pela boa aplicação das leis e pela rápida administração da justiça e contribuir para o aperfeiçoamento das instituições jurídicas. ",450

\footnotetext{
${ }^{450}$ Ao assumir a presidência da OAB, em agosto de 1958, Alcino Salazar pontuou: "Cumpre, ainda, à corporação [a Ordem dos Advogados], como aos advogados individualmente, no plano superior das atividades do Estado, colaborar na elaboração e aplicação das leis." Anais da $1^{a}$ Conferência Nacional da Ordem dos Advogados do Brasil, op. cit., p. 559.
} 


\section{CAPÍTULO V: PERFIL DOS CONSELHEIROS FEDERAIS}

\section{1.) Os bâtonniers do período democrático}

Dez bacharéis estiveram à frente do Conselho Federal da Ordem dos Advogados no período estudado. Estes bacharéis, que chegaram ao comando da corporação em idade madura, em média aos 58 anos, pertenciam, em sua maioria, a oligarquias regionais ou a famílias com tradição nas carreiras jurídicas, ou possuíam ambas as origens. A quase todos cabe o epíteto de "homens públicos", já que desempenharam, nos três poderes, funções ligadas à condução do Estado. Parte deles esteve vinculada à vida partidária. Vários deles apoiaram a Aliança Liberal na tomada do poder e exerceram cargos no governo revolucionário, embora alguns tenham rompido com Vargas por ocasião da instalação do Estado Novo, em 1937. No período democrático, os que tinham engajamento partidário vincularam-se à UDN, exceção feita a Atílio Vivacqua. Ao menos metade deles, apoiou a candidatura presidencial de Eduardo Gomes, em 1945. No mais, eram bacharéis renomados no campo profissional, como advogados, juristas ou professores de faculdades de Direito prestigiadas. ${ }^{451}$

Em termos de origens regionais, sete presidentes provinham do Sudeste e três do Nordeste. Note-se a força política da primeira região em relação à segunda, evidente quando se lembra que o Nordeste tinha quase o dobro dos votos no Conselho Federal em relação ao Sudeste (nove delegações contra cinco - incluindo o Distrito Federal e, depois, a Guanabara). ${ }^{452}$

\footnotetext{
${ }^{451}$ Os dados biográficos dos presidentes da OAB foram levantados nas seguintes obras: ABREU, Alzira Alves de et alli (coord.), op. cit.; MICELI, Sergio. Carne e osso da elite política brasileira pós-1930, op. cit.; BONELLI, Maria da Glória, op. cit.; BENEVIDES, Maria Victoria de Mesquita, op. cit.; OLIVEIRA, João Gualberto de, op. cit.; VENÂNCIO FILHO, Alberto. Notícia histórica da OAB, op. cit. ${ }^{452}$ Como se vê, não procede a afirmação de Laudo Camargo, presidente da Ordem entre 1969 e 1971, de que, até 1968, a maioria dos presidentes do Conselho Federal haviam sido originários do nordeste: "Segundo Laudo Camargo, o nordeste sempre fora unido no Conselho Federal, razão pela qual conseguira eleger a maioria dos seus presidentes, mesmo num período em que a grande concentração dos advogados já se encontrava em São Paulo. Considerando tal situação insustentável, durante a realização da III Conferência da Ordem, a representação de São Paulo, aliada a Samuel Duarte, 'procurou estabelecer contatos com as demais representações do sul do país' em nome da modernização
} 
Com exceção de Raul Fernandes, todos os presidentes, antes de serem eleitos para comandarem a Ordem, haviam pertencido ao Conselho Federal, o que é mais um elemento a revelar o caráter fechado deste organismo. Desvenda-se, desse modo, uma condição necessária para ser eleito bâtonnier: pertencer ou já haver pertencido aos quadros do Conselho Federal. Tratava-se, portanto, de uma escolha interpares.

Raul Werneck Fernandes, nascido em Valença (Rio de Janeiro), em 1877, provinha, do lado materno, de uma tradicional família de cafeicultores de Vassouras. Era neto, também pelo lado materno, do visconde de Ipiabas. Seu pai foi deputado, senador estadual e presidente das Câmaras Municipais de Valença e Vassouras. Formado pela Faculdade de Direito de São Paulo em 1898, instalou, em 1906, seu escritório de advocacia no Rio de Janeiro, tendo como cliente a empresa Guinle \& Cia. Ainda na Primeira República, iniciou sua carreira política, sendo eleito vereador e deputado estadual no Rio de Janeiro, e, em seguida, deputado federal. Ao mesmo tempo, foi incumbido de várias missões diplomáticas na Europa e nas Américas. Correligionário de Nilo Peçanha, apoiou a Revolução de 1930. Atuou como consultorgeral da República em 1932 e integrou o Conselho Consultivo do Estado do Rio entre 1930 e 1934. Foi deputado na Assembleia Nacional Constituinte de 1934, eleito pelo Partido Popular Radical (PPR), que congregava a antiga corrente nilista. Depois, exerceu mandato na Câmara dos Deputados até 1937, durante o qual foi líder da maioria (governista) e candidato oficial do governo à presidência daquela casa legislativa, em 1936, embora tenha sido derrotado. Neste período, foi também diretor da Companhia Pirelli. Foi um dos fundadores da UDN, mas antes, segundo o testemunho de Ernani Amaral Peixoto, manteve entendimentos para ingressar no PSD. Ainda em 1945, assumiu a presidência da seção fluminense da UDN. No período democrático, foi, por duas vezes, chanceler: no governo Dutra e no governo Café Filho. Publicou, entre outros, os livros como A paz pela escola e $O$ problema do café. ${ }^{453}$

da entidade.' " VIANNA, Luiz Werneck; VIANNA, Maria Lucia Teixeira Werneck, op. cit., p. 119. Até 1968, a OAB tivera 15 presidentes: dez eram originários do Sudeste e cinco do Nordeste.

${ }^{453}$ OLIVEIRA, João Gualberto de, op. cit., p. 354-356; BENEVIDES, Maria Victoria de Mesquita, op. cit., p. 26; CARVALHO, Antônio Gontijo de, op. cit; PECHMAN, Robert. FERNANDES, Raul. In: ABREU, Alzira Alves de et alli. (coord.), op. cit. 
Monarquista convicto, Augusto Pinto Lima nasceu em 1874, filho do barão de Pinto Lima, presidente da província do Rio de Janeiro no Império. Em 1893, ainda estudante de Direito, defendeu, na justiça, participantes da Revolta da Armada. Em 1932, apoiou a Revolução Constitucionalista. Lecionou Economia Política na Faculdade Livre de Direito do Rio de Janeiro, onde havia se formado, em 1894. Foi presidente do IAB por dois mandatos (1933-1935 e 1939-1941) e da seção da OAB do Distrito Federal entre 1943 e 1948 - o que demonstra o seu pertencimento à Chapa Azul. Exerceu a advocacia, inclusive no Tribunal do Júri, por mais de 50 anos. Em 1945, foi um dos oradores da sessão de fundação da UDN e apoiou a candidatura de Eduardo Gomes. Publicou os livros Reorganização municipal do Distrito Federal (1925), Processo penal (1931) e Alberto Torres e a reforma da Constituição (1933). ${ }^{454}$

Odilon Barrot Martins de Andrade nasceu em Andrelândia (MG), em 1876. Formado pela Faculdade de Direito de São Paulo, em 1894, foi promotor, juiz, vereador e presidente da Câmara Municipal em São João Del Rey (MG). Ainda na Primeira República, exerceu, como representante de seu estado natal, dois mandatos de deputado federal. Foi professor de Processo Judiciário Civil na Faculdade de Direito da Universidade do Rio de Janeiro e autor de Comentários ao Código de Processo Civil e Comentários ao Código de Processo do Distrito Federal. Depois de exercer a presidência da OAB, foi presidente da seção da OAB da Guanabara (1961-1962). ${ }^{455}$

Haroldo Teixeira Valadão, nascido em São Paulo, em 1901, era filho de Alfredo Valadão, destacado jurista e ministro do Tribunal de Contas da União (TCU), entre 1916 e 1935. Formou-se, em 1921, na Faculdade de Ciências Jurídicas e Sociais do Distrito Federal. Durante o governo Vargas exerceu cargos públicos de relator da Comissão Legislativa de Imigração e Naturalização (1931-1933), membro do Conselho Penitenciário (1933), procurador criminal da República no Distrito Federal (a partir de 1933) e procurador regional eleitoral (a partir de 1934). Em 1945, apoiou a candidatura

\footnotetext{
${ }^{454}$ OLIVEIRA, João Gualberto de, op. cit., p. 354; BONELLI, Maria da Gloria, op. cit., p. 80-81; VENÂNCIO FILHO, Alberto. Notícia histórica da OAB, op. cit., p. 73; Diário Carioca, 28/6/1945, p. 11; O Jornal, 1/9/1948, $2^{\text {a }}$ seção, p. 1 e 4; Correio da Manhã, 1/9/1948, p. 2.

${ }^{455}$ OLIVEIRA, João Gualberto de, op. cit., p. 356; VENÂNCIO FILHO, Alberto. Notícia histórica da $O A B$, op. cit., p. 77.
} 
presidencial de Eduardo Gomes e, em 1960, a candidatura a vice-presidente do udenista Milton Campos. Pouco antes de assumir a presidência da OAB, foi consultor-geral da República no governo Dutra. Entre 1944 e 1946, presidiu o IAB. Lecionou Direito Internacional Privado na Universidade do Brasil e na Pontifícia Universidade Católica do Rio de Janeiro (PUC-RJ) e é autor de livros, entre os quais Estudo de Direito internacional privado (1947) e O Direito latino-americano (1954). Ademais, foi ministro do Tribunal Superior Eleitoral (TSE), entre 1955 e 1959, e procurador-geral da República no ano de 1967,durante o governo Costa e Silva. ${ }^{456}$

Atílio Vivacqua, filho de um fazendeiro e comerciante, nasceu em Muniz Freire (ES), em 1894. Formou-se pela Faculdade Livre de Direito do Rio de Janeiro em 1916. Na década de 1920, foi, por três mandatos, deputado estadual no Espírito Santo, assim como secretário de Instrução Pública no mesmo estado. Em 1934, foi eleito deputado junto à Assembléia Constituinte capixaba. Durante o Estado Novo, foi procurador da Justiça do Trabalho, consultor jurídico interino do Ministério do Trabalho, Indústria e Comércio e consultor jurídico da Companhia Siderúrgica Nacional (CSN). Em 1945, participou da fundação do PSD, legenda pela qual se elegeu senador constituinte. Em 1946, transferiu-se para o Partido Republicano (PR) - agremiação nascida de uma dissidência da UDN. Foi senador até a sua morte, em 1961. No Senado, destacou-se na defesa dos interesses da cafeicultura. Foi presidente do Clube dos Advogados e vicepresidente do Instituto dos Advogados do Espírito Santo. Publicou várias obras, como $A$ escola ativa brasileira (1930) e A questão do imposto em espécie sobre o café (1932). ${ }^{457}$

Miguel Seabra Fagundes nasceu em Natal (RN) no ano de 1910. Ainda estudante, apoiou a Revolução de 1930 e, dois anos depois, formou-se pela Faculdade de Direito do Recife. No início da década de 1930, militou na Ação Integralista Brasileira (AIB). Foi oficial de gabinete do interventor federal, Irineu Joffily (1930-

\footnotetext{
${ }^{456}$ OLIVEIRA, João Gualberto de, op. cit., p. 356-357; VALADÃO, Haroldo. In: ABREU, Alzira Alves de et alli. (coord.), op. cit; VENÂNCIO FILHO, Alberto. Notícia histórica da OAB, op. cit., p. 85; MELO, Luís Correia de. Dicionário de autores paulistas. São Paulo: Comissão do IV Centenário da Cidade de São Paulo, 1954, p. 647; COUTINHO, Afrânio. Brasil e brasileiros de hoje. Rio de Janeiro: SulAmericana, 1961, p. 586-587; Diário de Notícias, 11/8/1960, $1^{\text {a }}$ seção, p. 1-2.

${ }^{457}$ OLIVEIRA, João Gualberto de, op. cit., p. 357-358; VIVACQUA, Atílio. In: ABREU, Alzira Alves de et alli. (coord.), op. cit.
} 
1931), delegado-auxiliar do chefe de polícia (1932), procurador do Tribunal Regional Eleitoral (TRE) (1932) e desembargador do Tribunal de Justiça (a partir de 1935), sempre no Rio Grande do Norte. No governo José Linhares, foi interventor federal no seu estado natal. Foi consultor-geral da República no governo Dutra. Em 1950, exonerou-se da função de desembargador e mudou-se para a capital da República, onde passou a advogar. Em 1952, foi convidado a fazer parte do conselho técnico da Confederação Nacional do Comércio (CNC). No ano seguinte, tornou-se membro do conselho da OAB do Distrito Federal. Licenciou-se da presidência da OAB para assumir, logo depois do suicídio de Vargas, o Ministério da Justiça. Ocupou o cargo até fevereiro de 1955, quando se demitiu por discordar do presidente Café Filho, a quem acusava de ser complacente com a tentativa dos ministros militares de inviabilizarem a candidatura presidencial de Juscelino Kubitscheck. Em 1966, integrou uma comissão nomeada por Castelo Branco para elaborar um anteprojeto constitucional que incorporasse à Constituição de 1946 a legislação de exceção decretada desde o golpe de 1964. Em 1968, posicionou-se contra o AI-5. Foi autor de Da desapropriação no Direito brasileiro (1942) e As forças armadas e a Constituição (1955), entre outros. Presidiu o IAB, entre 1970 e $1972 .^{458}$

Nehemias da Silva Gueiros, nascido em Natal (RN), em 1907, diplomou-se pela Faculdade de Direito do Recife, no mesmo ano que Seabra Fagundes, seu conterrâneo. Em 1945, participou da fundação da UDN e, em 1965, da elaboração do AI-2, tendo, inclusive, redigido sua introdução. Autor dos livros Da condição em face do Código Civil (1935) e Capacidade da mulher casada (1941), lecionou Direito Civil na Faculdade de Direito do Recife. ${ }^{459}$

Alcino de Paula Salazar, nasceu em São João de Manhaçu (MG), em 1897, e bacharelou-se pela Faculdade de Direito de Belo Horizonte, em 1919. Ainda antes da Revolução de 1930, foi vereador, presidente da Câmara Municipal e prefeito da sua

\footnotetext{
${ }^{458}$ OLIVEIRA, João Gualberto de, op. cit., p. 358; CALICCHIO, Vera. FAGUNDES, Seabra. In: ABREU, Alzira Alves de et alli. (coord.), op. cit; CF-OAB, Ata de sessão do Conselho Federal, 31/8/1954; VENÂNCIO FILHO, Alberto. Notícia histórica da OAB, op. cit., p. 94.

459 OLIVEIRA, João Gualberto de, op. cit., p. 358-359; BENEVIDES, Maria Victoria de Mesquita, op. cit., p. 27.
} 
cidade natal. Foi professor de Direito Civil na Faculdade Nacional de Direito. Em 1945, apoiou a candidatura presidencial de Eduardo Gomes. Ligado à Chapa Azul, presidiu a seção do Distrito Federal da OAB entre 1949 e 1951. Entre 1963 e 1965, foi secretário de Justiça da Guanabara, durante o governo de Carlos Lacerda. Atuou como procuradorgeral da República, entre 1965 e 1967, no governo Castelo Branco. Publicou, entre outros livros, Reparação do dano moral e Conceito do ato administrativo. ${ }^{460}$

José Eduardo do Prado Kelly, nascido em Niterói, em 1904, era filho de Otávio Kelly, deputado estadual fluminense na Primeira República e ministro do STF no governo Vargas. Graduou-se no Rio de Janeiro, em 1925. Recém-formado, abriu um escritório de advocacia, ao mesmo tempo em que trabalhava como editor do jornal $A$ Noite. Apoiou a Revolução de 1930 e exerceu funções públicas nos primeiros anos do novo regime, como redator-chefe do Departamento Oficial de Publicidade e secretário da Imprensa Nacional. Neste período, assumiu, ao lado do general Cristóvão Barcelos, a liderança da União Progressista Fluminense (UPF), partido que disputava a hegemonia política no Rio de Janeiro com o PPR de Raul Fernandes. Entre 1933 e 1934, foi deputado federal constituinte, eleito pela UPF e entre 1935 e 1937, exerceu mandato de deputado federal pelo Rio de Janeiro. Entre 1936 e 1937, atuante na oposição a Vargas, apoiou a candidatura presidencial de Armando Sales de Oliveira e aderiu à União Democrática Brasileira (UDB). A partir de 1943, esteve no centro das articulações para a criação da UDN, partido pelo qual participou em 1946 da Assembléia Nacional Constituinte, eleito pelo Rio de Janeiro. Entre 1948 e 1950, foi presidente nacional da UDN. Nesta legenda, cumpriu mais dois mandatos como deputado federal, novamente pelo Rio de Janeiro, entre 1946 e 1951 e entre 1955 e 1959. Em 1955, foi ministro da Justiça do governo Café Filho. Presidiu a seção da OAB do Distrito Federal (19591960) - o que revela o seu vínculo com a Chapa Azul. Em 1965, foi nomeado ministro

${ }^{460}$ OLIVEIRA, João Gualberto de, op. cit., p. 359; SALAZAR, Alcino. In: ABREU, Alzira Alves de et alli. (coord.), op. cit. 
do STF por Castelo Branco. Dentre os vários livros que publicou estão Direito Constitucional (1966) e Missão do advogado (1977). ${ }^{461}$

Carlos Povina Cavalcanti nasceu em União dos Palmares (AL), em 1898, e formou-se pela Faculdade de Direito do Recife, em 1918. Foi deputado estadual em Alagoas, procurador-geral e consultor jurídico da prefeitura do Distrito Federal (Rio de Janeiro). Em 1945, apoiou a candidatura presidencial de Eduardo Gomes. ${ }^{462}$

\section{2.) Perfil dos conselheiros federais}

Ao pesquisar em repertórios biográficos, obtive informações sobre a vida de 189 dentre os 280 conselheiros federais no período 1945-1964, incluindo os presidentes e secretários-gerais - o que representa $67,5 \%$ do total de integrantes do Conselho Federal durante o período analisado nesta tese. É esta amostragem que alicerça o estudo do perfil dos conselheiros que se segue. ${ }^{463}$ A não ser indicação em contrário, os percentuais apresentados abaixo referem-se a este universo de 189 conselheiros sobre os quais obtive informações biográficas. Outra advertência necessária é que os dados referem-se à situação anterior e do momento em que os conselheiros exerciam a sua função no Conselho Federal. Noutras palavras, as informações referem-se à trajetória dos conselheiros até o momento em que desempenharam atividades junto ao Conselho Federal da OAB.

\footnotetext{
${ }^{461}$ OLIVEIRA, João Gualberto de, op. cit., p. 360-361; MICELI, Sergio. Carne e osso da elite política brasileira pós-1930, op. cit., p. 586-587; BENEVIDES, Maria Victoria de Mesquita, op. cit., p. 26; DIAS, Sônia. KELLY, Prado. In: ABREU, Alzira Alves de et alli. (coord.), op. cit.

${ }^{462}$ OLIVEIRA, João Gualberto de, op. cit., p. 361; Diário Carioca, 28/6/1945, p. 11.

${ }^{463}$ A principal fonte documental para perfilar os integrantes do Conselho Federal da OAB foram os dicionários biográficos citados no final desta tese. Acessoriamente, as próprias atas de reuniões do Conselho Federal ofereceram elementos para que se traçasse o perfil biográfico dos conselheiros. Entretanto, trata-se, em geral, de informações um tanto vagas e incompletas. Os dados biográficos aparecem, sobretudo, em pronunciamentos sobre a morte de conselheiros ou sua entronização em cargos importantes, no magistério superior, na magistratura ou mesmo na política.
} 


\section{a.) Estado natal e local de formação}

Todas as unidades da federação tinham representantes no Conselho Federal no período estudado. Na grande maioria dos casos, os conselheiros eram delegados dos estados onde haviam nascido. Podemos daí inferir que, mesmo que alguns tenham se bacharelado e feito carreira fora de seu estado de origem, eles mantinham vínculos com os círculos jurídicos de sua terra natal, pois cabia às seções estaduais da $\mathrm{OAB}$ indicar os seus representantes no Conselho Federal. De todo modo, os integrantes do Conselho Federal, no exercício de seus mandatos, moravam no Rio de Janeiro. ${ }^{464}$ Alguns conselheiros fixaram-se na cidade para advogar, depois de formados ou aposentados da magistratura. Outros foram para a capital federal a fim de exercer cargos públicos. Poucos haviam nascido lá.

Os conselheiros federais do período democrático nasceram entre as décadas de 1870 e 1920. Porém, a grande maioria deles nasceu entre as décadas de 1880 e 1910. Tem-se o ano de nascimento de 139 conselheiros: 4,3\% nasceram na década de 1870; $14,3 \%$ na de $1880 ; 23,7 \%$ na de $1890 ; 28,7 \%$ na de $1900 ; 23,7 \%$ na de 1910 e $5 \%$ na de 1920.

Obtive as datas de formação de 124 conselheiros federais. Cerca de 2/3 deles diplomaram-se durante a Primeira República ao passo que o restante formou-se nas décadas de 1930 e 1940. Observa-se, deste modo, que grande parte dos conselheiros iniciou a vida profissional e política antes da Revolução de 1930, ainda que um número significativo o tenha feito posteriormente.

A elite jurídica que comandou a $\mathrm{OAB}$ no período analisado teve origem acadêmica razoavelmente diversificada. Formou-se no Rio de Janeiro, em São Paulo, em Minas Gerais, na Bahia, em Pernambuco, no Ceará, no Amazonas, no Pará, em Goiás, no Paraná, no Rio Grande do Sul e em Santa Catarina. A maioria dos conselheiros federais frequentou instituições de ensino situadas nas capitais destes estados. A disseminação dos cursos de Direito pelo país permitia que as elites

\footnotetext{
${ }^{464}$ Um boletim do Conselho Federal de 1957 trazia a relação dos endereços dos conselheiros federais: todos eles ficavam na cidade do Rio de Janeiro. Boletim da Ordem dos Advogados do Brasil, Rio de Janeiro, volume 1, número 1, outubro 1957, p. 3-4.
} 
formassem seus filhos nos seus estados ou, ao menos, nas suas regiões de origem. As faculdades do Rio de Janeiro foram responsáveis pela formação de quase metade dos conselheiros federais, originários de todas as regiões do país. A Faculdade de Direito do Recife mantinha sua influência regional, formando não somente bacharéis nascidos em Pernambuco, mas também oriundos de outros estados do Norte e Nordeste. Em terceiro lugar, em termos de importância numérica na formação dos conselheiros, vinham os cursos de Direito de São Paulo, Bahia e Minas Gerais.

Os membros do Conselho Federal bacharelaram-se num período em que as instituições oficiais, especialmente as Faculdades de Direito de São Paulo e do Recife, não mais detinham o monopólio da formação dos bacharéis brasileiros - como ocorrera durante todo o Império. E, o que é menos evidente, numa época em que, a julgar pelos dados acima, testemunhava-se a diminuição da importância destas duas tradicionais instituições de ensino (sobretudo da Faculdade de Direito de São Paulo) na formação da cúpula dos bacharéis brasileiros. Por outro lado, os mesmos dados sugerem que as faculdades de Direito fluminenses tornaram-se o celeiro da elite jurídica brasileira durante a primeira metade do século XX. A origem acadêmica dos presidentes da $\mathrm{OAB}$ neste período respalda esta tese: quatro formaram-se em instituições fluminenses; três na Faculdade de Direito do Recife; dois na Faculdade de Direito de São Paulo e um na Faculdade de Direito de Minas Gerais.

\section{b.) Atividades profissionais}

Acompanhando a trajetória dos conselheiros da Ordem, percebe-se que, ao se formarem, seguiram para as atividades políticas (ocupando cargos no Executivo ou exercendo mandatos parlamentares), as carreiras jurídicas (advocacia, magistratura e promotoria), o magistério superior ou o jornalismo. O mais comum era que o bacharel combinasse mais de um destes caminhos colocados à sua disposição. Em geral, ele seguia, sequencialmente ou simultaneamente, mais de uma carreira, sendo raros os que se devotavam a apenas uma das atividades tradicionalmente reservadas às levas de estudantes saídos dos cursos jurídicos. 
Cerca de um terço dos conselheiros federais seguiu uma das carreiras jurídicas estatais - na magistratura ou no Ministério Público. O ingresso na carreira se deu mais frequentemente na Primeira República (32 conselheiros), mas também durante o governo Vargas (19 conselheiros) e raramente (apenas três conselheiros) no pós-1945. É certo que parte destes bacharéis deixou, em determinado momento, a magistratura ou a promotoria, ou, o que era mais comum, exerceram-nas paralelamente a outras atividades. Segundo o testemunho de Alberto Barreto de Melo - personagem central no Conselho Federal durante o período democrático -, em meados da década de 1940, o Conselho Federal era composto, em parte, por desembargadores aposentados, especialmente do Norte e Nordeste, que haviam se transferido para o Rio de Janeiro. ${ }^{465}$

Antônio Manuel de Carvalho Neto foi um dos conselheiros da OAB que passaram pela magistratura ainda na Primeira República. Membro da representação do Sergipe no Conselho Federal entre 1950 e 1953, nasceu neste estado em 1889 e formouse pela Faculdade Livre de Direito do Rio de Janeiro. Seu pai, Joviano Joaquim de Carvalho, era médico e foi deputado federal de 1900 a 1914. Recém-formado, Carvalho Neto foi trabalhar no escritório de advocacia do romancista Herculano Inglês de Sousa, no Rio de Janeiro. Depois de exercer um mandato como deputado estadual em seu estado natal, atuou como juiz de direito em cidades do interior sergipano, entre 1913 e 1916. Em 1921, voltou à vida partidária pelas mãos do Partido Conservador do Sergipe, elegendo-se deputado federal no mesmo ano. ${ }^{466}$ Já Artur Ferreira da Costa, que representou o Paraná e Santa Catarina no Conselho Federal de 1945 a 1947, desempenhou a função de promotor público em Joinville (Santa Catarina) entre 1910 e 1913. Costa nasceu em 1887 e formou-se pela Faculdade de Direito da Bahia. Vinculado ao Partido Republicano Catarinense, cumpriu mandatos de deputado estadual em Santa Catarina entre 1913 e 1928. Com a vitória da Revolução de 1930, deixou o cargo de secretário da Fazenda em Santa Catarina, em virtude da deposição do governador Fúlvio Aducci. ${ }^{467}$

\footnotetext{
${ }^{465}$ VENÂNCIO FILHO, Alberto. Notícia histórica da OAB, op. cit., p. 77.

${ }^{466}$ CARVALHO NETO, Antônio Manuel de. In: ABREU, Alzira Alves de et alli (coord.), op. cit.

${ }^{467}$ COSTA, Artur Ferreira da. In: ABREU, Alzira Alves de et alli (coord.), op. cit.
} 
Havia, obviamente, aqueles conselheiros federais da $\mathrm{OAB}$ que, ao obterem seus diplomas, tinham se dedicado à advocacia, geralmente na cidade de sua família ou na capital do seu estado de origem. Nestes lugares podiam contar com as vantagens proporcionadas pelo prestígio social ou pelo poderio político de que gozavam suas famílias. Veja-se o caso de Cândido Luís Maria de Oliveira Neto, que fez parte da delegação do Distrito Federal entre 1949 e 1954. Nascido na cidade do Rio de Janeiro em 1902 e formado em 1925, descendia de uma família de juristas e políticos ilustres. Seu pai foi professor catedrático de Direito Judiciário Civil no Rio de Janeiro. Seu avô paterno, o conselheiro Cândido Luís Maria de Oliveira, foi deputado-geral entre 1878 e 1886, além de senador por Minas Gerais e ministro da Guerra (1884-1885) e da Justiça (1889); foi igualmente professor e diretor da Faculdade Livre de Direito do Rio de Janeiro. Ainda estudante de Direito, Cândido de Oliveira Neto passou a trabalhar no escritório de advocacia de sua família, estabelecido por seu avô e, posteriormente, mantido por seu pai. Ao se formar, assumiu este escritório ao lado de seu irmão Arnaldo Cândido de Oliveira. ${ }^{468}$ Com o decorrer dos anos, parte destes bacharéis mudava-se para a capital da República, em busca, possivelmente, de maior projeção profissional. O exercício da advocacia no Rio de Janeiro também foi o destino de magistrados aposentados noutros estados ou de bacharéis exilados da política, em virtude da Revolução de 1930 ou do golpe do Estado Novo.

Outra possibilidade profissional oferecida aos conselheiros federais era a ocupação de postos de direção ou assessoria em empresas privadas. Cícero Aranha, representou o seu estado natal, o Rio Grande do Norte, no Conselho Federal, em 1947 e 1948. Nascido em 1894 e formado pela Faculdade de Direito do Recife, Aranha foi, durante a Primeira República, prefeito de Macaíba $(\mathrm{RN})$ e secretário de Fazenda do Rio Grande do Norte, cargo do qual foi deposto pela Revolução de 1930. Em 1943, tornouse diretor do Banco Aliança, do Rio de Janeiro. ${ }^{469}$ Há ainda que se lembrar que o

\footnotetext{
${ }^{468}$ OLIVEIRA NETO, Cândido de. In: ABREU, Alzira Alves de et alli (coord.), op. cit.; CORTÉS, C. Homens e instituições no Rio. Rio de Janeiro: IBGE, 1957, p. 402.

${ }^{469}$ Quem é quem no Brasil. Biografias contemporâneas. São Paulo: Sociedade Brasileira de Expansão Comercial, 1951, p. 31; SILVA, Raimundo Nonato. Bacharéis de Olinda e Recife. Norte-riograndenses formados de 1832 a 1932. Rio de Janeiro: Pongetti, 1960, p. 305-306.
} 
presidente da OAB Raul Fernandes foi advogado das empresas da família Guinle por cerca de cinqüenta anos. ${ }^{470} \mathrm{E}$ há ainda o caso do bâtonnier Nehemias Gueiros, que, no início da década de 1960, advogava para grupos econômicos que faziam oposição a João Goulart, segundo o relato de Fernando Coelho. ${ }^{471}$

O magistério superior foi outro percurso profissional trilhado pelos conselheiros federais. Ao menos um terço dos conselheiros foi também professor de Faculdades de Direito. Professores das variadas especialidades do Direito, estes bacharéis dedicavamse, simultaneamente a outras atividades, como a advocacia. Observe-se, por exemplo, a trajetória de Eurico de Aguiar Sales, que representou no Conselho Federal da OAB o seu estado natal, o Espírito Santo, entre 1946 e 1949 e novamente em 1951. Assim que se formou na Faculdade de Direito do Rio de Janeiro, em 1931, Sales montou um escritório de advocacia em Vitória. Em 1935 ingressou no Banco de Crédito Agrícola do Espírito Santo como consultor jurídico e, no mesmo ano, tornou-se professor de Direito Comercial na Faculdade de Direito do Espírito Santo. Assim, já era professor universitário quando assumiu a Secretaria de Educação e Cultura do Espírito Santo, cargo que ocupou de 1937 a $1945 .^{472}$ Veja-se, igualmente, o caso de Demóstenes Madureira de Pinho, integrante das delegações da Bahia e do Distrito Federal no Conselho Federal entre 1950 e 1952. Pinho nasceu em 1911 e formou-se em 1932, em Salvador. Já era professor catedrático da Faculdade Nacional de Direito, no Rio de Janeiro, quando foi nomeado consultor jurídico do Ministério da Guerra, em $1947 .{ }^{473}$

Quase um terço dos conselheiros da OAB dedicava-se ou havia se dedicado ao jornalismo que, além de se constituir numa atividade profissional, era uma trincheira política na qual os bacharéis mantinham uma secular militância. No seu estudo sobre a Faculdade de Direito de São Paulo ao longo do século XIX, Sergio Adorno demonstra que o exercício do periodismo compensava a debilidade do ensino oferecido pela

\footnotetext{
${ }^{470}$ CARVALHO, Antônio Gontijo, op. cit., p. 59.

${ }^{471}$ COELHO, Fernando. A $O A B$ e o regime militar (1964-1986). Recife: OAB - Seção Pernambuco, 1996, p. 44.

${ }^{472}$ SALES, Eurico. In: ABREU, Alzira Alves de et alli (coord.), op. cit.

${ }^{473}$ COUTINHO, Afrânio, op. cit., p. 275.
} 
instituição na formação dos bacharéis. ${ }^{474}$ Como se vê, a tradição do periodismo manteve-se forte entre os bacharéis brasileiros na primeira metade do século XX, o que pode ser ilustrado pela trajetória de dois conselheiros federais da OAB. Nelson de Sousa Carneiro representou a Bahia no Conselho Federal em quase todo o período democrático. Nascido em 1910 e formado pela Faculdade de Direito da Bahia, assumiria, em 1947, uma cadeira na Câmara dos Deputados pela UDN. A partir de 1929, trabalhou como secretário de $O$ Jornal, periódico ligado à Aliança Liberal. ${ }^{475}$ Heráclito Fontoura Sobral Pinto integrou o Conselho Federal da OAB como representante do Distrito Federal, em 1945, e de Minas Gerais, em anos alternados entre 1947 e 1957. Nascido em 1893, Sobral Pinto trabalhou na Procuradoria Criminal da República na década de 1920. Por volta de 1928, vinculou-se ao Centro Dom Vital, entidade ligada à Igreja Católica. Neste ano, passou a colaborar com o jornal A Ordem, publicado por esta entidade religiosa. Pouco depois da Revolução de 1930, por meio do periódico, passou a dirigir ataques ao governo provisório de Getúlio Vargas. Em 1932, teve sua prisão decretada em virtude de sua oposição ao governo federal. Durante o Estado Novo, foi proibido de publicar artigos na imprensa. ${ }^{476}$

A produção intelectual era profícua entre os conselheiros da OAB. Ao menos um terço deles era autor de livros. Estas obras abordavam não apenas temas jurídicos, mas também se debruçavam sobre política, literatura e história. A produção intelectual nestas áreas era uma tradição bacharelesca que remontava ao Império, quando as

\footnotetext{
474 "A propósito, o estudo da vida extracurricular revelou a existência de uma infinidade de periódicos, na maior parte porta-vozes de institutos e associações científicos, filosóficos, literários etc., comprometidos com distintas orientações político-partidárias e que expressam algo inusitado: o periodismo proporcionou o espaço necessário à formação profissional do bacharel e, nessa condição, fez as 'honras das casa' ao substituir as salas de aula nas suas tradicionais atribuições de ensinar. De fato, foi através do jornalismo que o acadêmico/bacharel aprendeu a complexa arte da política. O periodismo representou a ante-sala dos gabinetes executivos, da tribuna parlamentar, dos tribunais judiciários, além de haver promovido a institucionalização da estética literária. Foi também responsável pelo aprendizado da demagogia. Proporcionou ao bacharel a oportunidade de burilar a linguagem falada e escrita, instrumentos fundamentais da atividade politica." ADORNO, Sergio, op. cit., p. 238. Em Um estadista do Império, Joaquim Nabuco escreveu: "Em Olinda (...) os acadêmicos exercitavam-se para a política em folhas volantes que fundavam.” NABUCO, Joaquim. Um estadista do Império. São Paulo: Instituto Progresso Editorial, 1949, v.1, p. 19.

${ }^{475}$ CARNEIRO, Nelson. In: ABREU, Alzira Alves de et alli (coord.), op. cit.

${ }^{476}$ COUTINHO, Amélia. PINTO, Sobral. In: ABREU, Alzira Alves de et alli (coord.), op. cit.
} 
Faculdades de Direito concentravam a produção cultural do país. ${ }^{477}$ A dedicação dos conselheiros federais a outras disciplinas além do Direito espelha-se no dado de que ao menos $14 \%$ deles participavam de sociedades literárias, históricas ou geográficas. Era o caso de Afonso Pena Júnior. Filho de um presidente da República que governou o país na primeira década do século XX, representou o Distrito Federal no Conselho Federal no ano de 1947. Nascido em 1879 e bacharelado pela Faculdade de Direito de Belo Horizonte em 1902, cumpriu uma importante carreira política na Primeira República, chegando a ministro da Justiça entre 1925 e 1926. Dirigente do Partido Republicano Mineiro (PRM), apoiou a Revolução de 1930. Em 1943, assinou o Manifesto dos Mineiros, motivo pelo qual foi demitido do cargo de advogado do Banco Hipotecário e Agrícola de Minas Gerais. Paralelamente às atividades políticas, porém, dedicou-se à produção intelectual. Publicou livros como A educação pelo escotismo (1935), Crítica de atribuição de um manuscrito da Biblioteca da Ajuda (1943), e A arte de furtar e o seu autor (1946). Em 1947, foi eleito membro da Academia Brasileira de Letras (ABL). ${ }^{478}$ Na segunda metade da década de 1940, outro imortal da ABL fez parte do Conselho Federal. Nascido em 1892 e formado pela Faculdade Livre de Ciências Jurídicas e Sociais do Rio de Janeiro, Rodrigo Otávio de Langgaard Meneses Filho representou o Distrito Federal no Conselho Federal em 1948. Provinha de uma família de sólida tradição jurídica e política. Seu avô paterno, Rodrigo Otávio de Oliveira Meneses, foi presidente da província do Paraná. Seu avô materno, Manuel Veloso Paranhos Pederneiras, foi, durante muitos anos, um dos principais redatores do Jornal do Comércio. Já seu pai foi consultor-geral da República entre 1911 e 1929 e ministro

477 "Até meados da Primeira República, a Faculdade de Direito era a instância suprema em termos de produção ideológica, concentrando inúmeras funções políticas e culturais. No interior do sistema de ensino destinado à reprodução da classe dominante, ocupava posição hegemônica por força de sua contribuição à integração intelectual, política e moral dos herdeiros de uma classe dispersa de proprietários rurais aos quais conferia uma legitimidade escolar. A Faculdade de Direito atuava ainda como intermediária na importação e difusão da produção intelectual europeia, centralizando o movimento editorial de revistas e jornais literários; fazia as vezes de celeiro que supria a demanda por indivíduos treinados e aptos a assumir os postos parlamentares e os cargos de cúpula dos órgãos administrativos, além de contribuir com o pessoal especializado para as demais burocracias, o magistério superior e a magistratura. " MICELI, Sergio. Intelectuais e classe dirigente no Brasil, op. cit., p. 115.

${ }^{478}$ FARIA, Helena. PENA JÚNIOR, Afonso. In: ABREU, Alzira Alves de et alli (coord.), op. cit.; MICELI, Sergio. Carne e osso, op. cit., p. 580; CF-OAB, Ata de sessão do Conselho Federal, 29/7/1947. 
do STF de 1929 a 1934, além de ter dirigido o IAB na década de 1910. Em 1945, Rodrigo Otávio Filho ingressou na $\mathrm{ABL}$, da qual seu pai havia sido fundador e membro. $^{479}$

\section{c.) Associativismo}

Há que se destacar a tradição associativa dos bacharéis da $\mathrm{OAB}^{480}$. Muitos deles pertenciam a outras entidades de advogados ou de Direito, além de participarem de sociedades literárias, históricas ou geográficas. Um terço deles foi, durante o Primeiro governo Vargas, presidente ou integrante dos conselhos estaduais da OAB, conselheiro federal da Ordem dos Advogados ou, mesmo, presidente do IAB. Ou seja, vários membros do Conselho Federal da OAB no período democrático haviam já integrado o órgão na década de 1930 ou na primeira metade da década seguinte. Eram os casos de Haroldo Valadão (conselheiro federal em 1933), Demóstenes Madureira de Pinho (1942), Nelson Carneiro (1942), Artur da Rocha Ribeiro (1934), Ubaldo Ramalhete, Jair Tovar (a partir de 1934), Djalma Tavares da Cunha Melo, Aristeu Borges (desde 1939), Odilon Andrade e Temístocles Marcondes Ferreira. Além deles, Pinto Lima já exercera a presidência interina do órgão em 1944, substituindo a Melo Viana, e Atílio Vivacqua fora secretário-geral da OAB de 1933 a $1944 .^{481}$

Entre os conselheiros federais que se tornaram presidentes das seccionais da OAB de seus estados ou exerceram a presidência estadual da Ordem para depois se tornarem conselheiros federais no período estudado pode-se citar: Gilberto Valente (presidente da OAB-BA, 1951), Afrânio Lages (presidente da OAB-AL, 1951-1961), Paulo Fleury (presidente da OAB-GO), Milton Campos (presidente da OAB-MG),

\footnotetext{
${ }^{479}$ CORTÉS, C., op. cit., p. 369-370; BONELLI, Maria da Glória, op. cit., p. 80; PANTOJA, Sílvia. OTÁVIO, Rodrigo. In: ABREU, Alzira Alves de et alli (coord.), op. cit.

${ }^{480} \mathrm{O}$ associativismo distinguirá a elite das profissões liberais desde o Império, como demonstra Edmundo Coelho em As profissões liberais. Medicina, Engenharia e advocacia no Rio de Janeiro: 1822-1930, op. cit., p. 95-96.

${ }^{481}$ BASTOS, Aurélio Wander, op. cit., p. 150, 163 e 172; Boletim da Ordem dos Advogados do Brasil, Rio de Janeiro, volume 1, número 3, dezembro 1957; CF-OAB, Atas de sessão do Conselho Federal de 3/6/1947, 17/6/1947, 20/06/1950 e 4/9/1951; CORTÉS, C. op. cit., p. 411-412; VENÂNCIO FILHO, Alberto. Notícia histórica da $O A B$, op. cit., p. 77 e 85; OLIVEIRA, João Gualberto de, op. cit., p. 356$358,361-362$.
} 
Fernando Nóbrega (presidente da OAB-PB, 1944), Alberto Francisco Torres (presidente da OAB-RJ, 1951-1953), Afonso Wanderley Júnior (presidente da OAB-SC), Antônio Manuel de Carvalho Neto (presidente da OAB-SE), Alci Amorim da Cruz (presidente da OAB-RJ, 1963), Jorge Lafayette Pinto Guimarães (presidente da OAB-GB, 1963), Hebel Quintella (presidente da OAB-AL, 1961), Davi Alves de Melo (presidente da OAB-AM, 1961), Dídimo de Morais (presidente da OAB-ES, 1961), Raul da Cunha Ribeiro (presidente da OAB-GB, 1961), Otávio Mendonça (presidente da OAB-PA, 1961), Osvaldo Vergara (presidente da OAB-RS, 1961) e João Batista Bonassis (presidente da OAB-SC, 1961). ${ }^{482}$

Destaque-se a alta incidência de bacharéis que foram, entre 1945 e 1964, conselheiros federais e presidentes dos conselhos seccionais da OAB do Distrito Federal (Rio de Janeiro) e da Guanabara. Neste período, com duas exceções, os presidentes da seção do estado do Rio de Janeiro, também, integraram o Conselho Federal da Ordem dos Advogados. No mesmo período, com uma única exceção, os presidentes da seção do Distrito Federal (Rio de Janeiro) foram, igualmente, conselheiros federais da OAB. Finalmente, todos os quatro presidentes da seccional da Guanabara da OAB (fundada em 1961) no período democrático compuseram o Conselho Federal. A influência da seção do Distrito Federal no Conselho Federal revela-se, entre outros, pelo fato de que três de seus ex-presidentes, Pinto Lima, Alcino Salazar e Prado Kelly presidiram, também, o Conselho Federal no período estudado. ${ }^{483}$

Vários conselheiros federais ou presidentes da Ordem dos Advogados tornaramse presidentes do IAB ou vice-versa. Levi Carneiro, que presidiu a OAB de 1933 a 1938, fora presidente do IAB entre 1928 e 1931. Augusto Pinto Lima, eleito presidente do Conselho Federal em 1948, dirigira o IAB nos períodos 1933-1935 e 1931-1941. Haroldo Teixeira Valadão, presidente da OAB em 1950-1952, fora presidente do IAB em 1944-1946. Miguel Seabra Fagundes, presidente da OAB entre 1954 e 1956, comandaria o IAB no período 1970-1972. Os presidentes do IAB Targino Ribeiro

\footnotetext{
${ }^{482}$ ABREU, Alzira Alves de et alli. (coord.), op. cit.; CF-OAB, Ata de sessão do Conselho Federal de 24/4/1951; Boletim da Ordem dos Advogados do Brasil, Rio de Janeiro, ano 28, número 28, 1962.

${ }^{483}$ A lista de presidentes das seccionais da OAB do Distrito Federal, Rio de Janeiro e Guanabara foi

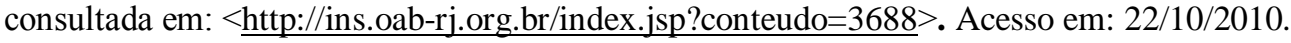


(1946-1948), Arnoldo Medeiros da Fonseca (1948-1950), Justo Rangel Mendes de Morais (1950-1952), Osvaldo Murgel de Rezende (1952-1954), Jorge Dyott Fontenelle (1954-1956), Oto de Andrade Gil (1958-1960) e João de Oliveira Filho (1961-1962) atuaram como conselheiros federais da $\mathrm{OAB}$ no período democrático. Ademais, Heráclito Sobral Pinto, conselheiro federal desde 1945, seria eleito presidente do IAB para o biênio 1964-1965, e Teófilo de Azeredo Santos, membro da delegação mineira no Conselho Federal em 1963, presidiria o IAB entre 1972 e $1974 .^{484}$

Os bacharéis que integraram o Conselho Federal frequentaram e dirigiram outras associações de classe, como o Clube dos Advogados. O bâtonnier Atílio Vivacqua, por exemplo, dirigiu a entidade, que teve como vice-presidente na primeira metade da década de 1940, Osvaldo Trigueiro, secretário-geral da OAB entre 1944 e $1946 .{ }^{485}$

Em seu conjunto, estas observações demonstram que a direção das duas principais entidades de advogados em âmbito nacional (a OAB e o IAB), assim como as seções estaduais da Ordem dos Advogados, estiveram, durante o período democrático, sob o controle de uma elite de bacharéis que se fazia presente, inclusive, em outras associações de classe.

\section{d.) Direção do Estado e participação política}

Uma parte dos conselheiros federais ingressou na vida política ainda na Primeira República, mais comumente exercendo mandatos no Legislativo (nas esferas municipal, estadual ou federal) ou ocupando cargos nos governos dos estados e municípios e, menos, no governo federal. Evidentemente estes conselheiros desempenhavam, em paralelo, atividades propriamente partidárias, como chefes locais de seus partidos ou membros de seus diretórios. Além dos postos no Legislativo e no Executivo e das carreiras jurídicas, outro acesso ao Estado durante a Primeira República, embora menos

\footnotetext{
${ }^{484}$ A lista dos presidentes do Instituto dos Advogados Brasileiros (IAB) foi consultada em: BONELLI, Maria da Glória, op. cit., p. 80-81; OLIVEIRA, João Gualberto de, p. 467; $<$ http://www.iabnacional.org.br/rubrique.php3?id_rubrique $=8>$. Acesso em: 22/10/2010. As listas disponíveis em Maria da Gloria Bonelli e no site do IAB são praticamente idênticas, porém Gualberto de Oliveira acrescenta alguns nomes à lista. Tomou-se como fonte as duas primeiras listas.

${ }^{485}$ VIVACQUA, Atílio. In: ABREU, Alzira Alves de et alli (coord.), op. cit.; TRIGUEIRO, Osvaldo. In: ABREU, Alzira Alves de et alli (coord.), op. cit.
} 
frequentemente usado pelos conselheiros, foi o exercício de cargos subalternos na burocracia estatal. Este era, possivelmente, o meio colocado ao alcance de bacharéis pobres ou carentes de padrinhos em condições de os alçarem a bons postos de trabalho.

É interessante notar uma ligeira elevação na frequência de militância partidária dos conselheiros federais na primeira metade do governo Vargas - enquanto foi permitido o funcionamento dos partidos políticos, entre 1930 e 1937 -em relação à verificada durante a Primeira República. Observe-se que, em grande medida, trata-se dos mesmos homens, ou seja, bacharéis que se iniciaram na militância política ainda na Primeira República e continuaram na vida partidária depois da Revolução de 1930 e, não raro, após a queda do Estado Novo. Este dado mostra um traço de permanência no interior da elite política na passagem da Primeira República para o período Vargas, malgrado a ruptura representada pela Revolução de 1930. Mas também é verdade que um grupo significativo de conselheiros federais ingressou na vida político-partidária apenas na década de 1930. A taxa de militância partidária dos integrantes do Conselho Federal praticamente dobrou no pós-1945 em relação à Primeira República e ao primeiro governo Vargas.

Durante a Primeira República, os conselheiros da OAB militaram tanto nos partidos oligárquicos que dominavam o poder estadual quanto nas agremiações oligárquicas dissidentes. Para exemplificar o primeiro caso, cite-se José Augusto Bezerra de Medeiros, nascido em 1884 e representante do Rio Grande do Norte no Conselho Federal da OAB entre 1945 e 1947 e entre 1963 e 1964. Proveniente de uma família ilustre, uma das que dominavam a política potiguar desde o fim do Império, seu avô materno, José Bernardo de Medeiros, foi chefe político do Seridó, deputado estadual por vários mandatos e senador no Rio Grande do Norte. Seu avô paterno, Silvino Bezerra de Araújo Galvão, foi deputado estadual no Rio Grande do Norte, líder do Partido Republicano Federal e vice-governador do estado nos anos iniciais da República. Seu pai, Manuel Augusto Bezerra de Araújo, foi deputado estadual. Seu tio, Juvenal Lamartine de Faria, foi senador e presidente do Rio Grande do Norte entre 1928 e 1930. José Augusto formou-se em 1905 pela Faculdade de Direito do Recife, abrindo, em seguida, um escritório de advocacia em Natal, onde passou a lecionar História e 
Geografia no Ateneu Norte Riograndense. Pouco depois, assumiu funções públicas importantes como diretor da instrução pública estadual e chefe de polícia interino. Logo seria eleito deputado estadual e, anos depois, deputado federal. Entre 1924 e 1928, foi presidente do Rio Grande do Norte, eleito com apoio do presidente Artur Bernardes. Findo o seu mandato, elegeu-se senador pelo Rio Grande do Norte. Com a Revolução de 1930, passou a ser hostilizado pelo novo regime como um dos "carcomidos" da Primeira República. Sua atuação pública foi alvo de investigação na justiça revolucionária. Exilado da política, voltou a advogar, desta vez no Rio de Janeiro. Retomando as atividades políticas, conspirou, no Nordeste, pela Revolução Constitucionalista. No ano seguinte, fundou o Partido Popular (PP), de oposição ao interventor federal Bertino Dutra, pelo qual voltou a ocupar uma cadeira no parlamento como deputado federal, em meados da década de 1930. Fundador da UDN, José Augusto tornou-se um nome importante dentro da sigla. No período em que era conselheiro da $\mathrm{OAB}$ exerceu concomitantemente mandato de deputado federal pelo seu estado natal. ${ }^{486}$

Outro conselheiro federal vinculado à situação estadual na Primeira República era José Martins Rodrigues, representante do Ceará no Conselho Federal de 1949 a 1955. Nascido em 1901 e formado pela Faculdade de Direito de Fortaleza, era filho da aristocracia rural cearense. Em 1925, pouco depois de formado, elegeu-se deputado estadual, assumindo a liderança do grupo político que sustentava o governador José Carlos Matos Peixoto. Nesta condição, destacou-se no combate aos seguidores do Padre Cícero, que haviam organizado um núcleo político-religioso em Juazeiro. Com a Revolução de 1930, foi apeado do poder. ${ }^{487}$

Entre os conselheiros que militaram em dissidências oligárquicas na Primeira República pode-se mencionar Aureliano Leite e Leopoldo Tavares da Cunha Melo. Aureliano Leite, conselheiro federal por São Paulo entre 1948 e 1952, fora um dos fundadores, na década de 1920, do Partido Democrático (PD), dissidência oligárquica

\footnotetext{
${ }^{486}$ MALIN, Mauro. AUGUSTO, José. In: ABREU, Alzira Alves de et alli (coord.), op. cit.

${ }^{487}$ RAMOS, Plínio de Abreu. RODRIGUES, Martins. In: ABREU, Alzira Alves de et alli (coord.), op. cit.
} 
paulista que se opunha ao Partido Republicano Paulista (PRP). Nascido em 1886 e formado pela Faculdade de Direito de São Paulo, Leite apoiou a Revolução de 1930. Em 1932, entretanto, rompeu com o governo federal e tornou-se um ativo articulador da Revolução Constitucionalista. Derrotado o movimento, exilou-se na Europa. De volta ao Brasil, elegeu-se deputado federal pelo Partido Constitucionalista, fundado pelo interventor federal de São Paulo, Armando Sales de Oliveira. Fez oposição ao Estado Novo e por isso sofreu várias prisões. Com a redemocratização, filiou-se à UDN, legenda pela qual foi eleito deputado constituinte em 1945. ${ }^{488}$ Já Leopoldo Tavares da Cunha Melo foi conselheiro federal pelo Amazonas em 1946 e 1950. Nascido em 1891 e diplomado pela Faculdade de Direito do Recife, era filho do desembargador amazonense José Tavares da Cunha Melo. Na década de 1920, Leopoldo Cunha Melo combatera o governador do Amazonas, César do Rego Monteiro, representante da oligarquia dominante na política do estado. A partir de 1927, já radicado no Rio de Janeiro, assumiu a defesa de vários oficiais envolvidos no levante tenentista amazonense de 1924. Pouco depois, seria um dos fundadores do Partido Socialista do Amazonas, que apoiava a coalizão de forças lideradas pelos tenentes destinada a dar apoio, no estado, ao governo provisório de Vargas. ${ }^{489}$

Considerando os dados disponíveis acerca das posições políticas adotadas pelos conselheiros federais em relação à situação nacional ao longo da década de 1930, verifica-se uma nítida proximidade destes em relação à Revolução de 1930 e à primeira fase do primeiro governo Vargas (1930-1937). A maioria esmagadora dos conselheiros apoiou o movimento que derrubou a Primeira República, assim como sustentou, ao menos nos seus primeiros anos, o governo que se instalou a partir de então. Esta conclusão não contradiz aquela outra que mostra um equilíbrio na presença dos conselheiros vinculados a grupos oligárquicos estaduais dominantes e a grupos oligárquicos minoritários. Como se sabe, se é verdade que a Aliança Liberal era composta por dissidências estaduais oligárquicas, também encontrou respaldo em forças

\footnotetext{
${ }^{488}$ MAYER, Jorge Miguel. LEITE, Aureliano. In: ABREU, Alzira Alves de et alli (coord.), op. cit. ${ }^{489}$ KELLER, Vilma. MELO, Leopoldo Tavares da Cunha. In: ABREU, Alzira Alves de et alli (coord.), op. cit.
} 
hegemônicas nos seus estados - talvez os casos mais expressivos tenham sido o do Partido Republicano Mineiro (PRM) e do Partido Republicano Rio-Grandense (PRR).

Entre os conselheiros federais, havia vários aliancistas e entusiastas da Revolução de 1930 que, ao longo da década de 1930, afastaram-se ou romperam com Vargas. As trajetórias dos conselheiros federais Dâmaso Rocha e Daniel de Carvalho são ilustrativas a este respeito. Dâmaso Rocha integrou a delegação do Rio Grande do Sul no Conselho Federal em 1950. Filho do dentista e professor Olímpio Rocha, nasceu em 1909 e formou-se pela Faculdade de Direito de Porto Alegre. Promotor de justiça nesta cidade na década de 1930, apoiou o movimento revolucionário liderado por Vargas, mas passou à oposição com o advento do Estado Novo. No entanto, ao contrário da grande maioria dos seus contemporâneos que cumpriram a mesma trajetória, não se filiou, em 1945, à UDN, mas ao PSD, pelo qual se elegeu deputado constituinte $^{490}$. Daniel Serapião de Carvalho representou o Distrito Federal no Conselho Federal em 1945 e entre 1957 e 1958. Nascido em Minas Gerais em 1887, era filho do magistrado Antônio Serapião de Carvalho. Como membro do Partido Republicano Mineiro (PRM), Daniel de Carvalho participou da campanha da Aliança Liberal e, posteriormente, rumou para a Europa com o objetivo de angariar apoio para a conspiração que se tramava contra o presidente Washington Luís. Em 1943, foi demitido do cargo de diretor-secretário da Companhia Siderúrgica Nacional por ter assinado o Manifesto dos Mineiros. ${ }^{491}$

A presença de parlamentares ou ex-parlamentares no Conselho Federal foi marcante no período estudado. Pelo menos 29 conselheiros federais tinham exercido mandatos junto aos legislativos municipais, estaduais ou federal na Primeira República. Ao menos 39 deles o fizeram entre 1930 e 1937. No período democrático, ao menos 63 integrantes do Conselho Federal assumiram mandatos nas assembléias estaduais ou no Congresso Nacional. Observe-se que $40 \%$ dos conselheiros federais já haviam exercido ou estavam exercendo mandatos parlamentares ao ingressarem no Conselho Federal da

\footnotetext{
${ }^{490}$ ROCHA, Dâmaso. In: ABREU, Alzira Alves de et alli (coord.), op. cit.

491 PANTOJA, Sílvia. CARVALHO, Daniel de. In: ABREU, Alzira Alves de et alli (coord.), op. cit. MICELI, Sergio. Carne e osso da elite política brasileira pós-1930, op. cit., p. 586-587.
} 
OAB. Alberto Venâncio Filho observa a elevada presença de parlamentares no Conselho Federal desde o início dos seus trabalhos até 1960, quando a capital da República transferiu-se para Brasília, mas a sede da OAB permaneceu no Rio de Janeiro (onde ficou até meados da década de 1980). Segundo este autor, 66\% dos bacharéis que compunham o Conselho Federal da OAB em 1934 exerciam simultaneamente mandatos parlamentares, incluindo o presidente da entidade, Levi Carneiro, que era deputado constituinte. Entre os conselheiros de 1937, o percentual de parlamentares era de $41 \% .^{492}$

Além da experiência legislativa, muitos bacharéis que exerceram mandatos no Conselho Federal da OAB entre 1945 e 1964, haviam desempenhado funções no Executivo. Na Primeira República, 4\% dos conselheiros ocuparam cargos no executivo federal e $12 \%$ nos executivos estaduais ou municipais. Entre 1930 e 1937, os percentuais são aproximadamente $5 \%$ e $12 \%$, respectivamente. No Estado Novo, cerca de $7 \%$ dos conselheiros ocuparam postos no executivo federal e quase $5 \%$ nos executivos estaduais. Finalmente, para o período democrático, os percentuais aproximados são, respectivamente, $14 \%$ e $8 \%$ (Tabela 6).

\section{Tabela 6: Exercício de cargos no Executivo pelos conselheiros federais da OAB no} período democrático

\begin{tabular}{ccc}
\hline Período & $\begin{array}{c}\text { Participação no } \\
\text { Executivo federal }\end{array}$ & $\begin{array}{c}\text { Participação nos Executivos } \\
\text { estaduais e municipais }\end{array}$ \\
\hline Primeira & $4 \%$ & $12 \%$ \\
República & & $12 \%$ \\
$\mathbf{1 9 3 0 - 1 9 3 7}$ & $5 \%$ & $5 \%$ \\
Estado & $7 \%$ & \\
Novo & & \\
\hline
\end{tabular}

${ }^{492}$ VENÂNCIO FILHO, Alberto. Notícia histórica da OAB, op. cit., p. 47. Em depoimento concedido a Alberto Venâncio Filho em 1981, Alberto Barreto de Mello, apontou que na segunda metade da década de 1940, o Conselho Federal era, em parte, um "conselho de parlamentares". VENÂNCIO FILHO, Alberto. Notícia histórica da $O A B$, op. cit., p. 77. 


\begin{tabular}{llc}
\hline $\mathbf{1 9 4 5 - 1 9 6 4}$ & $14 \%$ & $8 \%$ \\
\hline
\end{tabular}

Fontes: Atas do Conselho Federal da OAB (1945-1964) e dicionários biográficos.

Quase $40 \%$ dos conselheiros federais já havia desempenhado funções de confiança no Poder Executivo (em geral, em altas posições, como ministros e secretários) nos níveis municipal, estadual e federal. Finalmente, dentre os 189 conselheiros dos quais se dispõe de informações biográficas, pode-se afirmar que 96 exerceram mandatos parlamentares ou funções no Executivo nos três níveis da federação, entre a Primeira República e o período democrático, o que representa cerca de $50 \%$. Como se vê, o percentual não é muito maior que os percentuais de participação no Parlamento ou no Executivo tomados individualmente. Os dados demonstram que a maioria destes conselheiros federais atuou nos dois poderes, o que reforça a percepção de que o Conselho Federal tinha entre seus membros muitos "homens públicos".

\section{e.) Vínculos partidários}

$\mathrm{O}$ retrato da elite política brasileira no período democrático feito por Sergio Miceli oferece importantes elementos para o estudo do perfil dos conselheiros federais. A razão fundamental é que a elite política esquadrinhada por Miceli confundia-se parcialmente com a elite dos juristas-políticos da Ordem dos Advogados (um grupo pertencente, simultaneamente, à elite política e à elite dos advogados). $\mathrm{O}$ autor examina as origens sociais e as trajetórias políticas e profissionais dos pessedistas, de um lado, e dos udenistas, de outro. Para resumir as conclusões do autor, pode-se dizer que os udenistas se fizeram à sombra do prestígio familiar e do setor privado, ao passo que os pessedistas deveram o seu sucesso ao regime de 1930. Como se verá, os juristaspolíticos do Conselho Federal da OAB estiveram presentes tanto na UDN como no PSD.

Com relação aos udenistas, três características marcantes da sua trajetória merecem destaque. Em primeiro lugar, a antiguidade da presença de suas famílias no comando do Estado e das agremiações políticas. Em comparação com a bancada do PSD na Constituinte de 1946, a da UDN contava com mais parlamentares que haviam 
exercido mandatos no Legislativo antes de 1945 ou mesmo antes de 1930. Infere-se daí a maior proximidade dos udenistas com as oligarquias estaduais dominantes na Primeira República - derrubadas em 1930 ou aliadas da Revolução e que procuraram reconquistar ou afirmar suas posições de comando nas eleições para as Constituintes estaduais e federal em meados da década de 1930. Muitos udenistas iniciaram sua carreira como advogados em cidades do interior, em geral em locais dominados politicamente por suas famílias ou em redutos de chefes políticos aos quais estavam vinculados. Aqueles que possuíam melhores relações políticas começaram sua carreira em posições de prestígio, como professores universitários ou promotores. ${ }^{493}$

Em segundo lugar, a posição privilegiada dos udenistas nas profissões liberais, tanto no aparato de Estado quanto no setor privado (como consultores ou assessores jurídicos, por exemplo). ${ }^{494}$ Eles pertenciam a famílias tradicionais nas profissões liberais, tendo ascendentes que haviam sido ministros do STF e de outros tribunais superiores, catedráticos e reitores de universidades e autores reconhecidos. Por isso, contavam com acesso privilegiado aos postos de cúpula das profissões liberais. Entretanto, para conservar sua preeminência nas profissões liberais, as famílias dos futuros udenistas precisaram oferecer-lhes a melhor formação escolar possível. Os udenistas estudaram nas mais prestigiosas escolas de seus estados e cursaram as Faculdades de Direito de Minas Gerais, Bahia e Rio de Janeiro. Assim, observa Miceli, não tiveram de se deslocar para São Paulo para obterem o diploma de bacharel e

\footnotetext{
${ }^{493}$ MICELI, Sergio. Carne e osso da elite política brasileira pós-1930, op. cit., p. 564, 584-588.

${ }^{494}$ Para Miceli, a forte presença udenista na cúpula das profissões liberais atraía para o partido o apoio dos setores sociais que possuíam curso superior e se dedicavam à ascensão social e profissional: " $a U D N$ investiu a fundo na incorporação de profissionais liberais, professores, magistrados e intelectuais de renome, com trânsito em seus campos de atividade, dispondo de posições de mando em entidades culturais e corporativas, e em condições de atrair o voto daqueles setores sociais beneficiados pela expansão recente do ensino superior, das instituições culturais e do sem-número de aparelhos públicos e privados nas áreas de educação e cultura, processo que estava na raiz da ampliação de postos no mercado de trabalho cativo dos detentores de diplomas superiores (...) o perfil programático udenista encampou as demandas daqueles setores sociais urbanos e escolarizados que estavam empenhados em esgarçar ao máximo suas oportunidades de melhoria social e profissional." MICELI, Sergio. Carne e osso da elite política brasileira pós-1930, op. cit., p. 568. Maria Victoria Benevides reconhece que a UDN dirigia um discurso específico às classes médias. No entanto, afirma esta autora, a UDN, em termos de defesa de interesses econômicos, comprometeu-se com os grandes proprietários rurais e a burguesia industrial associada ao capital estrangeiro. BENEVIDES, Maria Victoria de Mesquita, op. cit., p. 209218.
} 
também não viveram as dificuldades por que passaram os bacharéis formados, na década de 1920, nas recém-abertas faculdades livres. Apesar de terem se formado nesta época, marcada pela concorrência profissional e saturação do mercado de bacharéis, não tiveram dificuldades para ascender a posições políticas e profissionais de proa, que lhes estavam reservadas por "direito natural", isto é, em decorrência do prestígio e poder de suas famílias na cúpula das profissões liberais. ${ }^{495}$

Em terceiro lugar, os vínculos com o capital financeiro. Revolucionários em 1930, os futuros udenistas, ao se virem, ao longo do governo Vargas, preteridos ou mesmo expurgados da vida política, abrigaram-se na cúpula das profissões liberais (por exemplo, como professores de faculdades de Direito) ou em bancos, empresas de seguros e no setor imobiliário, como acionistas, diretores ou assessores. ${ }^{496}$ Os futuros udenistas estavam ligados ao capital financeiro por laços de amizade, parentesco e compadrio. Ademais, compartilhavam a ideologia liberal com os dirigentes e proprietários do setor financeiro. ${ }^{497} \mathrm{~A}$ acolhida encontrada no setor financeiro lhes proporcionou autonomia material e política em relação ao Estado - o que se reforçava pela posição destacada nas profissões liberais. Mas, em contrapartida, subordinou a atuação dos udenistas aos interesses políticos desta fração burguesa. ${ }^{498}$

Ao contrário dos udenistas, os futuros pessedistas não carregavam tradição familiar no exercício das profissões liberais, assim como não faziam parte da alta hierarquia profissional. Socialmente, ligavam-se a ramos oligárquicos subalternos. $\mathrm{O}$ governo Vargas ofereceria a estes bacharéis a oportunidade de ascensão social, política e profissional, por meio do exercício de altos cargos públicos. Assim, os futuros pessedistas tornar-se-iam grandes defensores da ampliação da área de atuação estatal

\footnotetext{
${ }^{495}$ MICELI, Sergio. Carne e osso da elite política brasileira pós-1930, op. cit., p. 584-588.

${ }^{496}$ Ibidem, p. 582-583.

${ }^{497}$ Ibidem, p. 591.

498 "Essa relativa autonomia social do núcleo de organizadores da UDN perante o setor público, que se reforça tanto mais pela posição vantajosa que seus integrantes ocupam na hierarquia das profissões liberais, tinha como contrapartida a sujeição às diretrizes políticas do setor privado e, por isso mesmo, restringiu drasticamente as alternativas viáveis de aliança política quer no interior da classe dirigente quer junto aos grupos sociais subalternos recém-incorporados à arena política." MICELI, Sergio. Carne e osso da elite política brasileira pós-1930, op. cit., p. 591.
} 
empreendida pelo regime de 1930, da qual se sabiam beneficiários - uma vez que seu poder advinha do exercício de funções governamentais. ${ }^{499}$

Basicamente, os integrantes da elite pessedista, sobretudo os bacharéis, devem seu sucesso profissional e político à fidelidade ao governo Vargas e às alianças com forças políticas estaduais, das quais faziam parte ou a elas se associavam pelo casamento). Não foram raros os casos em que as alianças com oligarquias estaduais mostraram-se mais decisivas que a subordinação aos desígnios do poder central. Os laços que os atavam às elites estaduais possibilitavam que os futuros pessedistas exercessem (provavelmente no início da carreira) cargos em nível municipal, como vereadores, prefeitos e chefes de partidos políticos. A chefia pessedista iniciou a carreira em cargos relativamente modestos no sistema judiciário ou de saúde, para em seguida serem alçados a postos mais importantes nestas esferas: "curadores, procuradores, diretores de hospitais, de corporações locais". Depois, receberam cargos propriamente políticos, vinculados ao Poder Executivo. Nesta fase de sua trajetória profissional, seguiram para a área de segurança (na qual se iniciaram como funcionários ou delegados de polícia e prosperaram para chefes de polícia ou secretários de Segurança Pública ou do Interior) ou para outras áreas, como educação, saúde, obras públicas e justiça, nas quais alguns chegaram a secretários estaduais. ${ }^{500}$

Ao menos $40 \%$ dos membros do Conselho Federal eram filiados a partidos políticos. Dentre os 80 conselheiros federais com filiação partidária conhecida, 33 pertenciam ao PSD e 29 à UDN. Em acréscimo, merece destaque o fato de que 44 conselheiros federais expressaram publicamente o seu apoio à candidatura de Eduardo Gomes, em 1945, apesar de, aparentemente, não terem se filiado à UDN. Este número de apoiadores da candidatura Eduardo Gomes maior que de filiados à UDN pode expressar uma adesão (ainda que não formalizada) superior a este partido que o número de 29 filiados sugere. Assim, se somarmos os 29 filiados à UDN aos outros 44 que possivelmente foram, ao menos, simpatizantes deste partido, temos 73 conselheiros federais no círculo de influência da UDN. Helio Saboya, membro do Conselho da OAB

\footnotetext{
${ }^{499}$ Ibidem, p. 583-584, 591.

${ }^{500}$ Ibidem, p. 573-574.
} 
do Rio de Janeiro desde 1978, confirma o peso da UDN no interior da elite dirigente da Ordem:

"Então, é curioso que alguns membros da Ordem, antigos Conselheiros, inclusive ex-Presidentes, critiquem o engajamento político-partidário da Ordem, que eu critico, também, mas, na época, que estes críticos foram Presidentes, eles estavam engajados. A UDN teve uma forte influência dentro da Ordem dos Advogados. Milton Campos, que foi uma pessoa de alta responsabilidade, tinha banca dentro do Conselho Seccional, dentro do Conselho Federal. Aliás, ele foi Presidente da Seccional de Minas Gerais. O Adauto Lúcio Cardoso, o Levi Carneiro e tantos outros (...) Então, eles criticam, não o engajamento políticopartidário, mas o engajamento dos outros (...), ${ }^{, 501}$

Vale a pena comparar os dois grupos partidários com maior presença no Conselho Federal. Em termos de origem social, os conselheiros udenistas eram mais bem nascidos do que os pessedistas. Quase metade dos udenistas pertencia a oligarquias estaduais ou a famílias com tradição na direção do Estado ou nas carreiras jurídicas. Um terço dos pessedistas tinha as mesmas origens. É preciso, contudo, ter um pouco de cautela em relação a estes dados, pois os repertórios biográficos são relativamente parcos deste tipo de informação. De toda maneira, estes dados confirmam a análise de Sergio Miceli a respeito da elite política do pós-1930.

No que diz respeito à trajetória política, os percentuais de exercício de cargos no Executivo ou de mandatos parlamentares dos dois grupos são próximos. Todavia, os conselheiros udenistas participaram de modo mais efetivo da Revolução de 1930, em que pese a oposição de alguns deles ao movimento. Da mesma forma, os dois grupos tiveram os mesmos índices de participação no Executivo entre 1930 e 1937. Neste período, contudo, os conselheiros udenistas destacaram-se por uma presença muito mais

501 LESSA, Renato; LINHARES, Leila, op. cit., p. 77-78. Alguns autores também destacam a proximidade do Conselho Federal da OAB com a UDN. Ver, por exemplo: COELHO, Fernando, op. cit., p. $44-45$. 
importante no parlamento, sobretudo no âmbito federal. No Estado Novo, os conselheiros udenistas foram expurgados ou se afastaram do Executivo, ao passo que os pessedistas mantiveram o nível de participação do período anterior, na faixa dos $30 \%$. Não são outros os motivos pelos quais se verifica o alto nível de engajamento à oposição ao Estado Novo no interior do grupo udenista e a quase inexistência de oposição ao regime de 1937-1945 entre os conselheiros ligados ao PSD.

A queda do Estado Novo permitiu uma participação equilibrada dos dois grupos nos executivos e legislativos estaduais. Porém, a predominância do grupo pessedista no âmbito federal era evidente: $91 \%$ dos conselheiros pessedistas exerceram mandatos no Congresso Nacional no período democrático. O percentual era de $65 \%$ entre os udenistas. Ademais, $21 \%$ dos pessedistas exerceram cargos no Executivo Federal entre 1945 e 1964 contra apenas 10\% dos udenistas. Estes exerceram altas funções públicas durante governos que contaram com o apoio da UDN. Assim, Raul Fernandes foi chanceler nos governos Dutra e Café Filho e Temístocles Brandão Cavalcanti foi procurador-geral da República nos mesmos governos. Já José Eduardo do Prado Kelly foi ministro da Justiça de Café Filho. Finalmente, os conselheiros udenistas tiveram uma participação muito mais intensa na condução do Estado na primeira fase da ditadura militar, no pré-AI-5, do que os conselheiros pessedistas - $41 \%$ dos conselheiros udenistas e 12\% dos conselheiros pessedistas exerceram cargos no Executivo ou mandatos pela ARENA ou, ainda, foram nomeados ministros do STF entre 1964 e 1968.

Nota-se uma presença maior de professores universitários, jornalistas e autores de livros no grupo udenista em comparação ao pessedista. E, igualmente, a participação bem mais intensa de conselheiros udenistas nos postos de direção das mais importantes entidades que congregavam advogados. Dentre os conselheiros udenistas, $59 \%$ já haviam integrado o Conselho Federal antes de 1945 ou tinham sido membros das direções estaduais da $\mathrm{OAB}$ ou da direção do IAB. Para os conselheiros pessedistas, o percentual era de $27 \%$. Os dados sugerem que os juristas-políticos da UDN exerciam a hegemonia nas principais entidades de advogados no país - fato que Sergio Miceli já apontara, no estudo acima referido. 
De maneira bem menos importante, outros partidos políticos contavam com filiados na cúpula da $\mathrm{OAB}$. Assim, cinco conselheiros federais eram filiados ao Partido Trabalhista Brasileiro (PTB), quatro ao Partido Social Progressista (PSP), três ao Partido Republicano (PR) e dois ao Partido Libertador (PL). O Partido Democrata Cristão (PDC), o Partido Socialista Brasileiro (PSB), o Partido Social Trabalhista (PST) e o Partido Popular Sindicalista (PPS) contavam, cada qual, com apenas um conselheiro federal. Constata-se, portanto, que os membros do Conselho Federal da Ordem dos Advogados agrupavam-se, em larga medida, em torno de organizações partidárias conservadoras. Mesmo tomando em conta os conselheiros federais vinculados ao $\mathrm{PTB}^{502}$ (que, diga-se de passagem, estava bastante sub-representado no Conselho Federal em relação à sua presença no Congresso Nacional), perceberemos que eram próximos a setores políticos dominantes nos seus estados de origem e que desempenharam importantes funções públicas nos seus estados ou na capital da República. A maioria havia se vinculado ao PSD, a UDN e ao PSP antes de se transferir para o PTB. Não há qualquer evidência de que tenham se comprometido de modo mais profundo com organizações de trabalhadores e interesses populares. Pode-se falar praticamente o mesmo em relação aos quatro conselheiros federais filiados ao PSP (Nicanor Faria e Silva, Elisabeto Barbosa de Carvalho, José Adriano Marrey Júnior e Teotônio Maurício Monteiro de Barros Filho).

\section{f.) Vínculos de classe}

Infelizmente, os dados acerca das origens familiares dos conselheiros são relativamente escassos. Foi possível identificar cinquenta conselheiros oriundos de oligarquias regionais, de famílias com tradição nas carreiras jurídicas, sobretudo na magistratura, ou originários de clãs tradicionais atuantes na política, algumas desde o Império. Em certos casos, estas procedências familiares se superpunham. ${ }^{503}$

\footnotetext{
502 Eram eles: Dario Délio Cardoso, Paulo Martins de Souza Ramos, Fernando Carneiro da Cunha Nóbrega, Antônio Chalbaud Biscaia e José Adriano Marrey Júnior.

503 "As famílias da fração intelectual e política devem sua condição privilegiada ao trabalho especializado que vêm exercendo por sucessivas gerações, sendo impossível dissociar o capital acumulado isoladamente por cada um de seus membros do patrimônio de prestígio e honorabilidade de
} 
Ademais, sabe-se que vários conselheiros federais mantinham estreita ligação com o comércio, a indústria, as finanças e o latifúndio. Alguns deles eram proprietários e outros serviam profissionalmente ao setor privado. Tomemos alguns exemplos. Raul Fernandes foi, por cinco décadas, advogado da família Guinle, além de ter sido diretor da Companhia Pirelli. ${ }^{504}$ Atílio Vivacqua era filho de fazendeiro e, no Congresso Nacional, atuou em favor dos interesses dos cafeicultores. ${ }^{505}$ Nehemias Gueiros era "patrono de conhecidos grupos econômicos que se opunham a Goulart". 506 Miguel Seabra Fagundes integrou o conselho técnico da Confederação Nacional do Comércio. ${ }^{507}$ Samuel Vital Duarte (que viria a ser presidente da OAB no final da década de 1960) foi consultor desta mesma entidade. ${ }^{508}$ Temístocles Marcondes Ferreira era fazendeiro, banqueiro e industrial. Fundou e dirigiu a Companhia Editora Nacional e o Grupo Atlântica de Seguros Sociais. ${ }^{509}$ Alberto Barreto de Melo foi assessor técnico da Associação dos Plantadores de Cana de Sergipe. ${ }^{510}$ Daniel de Carvalho foi vicepresidente da Associação Comercial do Rio de Janeiro, entre 1945 e 1946 e também era grande acionista da Companhia Nacional de Gás Esso, subsidiária da norte-americana Standard Oil. ${ }^{511}$ José Augusto Bezerra de Medeiros presidiu, de 1959 a 1961, a Associação Comercial do Rio de Janeiro e, nos anos 1950, foi membro dos conselhos

\footnotetext{
que todos se beneficiam, como bem o demonstram as inúmeras ocasiões em que procuram fazer valer o acervo de feitos e personagens ilustres do panteão familiar. Os depoimentos de autoria de figuras destacadas dessas dinastias insistem em sublinhar os destinos paralelos da legenda familiar e da história da elite nativa que, nesses casos, coincide com o desenvolvimento das profissões liberais tradicionais em cujas fileiras a maioria de seus integrantes se firmou. Tendo passado a exercer um monopólio virtual quanto ao suprimento de cargos e vantagens nas mais altas instâncias da divisão do trabalho de dominação em virtude das tendências à cooptação que presidem ao recrutamento das elites políticas e intelectuais, podiam distribuir seus membros pelas diferentes alternativas de carreira no espaço da classe dirigente." MICELI, Sergio. Carne e osso da elite política brasileira pós-1930, op. cit., p. 591-592.

${ }^{504}$ OLIVEIRA, João Gualberto de, op. cit., p. 354-356; CARVALHO, Antônio Gontijo de, op. cit, p. 5059 .

${ }^{505}$ VIVACQUA, Atílio. In: ABREU, Alzira Alves de et alli (coord.), op. cit.

${ }^{506}$ COELHO, Fernando, op. cit., p. 44.

${ }^{507}$ CALICCHIO, Vera. FAGUNDES, Seabra. In: ABREU, Alzira Alves de et alli. (coord.), op. cit.

${ }_{508}$ OLIVEIRA, João Gualberto de, op. cit., p. 363.

${ }^{509}$ Ibidem, p. 361-362.

${ }^{510}$ Ibidem, p. p. 362-363.

${ }^{511}$ PANTOJA, Sílvia. CARVALHO, Daniel de. In: ABREU, Alzira Alves de et alli. (coord.), op. cit.
} 
técnicos da Confederação Rural Brasileira e da Confederação Nacional do Comércio. ${ }^{512}$ E, por fim, Cícero Aranha foi diretor do Banco Aliança do Rio de Janeiro. ${ }^{513}$

Assim, a vinculação com o setor privado, a ocupação de altos cargos públicos, sobretudo antes de 1945 (quando estes eram reservados às elites e suas clientelas), as filiações partidárias predominantes (UDN e PSD) e as origens familiares desvelam os fortes laços dos conselheiros federais com as classes dominantes, seja como seus integrantes ou, mais comumente, como seus aliados políticos ou assessores técnicos.

${ }^{512}$ MALIN, Mauro. AUGUSTO, José. In: ABREU, Alzira Alves de et alli. (coord.), op. cit.
${ }^{513}$ Quem é quem no Brasil, op. cit., p. 31; SILVA, Raimundo Nonato, op. cit., p. 305-306. 


\section{CAPÍTULO VI: A RELAÇÃO DO CONSELHO FEDERAL COM O ESTADO}

\section{1.) O Conselho Federal contra o aparato policial}

As frequentes arbitrariedades cometidas pelo aparato policial, especialmente contra os advogados, consistiam um foco permanente de tensão entre o Conselho Federal da $\mathrm{OAB}$ e os governos federal e dos estados durante o período analisado. Em 1946, um episódio de agressão policial a Adauto Lúcio Cardoso mobilizou as entidades de advogados. No dia 31 de agosto daquele ano, o eminente advogado udenista dirigirase à sede da polícia do Distrito Federal para prestar assistência ao também advogado Hélio Walcácer, que se encontrava lá encarcerado. Ligado ao PCB, Walcácer representava os empregados da Light numa queixa-crime que estes apresentaram contra o chefe de polícia do Distrito Federal, José Pereira Lira, a quem apontavam como responsável pelos espancamentos de que tinham sido vítimas durante uma greve na empresa. Dias depois, numa reunião no IAB, Walcácer afirmaria que sua prisão objetivara impedi-lo de comparecer ao julgamento da queixa-crime. Ao chegar à chefia de polícia, Adauto Lúcio Cardoso foi agredido e preso pelo delegado Fredgard Martins Ferreira. $^{514}$

Na sessão do Conselho Federal de 3 de setembro, José Augusto Bezerra de Medeiros apresentou seu protesto contra a violência policial de que Adauto Cardoso havia sido vítima. Depois, solicitou que o mesmo, presente à reunião, fosse ouvido pelo Conselho. Adauto Cardoso, que, neste momento, não era conselheiro federal da $\mathrm{OAB}$, responsabilizou o delegado Fredgard Martins Ferreira pelas agressões e acusou Pereira Lira de conivência com as violências. Então, José Augusto propôs a seguinte moção, aprovada por unanimidade:

"Lançamos daqui o nosso veemente protesto contra a brutalidade policial que atingiu, através de colegas eminentes, a própria dignidade da classe, e

\footnotetext{
${ }^{514}$ Diário de Notícias, 4/9/1946, $1^{\text {a }}$ seção, p. 3 e 8; Diário de Notícias, 6/9/1946, $1{ }^{\text {a }}$ seção, p. 2; $O$ Jornal, 4/9/1946, $1^{\text {a }}$ seção, p. 2.
} 
indicamos que o Sr. Presidente leve às altas autoridades da República a expressão de sua indignação, reclamando providências que conduzam à punição dos criminosos, a desagravar os advogados brasileiros. "515

O conselheiro Macário Picanço propôs a formação de uma comissão de cinco conselheiros para investigar os fatos, determinar os responsáveis e sugerir ao Conselho Federal as medidas administrativas e legais a serem tomadas. Esta proposta não invalidava a de José Augusto, mas parecia mais radical. Foi, contudo, reprovada pela maioria, que entendeu que tal iniciativa caberia à seção carioca da Ordem. ${ }^{516}$ No dia seguinte, a seccional do Distrito Federal reuniu-se para analisar o requerimento apresentado por mais de cem advogados que pediam a convocação da assembleia geral dos advogados cariocas para votar a exclusão de Pereira Lira do cargo de conselheiro seccional da Ordem. Segundo a imprensa, a reunião foi acompanhada por mais de duzentos advogados. $\mathrm{Na}$ ocasião, Adauto Cardoso relatou o episódio, mas pediu, em relação aos responsáveis pela sua agressão, apenas uma condenação moral. Ficou decidido que Pereira Lira teria 15 dias para apresentar sua defesa perante o Conselho Seccional. O órgão ainda registrou um aplauso à moção aprovada no dia anterior pelo Conselho Federal e enviada a Dutra. ${ }^{517} \mathrm{O}$ episódio colocava à prova a independência da seção carioca da $\mathrm{OAB}$ em relação à Light - à qual boa parte de seus membros estava vinculada, inclusive o presidente em exercício da OAB Pinto Lima, filiado à Chapa Azul - não apenas porque na origem dos acontecimentos estava uma greve na empresa, mas também porque Pereira Lira fora diretor do departamento jurídico da mesma. ${ }^{518}$

O IAB também realizou uma sessão para debater o episódio. Bruno de Almeida Magalhães apresentou um requerimento para que o Instituto manifestasse sua

\footnotetext{
${ }^{515}$ CF-OAB, Ata de sessão do Conselho Federal, 3/9/1946.

${ }^{516}$ CF-OAB, Ata de sessão do Conselho Federal, 3/9/1946.

517 Diário de Notícias, 4/9/1946, $1^{\text {a }}$ seção, p. 3 e 8; Correio da Manhã, 4/9/1946, p. 12; O Jornal, 4/9/1946, $1^{\text {a }}$ seção, p. 2; O Jornal, 5/9/1946, $1^{\text {a }}$ seção, p. 3 e 7.

518 Cf. o depoimento de Ricardo Lira, filho de José Pereira Lira, em: $<$ http://www.Direitouerj.org.br/2005/fdir70/depRL.htm>. Acesso em: 30/8/2010. Cf, também: BANDEIRA, Moniz. Presença dos Estados Unidos no Brasil. Rio de Janeiro: Civilização Brasileira, 1973, p. 311.
} 
reprovação à atitude de Pereira Lira, que era sócio da entidade. ${ }^{519}$ Por sua vez, Sobral Pinto apresentou uma moção de solidariedade a Adauto Cardoso e Hélio Walcácer e, ao mesmo tempo, de protesto contra o "sócio deste Instituto, sr. José Pereira Lira, que, na qualidade de chefe de Polícia, que dirige, não soube zelar, dentro do Distrito Federal, os direitos sagrados da pessoa humana e as prerrogativas da advocacia." ${ }^{2520}$ Esta moção foi aprovada apesar dos votos contrários de Luís Gallotti, Himalaia Virgolino, Rubens Ferraz e Vicente Chermont Miranda. ${ }^{521}$ Também o Clube dos Advogados e a seção fluminense da OAB solidarizaram-se com Adauto Cardoso e Hélio Walcácer. Ao longo do mês de setembro, o Conselho Federal recebeu cartas e telegramas de advogados e de seccionais da Ordem (Rio Grande do Sul, Minas Gerais e Sergipe) manifestando solidariedade aos dois advogados ou apoio à moção aprovada pelo órgão. 522

Na sessão de 27 de abril de 1948, o Conselho Federal tomou conhecimento de telegrama enviado pelo advogado Aristides Saldanha, no qual contava ter ido para Maceió defender parlamentares comunistas acusados pelo assalto à cadeia de São Luís Quitunde. Saldanha chegara à cidade no dia 18 de abril e, no dia 20, fora preso no Hotel Bela Vista e conduzido à penitenciária da cidade. À noite, fora surpreendido, em sua cela por um grupo de quinze detentos chefiados pelo responsável pelo presídio. Amordaçado, tivera os pulsos amarrados e um saco colocado na cabeça. Em seguida, fora jogado num carro com um de seus constituintes. Na viagem, foram, ambos, ameaçados de morte e espancados. Finalmente, por volta das seis da manhã do dia seguinte, foram abandonados como estavam, amordaçados e amarrados, numa praia do

${ }^{519}$ Diário de Notícias, 6/9/1946, $1^{\text {a }}$ seção, p. 2.

${ }^{520}$ Diário de Notícias, 6/9/1946, $1^{\text {a }}$ seção, p. 2.

${ }^{521}$ Destes, ao menos os três primeiros pareciam próximos ao governo federal. Gallotti seria, mais tarde, nomeado por Dutra ministro do STF. Além disto, seu irmão Antônio Gallotti era alto funcionário da Light. Virgolino fora juiz do Tribunal de Segurança Nacional. Ambos haviam sido dirigentes da Ação Integralista Brasileira (AIB). Já Rubens Ferraz era funcionário de polícia. Diário de Notícias, 6/9/1946, $1^{\text {a }}$ seção, p. 2; BRANDI, Paulo. GALLOTTI, Luís. In: ABREU, Alzira Alves de et alli. (coord.), op. cit.; DIAS, Sônia. GALLOTTI, Antônio. In: ABREU, Alzira Alves de et alli. (coord.), op. cit.; VIRGOLINO, Himalaia. In: ABREU, Alzira Alves de et alli. (coord.), op. cit. Como se vê, à semelhança do que ocorria no Conselho Federal da OAB, apesar da hegemonia udenista no IAB, era marcante a presença de bacharéis vinculados a Dutra e ao PSD.

${ }^{522}$ Diário de Notícias, 6/9/1946, $1^{\text {a }}$ seção, p. 2; CF-OAB, Atas de sessão do Conselho Federal, 10/9/1946, 17/9/1946 e 24/9/1946. 
litoral pernambucano. Aristides Saldanha encerrava o telegrama afirmando haver provas de que o mandante da agressão havia sido o governador alagoano. ${ }^{523}$ Vinculado ao PCB, Saldanha seria eleito, em 1950, vereador no Distrito Federal. ${ }^{524}$

Nesta mesma sessão, o presidente Pinto Lima propôs uma moção de protesto contra as agressões que o udenista Carlos Lacerda sofrera, dez dias antes, em frente à rádio Mayrink Veiga, onde era comentarista político. Quando chegava à rádio para ler o seu comentário, o jornalista fora espancado por cinco homens. ${ }^{525}$ Note-se a indignação seletiva de Pinto Lima, pois ele não se pronunciou sobre as violências cometidas contra Aristides Saldanha - um advogado, porém comunista. Depois de fazer sua proposta, Pinto Lima acrescentou:

"Vigilante como é o Conselho Federal, órgão supremo da ORDEM DOS ADVOGADOS DO BRASIL, em todos os assuntos e fatos que dizem respeito à liberdade, aos direitos individuais e à Ordem Pública, não precisarei justificar o voto em tal sentido que submeto à apreciação deste Conselho.' "1526

Em seguida, o conselheiro Nelson Carneiro tratou das dificuldades que os advogados estavam enfrentando para defender pessoas com militância política, numa alusão, ao que parece, aos comunistas - em pleno período de emergência da Guerra Fria e de caça aos comunistas no Brasil. E propôs um substitutivo à proposta de Pinto Lima que não se limitava ao episódio de agressão a Carlos Lacerda, mas alertava para os sucessivos ataques às prerrogativas profissionais dos advogados ${ }^{527}$ :

\footnotetext{
${ }^{523}$ CF-OAB, Ata de sessão do Conselho Federal, 27/4/1948.

${ }^{524}$ BUONICORE, Augusto César. Os comunistas e a estrutura sindical corporativa (1948-1952). Campinas, 1996. Dissertação (Mestrado em Ciência Política). UNICAMP, p. 37.

${ }^{525}$ CF-OAB, Ata de sessão do Conselho Federal, 27/4/1948; Diário de Notícias, 18/4/1948, $1^{\text {a }}$ seção, p. 2.

${ }^{526}$ CF-OAB, Ata de sessão do Conselho Federal, 27/4/1948.

${ }^{527}$ Em artigo publicado, em 29 de abril de 1948, no Diário de Notícias, o jornalista Rubem Braga acusou o governo federal de uma série de arbitrariedades contra seus opositores e mencionou a agressão a Aristides Saldanha: "em Alagoas um advogado e seu constituinte são espancados, metidos em sacos e jogados numa praia deserta”. Diário de Notícias, 29/4/1948, 1ª seção, p. 3.
} 
"O Conselho Federal da Ordem dos Advogados do Brasil - na defesa, a que nunca faltou, do regime legal - manifesta, de público, o seu veemente protesto contra violações do texto constitucional, que se vão perpetrando no país, e que, já não só perturbam, mas até impossibilitam o livre exercício da profissão. Atentados pessoais e violências sucessivas, voltam a intranquilizar a família brasileira, com excessos que podem abrir clareiras para a restauração da época de truculências e de discricionarismo, unanimemente repelida pela consciência jurídica nacional. E reitera a sua confiança em que o Governo tomará amplas e enérgicas providências no sentido de que à apuração das responsabilidades, que quaisquer que sejam os culpados por tais violações se assegurem as necessárias garantias, a fim de que se restaure no país o clima de tranquilidade indispensável à manutenção da ordem constitucional. ${ }^{, 528}$

Os conselheiros Temístocles Marcondes Ferreira e Anuar Farah, receosos, talvez, de que o Conselho Federal se indispusesse com autoridades federais e estaduais, posicionaram-se contra o pronunciamento a respeito dos episódios de agressão contra advogados sob a alegação de que o artigo $8^{\circ}$ do Estatuto da Ordem proibia este tipo de atitude. ${ }^{529}$ Venceu, porém, a posição dos conselheiros que consideravam o protesto contra os casos de violência um dever da $\mathrm{OAB}$ em defesa da ordem jurídica e da própria advocacia. Assim, os conselheiros, por maioria, aprovaram a proposta de Nelson Carneiro. Alguns votaram pela proposta de Pinto Lima, claramente restritiva ao contemplar apenas a agressão a Lacerda. Além disto, o Conselho decidiu solidarizar-se com Aristides Saldanha e fazer gestões junto ao ministro da Justiça para que os fatos fossem apurados. O órgão também deliberou comunicar a Dutra e ao governador de Alagoas as decisões tomadas naquela ocasião. ${ }^{530}$ Com efeito, na reunião de 4 de maio, Pinto Lima informou ao Conselho Federal ter conversado com o ministro da Justiça sobre a agressão a Aristides Saldanha. Nesta sessão, foi lido um telegrama do presidente

\footnotetext{
${ }^{528}$ CF-OAB, Ata de sessão do Conselho Federal, 27/4/1948.

${ }^{529} \mathrm{O}$ artigo $8^{\circ}$ do Estatuto de 1933 estabelecia: "A diretoria, o Conselho e a assembleia não discutirão, nem se pronunciarão sobre assunto imediatamente não atinente aos objetivos da Ordem."

${ }^{530}$ CF-OAB, Ata de sessão do Conselho Federal, 27/4/1948.
} 
da seção alagoana da Ordem que relatava as providências tomadas pelo organismo a respeito do episódio. ${ }^{531}$

Na sessão de 18 de maio de 1954, o Conselho Federal aprovou uma moção apresentada por Letácio Jansen condenando casos recentes de violência policial. O conselheiro Marcondes Ferreira, no entanto, absteve-se de votar, alegando ser contrário a qualquer tipo de pronunciamento feito pelo órgão sobre assuntos alheios aos objetivos da OAB. A moção, enviada ao ministro da Justiça, Tancredo Neves, e publicada pelos jornais cariocas ${ }^{532}$, dizia:

"O Conselho Federal (...) no ensejo de novos atentados à dignidade da pessoa humana, cometidos por autoridades policiais desmandadas, em vários pontos do país e principalmente na Capital da República, manifesta a Vossa Excelência o seu mais enérgico protesto contra as violências e arbitrariedades que se tem verificado e formula a esperança de que Vossa Excelência, responsável pelos problemas da segurança pública do país, dentro das determinações constitucionais, há de concorrer com sua autoridade para exemplar punição dos culpados e para saneamento das corporações policiais. ${ }^{\text {"533 }}$

$\mathrm{Na}$ realidade, o fato que desencadeou a reação do Conselho Federal foi o espancamento do jornalista Nestor Moreira, do diário A Noite, pelo policial Paulo Peixoto, na madrugada de 11 de maio daquele ano, na delegacia de polícia de Copacabana, no Rio de Janeiro. O repórter chegou à delegacia após discutir com o motorista do táxi que tomara. Nestor Moreira agonizou no hospital até 22 de maio, quando morreu. Mesmo antes de sua morte, o episódio alcançou grande repercussão, recebendo ampla cobertura da imprensa. A Associação Brasileira de Imprensa (ABI), o PSB e a Assembleia Legislativa de São Paulo protestaram contra a violência. Segundo

\footnotetext{
${ }^{531}$ CF-OAB, Ata de sessão do Conselho Federal, 4/5/1948.

532 O Jornal, 19/5/1954, $2^{\circ}$ caderno, p. 1 e 6; Diário de Notícias, 19/5/1954, $1^{\text {a }}$ seção, p. 6; Correio da Manha, 19/5/1954, $1^{\circ}$ caderno, p. 5.

${ }^{533}$ CF-OAB, Ata de sessão do Conselho Federal, 18/5/1954.
} 
Edmar Morel, duzentas mil pessoas acompanharam o cortejo fúnebre do jornalista. O episódio Nestor Moreira foi usado pela oposição a Vargas como um elemento da campanha de desestabilização movida contra o governo. Vários líderes oposicionistas, incluindo Carlos Lacerda, compareceram ao enterro do jornalista. O ministro da Justiça viu-se obrigado - ainda antes da morte de Moreira - a conceder uma entrevista à imprensa, na sede da $\mathrm{ABI}$, onde prometeu a punição dos policiais culpados pela agressão e anunciou uma "reforma estrutural" da polícia carioca. Na esteira do episódio, surgiram outras denúncias de violência policial - não apenas contra jornalistas, mas também contra trabalhadores. ${ }^{534}$

Na sessão do Conselho Federal de 29 de outubro de 1957, Luís Mendes de Morais levantou-se contra o chefe de polícia do Distrito Federal, que, numa reunião ocorrida na Associação Comercial do Rio de Janeiro, teria defendido ações policiais nas quais se matassem criminosos durante as diligências. $\mathrm{O}$ conselheiro federal solicitou que o órgão condenasse a declaração do chefe de polícia e encaminhasse a ele o seu protesto, assim como ao presidente da Associação Comercial (que teria aprovado as palavras do chefe de polícia), ao ministro da Justiça e ao presidente da República. ${ }^{535} \mathrm{Na}$ sessão de 19 de novembro, o Conselho Federal examinou a proposta de Mendes de Morais e, por maioria, não a aprovou. Na ocasião, Carlos Bernardino de Aragão Bozano apresentou uma declaração de voto que desvelava as limitações que a posição social dos conselheiros federais impunha à sua adesão aos princípios liberais, como as liberdades civis. O conselheiro iniciou sua intervenção fazendo uma declaração de princípios e invocou sua autoridade para se pronunciar sobre o assunto pelo seu engajamento antiestadonovista:

"Condenei e combati, por todos os meios ao meu alcance, desmandos de policiais, sobretudo em época trevosa, a da ditadura estadonovista (...) Condeno

\footnotetext{
${ }^{534}$ O Jornal, 19/5/1954, $2^{\text {o }}$ caderno, p. 1 e 6; Diário de Notícias, 19/5/1954, $1^{\text {a }}$ seção, p. 6; Correio da Manha, 19/5/1954, $1^{\circ}$ caderno, p. 5; MOREL, Edmar. Histórias de um repórter. Rio de Janeiro: Record, 1999, p. 223; D’ARAÚJO, Maria Celina. O Segundo Governo Vargas, 1951-1954. Democracia, partidos e crise política. Rio de Janeiro: Zahar Editores, 1982, p. 123.

${ }^{535}$ CF-OAB, Ata de sessão do Conselho Federal, 29/10/1957.
} 
inexoravelmente, combato implacavelmente a todos os policiais desonestos e violentos. ${ }^{, 536}$

No entanto, em seguida, defendeu o emprego da "força legítima" contra os bandidos da capital da República e a necessidade de se apoiar a atuação da polícia:

"Agora, no entanto, o que se pretende é condenar não as violências desnecessárias, mas, sim, o uso da legítima defesa, que é esta, sem dúvida, a posição dos agentes policiais frente às figuras sinistras que infestam a Capital da República. Cidadãos com pagas miseráveis, integrando uma corporação deficiente, em número e em aparelhamento de qualquer espécie, necessitam, para o cumprimento da sua missão, ao menos de uma palavra de apoio e de encorajamento dos seus superiores, máxime ao serem jogados ao combate contra feras que se não atêm a qualquer regra. ",537

Depois, Aragão Bozano atribuía aos policiais maiores direitos que aos bandidos:

"Fala-se no respeito à pessoa humana. Este deve existir, é claro, mas se deve manifestar com maior razão no tocante àqueles que defendem a lei. Cita-se o drama dos 'marginais'. Ele existe e deve ser estudado e resolvido, cientificamente, sem demagogias. Mas e o drama pessoal e familiar dos agentes da Polícia? „538

Finalmente, o conselheiro federal confessava o seu temor, o da convulsão social. Apostava na polícia para manter a população pobre do Rio de Janeiro contida nos morros:

${ }^{536}$ CF-OAB, Ata de sessão do Conselho Federal, 19/11/1957.
${ }_{337}$ CF-OAB, Ata de sessão do Conselho Federal, 19/11/1957.
${ }^{538}$ CF-OAB, Ata de sessão do Conselho Federal, 19/11/1957. 
"Imaginaram, porventura, os Srs. Conselheiros o que seria da capital brasileira, se, amanhã, os morros que a circundam em boa parte descessem sobre ela em forma de violência ou de epidemia? Pensaram já? Devemos todos, cidadãos que aqui vivemos, contribuir, na medida das nossas forças, para o crescente prestígio da autoridade legítima." 539

Deve-se, outrossim, questionar os móveis de Morais Neto na sua proposição. Integrante do Conselho Federal da OAB entre 1957 e 1960, esta foi a única vez em que levantou a voz contra a truculência policial. Mais do que por sentimentos humanitários ou convicções liberais, Morais Neto poderia estar animado pelo seu radical oposicionismo a Juscelino Kubitscheck, que o tornaria um dos protagonistas da Revolta de Aragarças. ${ }^{540}$

Ainda em 1957, o Conselho Federal da OAB ofereceu proteção a Edú Potiguara Bublitz, advogado de posseiros paranaenses em litígio com companhias colonizadoras. O conflito alcançou repercussão nacional e resultou em várias mortes. Bublitz compareceu à reunião do Conselho Federal de 8 de novembro de 1957. Denunciou, nesta ocasião, que estava sendo perseguido pela polícia do Paraná e que já havia sido encarcerado por ordem do secretário de Segurança Pública daquele estado. Ele acrescentou já ter recorrido à seção estadual da Ordem, que lhe prestara "todo o apoio”. Porém, como o próprio governador do Paraná estava envolvido na contenda, apelava ao Conselho Federal para que o órgão intercedesse junto ao ministro da Justiça para lhe assegurar o exercício da advocacia. ${ }^{541}$ Luís Mendes de Morais Neto, que dirigia os trabalhos na sessão de 8 de novembro, passou a presidência a José Maria Mac Dowell da Costa declarando-se impedido de continuar a presidir a reunião porque era advogado da Clevelândia Industrial e Territorial (CITLA), uma das companhias colonizadoras envolvidas no conflito. O Conselho Federal decidiu pedir informação à seção estadual da Ordem e comunicar-se com o ministro da Justiça, solicitando as

\footnotetext{
${ }^{539}$ CF-OAB, Ata de sessão do Conselho Federal, 19/11/1957.

${ }^{540}$ LAMARÃO, Sérgio. Revolta de Aragarças. In: ABREU, Alzira Alves de et alli. (coord.), op. cit.

${ }^{541}$ CF-OAB, Ata de sessão do Conselho Federal, 8/11/1957.
} 
garantias para o advogado, caso isto fosse aconselhado pela seção paranaense da OAB. Também orientou que o advogado impetrasse habeas corpus junto à Justiça paranaense e assumiu a defesa do advogado, por meio de Alcino Salazar, se o caso chegasse ao STF. $^{542}$

$\mathrm{Na}$ sessão seguinte, como a seção paranaense não havia respondido à consulta, o Conselho Federal decidiu telefonar para o presidente da OAB do Paraná. Ademais, o conselheiro Alcino Salazar informou que o advogado Justo de Morais, pai de Luís Mendes de Morais Neto e igualmente advogado da CITLA, lhe relatara ter telegrafado ao governador do Paraná solicitando que fossem dadas a Edú Bublitz todas as garantias para o exercício profissional. ${ }^{543}$ Dias depois, a OAB paranaense comunicou ao Conselho Federal as providências tomadas anteriormente em favor de Bublitz, que pedira proteção à seção estadual por se sentir ameaçado pela polícia e por "capangas das Companhias de Terras". A seção estadual da OAB obtivera garantias da Corregedoria Geral da Justiça e do Chefe de Polícia. Mesmo assim, continuava o comunicado, Bublitz fora preso. A OAB paranaense protestou contra a prisão arbitrária e conseguiu que o advogado fosse libertado. ${ }^{544}$ Dias depois, o conselheiro federal Mac Dowell da Costa foi recebido pelo ministro da Justiça, a quem pediu garantias de vida a Bublitz. $^{545}$

Até o golpe civil-militar de 1964, o Conselho Federal interpelou mais umas poucas vezes as autoridades governamentais para garantir proteção a advogados atingidos por arbitrariedades policiais. Em dezembro de 1961, o organismo atuou em favor do advogado gaúcho Deburgo de Deus Vieira. Militante comunista, Vieira, que havia sido candidato à Assembleia Nacional Constituinte pelo PCB, em 1945, fora agredido pela polícia da Guanabara. ${ }^{546}$ Em 1960 e, também, em 1962, o Conselho

\footnotetext{
${ }^{542}$ CF-OAB, Ata de sessão do Conselho Federal, 8/11/1957.

543 CF-OAB, Ata de sessão do Conselho Federal, 12/11/1957.

${ }^{544}$ CF-OAB, Ata de sessão do Conselho Federal, 19/11/1957.

545 CF-OAB, Ata de sessão do Conselho Federal, 19/11/1957.

${ }^{546} \mathrm{CF}-\mathrm{OAB}$, Ata de sessão do Conselho Federal, $<$ http://www.vermelho.org.br/coluna.php?id_coluna_texto=344\&id_coluna=14>. Acesso em 24/10/2010; DORS, Marines. Dyonélio Machado (1895-1985): os múltiplos fios da trajetória ambivalente de um intelectual. São Leopoldo, 2008. Dissertação (Mestrado em História). UNISINOS, p. 131 , nota 162.
} 
Federal recebeu denúncias de violências policiais sofridas, no exercício da profissão, pelo advogado Cícero Borges Bordalo, no Amapá. Nas duas ocasiões, segundo as atas do Conselho Federal, o presidente da OAB limitou-se a determinar o envio de telegramas ao ministro da Justiça para pedir providências. ${ }^{547}$

A afirmação institucional da Ordem dependia destes posicionamentos, fortalecidos pelas convicções liberais de muitos conselheiros federais. Logo se percebe o risco persistente que representava ao Conselho Federal o apoio a governos autoritários, como o de Dutra ou o de Castelo Branco, pois mais cedo ou mais tarde, as arbitrariedades estatais atingiam também os advogados. Observe-se ainda que a defesa do exercício da advocacia pelo Conselho Federal, nestas situações, era dotada de uma dimensão democrática, ao amparar a militância profissional de advogados ligados às classes populares, como comunistas e advogados de camponeses. Por duas vezes, em episódios de proteção ao exercício da profissão, as contradições sociais explicitaram-se no interior do Conselho Federal, que abrigou, nas suas reuniões, conselheiros federais que defendiam os interesses do capital (da Light e da CITLA) e advogados que defendiam os interesses de trabalhadores e de posseiros de terra.

Contudo, considerando todo o período estudado neste trabalho, foram raras as ações do Conselho Federal da OAB em defesa de advogados atingidos pelo arbítrio policial. É possível que os advogados recorressem mais freqüentemente às seções estaduais da Ordem para obterem este amparo. Entretanto, é verdade que o Conselho Federal socorreu os advogados agredidos sempre que foi solicitado, reagindo às violências denunciadas por meio da divulgação de moções de protesto (que alcançavam alguma repercussão pública, graças ao prestígio do órgão) e interpelando o governo, especialmente o ministro da Justiça. Todavia, apenas uma pesquisa mais ampla poderia apontar a real eficácia de tais ações.

\section{2.) A mobilização pela autonomia da $\mathbf{O A B}$}

\footnotetext{
${ }^{547}$ CF-OAB, Atas de sessão do Conselho Federal, 19/7/1960 e 7/8/1962.
} 
Desde a sua criação, a atuação da Ordem alicerçou-se sobre o princípio da autonomia em relação ao Estado. Os seus dirigentes enfrentaram vigorosamente todas as tentativas estatais de estabelecer algum nível de controle sobre a entidade. A natureza jurídica da $\mathrm{OAB}$ esteve no centro dos debates sobre sua autonomia em relação ao Estado. O Estatuto de 1933, no seu artigo 2º definia a Ordem como “serviço público federal" e, por consequência, isentava seus bens e serviços de impostos e contribuições. $\mathrm{O}$ estatuto não previa vínculos de subordinação da $\mathrm{OAB}$ em relação a qualquer órgão estatal.

Todavia, em 1949, o Tribunal de Contas da União, considerando a Ordem dos Advogados uma autarquia, cobrou-lhe a prestação de contas. ${ }^{548}$ O Conselho Federal logo incumbiu José Teles da Cruz de examinar a cobrança do tribunal. Na sessão de 14 de junho de 1949, o conselheiro federal apresentou o seu parecer, no qual concordava que a $\mathrm{OAB}$ fosse uma autarquia e, portanto, devesse fazer sua prestação de contas ao TCU. ${ }^{549}$ Porém, no início de setembro, o conselheiro federal Arnoldo Medeiros da Fonseca apresentou um parecer substitutivo ao de Teles da Cruz. Aprovado pelo Conselho Federal por unanimidade, o novo parecer repelia o enquadramento legal da Ordem dos Advogados como autarquia. ${ }^{550}$ Finalmente, no início de maio de 1950, Dario de Almeida Magalhães apresentou ao Conselho um longo arrazoado de vinte páginas acerca da natureza jurídica da $\mathrm{OAB}$, no qual o conselheiro federal considerava a Ordem uma entidade jurídica sui generis e não uma autarquia. Ademais, propunha que a OAB acionasse a Justiça para não ter de apresentar sua prestação de contas ao TCU. No item 20 de seu parecer, afirmava:

"A plena independência [da $\mathrm{OAB}]$ lhe é essencial, não só à dignidade da instituição, como à própria eficiência de sua atividade peculiar. A independência

\footnotetext{
548 Ata de sessão do Conselho Federal, 2/8/1949 publicada no Jornal do Comércio, 14/8/1949, p. 7.

${ }^{549}$ Ata de sessão do Conselho Federal, 14/6/1949 publicada no Jornal do Comércio, 28/6/1949, p. 4.

${ }^{550}$ Ata de sessão do Conselho Federal, 6/9/1949 publicada no Jornal do Comércio, 12-13/9/1949, p. 2.
} 
da Ordem protege a independência do advogado; e sem esta a profissão decai de sua grandeza e de sua utilidade social." 551

O parecer foi aprovado por unanimidade pelas delegações estaduais - apenas o conselheiro Martins de Almeida manifestou-se contrariamente a ele. Na mesma sessão, o Conselho deliberou recorrer ao Judiciário para impedir a pretensão do Tribunal de Contas. ${ }^{552}$ Em 1952, o Tribunal Federal de Recursos (TRF) confirmou sua decisão tomada no ano anterior, que desobrigou a OAB de prestar contas ao TCU, encerrando, deste modo, a contenda entre a Ordem e o Tribunal de Contas. ${ }^{553}$

Os móveis que levaram o TCU a questionar a autonomia da OAB continuam obscuros. As fontes documentais empregadas neste trabalho mostraram-se inteiramente insuficientes para a compreensão das motivações do tribunal. Maria da Glória Bonelli sugere ter-se tratado de uma represália do governo Dutra, por intermédio do tribunal, contra o udenismo do Conselho Federal da OAB. ${ }^{554}$ A tese é plausível, mas ainda carece de fundamentação documental. Complementarmente, pode-se sugerir que os protestos da OAB contra violências infligidas pelo aparato policial a advogados estejam, igualmente, na origem da atitude do TCU.

Antecipando-se a outras tentativas governamentais de limitar a sua autonomia, o Conselho Federal procurou prevenir-se ao elaborar o projeto de novo estatuto da OAB. Este previa: "Dada a sua natureza corporativa e a peculiaridade de suas funções, não se aplicam à Ordem as disposições legais referentes às autarquias ou entidades paraestatais. "555 Porém, na tramitação do projeto na Câmara dos Deputados, Milton Campos, procurando afastar a ambiguidade carregada pelo adjetivo “corporativo”, manteve o perfil jurídico contido no Estatuto de 1933, caracterizando-a

\footnotetext{
${ }^{551}$ CF-OAB, Ata de sessão do Conselho Federal, 2/5/1950.

${ }^{552}$ CF-OAB, Ata de sessão do Conselho Federal, 2/5/1950; VENÂNCIO FILHO, Alberto. Notícia histórica da $O A B$, op. cit., p. 77-85.

${ }^{553}$ VENÂNCIO FILHO, Alberto. Notícia histórica da $O A B$, op. cit., p. 85.

554 "É no período democrático de 1946-64 que a OAB partilha a experiência de defender sua autonomia. Identificada pelo governo eleito do marechal Dutra como tendo apoiado o candidato derrotado da UDN, em represália, ele ataca a independência da Ordem em relação ao Estado. ” BONELLI, Maria da Glória, op. cit., p. 60.

${ }_{555}$ BASTOS, Aurélio Wander, op. cit., p. 324.
} 
como "serviço público federal". ${ }^{556}$ Esta definição da natureza jurídica da Ordem dos Advogados prevaleceu no texto do Estatuto de 1963, que, além de confirmar a imunidade tributária de que gozava o órgão, manteve o dispositivo que a deixava fora do alcance da legislação referente às autarquias e entidades paraestatais (artigo 139).

Assim, o Conselho Federal logrou manter a natureza sui generis da OAB. Tratava-se de um organismo a desempenhar funções públicas, porém livre da fiscalização governamental. Além disto, era dirigida por elementos que não haviam sido designados pelo governo ou pelo corpo eleitoral do país, mas indicados pela própria categoria profissional. A cúpula da $\mathrm{OAB}$ defendia a autonomia da entidade em relação ao Estado como condição sine qua non para o pleno exercício da advocacia. A autonomia da $\mathrm{OAB}$, afirmava o seu presidente Nehemias Gueiros na abertura da $1^{\mathrm{a}}$ Conferência Nacional da Ordem,

"que nos assegura um dos pressupostos indispensáveis da profissão: a independência, assim a que deve ser inata ao caráter e ao temperamento do advogado, como condição da bravura necessária à defesa dos direitos e interesses que lhe são confiados como a que decorre da ausência de qualquer subordinação hierárquica ou funcional. "557

\section{3.) A relação com o Congresso Nacional}

Não apenas o Executivo representava uma ameaça potencial à Ordem, com suas tentativas de submetê-la ao seu controle, mas também o Legislativo, que, a qualquer momento, podia alterar artigos do Estatuto da Ordem, transformando suas atribuições e modo de funcionamento. De todo modo, a presença de vários conselheiros no Congresso Nacional foi importante para assegurar a manutenção do controle da categoria dos advogados pela $\mathrm{OAB}$ nos termos em que ele estava estabelecido. Não foram raras as ocasiões em que a entidade apelou à sua bancada de senadores e

\footnotetext{
${ }^{556}$ BASTOS, Aurélio Wander, op. cit., p. 324; VENÂNCIO FILHO, Alberto. Notícia histórica da OAB, op. cit., p. 102.

${ }^{57}$ Anais da $1^{a}$ Conferência Nacional da Ordem dos Advogados do Brasil, op. cit., p. 9.
} 
deputados federais para que barrasse projetos de lei que abrandavam as exigências para o exercício e o ingresso na profissão.

O Conselho Federal mobilizava sua bancada parlamentar para garantir sua consolidação institucional, assim como para alargar sua jurisdição, como ficou evidente na luta pela aprovação do projeto que lhe dava o direito de participar dos concursos para nomeação de juízes substitutos. Na ação em prol da corporação não havia distinção entre os conselheiros-parlamentares da UDN e os do PSD. Todos se empenhavam em defender os interesses da OAB no Congresso Nacional. Há mesmo o episódio em que Nelson Carneiro colocou-se contra um projeto de lei de um colega seu de bancada udenista baiana, o deputado Gilberto Valente. Sabe-se que, ao menos em 1947, funcionava no interior do Conselho Federal uma comissão integrada por conselheiros que também eram parlamentares, cuja finalidade era acompanhar os projetos que tramitavam no Congresso Nacional e eram do interesse dos advogados e da Ordem. ${ }^{558}$

São vários os exemplos de mobilização do Conselho Federal para derrotar projetos de lei em tramitação no Congresso Nacional. Em 1947, o órgão tomou conhecimento da proposição acima mencionada, de autoria do deputado Gilberto Valente, para alterar a redação do artigo 101 do Estatuto da Ordem, referente ao registro de títulos de advogados, provisionados e solicitadores. O Conselho Federal colocou-se contra o projeto de lei e aprovou um projeto alternativo, elaborado pelo conselheiro federal e também deputado Nelson Carneiro, que seria apresentado, pelas mãos do autor, à Câmara dos Deputados. ${ }^{559}$ Em 1954, por iniciativa de Carlos Bernardino de Aragão Bozano, o Conselho Federal posicionou-se contra um projeto de lei do deputado federal Paulo Coelho que permitia o exercício da advocacia na justiça trabalhista a nãoadvogados que tivessem feito um curso de legislação sindical e do trabalho. Por unanimidade, o órgão "deliberou encarecer a todos os Conselheiros que sejam parlamentares que envidem esforços na Câmara, pela rejeição de tão estranho projeto de lei. ${ }^{\prime 560}$ Em 1957, o Conselho Federal, depois de examinar o projeto de lei do

\footnotetext{
${ }^{558}$ CF-OAB, Ata de sessão do Conselho Federal, 29/7/1947.

${ }^{559}$ CF-OAB, Atas de sessão do Conselho Federal, 26/8/1947 e 9/9/1947.

${ }^{560}$ CF-OAB, Ata de sessão do Conselho Federal, 20/7/1954.
} 
deputado Oliveira Franco, que autorizava a atuação profissional, em todo o território nacional, dos solicitadores com mais de dez anos de serviço, dirigiu-se à Câmara dos Deputados para pleitear a rejeição do projeto. ${ }^{561}$

Outras vezes, o Conselho Federal mobilizou-se para aprovar projetos de lei de seu interesse. Na sessão de 22 de novembro de 1949, o conselheiro Alcino Salazar relatou a seus colegas que o projeto de lei referente à participação da $\mathrm{OAB}$ nos concursos de juiz-substituto já fora aprovado pelo Senado e remetido à Câmara. Salazar ainda elogiou a atuação do conselheiro federal José Ferreira de Sousa, senador pela UDN-RN, em defesa do projeto, no Senado. Finalmente, apelou aos conselheiros que também eram deputados que se esforçassem para garantir a rápida aprovação do projeto na Câmara. ${ }^{562}$ No dia 23 de setembro de 1952, o conselheiro e deputado federal Ulisses Guimarães informou que já apresentara à Câmara dos Deputados, na condição de relator, parecer sobre projeto de lei que fixava as normas para a participação da $\mathrm{OAB}$ em concursos para a magistratura, acrescentando que ele fora aprovado. Depois de ler ao Conselho o parecer em questão, o conselheiro-deputado foi felicitado pelo conselheiro Teles da Cruz "pela excelência de seu trabalho, que corporifica o pensamento da Ordem dos Advogados sobre sua participação efetiva nos concursos para a magistratura. ${ }^{1563}$

O Conselho Federal, por vezes, era consultado pelo Congresso Nacional a propósito de projetos de lei que tratavam da advocacia, da $\mathrm{OAB}$ e da organização do Judiciário. Em dezembro de 1948, o Conselho Federal recebeu do senador Atílio Vivacqua, presidente da Comissão de Constituição e Justiça do Senado Federal (e que viria a ser presidente da Ordem entre 1952 e 1954), um ofício solicitando-lhe um parecer sobre um projeto de lei que assegurava aos provisionados a inscrição nos quadros da Ordem. ${ }^{564}$ No ano seguinte, Osvaldo Vergara, conselheiro federal da OAB e deputado federal pelo PSD-RS, intercedeu junto ao também deputado Hermes Lima, relator de um projeto que alterava artigos do Estatuto da OAB referentes a

\footnotetext{
${ }^{561}$ CF-OAB, Ata de sessão do Conselho Federal, 30/7/1957.

${ }_{562}$ Ata de sessão do Conselho Federal, 22/11/1949 publicada no Jornal do Comércio, 27/11/1949, p. 6.

${ }^{563}$ CF-OAB, Ata de sessão do Conselho Federal, 23/9/1952.

${ }^{564}$ CF-OAB, Ata de sessão do Conselho Federal, 28/12/1948.
} 
impedimentos ao exercício da advocacia, para que o Conselho Federal da Ordem fosse ouvido acerca da proposta. ${ }^{565}$ Em 1954, o Senado Federal pediu o parecer do Conselho Federal sobre um projeto de lei que estabelecia novos critérios para a escolha de advogados e membros do Ministério Público para o cargo de desembargador. ${ }^{566}$

Contando com uma capacidade persuasiva significativa junto ao Congresso Nacional, o Conselho Federal da OAB tecia alianças com parlamentares que exerciam funções-chaves nas casas legislativas. Tome-se o exemplo do relacionamento do órgão com o deputado udenista José Bonifácio Lafayette de Andrada, primeiro-secretário da mesa da Câmara dos Deputados desde 1958. Em meados de 1959, a pedido do presidente da OAB Alcino Salazar, José Bonifácio determinou o desarquivamento de projetos de lei sobre a inscrição provisória nos quadros da $\mathrm{OAB}$ e o salário mínimo dos advogados e providenciou a redistribuição do projeto sobre a aposentadoria dos advogados, em tramitação na Comissão de Legislação Social. Agradecido, Salazar “ressaltou a preciosa colaboração do Deputado José Bonifácio aos assuntos de interesse da Ordem dos Advogados, determinando à Secretaria [que] externasse os agradecimentos da Casa àquele ilustre parlamentar". ${ }^{567}$ Pouco depois, o bâtonnier relatou ao Conselho Federal que "vem mantendo contato com o Deputado José Bonifácio (...) que o informa do andamento dos Projetos de Lei de interesse da classe dos advogados". ${ }^{568}$ Ainda em 1959, José Bonifácio apresentou uma emenda ao orçamento da União em favor da OAB. ${ }^{569}$

Durante a $2^{\text {a }}$ Conferência Nacional da OAB, em agosto de 1960, Rui de Azevedo Sodré, dirigente da seção paulista da Ordem, exortou os presidentes das seccionais a pressionarem o Congresso Nacional para que fosse aprovado o novo estatuto da entidade:

\footnotetext{
${ }^{565}$ Ata de sessão do Conselho Federal, 11/10/1949 publicada no Jornal do Comércio, 20/10/1949, p. 2.

${ }^{566}$ CF-OAB, Ata de sessão do Conselho Federal, 13/7/1954.

${ }^{567}$ CF-OAB, Ata de sessão do Conselho Federal, 9/6/1959.

${ }^{568}$ CF-OAB, Ata de sessão do Conselho Federal, 21/7/1959.

${ }^{569}$ CF-OAB, Ata de sessão do Conselho Federal, 1/9/1959.
} 
"É preciso que nos compenetremos, todos nós, que, no momento, representamos a classe, que há necessidade, de um lado, exigirmos, não pelo sistema hoje adotado pelas classes trabalhadoras de conseguirem as leis que desejam pelas vias da ameaça, mas através de apelo aos legisladores, que, na verdade, são, em sua maioria, bacharéis em Direito, para que aprovem os nossos Estatutos. "570

Deste modo, Rui Sodré apelava para que a OAB aproveitasse a interlocução privilegiada de que gozava junto ao Legislativo, graças à importância da categoria profissional que controlava e à posição social de seus dirigentes. Todavia, o advogado paulista não reconhecia como legítima a mobilização dos trabalhadores, os quais reivindicavam seus interesses com os meios que a ausência daqueles atributos tornava possível.

Caberia, por fim, indagar-se sobre a capacidade do Conselho Federal de fazer valer sua posição junto ao Congresso Nacional. Nas escaramuças legislativas mais importantes em que se envolveu no período democrático - a lei da previdência dos advogados e o novo estatuto -, o Conselho Federal saiu-se vitorioso. Malgrado a longa tramitação no Congresso Nacional, o novo estatuto da OAB foi aprovado nos termos almejados pelo Conselho Federal. A comparação entre o projeto elaborado pela Ordem na década de 1950 e a redação do estatuto aprovado pelo Legislativo demonstra que o modelo e a regulamentação profissional propugnados pelo Conselho Federal, bem como a organização, a natureza jurídica e as atribuições da $\mathrm{OAB}$ planejadas pelo órgão foram preservadas no texto final.

\section{4.) A relação com o governo}

Quando sua ação junto ao Congresso Nacional falhava, restava ao Conselho Federal pleitear frente ao governo o veto presidencial. Assim, em agosto de 1950, o órgão recorreu a Dutra para impedir a entrada em vigor de um artigo de um projeto de

\footnotetext{
${ }^{570}$ Anais da $2^{a}$ Conferência Nacional da Ordem dos Advogados do Brasil, op. cit., p. 13.
} 
lei que permitia aos advogados exercerem seu ofício em qualquer parte do país, apresentando para tanto tão somente a carteira profissional. ${ }^{571}$ Ao receber, no Conselho Federal, o ministro da Justiça, o presidente da Ordem, Haroldo Valadão, lembrou-lhe o pedido feito a Dutra. ${ }^{572}$ Pouco depois, o Conselho Federal telegrafou ao presidente da República para expressar sua satisfação pelo veto ao artigo em questão. ${ }^{573}$ Noutra sessão, apresentando o relatório das atividades do Conselho Federal, em 1955, o secretário-geral mencionou o veto solicitado pelo órgão ao presidente Café Filho de um projeto de lei "altamente inconveniente à classe dos advogados. "574

O Conselho Federal também recorria ao governo federal para obter apoio material e recursos financeiros. Em 1948, o órgão entendeu-se com o ministro da Justiça para que o seu boletim fosse publicado pela Imprensa Oficial. ${ }^{575}$ Anos depois, frente à recusa deste órgão de imprimir o veículo de comunicação do Conselho Federal da $\mathrm{OAB}$, o secretário-geral Alberto Barreto de Melo invocou o direito da Ordem, já que ela se constituía um "serviço público federal", de se servir da Imprensa Oficial. Barreto de Melo informou ao Conselho Federal que, para fazer valer tal direito, recorreria ao ministro da Justiça. ${ }^{576}$

Quando a nova sede do Conselho Federal estava prestes a ser inaugurada, o presidente Atílio Vivacqua solicitou ao órgão autorização para pleitear, junto ao governo federal, recursos para as novas instalações. Argumentou que, dada " $a$ exiguidade de suas rendas", o Conselho Federal não tinha condições de garantir para si “instalações condignas”. Vivacqua lembrou que a sala de sessões usada pelo Conselho Federal (juntamente com a seção carioca da Ordem) fora provida com verba federal. A questão não suscitou qualquer polêmica e o Conselho Federal, unanimemente, aprovou a solicitação do bâtonnier. ${ }^{577}$ No ano seguinte, Atílio Vivacqua retomou o assunto, ao informar ao Conselho que pediria ao presidente Getúlio Vargas o envio de mensagem

\footnotetext{
${ }^{571}$ CF-OAB, Ata de sessão do Conselho Federal, 18/8/1950.

${ }^{572}$ CF-OAB, Ata de sessão do Conselho Federal, 22/8/1950.

${ }^{573}$ CF-OAB, Ata de sessão do Conselho Federal, 5/9/1950.

${ }^{574}$ CF-OAB, Ata de sessão do Conselho Federal, 3/4/1956.

${ }^{575}$ CF-OAB, Ata de sessão do Conselho Federal, 22/6/1948.

${ }^{576}$ CF-OAB, Ata de sessão do Conselho Federal, 16/9/1952.

${ }^{577}$ CF-OAB, Ata de sessão do Conselho Federal, 21/10/1952.
} 
ao Congresso Nacional solicitando a abertura de crédito especial destinado a financiar as novas instalações do órgão. ${ }^{578}$

No dia 22 de agosto de 1950, o Conselho Federal recebeu a visita do ministro da Justiça, Bias Fortes. Um dos mais destacados quadros do PSD mineiro, Fortes fora empossado no cargo havia menos de um mês. A visita ocorria às vésperas das eleições presidenciais e legislativas de outubro e numa conjuntura em que a OAB lutava contra o TCU para manter a sua autonomia. Discursando na ocasião, o ministro enalteceu a Ordem: "A Ordem dos Advogados do Brasil, que realiza a aspiração secular de uma nobre classe, a que tenho a honra de pertencer, constitui hoje um dos mais vigorosos esteios de um governo democrático. "579

No entanto, ao completar o argumento, Bias Fortes enfatizou a função exclusivamente corporativa que reconhecia na Ordem. Para ele, a responsabilidade da $\mathrm{OAB}$ na manutenção da democracia prendia-se estritamente à boa prática da advocacia e à defesa das prerrogativas da profissão, que garantiriam a boa distribuição da justiça. Ele nada falou sobre uma participação política ampla da $\mathrm{OAB}$, nos moldes que ela tivera no ano de 1945: "É que a função da Ordem dos Advogados do Brasil é manter sempre alertada a consciência profissional para o aperfeiçoamento desses requisitos na prática da advocacia, além de defender, custe o que custar, as prerrogativas da classe. "580 Delimitando o papel da OAB à seleção, fiscalização e defesa da categoria profissional, Bias Fortes recusava-lhe o papel de defensora da ordem jurídica. Ao invés de reconhecê-la como contra-poder ao Estado - papel pretendido pela sua cúpula -, o ministro exortava-a a colaborar com o governo:

"Exercitando, assim, vosso mister, Srs. Conselheiros, cooperais eficientemente com o governo digno de um povo livre, contribuindo para a equitativa distribuição de justiça, restabelecendo com moderação, porém, com

\footnotetext{
${ }^{578}$ CF-OAB, Ata de sessão do Conselho Federal, 14/4/1953.

${ }^{579}$ CF-OAB, Ata de sessão do Conselho Federal, 22/8/1950.

${ }^{580}$ CF-OAB, Ata de sessão do Conselho Federal, 22/8/1950.
} 
tenacidade, o equilíbrio nas relações sociais, facultando aos poderes constitucionais a pacífica administração da coisa pública. "581

Ao discursar logo após Bias Fortes, o presidente da OAB, Haroldo Valadão, fez uma profissão de fé em defesa de uma atuação mais abrangente da Ordem dos Advogados, voltada à proteção da ordem jurídica liberal, e de seu papel de contrapoder:

"E concluiu asseverando que a Ordem dos Advogados constitui, em verdade, a primeira linha no combate pela lei e pelo Direito, pela liberdade, tendo, pois, seu clima verdadeiro na democracia, em que tal luta é aberta, franca, facilitada. Mas que, mesmo na ditadura, soube, valorosamente, se impor ao arbítrio e à força, pugnando, sem recuos, por aqueles ideais, pela redemocratização do país. ${ }^{\prime 582}$

Se, de um lado, o entendimento sobre o papel a ser desempenhado pela Ordem afastava a entidade do governo, de outro, os interesses corporativos os aproximavam. Numa clara demonstração do governo de que pretendia estabelecer boas relações com o organismo, o ministro da Justiça listou os problemas que assaltavam a $\mathrm{OAB}$ naquele momento (a nova sede do Conselho Federal, o novo estatuto da Ordem, os honorários dos advogados, o ensino jurídico e o estágio profissional) e se comprometeu com a sua resolução:

"Tendes problemas a solucionar, desde o de vossa acomodação condigna até o da reforma de vossa lei constitucional."

“(...) Como Ministro da Justiça do Governo do Excelentíssimo Senhor General Eurico Gaspar Dutra, eu me ponho a vossa disposição, para colaborar

${ }^{581}$ CF-OAB, Ata de sessão do Conselho Federal, 22/8/1950.
${ }^{582}$ CF-OAB, Ata de sessão do Conselho Federal, 22/8/1950. 
convosco, dentro de minhas atribuições, para a consecução desses e de outros objetivos."

"Se me derdes essa oportunidade, alegrar-me-eis o coração, pois, lado a lado com a Ordem dos Advogados, estarei servindo ao Brasil. "583

Reverente aos poderes da República, o Conselho Federal, no entanto, considerava-se um obstáculo aos seus eventuais excessos. Ao assumir, em agosto de 1948, a secretaria-geral do Conselho Federal, posto que ocuparia até 1950, José Joaquim Marques Filho enfatizou a atuação corporativa da OAB. Porém, ressalvou que a Ordem não abria mão de seu papel de contra-poder ao Estado:

"(...) é certo que é de seu dever, nos momentos excepcionais de crise no Direito, manifestar-se, não acudindo, apenas, a interesses exclusivos da classe, senão, também a reclamos da Nação, sempre que a ordem jurídica for ofendida por excessos do poder (...) $)^{1584}$

Discursando no encerramento da $2^{\mathrm{a}}$ Conferência Nacional da OAB para uma plateia que compreendia não apenas a elite dos advogados, mas também a cúpula do Judiciário paulista e o governador de São Paulo, José Miramar da Ponte, membro da delegação cearense, reclamou aos advogados (e, por consequência, à $\mathrm{OAB}$ ) a atribuição de vigiar, para o bem da ordem jurídica liberal, os três poderes da República:

“Advogados que somos, não podemos subsistir em qualquer governo que assuma forma de opressão, nem mesmo em face do arbítrio exagerado do poder judiciário, ao qual prestamos o galardão público de nosso respeito, quando mantém o equilíbrio de sua atuação, orientado pelo conteúdo verdadeiro da Lei."

\footnotetext{
${ }^{583}$ CF-OAB, Ata de sessão do Conselho Federal, 22/8/1950.

${ }^{584}$ CF-OAB, Ata de sessão do Conselho Federal, 17/8/1948.
} 
"Respeitando, também, os poderes executivo e legislativo, como órgãos que são do princípio de autoridade, não renunciaremos jamais ao direito que nos assiste de fustigarmos qualquer afronta à ordem jurídica, seja imposta pela exacerbação do poder executivo, seja oriunda das inconsequências do poder legislativo, manifeste-se ainda, através do atentado ao Direito, infligido pelas sentenças incorretas, sob o aspecto formal, consideradas a sua constituição $e$ forma, ou pelas sentenças injustas pronunciadas contra a Lei, quanto ao seu conteúdo. ",585

As Conferências Nacionais da OAB reforçavam a pressão da sua cúpula sobre o Estado. Demonstrando força ao reunir algumas centenas de advogados de elite provenientes de todas as regiões do país e unificando sua posição em relação às questões corporativas, o Conselho Federal apresentava sua pauta de reivindicações às autoridades públicas, algumas delas presentes aos eventos. No seu discurso na abertura da $2^{\text {a }}$ Conferência Nacional, Alcino Salazar afirmou: "Sinto, assim, que os trabalhos desta Conferência (...) hão de produzir os melhores resultados e a voz autorizada dos juristas que aqui se reúnem há de ser ouvida pelos responsáveis pela direção dos negócios públicos. "586 Ao publicar os anais daquele encontro, a direção da seção paulista da Ordem anotou:

"Entregando à culta e brilhante classe dos bacharéis em ciências jurídicas e sociais os Anais da $2^{a}$ Conferência (...) tem o Conselho Seccional de São Paulo a esperança de que os temas nela debatidos e as conclusões adotadas sejam objeto de meditação e acolhimento por parte de todos quantos tenham uma parcela de responsabilidade na delicada função de distribuição de Justiça em nosso País, quer no exercício da profissão, quer no desempenho de mandato legislativo, quer

\footnotetext{
${ }^{585}$ Anais da $2^{a}$ Conferência Nacional da Ordem dos Advogados do Brasil, op. cit., p. 319.

${ }^{586}$ Ibidem, p. 35.
} 
em função judicante, ou mesmo em qualquer outro setor de atividades públicas ou privadas. ",587

Ao mesmo tempo, as Conferências Nacionais visavam o estreitamento das relações da cúpula da $\mathrm{OAB}$ com o Estado. $\mathrm{Na} 1^{\text {a }}$ Conferência, estiveram presentes o ministro da Justiça, Cirilo Júnior, o presidente do STF, Orozimbo Nonato, o presidente do Tribunal Federal de Recursos, Artur Marinho, e o do Tribunal Superior do Trabalho, Júlio Barata. ${ }^{588}$ À $2^{\text {a }}$ Conferência, realizada em São Paulo, compareceram o governador do estado, Carvalho Pinto, e seu secretário de Justiça, além dos presidentes do Tribunal de Justiça e do Tribunal de Alçada de São Paulo. ${ }^{589}$ O regimento da $1^{\text {a }}$ Conferência, no parágrafo terceiro do artigo 15, reverenciava a intenção de aproximação do Conselho Federal em relação ao Estado, prevendo que as sessões solenes do encontro poderiam ser dirigidas pela "autoridade mais graduada presente".

No período democrático, o Conselho Federal esteve especialmente próximo de um presidente da República. Juscelino Kubitschek visitou a sede do órgão e referendou, nesta ocasião, o projeto de novo estatuto da OAB. Seu ministro da Justiça, Cirilo Júnior, recebeu, às vésperas da realização da $1^{\mathrm{a}}$ Conferência Nacional da $\mathrm{OAB}$, o bâtonnier Nehemias Gueiros. No encontro, Gueiros solicitou a liberação de recursos orçamentários destinados à Ordem dos Advogados. Gueiros narrou ao Conselho Federal ter sido recebido "com a maior fidalguia" pelo ministro, que tomou, segundo o presidente, providências para a imediata liberação da verba. Nesta mesma ocasião, o presidente da OAB convidou Cirilo Júnior para presidir a abertura da conferência - o que foi aceito pelo ministro - e pediu-lhe que transmitisse a Juscelino Kubitschek o convite para presidir o encerramento do evento. ${ }^{590}$ No entanto, esta proximidade com o governo Kubitschek sofreu a oposição de, ao menos, um membro do Conselho Federal. Depois que o bâtonnier Nehemias Gueiros informou que convidara Kubitschek para presidir o encerramento da $1^{\text {a }}$ Conferência, o conselheiro federal Luís Mendes de

\footnotetext{
${ }^{587}$ Ibidem, p. 4.

${ }^{588}$ Anais da $1^{a}$ Conferência Nacional da Ordem dos Advogados do Brasil, op. cit., p. 5 e 546.

${ }^{589}$ Anais da $2^{a}$ Conferência Nacional da Ordem dos Advogados do Brasil, op. cit., p. 21 e 318.

${ }^{590}$ CF-OAB, Ata de sessão do Conselho Federal, 15/7/1958.
} 
Morais Neto escreveu-lhe uma carta na qual manifestava o seu desacordo em relação ao convite: “(...) só aceito no Conselho Federal, como presidente, quem possua competência legal para exercer o mister (...)". 591 Talvez em virtude deste incidente, o dispositivo que possibilitava a uma autoridade pública presidir sessões nos encontros foi suprimido no regimento da $2^{\text {a }}$ Conferência Nacional. ${ }^{592}$ Em 1956, Morais Neto já manifestara sua desaprovação ao fato de que o presidente da República dirigira a sessão do Conselho Federal em que Gueiros fora empossado. ${ }^{593} \mathrm{Na}$ abertura da $1^{\text {a }}$ Conferência Nacional da $\mathrm{OAB}$, Gueiros chegou a anunciar que o encerramento do encontro seria realizado por Juscelino Kubitschek. ${ }^{594}$ Entretanto, o presidente da República não compareceu à cerimônia. Dias depois, o chefe da Casa Civil, Victor Nunes Leal, visitou o Conselho Federal para "trazer as congratulações" de Kubitschek à diretoria recémempossada, bem como expressar sua disposição de colaborar com a Ordem. ${ }^{595}$

\footnotetext{
${ }^{591}$ Diário de Notícias, 3/8/1956, 1a $1^{\text {a }}$ eção, p. 2.

${ }^{592}$ CF-OAB, Ata de sessão do Conselho Federal, 7/6/1960.

${ }^{593}$ Diário de Notícias, 3/8/1956, $1^{\text {a }}$ seção, p. 2. No final de 1959, o conselheiro federal Luís Mendes de Morais Neto foi preso como um dos líderes da Revolta de Aragarças. Na sessão de 15 de dezembro, o presidente Alcino Salazar comunicou ao Conselho Federal que, assim que soubera da prisão de Morais Neto, procurara seu pai, Justo de Morais, para obter notícias. Na mesma sessão, ainda que sem defender a conspiração contra Juscelino Kubitschek na qual Morais Neto se envolvera, o conselheiro federal MacDowell da Costa propôs que o Conselho Federal "lhe dê toda a assistência profissional de que venha a necessitar e bem assim lhe leve, oportunamente, a expressão de nossa amizade e conforto moral." Por sua vez, Alcino Salazar elogiou a atuação, no Conselho Federal, do preso. O Conselho da Ordem do Distrito Federal incumbiu o célebre advogado de presos políticos Evandro Lins e Silva da defesa de Morais Neto, que, depois de libertado, voltou ao Conselho Federal, como integrante da delegação da Guanabara. CFOAB, Ata de sessão do Conselho Federal, 15/12/1959; SILVA, Evandro Lins e. O salão dos passos perdidos: depoimento ao CPDOC. Rio de Janeiro: Nova Fronteira/Editora FGV, 1997, p. 306-307.

${ }_{594}$ Anais da $1^{a}$ Conferência Nacional da Ordem dos Advogados do Brasil, op. cit., p. 8.

${ }^{595}$ CF-OAB, Ata de sessão do Conselho Federal, 19/8/1958.
} 


\section{CAPÍtulo VII: A RELAÇÃo Do CONSELHO FEDERAL COM A CATEGORIA PROFISSIONAL}

\section{1.) A adesão dos advogados às posições do Conselho Federal}

Até que ponto o conjunto dos advogados brasileiros se identificava com as posições tomadas pelo Conselho Federal da $\mathrm{OAB}$ a respeito da política nacional? Procurar-se-á responder a esta indagação acompanhando-se a atitude dos advogados e, sobretudo, de suas outras organizações profissionais em duas conjunturas de especial participação política da categoria: o fim do Estado Novo e o governo Goulart.

Como já se disse, o Conselho Federal da OAB contou com o apoio de seções estaduais importantes e de outras entidades de advogados nas suas iniciativas contra o Estado Novo. Ademais, duas entidades de advogados que tinham relevante projeção pública, a seção do Distrito Federal da OAB, presidida por Pinto Lima, e o secular IAB, dirigido por Haroldo Valadão, estavam inteiramente alinhadas ao oposicionismo do Conselho Federal. Haroldo Valadão, ao assumir a presidência do Instituto, em abril de 1945, não deixou dúvidas quanto ao posicionamento político que imprimiria à entidade:

“(...) é urgente a reconstitucionalização do Brasil, devastado há mais de sete anos, desde 10 de novembro de 1937, por um regime de arbítrio pessoal e feição totalitária que violentou a consciência jurídica nacional do Brasil, ansiosa de retomar o rumo secular de suas tradições de democracia e de liberdade. ",596

Em algumas ocasiões, os bacharéis liberais instalados na cúpula da OAB deram provas cabais da adesão com que suas atitudes contavam no conjunto da categoria profissional. Destaque-se o pedido de habeas corpus em favor de líderes oposicionistas assinado por mais de quinhentos advogados e, sobretudo, o manifesto de apoio à candidatura de Eduardo Gomes que teve, pelo menos, mil advogados como signatários.

\footnotetext{
${ }^{596}$ FAGUNDES, Laura, op. cit., p. 200.
} 
Não é demais repetir que o país tinha, então, não mais de quinze mil advogados, dos quais um terço militava no Distrito Federal. Estes exemplos mostram que o apoio ao oposicionismo do Conselho Federal sustentava-se não apenas na elite, mas também em outros estratos da categoria profissional. É bem verdade, contudo, que estas manifestações tiveram a participação praticamente exclusiva de advogados cariocas. Por outro lado, a contestação surgida no interior da categoria profissional à atuação política do Conselho Federal, especialmente em 1945, emergiu de setores francamente minoritários, vinculados ao queremismo e à esquerda.

Outras entidades de advogados deram combate ao governo Goulart com os mesmos argumentos do Conselho Federal da OAB, justificando sua atitude em nome da preservação da institucionalidade estabelecida pela Constituição de 1946, que consideravam ameaçada pelo governo federal. No dia 26 de março de 1964, o Instituto dos Advogados de São Paulo divulgou um manifesto em defesa do direito de propriedade, que estaria ameaçado pelo governo federal. ${ }^{597}$ Dois dias antes, o IAB aprovou por unanimidade uma indicação de Heráclito Sobral Pinto clamando pela intervenção das Forças Armadas contra as Reformas de Base:

“(...) o Instituto dos Advogados Brasileiros repele, com firmeza, o uso da violência e a pregação da subversão como meio de promover a reforma da estrutura social estabelecida e fixada na Constituição Federal. Alimenta, assim, a esperança de que todos os brasileiros, especialmente as Forças Armadas, fiéis à definição legal, que lhes impõe o dever de 'defender a Pátria (...) e garantir os Poderes Constitucionais, a lei e a ordem, não permitirão que elementos subversivos e de desagregação social se aglutinem impunemente para perturbar o livre funcionamento do Congresso Nacional, a autonomia dos Estados e todas as liberdades públicas, ora gravemente ameaçadas em nossa terra. "598

\footnotetext{
${ }^{597}$ SAES, Décio. Classe média e política no Brasil, 1930-1964. In: FAUSTO, Boris (direção). História Geral da Civilização Brasileira. Rio de Janeiro: Bertrand Brasil, 1996, tomo 3, volume 3, p. 502.

${ }^{598}$ FAGUNDES, Laura, op. cit., p. 229-230.
} 
Na mesma sessão, o IAB recusou-se a aprovar uma moção de Teófilo Azeredo Santos que propunha o apoio do Instituto às reformas propugnadas pelo presidente da República, "desde que dentro da tradição cristã, social e constitucional." ocorria apenas alguns dias após o Conselho Federal da OAB derrotar uma proposição semelhante elaborada pelo conselheiro Paulo Belo, como mencionado anteriormente.

Finalmente, no dia 31 de março, a Associação dos Advogados Democratas lançou um documento, assinado por mil advogados, contra a "violação da Constituição" e a "ingerência do Executivo federal nos demais poderes da República."600 O número de signatários é significativo, considerando-se que o contingente de advogados no país, neste momento, girava em torno dos trinta mil. Sabese que a mesma associação fora uma das organizadoras da Marcha da Família com Deus pela Liberdade, uma das manifestações de rua que ofereceram apoio à deposição de Goulart, realizada em São Paulo, no dia 19 de março de $1964 .{ }^{601}$ Ainda em 1962, o IPES encomendara à Associação dos Advogados Democratas um estudo sobre os aspectos jurídicos do parlamentarismo e do presidencialismo. ${ }^{602}$

No início de abril de 1964, a Associação Carioca de Advogados Trabalhistas (ACAT) divulgou um documento no qual apoiava o golpe civil-militar e exortava o governo a intensificar a perseguição aos inimigos da nova ordem. É mesmo surpreendente que o documento negligencie alguns dogmas liberais caros aos advogados, como o império da lei e as liberdades individuais:

"A Associação Carioca de Advogados Trabalhistas (ACAT), pelo seu Conselho Deliberativo reunido em sessão extraordinária (...) resolveu: 1) Manifestar seu regozijo pelo êxito alcançado pelo movimento revolucionário de $1^{o}$ de abril; (...) 4) Exigir que providências enérgicas sejam tomadas visando a

\footnotetext{
${ }^{599}$ Ibidem, p. 230.

${ }^{600}$ SAES, Décio, op. cit., p. 502.

${ }^{601}$ ALMEIDA, Cristiane Rodrigues Soares. O Governo João Goulart nas páginas da Folha de S. Paulo. Uberlândia, 2008. Dissertação (Mestrado em História). Universidade Federal de Uberlândia, p. 136.

${ }^{602}$ RAMÍREZ, Hernán Ramiro. Os institutos de estudos econômicos de organizações empresariais e sua relação com o Estado em perspectiva comparada: Argentina e Brasil, 1961-1996. Porto Alegre, 2005. Tese (Doutorado em História). UFRS, p. 315.
} 
neutralizar a ação dos agentes comunistas, que infiltrados em todos os setores da vida pública brasileira, inclusive no Poder Judiciário, e especialmente na Justiça do Trabalho, vêm se prevalecendo das liberdades democráticas que a Constituição assegura a todos os cidadãos, para destruí-la; 5.) Lembrar aos ilustres chefes militares que não podem se quedar diante de filigranas jurídicas levantadas por aparentes cultores do Direito (...) que pretendem resguardar posições incompatíveis com a vida democrática, não merecendo a proteção da lei quem não a reverenciou; (...) 7) Nenhum Direito individual pode sobrepor-se, nesta hora, à segurança das instituições democráticas que exigem vigília e ação. ",603

Ainda que não se tenham informações sobre a representatividade da ACAT entre os advogados trabalhistas do Rio de Janeiro, é interessante constatar que mesmo neste setor profissional, locus privilegiado de atuação de advogados esquerdistas, havia uma entidade dirigida por advogados conservadores e plenamente alinhada à coalizão golpista.

Várias seções estaduais da OAB também manifestaram seu apoio ao novo regime. A seção pernambucana, por exemplo, em 16 de abril de 1964, enviou a Castelo Branco um telegrama no qual aplaudia o discurso que este proferira ao assumir a presidência da República. ${ }^{604}$

A literatura que se dedicou à análise do comportamento político das classes médias, das quais os advogados eram componentes ilustres e politicamente ativos, contribui para a compreensão da significativa adesão obtida, no seio da categoria profissional, pelo liberalismo conservador professado pelo Conselho Federal da OAB.

Segundo Paulo Sérgio Pinheiro, na Primeira República, a ação política das classes médias estava a reboque das classes dominantes, destacadamente dos grandes proprietários rurais. $\mathrm{O}$ autor, porém, admite o engajamento das classes médias em movimentos de contestação ao poder, o que ocorreu quando as classes médias se

${ }^{603}$ Correio da Manhã, 8/4/1964, $1^{\circ}$ caderno, p. 5.

${ }^{604}$ COELHO, Fernando, op. cit., p. 50. 
aliaram a frações não-hegemônicas das classes dominantes. ${ }^{605} \mathrm{O}$ empreguismo era um instrumento poderoso para atrelar as classes médias às dominantes. Ao oferecerem emprego público às classes médias, as classes dominantes reforçavam o vínculo de dependência das primeiras em relação a si. ${ }^{606}$ Pode-se supor que os advogados fossem sensíveis a este padrão de dominação. Muitos bacharéis em Direito eram funcionários públicos e advogavam nas horas vagas. Mesmo aqueles que se direcionavam para as carreiras jurídicas não podiam fugir da mediação das classes dominantes. $\mathrm{O}$ acesso a estas carreiras e o sistema de promoções que nelas vigorava ainda dependiam fortemente de apadrinhamentos e conhecimentos políticos. Com relação aos advogados que eram estritamente profissionais liberais, ou seja, que desempenhavam seu ofício tão somente nos seus escritórios, sabe-se que os proprietários rurais e os grandes comerciantes formavam uma valiosa clientela. Havia, certamente, os advogados que constituíram sua clientela entre as classes médias. No entanto, não há qualquer evidência de que estes advogados - economicamente independentes das classes dominantes - tenham se aproximado politicamente das classes populares. Paulo Sérgio Pinheiro propõe que as classes médias professavam o mesmo liberalismo excludente das classes dominantes, cuja concepção a respeito do governo era a de que o seu exercício deveria ser apanágio de homens cultos. Desta forma, as classes médias sentiam-se contempladas por esta concepção elitista pois, como tinham acesso ao ensino superior, podiam chegar aos postos de comando do Estado. ${ }^{607}$ Ora, o elitismo das classes médias transfigurava-se no bacharelismo. A eleição do diploma superior como precondição para o exercício das altas funções públicas legitimava o exercício excludente do poder. ${ }^{608}$ Os componentes fundamentais da ideologia das classes médias, na Primeira

\footnotetext{
${ }^{605}$ PINHEIRO, Paulo Sérgio. Classes médias urbanas: formação, natureza, intervenção na vida política. In: FAUSTO, Boris (direção). História Geral da Civilização Brasileira. Rio de Janeiro: Bertrand Brasil, 1997, tomo 3, volume 2, p. 35-36.

${ }^{606}$ Ibidem, p. 20.

${ }^{607}$ Ibidem, p. 33, 36-37.

608 "No aspecto-mito da passarela, isto é, no fato de as classes médias aspirarem sempre a se tornarem burguesia, pela passagem individual para o alto dos 'melhores' e dos 'mais capazes', está o elitismo, que assume a forma própria do bacharelismo. Através dele as classes médias defendem sua posição acima do proletariado, graças à sua passagem pelos circuitos da educação, conferida pelo aparelho escolar e pelo acesso à 'cultura', facilitado pelas relações familiares. Até que ponto essa ênfase na validação social via
} 
República, eram o civilismo, o elitismo, o agrarismo, o antiindustrialismo e o antiintervencionismo, afirma Paulo Sérgio Pinheiro. ${ }^{609}$

Francisco Weffort destaca a principalidade da ação contestatória das classes médias na Primeira República. Contudo, o programa destes setores limitava-se à exigência do cumprimento de dispositivos de natureza liberal-democrática já previstos pelas normas legais do regime oligárquico, como o voto secreto e universal, mas não contemplava propostas de transformação das estruturas sócio-econômicas. Ainda assim, a mobilização das classes médias foi um elemento central da crise que marcou o declínio da hegemonia política do latifúndio e a emergência do Estado de Compromisso, a partir de $1930 .{ }^{610}$ A possibilidade aberta pela Revolução de 1930 para que as classes médias reorganizassem o Estado segundo seus princípios e interesses frustou-se pela sua dependência econômica em relação à grande propriedade. Aliás, este é um aspecto importante na análise de Weffort. Segundo o autor, a orientação da economia brasileira para a exportação impediu que as classes médias desenvolvessem atividades econômicas autônomas e, consequentemente, tivessem condições de uma atuação política igualmente autônoma. ${ }^{611}$

Boris Fausto, concordando com a interpretação de Francisco Weffort, admite que o comportamento dominante das classes médias na década de 1920 era de adesão aos princípios liberais e marcado pela dependência social e ideológica em relação ao núcleo agrário-exportador. ${ }^{612}$ No entanto, Boris Fausto sugere a existência de um setor

educação não seria um elemento próprio da ideologia das classes médias na Primeira República? Poderíamos observar nesse sentido que essa validação principalmente fornecida pelas faculdades de Direito, poderoso elemento de reprodução estrutural e da consolidação do aparelho de Estado, serve para reforçar a ligação das classes médias à manutenção do status quo. Caberia ainda ver de que maneira se entrosam e se complementam os mecanismos do 'coronelismo', que assume um papel primordial como articulação principal dos controles sociais e políticos exercidos pelas classes dominantes tradicionais, $e$ do 'bacharelismo' - a mitificação em torno da formação obtida nas faculdades. Essa complementação vai ocorrer na burocracia, à qual esses bacharéis terão acesso, mas à qual raramente serão capazes de desenvolverem um projeto próprio. " PINHEIRO, Paulo Sérgio, op. cit., p. 33-34.

${ }^{609}$ Ibidem, p. 33.

${ }^{610}$ WEFFORT, Francisco. O populismo na política brasileira. Rio de Janeiro: Paz e Terra, 1978, p. 115118.

${ }^{611}$ Ibidem, p. 115-119.

${ }^{612}$ FAUSTO, Boris. A revolução de 1930: historiografia e história. São Paulo: Companhia das Letras, 1997, p. 93, 108-110. 
minoritário das classes médias alinhado a um projeto de salvação nacional contra as oligarquias a ser conduzido pelos militares. ${ }^{613}$ Tal segmento emprestou seu apoio ao tenentismo na década de 1920. É verdade que, neste período, o inconformismo com o domínio oligárquico marcou a atuação política das classes médias, que, contudo, não aderiram a propostas de transformação radical da ordem vigente - interpretação que partilha com Weffort. O descontentamento político das classes médias aproximou-as dos setores dissidentes das oligarquias. Seu horizonte político era a realização plena da democracia liberal (o que incluía o voto secreto, a representação das minorias e a independência do Judiciário) por meio da reforma política - o que era contemplado pelo programa da Aliança Liberal. As classes médias, sobretudo as de São Paulo e do Distrito Federal, tiveram participação importante na Revolução de 1930 - ainda que dela tenham participado numa situação subordinada. ${ }^{614}$ Na década de 1930, prossegue Fausto, o maior contingente das classes médias permaneceu fiel ao projeto de democracia liberal - o que explica sua adesão à Revolução Constitucionalista, em 1932. ${ }^{615}$ De todo modo, neste momento, segundo hipótese levantada pelo autor, o segmento minoritário das classes médias que, até então, emprestavam seu apoio ao salvacionismo militar dividiu-se politicamente, cedendo tanto adeptos à Aliança Nacional Libertadora (ANL) quanto à Ação Integralista Brasileira (AIB).

Octavio Ianni relaciona a importância da participação política das classes médias no período democrático ao seu crescimento numérico, processo ocorrido em função do aumento de postos de trabalho no comércio, no setor de serviços e no aparelho estatal, incentivado pela urbanização e industrialização. ${ }^{616}$ Ianni propõe que o universo cultural e mental das classes médias estava impregnado dos valores das classes dominantes e que, portanto o seu comportamento político encontrava-se condicionado pelo seu projeto de ascensão social. Assim, os setores médios demonstraram-se particularmente inclinados, em 1964, a uma solução autoritária, considerada um eficaz antídoto ao risco

\footnotetext{
${ }^{613}$ Ibidem, p. 93.

${ }^{614}$ Ibidem, p. 93, 99, 104, 108-110.

${ }^{615}$ Ibidem, p. 93, 99, 109-110.

${ }^{616}$ IANNI, Octavio. O colapso do populismo no Brasil. Rio de Janeiro: Civilização Brasileira, 1968, p. 139.
} 
de proletarização (causada pela inflação e pelo aumento dos salários do operariado) que ameaçavam amplos segmentos destas classes. ${ }^{617}$

Ao sintetizar a atuação política da alta classe média (onde inclui os profissionais liberais) durante o período republicano, Décio Saes a considera aliada dos interesses da burguesia comercial. De acordo com o autor, na Primeira República, a alta classe média teria atuado no sentido de reforçar a hegemonia da burguesia comercial no interior das classes dominantes. A partir de 1930, teria sido instrumento da mesma fração da burguesia na tentativa de reconquista do Estado. Assim, a alta classe média, segundo Saes, constituiu a base de apoio dos partidos políticos liberais que expressaram, de 1930 a 1964, os “interesses agroexportadores”: o Partido Democrático, o Partido Constitucionalista, a União Democrática Brasileira (UDB) e a UDN. Igualmente, a alta classe média forneceu o apoio social necessário às tentativas da burguesia comercial de voltar à direção do Estado pelas armas (como em 1932 e 1954). ${ }^{618}$ Saes destaca o papel desempenhado pelos profissionais liberais, notadamente pelos advogados, nas tentativas de "restauração liberal”, em 1932, 1934, 1945 e $1954{ }^{619}$ Ideologicamente, a camada superior das classes médias adotou, durante o período republicano, um liberalismo de viés elitista. Décio Saes descreve os componentes do ideário da alta classe média de modo praticamente idêntico ao que faz Paulo Sérgio Pinheiro para o conjunto dos setores médios: agrarismo, antiindustrialismo, antiintervencionismo e elitismo. ${ }^{620}$

Mas quais são, para Décio Saes, os móveis da dependência dos profissionais liberais em relação à burguesia comercial? Em primeiro lugar, o autor aponta a persistência da capacidade de direção política desta fração burguesa mesmo depois de apeada do poder, em 1930. Em segundo lugar, destaca a "situação de trabalho" dos profissionais liberais, marcada, por um lado, pela autonomia profissional e, por outro, pela existência de corporações profissionais. Os profissionais liberais gozavam de autonomia para tomar decisões e organizar suas condições de trabalho. A independência

\footnotetext{
${ }^{617}$ Ibidem, p. 139-140.

${ }^{618}$ SAES, Décio. Classe média e política no Brasil, 1930-1964. In: FAUSTO, Boris (direção). História Geral da Civilização Brasileira. Rio de Janeiro: Bertrand Brasil, 1996, tomo 3, volume 3, p. 454 e 463.

${ }^{619}$ Ibidem, p. 466-467.

${ }^{620}$ Ibidem, p. 463.
} 
profissional era protegida pela apologia da liberdade de mercado e pela recusa do intervencionismo estatal. Assim, a defesa das suas específicas condições de trabalho estaria na origem de sua crença no liberalismo econômico. ${ }^{621}$ Além disto, Saes associa a seleção profissional praticada pelas corporações (intrinsecamente excludente) ao elitismo político dos profissionais liberais, assentado na defesa da participação política restrita às "elites culturais.",622

Finalmente, Décio Saes aponta o surgimento de uma nova alta classe média, em meados da década de 1950, dedicada ao comando da empresa capitalista. Este setor nasceu a partir das transformações operadas no capitalismo brasileiro, com a afirmação da grande indústria "moderna" e monopolista, a produção de bens de consumo duráveis e de insumos industriais e o desenvolvimento do capital financeiro. $\mathrm{O}$ autor explica que este novo setor da alta classe média experimentava uma nova situação de trabalho, em que o desempenho da autoridade técnica e administrativa no interior da grande empresa capitalista favorecia a crença na natureza racional da autoridade e no imperativo de uma organização autoritária e hierarquizada da sociedade. Deste modo, o setor moderno afastava-se do liberalismo do setor tradicional da alta classe média, aderindo a um estatismo autoritário. ${ }^{623}$ Não à toa, prossegue o autor, que esta fração constituiu-se em base de apoio da ditadura militar, a partir de $1964 .{ }^{624}$

Deve-se acrescentar que uma parte desta nova alta classe média era formada de elementos egressos da alta classe média tradicional. Entre eles, encontravam-se profissionais liberais transformados em empregados de empresas. Com o apoio do já mencionado estudo de Olavo Brasil, Lúcia Klein e Antônio Martins é possível notar que os advogados recrutados por empresas tinham sua situação de trabalho profundamente

\footnotetext{
${ }^{621}$ Ibidem, p. 465.

${ }^{622}$ Ibidem, p. 466.

${ }^{623}$ Ibidem, p. 505.

${ }^{624}$ No início dos anos 60, a frente das forças liberais (capital comercial em geral, burguesia cafeeira, alta classe média tradicional) está condenada à decadência política; todavia, o seu arcaísmo tem um papel a desempenhar, na organização de um movimento contra-revolucionário de 'massa'. Na crise politica de 1964, as formas acabadas (comícios anti-governamentais, campanhas cívicas, 'movimento feminino', corporações de profissionais liberais) chamam a nossa atenção para a antiga classe média, $e$ nos impedem de captar a tendência autoritária 'difusa' da nova classe média. A rigor, a presença política dessa nova fração só se torna evidente após o golpe de Estado de 1964, quando tende a se constituir na reduzida base social de apoio do regime militar." SAES, Décio, op. cit., p. 505.
} 
modificada, não apenas em função do vínculo de emprego que os subordinava a um patrão, mas também porque suas atividades adquiriam contornos de um trabalho técnico. Deve-se supor que estes advogados, engajados num ambiente de trabalho tecnocrático, tendiam a trocar os valores liberais que historicamente caracterizaram sua categoria profissional pelo ideário estatista-autoritário proposto por Décio Saes. Deste modo, ainda que o liberalismo tenha se mantido dominante entre os advogados no período democrático ${ }^{625}$, é preciso reconhecer que o processo de diferenciação política que Boris Fausto identifica para o conjunto das classes médias também os abarcou. Contribuíram para isto a expansão do ensino do Direito, a universalidade, em termos de origem social, do recrutamento para a profissão, o processo de assalariamento e a afirmação, à esquerda e à direita, de projetos políticos alternativos à democracia liberal.

Um ramo do Direito acolheu, de modo especial, os advogados que se distanciavam do credo liberal: comunistas, socialistas, trabalhistas e católicos. Tratavase do Direito do Trabalho, que se estruturou a partir do primeiro governo Vargas. É verdade que a elite dos advogados a considerava um ramo de menor importância e prestígio. Porém, ele atraiu mesmo advogados egressos de faculdades de Direito tradicionais, como a da Universidade de São Paulo (USP). Alguns advogados trabalhistas alcançaram significativa projeção política no período democrático. Eles eram empregados de sindicatos de trabalhadores ou atendiam a estes nos seus escritórios de advocacia. O seu trabalho os levava a travar conhecimento com as lideranças operárias e, frequentemente, a desempenhar funções em greves e negociações com os patrões. Em meados da década de 1940, o Partido Comunista Brasileiro (PCB) manteve um departamento jurídico na cidade de São Paulo, que tinha, entre suas atribuições, a de impetrar pedidos de habeas corpus em favor de trabalhadores, sindicalistas e membros do partido. Rio Branco Paranhos era talvez o mais célebre dentre os advogados trabalhistas vinculados ao PCB atuantes em São Paulo. Nascido em 1913, foi candidato a deputado estadual pelo PCB. Trabalhou no departamento jurídico do partido e, em

\footnotetext{
${ }^{625}$ Em sua pesquisa empírica, Olavo Brasil, Lúcia Klein e Antônio Martins constatam a permanência da adesão majoritária dos advogados ao liberalismo político. LIMA JÚNIOR., Olavo Brasil de; KLEIN, Lúcia Maria Gomes; MARTINS, Antônio Soares, op. cit., p. 51-52. Faço esta referência sem prejuízo à ressalva que fiz anteriormente sobre a amostragem de entrevistados usada pelos autores.
} 
1946, acolheu em sua casa Anita Prestes, filha de Luís Carlos Prestes e Olga Benário. Em 1949, passou a advogar para o Sindicato dos Trabalhadores Têxteis de São Paulo. Além disto, mantinha um importante escritório de advocacia trabalhista na capital paulista. ${ }^{626}$

Católicos também ingressaram na advocacia trabalhista. É preciso lembrar que um dos pioneiros do Direito do Trabalho no Brasil foi Antônio Cesarino Júnior, líder católico, professor de Direito do Trabalho na USP e fundador do Partido Democrata Cristão (PDC). Cesarino Júnior formou as primeiras gerações de advogados e juízes trabalhistas em São Paulo. ${ }^{627}$ Cito dois exemplos de advogados católicos que, depois de formados na Faculdade de Direito da USP no período em que Cesarino Júnior era professor, atuaram na área trabalhista: Mario Carvalho de Jesus e Teófilo Ribeiro de Andrade Filho. Mario Carvalho de Jesus nasceu em 1919 e bacharelou-se em 1947. No início da década de 1950, foi advogado do Sindicato dos Metalúrgicos de São Paulo. Depois, advogou para o Sindicato dos Trabalhadores nas Indústrias Cimenteiras. Atuou como advogado do sindicato dos trabalhadores da Fábrica de Cimento de Perus, na cidade de São Paulo. Nesta condição, foi, segundo o juízo de Elcio Siqueira, a principal liderança da célebre greve sustentada por estes trabalhadores, entre 1962 e 1963. Nas décadas de 1950 e 1960, Mário Carvalho de Jesus foi um dos dirigentes de uma corrente sindical operária de cunho democrata-cristão que se agrupava em torno da Frente Nacional do Trabalho (FNT). ${ }^{628}$

Teófilo Andrade, nascido em 1922, foi, na década de 1940, companheiro de Mario Carvalho de Jesus no grupo de militantes da Juventude Universitária Católica (JUC) atuante na Faculdade de Direito da USP. Sua família tinha tradição política e seu pai foi deputado estadual, em São Paulo, na Primeira República. Formado, advogou para o Sindicato dos Metalúrgicos de São Paulo. Dirigente do PDC em São Paulo,

\footnotetext{
${ }^{626}$ CORRÊA, Larissa Rosa. Trabalhadores têxteis e metalúrgicos a caminho da Justiça do Trabalho: leis e Direitos na cidade de São Paulo - 1953 a 1964. Campinas, 2007. Dissertação (Mestrado em História). UNICAMP, p. 33-41.

${ }^{627}$ SIQUEIRA, Elcio. Melhores que o patrão: a luta pela cogestão operária na Companhia Brasileira de Cimento Portland Perus (1958-1963). Campinas, 2009. Tese (Doutorado em História). UNICAMP, p. 132.

${ }^{628}$ Ibidem, p. 15-19, 35, 41-42, 154-155, 164
} 
elegeu-se deputado federal em 1962. Teófilo Andrade foi membro da elite dirigente dos advogados paulistas, pois foi conselheiro da Associação dos Advogados de São Paulo (AASP ), entre 1959 e 1961, e da seção paulista da OAB. ${ }^{629}$

\section{2.) A incorporação da função sindical}

A relação do Conselho Federal da $\mathrm{OAB}$ com a categoria profissional foi marcada, no período democrático, por um profundo distanciamento. Nos momentos de mobilização política, o órgão assumiu uma postura iluminista, incumbindo-se de mostrar aos advogados o caminho a ser seguido. No campo corporativo, o Conselho Federal atuou, primordialmente, como um centro disciplinador, que procurava, pela exaltação aos "grandes advogados" e pela punição, conformar o conjunto dos advogados a seu ideário profissional. De fato, destacava-se a ação selecionadora e, sobretudo, disciplinadora do organismo. Boa parte de suas sessões era despendida com a análise de incompatibilidades no exercício da advocacia e o exame de infrações ao Código de Ética e ao Estatuto da OAB. Adepto da democracia representativa, o Conselho Federal entendia que sua relação com a categoria profissional deveria ser feita pela mediação das seções e subseções da OAB.

A irregularidade dos boletins editados pelo Conselho Federal demonstra a pouca disposição da cúpula da $\mathrm{OAB}$ em manter um canal de interlocução direta com os advogados. ${ }^{630}$ Os boletins não se prestavam a ser uma tribuna de debates ou um meio de auscultação das demandas da categoria profissional, antes funcionando como um diário oficial do Conselho Federal, publicizando as ações e decisões do organismo. As suas páginas eram preenchidas pelas atas e relatórios de atividades do Conselho Federal, ementas de processos disciplinares, documentos elaborados pelas seções estaduais e resultados de eleições para as diretorias das seccionais. Em alguns números, havia notícias sobre iniciativas do Conselho Federal, relacionadas, por exemplo, ao novo

\footnotetext{
${ }^{629}$ SIQUEIRA, Elcio, op. cit., p. 266 e 271; ANDRADE, Teófilo. In: ABREU, Alzira Alves de et alli. (coord.), op. cit; <http://www2.camara.gov.br $>$. Acesso em 30/12/2009.

${ }^{630} \mathrm{Em}$ consulta às bibliotecas do IAB, da OAB paulista e do Conselho Federal da Ordem, localizei seis boletins editados pelo Conselho Federal no período democrático - todos listados no final deste trabalho. Nas atas de sessões do órgão, há referências esparsas sobre os boletins. No entanto, não há nelas qualquer evidência de que o Conselho Federal tenha publicado outros boletins neste período.
} 
estatuto da $\mathrm{OAB}$ ou à previdência social dos advogados. Assim, Nehemias Gueiros, no boletim de novembro de 1957 , noticiava a futura realização da $1^{\text {a }}$ Conferência Nacional da OAB, e, no boletim de abril de 1958, relatava o estágio de tramitação, na Câmara dos Deputados, do projeto de novo estatuto da Ordem dos Advogados. ${ }^{631}$ Raramente, os boletins traziam artigos opinativos ou de caráter jurídico. Não temos informações sobre a tiragem e a distribuição dos boletins, por isso não podemos afirmar se eram enviados diretamente aos advogados ou se eram remetidos apenas às seções e subseções da $\mathrm{OAB}$.

$\mathrm{Na}$ sua gestão, Nehemias Gueiros propôs-se a modernizar o boletim. Apesar de sua tentativa de refundar o boletim - evidenciada na decisão de numerar como um o primeiro boletim editado na sua gestão - o caráter da publicação permaneceu inalterado. Aliás, o próprio bâtonnier reconheceu que o boletim tinha como função a divulgação das ações da OAB:

"Com este número o Boletim da Ordem inicia a sua edição mensal, destinada à divulgação das atividades da Ordem dos Advogados do Brasil e do seu Conselho Federal."

"Tem por fim, principalmente, estabelecer, pela publicação e pelo intercâmbio de notícias, um conhecimento melhor, entre os advogados de todo o País, da matéria de interesse da classe, debatida no Conselho Federal e nos Conselhos Seccionais, ou onde quer que venha a ser ventilada. "632

A função da $\mathrm{OAB}$ de defesa dos advogados, inscrita nos seus estatutos, mereceu, historicamente, menor ênfase da direção da entidade, e, até meados da década de 1950, significava proteção ao exercício da profissão contra arbitrariedades do governo ou do Judiciário. A partir de então, a função de defesa incorporou a dimensão de proteção social do advogado. Contudo, a cúpula da $\mathrm{OAB}$ não se sentia plenamente confortável nesta tarefa - para o desempenho da qual se confessava com poderes limitados e, talvez,

\footnotetext{
${ }^{631}$ Boletim da Ordem dos Advogados do Brasil, Rio de Janeiro, volume 1, número 2, novembro 1957, p. 1; Boletim da Ordem dos Advogados do Brasil, Rio de Janeiro, volume 2, número 4, abril 1958, p. 1.

${ }^{632}$ Boletim da Ordem dos Advogados do Brasil, Rio de Janeiro, volume 1, número 1, outubro 1957, p. 1.
} 
sem vocação. Os juristas-políticos foram obrigados a se tornar sindicalistas, mas isto parecia constrangê-los. Esta atribuição alargada de defesa da categoria profissional, a $\mathrm{OAB}$ aceitou dividir com outras entidades de advogados, desde que dirigidas pela elite da profissão. ${ }^{633}$ Assim, pela primeira vez na sua história, o Conselho Federal viu-se obrigado a assumir uma demanda que se originava da categoria dos advogados. Há dois fatores fundamentais que explicam tal decisão: o processo de assalariamento da profissão, que colocava em risco o prestígio social dos advogados, e o surgimento de entidades desvinculadas da elite profissional que pretendiam desempenhar funções sindicais em favor da categoria profissional.

As notícias da fundação de entidades concorrentes com a $\mathrm{OAB}$ no âmbito sindical apareceram já no início da década de 1950. Na sessão de 26 de maio de 1953, o Conselho Federal debateu o projeto de lei apresentado pelo deputado federal Antônio Sílvio Cunha Bueno (PSD-SP), que conferia atribuições sindicais à OAB. Washington de Almeida, representante de São Paulo, pronunciou-se em defesa do projeto, patrocinado pela seção paulista da OAB. ${ }^{634}$ Inicialmente, o conselheiro explanou a respeito do fato que motivou a propositura do projeto:

“(...) O estudo (...) proveio da surpresa que [a seção paulista] teve com o reconhecimento, pelo Poder Público, do Sindicato dos Advogados de São Paulo, composto, apenas, de trinta e cinco advogados; e, que, após este reconhecimento,

\footnotetext{
${ }^{633}$ Uma intervenção de Miguel Seabra Fagundes na $1{ }^{\text {a }}$ Conferência Nacional da OAB demonstra tanto o alargamento da concepção de defesa da profissão pela Ordem quanto a disposição da cúpula da $\mathrm{OAB}$ em dividir a proteção social dos advogados com outras entidades, desde que não fossem sindicatos: "Quando se fala em defesa do advogado [como atribuição da $\mathrm{OAB}$ ], trata-se de defesa no exercício da profissão. Defesa, por exemplo, do advogado ao qual o Poder Público crie embaraços na postulação; defesa do advogado ao qual o Tribunal desconsidera. Essas é que são, propriamente, as defesas do advogado. Evidentemente, como as condições sociais, a evolução das coisas fizeram com que as circunstâncias fossem outras hoje e que as instituições de fundo beneficente e de fundo previdenciário surgissem, a expressão 'defesa' comportará um maior âmbito. É, porém, muito bom que alguém se adiante à Ordem e que o faça com maior eficiência, pela facilidade de movimentos, o que a Ordem teria que fazer como ação supletiva e não bem uma ação essencial sua." Anais da $1^{a}$ Conferência Nacional da Ordem dos Advogados do Brasil, op. cit., p. 476.

${ }^{634}$ CF-OAB, Ata de sessão do Conselho Federal, 26/5/1953.
} 
baixou determinações sobre o recolhimento do imposto sindical de toda classe que ascende a, mais ou menos, quatro mil advogados. ", 635

A seguir, esclareceu que o propósito da seção paulista não era submeter os advogados ao sindicalismo corporativista, mas, pelo contrário, garantir uma atuação sindical independente à categoria:

“O seu [o do projeto] propósito não foi o de aliar a Ordem ao sindicalismo restrito de quase obediência ao Poder Público, porém, o de subtrair o advogado militante e, exclusivamente, profissional da entidade sindical comum, tanto que propõe que aquela transformação se concretize numa forma toda especial, com plena independência da futura entidade sindical. ",636

Finalmente, Washington Almeida pediu o apoio do Conselho Federal ao projeto de lei. Na ocasião, o conselheiro Letácio Jansen declarou-se contrário à atribuição de caráter sindical à $\mathrm{OAB}$, porém a ata da sessão silencia em relação aos seus argumentos. ${ }^{637}$ Em outubro de 1954, o Conselho Federal voltou a examinar o projeto de Cunha Bueno, decidindo-se por apoiá-lo. ${ }^{638}$

No dia 30 de julho de 1958, o Correio da Manhã noticiou a organização de uma nova entidade de advogados, a União Nacional dos Advogados (UNA), cujo núcleo fundador era constituído de advogados cariocas, embora a pretensão fosse que a entidade alcançasse âmbito nacional. Um de seus líderes, o advogado Tanus Jorge Bastani, ao explicar ao periódico os propósitos da nova associação, afirmou que, ao assumir um caráter sindical, a UNA propunha-se a suprir uma deficiência da OAB na defesa da categoria profissional. É interessante notar que Bastani atacasse a OAB pela

\footnotetext{
${ }^{635}$ CF-OAB, Ata de sessão do Conselho Federal, 26/5/1953.

${ }^{636}$ CF-OAB, Ata de sessão do Conselho Federal, 26/5/1953.

${ }^{637}$ CF-OAB, Ata de sessão do Conselho Federal, 26/5/1953.

${ }^{638}$ CF-OAB, Ata de sessão do Conselho Federal, 26/10/1954.
} 
ênfase da ação disciplinar sobre a categoria profissional ${ }^{639}$ (crítica que parecia ser razoavelmente disseminada entre os advogados e que será feita também pelo conselheiro federal Letácio Jansen):

"O que nos levou a tomar uma atitude enérgica e decidida, a favor da nossa classe, foi o abandono completo em que se encontram os advogados militantes no Brasil, os quais, embora sob a égide dos Conselhos Regionais da Ordem dos Advogados, jamais obtiveram qualquer amparo, quer em suas vidas profissionais, quer como particulares.”

"Além do abandono em que se encontra o advogado militante, sem proteção de espécie alguma no exercício do seu mandato, frisou o entrevistado, os Conselhos Regionais da Ordem só trabalham, a bem dizer, em inquéritos contra o profissional, pouco se importando com problemas outros que poderiam elevar a classe no conceito público."

“Os juízes - lembra o entrevistado - e demais membros do Judiciário obtiveram tudo o que pediram ao Congresso e ao Legislativo. O humilde operário possui seu Instituto de Aposentadoria e Pensões. As demais classes estão amparadas por leis e instituições, que lhes dão assistência médica, dentária, hospitalar, econômica e montepios. Os advogados têm apenas Deus, no Céu, e a Ordem dos Advogados, na Terra. Deus para nos proteger contra os inquéritos da Ordem ... "640

Bastani explicitou que os objetivos da nova associação eram a proteção social e do mercado de trabalho do advogado:

"Ao encetarmos a fundação da União Nacional dos Advogados, com a sigla UNA, foi com o fito de cooperar com os poderes constituídos e exigir desses

\footnotetext{
${ }^{639}$ No discurso proferido na $2^{\mathrm{a}}$ Conferência Nacional da OAB, Rui de Azevedo Sodré responderá a este gênero de crítica: "A despeito de ainda haver colegas que julgam apressadamente e sem conhecimento de causa, [a OAB] como um órgão encarregado de apenas punir e de cobrar anuidades, a verdade, felizmente, é bem diversa e a ocasião é azada para um esclarecimento público." Anais da $2^{a}$ Conferência Nacional da Ordem dos Advogados do Brasil, op. cit., p. 10.

${ }^{640}$ Correio da Manhã, 30/7/1958, $1^{\circ}$ caderno, p. 3.
} 
mesmos poderes imunidades profissionais ao advogado militante, aposentadoria, benefício de casa própria, hospitais e amparo médico-dentário e, ainda, férias coletivas, tribunais de alçada, nomeações de advogados militantes de comprovada idoneidade para cargos e funções públicas onde devem prevalecer os bacharéis em Direito e não militares ou protegidos políticos, maior respeito e acatamento por parte dos Poderes Públicos ao profissional no exercício do mandato, ampla publicidade para os concursos e provimentos de assistentes ou consultores jurídicos, juízes e promotores públicos, seleção, na classe, com expulsão dos maus, uso obrigatório da inscrição profissional em todo o País sem a exigência de inscrição em seções regionais. "641

Cerca de uma semana depois, o mesmo Correio da Manhã relatou a realização da assembleia de fundação da UNA, presidida por Tanus Bastani. Segundo o periódico, a sessão contara com a presença de centenas de advogados, provenientes, sobretudo, de São Paulo, Rio de Janeiro, Minas Gerais e Espírito Santo. ${ }^{642}$

Durante a $1^{\text {a }}$ Conferência Nacional da OAB uma das sessões dedicou-se a debater a relação da Ordem com outras entidades de advogados bem como a sindicalização da categoria profissional. Nesta ocasião, Noé Azevedo, deu o seu testemunho sobre a colaboração mantida pela seção paulista da Ordem, por ele presidida, com a Associação dos Advogados de São Paulo (AASP) e o Instituto dos Advogados de São Paulo. Todavia, fez questão de enfatizar que, nestas iniciativas, a OAB paulista reservava-se a precedência sobre as outras entidades na interlocução com o Estado acrescentando que esta "união da classe tem concorrido para que sejamos recebidos com a necessária deferência e alta compreensão" pela cúpula dos três poderes de São Paulo. ${ }^{643}$ Não houve discordâncias, na conferência, sobre a legitimidade da existência de outras entidades de advogados e mesmo a conveniência de se cultivar um vínculo de colaboração entre elas e a $\mathrm{OAB}$, desde que sob liderança da última. Note-

${ }^{641}$ Correio da Manhã, 30/7/1958, $1^{\circ}$ caderno, p. 3.

${ }^{642}$ Correio da Manhã, 5/8/1958, $1^{\circ}$ caderno, p. 13.

${ }^{643}$ Anais da $1^{a}$ Conferência Nacional da Ordem dos Advogados do Brasil, op. cit., p. 478-479. 
se que a disposição da Ordem era de colaborar, no campo da defesa da profissão (principalmente na proteção social ao advogado), com entidades que também eram dirigidas pela elite profissional. Muito diferente era sua disposição em relação aos sindicatos de advogados, comandados por setores "plebeus" da categoria profissional.

Dentre as resoluções do encontro estavam:

"Tendo como pressuposto indiscutível a coexistência da Ordem e das associações de classe, cumpre estimular suas relações recíprocas, melhorando-as e desdobrando-as."

“(...) Na defesa da classe, cabe preeminência à Ordem. ",644

$\mathrm{Na}$ mesma sessão da $1^{\text {a }}$ Conferência Nacional, foram unânimes os pronunciamentos sobre a inconveniência da existência de sindicatos de advogados. Observa-se que a elite dos advogados temia o surgimento de sindicatos, que poderiam se vincular ao Estado e serem dirigidos por advogados esquerdistas. Outrossim, receava pela redução de seu papel como representante dos interesses da categoria profissional o que poderia fazer decrescer, por conseguinte, sua força entre os advogados e seu prestígio junto ao Estado. No debate, os participantes da conferência endossaram a estratégia que o Conselho Federal adotara para desestimular a organização dos sindicatos de advogados: a OAB deveria incorporar, entre as suas atribuições legais, a ação sindical. E, mais importante, deveria dispensar o advogado que pagasse anuidade à Ordem do pagamento do imposto sindical. Como a anuidade era obrigatória, na prática, todo advogado ficaria dispensado de pagar o imposto sindical. Nehemias Gueiros revelou o estratagema, empregado na elaboração do projeto de novo estatuto da entidade:

“Os sindicatos só proliferam, só florescem à custa da obrigatoriedade do Imposto Sindical (...) incluímos no anteprojeto um dispositivo que, ao meu ver,

${ }^{644}$ Ibidem, p. 544. 
resolve o problema sem atingir a Constituição e essa vocação universal sindicalista (...) Tal dispositivo declara que o advogado que paga anuidade à Ordem dos Advogados está isento do pagamento do Imposto Sindical. "645

Os participantes da conferência confessaram o temor de que os sindicatos de advogados se subordinassem ao Estado. Temístocles Marcondes Ferreira afirmou: "Tenho receio de que os órgãos sindicais (...) queiram entrar em atividade. Refiro-me aos órgãos do Ministério do Trabalho. "646 Porém, Nehemias Gueiros asseverou que, com a aprovação do projeto de novo estatuto da $\mathrm{OAB}$, e a consequente atribuição de função sindical à Ordem, o perigo seria afastado: “Com esse fato, [a $\mathrm{OAB}$ ] também se torna sindicato - órgão de atividade sindical - sem as explorações demagógicas e eleitoreiras da atividade sindical no Brasil. "647

Aparentemente, a estratégia da elite profissional de desestimular a criação de sindicatos de advogados foi bem sucedida. ${ }^{648}$ Segundo o IBGE, em 1967, existiam, no

\footnotetext{
${ }^{645}$ Ibidem, p. 487. Este dispositivo foi preservado no Estatuto de 1963, que, no seu artigo 143, estabelecia: "O pagamento de contribuição anual à Ordem exclui os inscritos nos seus quadros de incidência obrigatória do imposto sindical."

${ }^{646}$ Anais da $1^{a}$ Conferência Nacional da Ordem dos Advogados do Brasil, op. cit., p. 488.

${ }^{647}$ Ibidem, p. 488.

${ }^{648} \mathrm{Na}$ sessão realizada pelo Conselho Federal para comemorar o início da vigência do novo estatuto, o conselheiro Nehemias Gueiros destacou alguns aspectos da nova lei. Em relação ao caráter da OAB e a sua dimensão sindical, afirmou: "Qualificou-se definitivamente a sua categoria jurídica, como figura indubitavelmente sui generis, de corporação aberta (...), destinada à seleção, disciplina e defesa da classe dos advogados, mas de natureza também sindical, com o pressuposto indispensável de representar (...) os interesses gerais da classe dos advogados e os individuais, relacionados com o exercício da profissão (...) Reconhecendo a vocação universal à sindicalização de todas as classes profissionais, que hoje constitui prerrogativa integrada na Declaração Universal dos Direitos do Homem (...) a nova lei deixou em branco o problema da existência e da coexistência da Ordem com os Sindicatos profissionais de advogados, mas, precisamente porque esta, com as atribuições agora acrescentadas, atende aos interesses profissionais de que podem cuidar os sindicatos, estabeleceu que o pagamento da anuidade exclui os inscritos nos seus quadros da incidência obrigatória do imposto sindical (art. 143). Podem os sindicatos, a partir de hoje, continuar a apresentar-se com o poder de representação individual dos advogados seus associados, na ausência, mas nunca em concorrência com igual representação exibida pela Ordem, mas não podem, evidentemente, representar os interesses gerais da classe, que estes já eram e agora continuam a ser, por disposição expressa da lei, privativos da própria Ordem." CF-OAB, Ata de sessão do Conselho Federal, 11/6/1963.
} 
Brasil, 2.582 advogados sindicalizados, todos na Guanabara. ${ }^{649}$ Neste período, o número de advogados do país devia girar em torno dos 35 mil (Tabela 2).

Quando os advogados estavam enquadrados na Lei Orgânica da Previdência Social de 1960, o Sindicato dos Advogados da Guanabara assinou um termo de acordo com a delegacia do Instituto de Aposentadoria e Pensões dos Comerciários (IAPC) do estado para regular a contribuição previdenciária obrigatória dos advogados cariocas. $\mathrm{O}$ Conselho Federal da OAB insurgiu-se contra este acordo, que era uma evidente afronta à pretensão do organismo de representar com exclusividade os interesses da categoria profissional. Nehemias Gueiros, em parecer preparado sobre o assunto para o Conselho Federal, pedia uma resposta vigorosa ao que lhe parecia usurpação de uma atribuição da Ordem dos Advogados:

"E que a Ordem dos Advogados do Brasil, pelo seu órgão supremo - com a ampla e inequívoca representação sindical da classe, outorgada por lei (...) faça valer, até através do Poder Judiciário, se necessário for, a sua autoridade e a sua competência exclusiva de falar, em âmbito nacional, por todos os profissionais obrigatoriamente inscritos nos seus quadros (advogados, provisionados, solicitadores e estagiários), para que se fixe, no Ministério do Trabalho, o salário-base que constituirá o parâmetro das tabelas de contribuições (...) sem as quais não se pode iniciar o pagamento das contribuições (...), 650

\section{3.) As Conferências Nacionais da OAB}

Resta, agora, examinar o significado das Conferências Nacionais da OAB quanto às relações da entidade com a categoria profissional. Antes de mais nada, elas representaram uma tentativa de coesionar as elites de advogados de todo o país em torno

\footnotetext{
${ }^{649}$ Anuário estatístico do Brasil 1969. Rio de Janeiro: IBGE, 1969, v. 30. Disponível em: $<$ www.ibge.gov.br>. Acesso em 29/10/2010.

${ }^{650}$ GUEIROS, Nehemias, op. cit., p. 223.
} 
das prioridades da cúpula da OAB. ${ }^{651}$ As conferências também serviram para aproximar o Conselho Federal das seções estaduais. Ademais, davam visibilidade e legitimidade às demandas da elite profissional, ao reunir, por alguns dias, algumas centenas de advogados de todo o país, convidar autoridades para o evento e divulgar, com cobertura diária dos grandes jornais, suas prioridades e reivindicações.

O exame de alguns pronunciamentos e, sobretudo, do seu regimento provam que as conferências eram concebidas como um canal de interlocução entre o Conselho Federal e as seções estaduais, com a participação de outras entidades da elite profissional e de juristas notáveis. Não eram (a não ser como um efeito colateral, mas controlado pelos mecanismos de participação e votação) instâncias de participação direta dos advogados. Assim, ao justificar a sua proposta de realização das conferências nacionais, o presidente da OAB Nehemias Gueiros listou:

“Considerando ser o pensamento desta Presidência promover a máxima cooperação e entendimento entre os poderes central e seccional da organização $(\ldots)$,

"Considerando que numerosos assuntos merecem ser apreciados $e$ discutidos fraternalmente entre os órgãos através dos quais a Ordem dos Advogados do Brasil exerce as suas atribuições;

“(...) Considerando, ante o exposto, ser de grande proveito a realização de reuniões periódicas, sob forma de convenções, reunindo os membros do Conselho Federal e das Seções e Subseções, para o debate de temas do interesse da classe e atinentes à ordem jurídica". 652

\footnotetext{
${ }^{651}$ José Miramar da Ponte, delegado cearense à $2^{\mathrm{a}}$ Conferência Nacional da OAB, ao discursar no encerramento do encontro, vislumbrava a possibilidade que dele emergisse uma agenda consensual da elite profissional: "Reconhecendo a relevância dos trabalhos e das conclusões aprovadas por esta Segunda Conferência (...) manifestamos as nossas esperanças em que dela surja o roteiro necessário e fundamental para atividades profícuas de nossa classe, nos próximos anos, conquistando-nos o futuro e guindando os advogados brasileiros ao seu alto e digno destino: a classe dos Advogados, respeitada e consagrada como seminário de dignidades, à semelhança da posição que desfrutava na antiga Roma." Anais da $2^{a}$ Conferência Nacional da Ordem dos Advogados do Brasil, op. cit., p. 318-319.

${ }^{652}$ Boletim da Ordem dos Advogados do Brasil, Rio de Janeiro, volume 2, número 4, abril 1958, p. 2.
} 
Entre suas justificativas, Gueiros não mencionou a intenção de estabelecer, por intermédio das conferências, uma interlocução direta com a categoria profissional. No discurso proferido na abertura da $1^{\text {a }}$ Conferência Nacional da OAB, Gueiros sublinhou a motivação de constituir as conferências como um instrumento de aproximação entre o Conselho Federal e as seções estaduais. Ele reconheceu a deficiência da representatividade das delegações estaduais no Conselho Federal, formadas por advogados que, embora vinculados às seções estaduais da $\mathrm{OAB}$ e originários dos estados que representavam, estavam, há muito, radicados na capital da República e, portanto, afastados das demandas específicas dos seus pares nos estados. O bâtonnier também admitiu que esta distorção representativa prejudicava o caráter federativo da Ordem dos Advogados. Embora tenha explanado o problema com prudência, Gueiros tinha razão. Na prática, a elite dos advogados carioca, instalada no Conselho Federal, dirigia o conjunto da categoria profissional do país. ${ }^{653}$

O regimento da $1^{\text {a }}$ Conferência foi aprovado pelo Conselho Federal em junho de 1958. Ele foi modificado para a $2^{\mathrm{a}}$ Conferência, mas as alterações foram bem poucas e secundárias. $^{654} \mathrm{O}$ artigo segundo do regimento distinguia três categorias de participantes: a.) os membros natos, que eram os dirigentes das seções e subseções da $\mathrm{OAB}$ e os conselheiros federais da Ordem; b.) os membros convidados, que eram dirigentes de outras entidades de advogados e também juristas e advogados ilustres convidados pela organização da conferência; c.) os membros efetivos, que eram todos os advogados inscritos na OAB. O artigo quarto estabelecia que cabia ao Conselho

\footnotetext{
${ }^{653}$ Anais da $1^{a}$ Conferência Nacional da Ordem dos Advogados do Brasil, op. cit., p. 7-8. Em depoimento publicado, em 1980, pelo jornal da seção pernambucana da Ordem, Paulo Américo Maia, então presidente do Conselho Seccional da OAB da Paraíba, reconhecia a grande distância que havia, até o início da década de 1960, entre as seções estaduais e o Conselho Federal da OAB: “(...) [Até 1963], a Ordem dos Advogados ficou confinada praticamente no Rio de Janeiro. O Conselho Federal era então composto dos representantes dos Estados, com pouca ou quase nenhuma convivência com os advogados de quem receberam o mandato e as eleições para os dirigentes daquele colegiado, para as funções dirigentes máximas da classe não tinha a participação das bases, isto é, das seções dos Estados, o que representava um distanciamento contrário aos interesses da profissão nas seções estaduais que se manifestaram pelos grandes problemas da profissão e sua solução, dependendo das resoluções do Conselho Federal, impunha uma modificação da situação." VIANNA, Luiz Werneck; VIANNA, Maria Lucia Teixeira Werneck, op. cit., p. 112.

${ }^{654} \mathrm{O}$ regimento da $1^{\mathrm{a}}$ Conferência e as alterações que lhe foram feitas para a $2^{\mathrm{a}}$ Conferência encontramse, respectivamente, em: CF-OAB, Atas de sessão do Conselho Federal, 17/6/1958 e 7/6/1960.
} 
Federal, por meio da comissão executiva da conferência, a organização e a direção da mesma. O presidente desta comissão executiva era o presidente da $\mathrm{OAB}$ e o seu secretário era o secretário-geral do Conselho Federal. O artigo quinto estabelecia que o temário e os relatores das teses seriam escolhidos no âmbito da comissão executiva. Como esta era nomeada pelo Conselho Federal, fica claro que, na prática, era este órgão que escolhia os temas a serem debatidos nas conferências, assim como os advogados que os abordariam nas teses apresentadas, além de organizar e dirigir o evento.

A conferência desdobrava-se em sessões das comissões especiais e nas reuniões plenárias. Dentre estas últimas, duas tinham caráter solene, sendo uma de instalação e outra de encerramento. Previa-se, ainda, uma terceira reunião plenária, destinada a deliberar sobre as indicações das comissões especiais. ${ }^{655}$ As sessões das comissões especiais iniciavam-se com a leitura da tese pelo seu relator. Em seguida, abria-se o debate e, depois, votavam-se as indicações. Nas comissões especiais, todos os participantes, fossem eles membros natos, convidados ou efetivos, tinham direito de voz e voto. ${ }^{656}$ Porém, na reunião plenária que sancionaria ou reprovaria as indicações das comissões, a participação era restrita às cúpulas estaduais da OAB. Nela apenas as delegações estaduais tinham direito a voto. Cada delegação estadual tinha direito a um voto, exercido pelo seu presidente - que, geralmente, era o presidente da seção estadual da Ordem. $\mathrm{O}$ artigo $18^{\circ}$ do regimento estabelecia que as decisões da conferência teriam o caráter de "simples recomendações".

A $1^{\text {a }}$ Conferência Nacional da OAB foi realizada no Rio de Janeiro entre os dias 4 e 11 de agosto de 1958. A $2^{\text {a }}$ Conferência, ocorrida em São Paulo, aconteceu entre os dias 5 e 11 de agosto de 1960. A imprensa carioca cobriu diariamente ambos os encontros, reproduzindo pronunciamentos lá feitos e relatando os debates travados e as conclusões adotadas. ${ }^{657}$ Segundo o Correio da Manhã, seiscentos advogados

\footnotetext{
${ }^{655}$ Artigos $7^{\circ}$ e $8^{\circ}$ do regimento. CF-OAB, Ata de sessão do Conselho Federal, 17/6/1958.

${ }^{656}$ Artigo 12 do regimento. CF-OAB, Ata de sessão do Conselho Federal, 17/6/1958.

${ }^{657}$ Diário de Notícias, 5/8/1958, $1^{\text {a }}$ seção, p. $2 ; 7 / 8 / 1958,1^{\text {a }}$ seção, p. $2 ; 8 / 8 / 1958,1^{a}$ seção, p. 3 e 6; 10/8/1958, $1^{\mathrm{a}}$ seção, p. 6; Correio da Manhã, 5/8/1958, $1^{\circ}$ caderno, p. 13; 8/8/1958, $1^{\circ}$ caderno, p. 11; 9/8/1958, $1^{\circ}$ caderno, p. $7 ; O$ Jornal, $7 / 8 / 1958$, p. $1^{\text {a }}$ seção, p. $7 ; 8 / 8 / 1958,1^{\text {a }}$ seção, p. $7 ; 9 / 8 / 1958,1^{\text {a }}$ seção, p. 5; 12/8/1958, $1^{\text {a }}$ seção, p. 12; Correio da Manhã, 4/8/1960, $1^{\circ}$ caderno, p. 3; 9/8/1960, $1^{\circ}$
} 
participaram da $1^{\mathrm{a}}$ Conferência e trezentos da $2^{\mathrm{a}}$ Conferência. ${ }^{658} \mathrm{~A}$ julgar pelo número de participantes, deve-se supor que eles extrapolassem os círculos da elite profissional. No entanto, não há dúvidas de que as duas conferências foram inteiramente controladas pelos advogados de elite, como evidenciava o seu regimento.

O temário das duas primeiras conferências nacionais da $\mathrm{OAB}$ girou em torno de questões de interesse corporativo (como o ensino jurídico e a questão previdenciária), das dimensões da atuação profissional do advogado (como a advocacia extrajudicial) e de aspectos do funcionamento do Judiciário. ${ }^{659}$ Os relatores destes encontros, responsáveis pela elaboração das teses que serviam de base para o debate, eram sempre bacharéis ilustres: conselheiros federais da $\mathrm{OAB}$, membros das seções estaduais da Ordem ou de outras entidades de advogados (como os Institutos de Advogados ou a AASP) ou juristas e professores notórios. ${ }^{660}$

caderno, p. 2 e $8 ; 10 / 8 / 1960,1^{\circ}$ caderno, p. 2 e $8 ; 11 / 8 / 1960,1^{\circ}$ caderno, p. 3 e $10 ; 12 / 8 / 1960,1^{\circ}$ caderno, p. 16.

${ }_{658}$ Correio da Manhãa, 8/8/1958, $1^{\circ}$ caderno, p. 11; Correio da Manhã, 11/8/1960, p. 3 e 10.

${ }^{659} \mathrm{Na}$ sessão de encerramento da $1^{\text {a }}$ Conferência, Nehemias Gueiros resumiu assim o temário: "O longo temário debatido, verdadeiro corte cirúrgico na intimidade dos problemas da profissão, postos no seu contato com os diversos Poderes Públicos, com os Institutos de ensino jurídico, com a ética profissional e a jurisdição disciplinar, com o exercício e a defesa das próprias atividades, com a experiência do sistema processual vigente, com a necessidade do seguro social e da justa retribuição do trabalho, trouxe à discussão teses que constituem, no seu conjunto, uma monografia valiosa para o estudo da conjuntura da advocacia no Brasil (...)"Anais da $1^{a}$ Conferência Nacional da Ordem dos Advogados do Brasil, op. cit., p. 547.

${ }^{660} \mathrm{O}$ temário e os relatores das duas conferências estão em: Anais da $1^{a}$ Conferência Nacional da Ordem dos Advogados do Brasil, op. cit., p. 768; Anais da $2^{a}$ Conferência Nacional da Ordem dos Advogados do Brasil, op. cit., p. 359-360. 


\section{CONCLUSÃO}

Os bacharéis que comandaram a $\mathrm{OAB}$ no período estudado eram descendentes diretos dos juristas-políticos que atuaram decisivamente na fundação e consolidação do Estado nacional. Devotos de um liberalismo que justificava a escravidão pelo direito à propriedade e recusava o alargamento da cidadania política sob o argumento de que a condução do Estado cabia, com exclusividade, a homens "esclarecidos", os juristaspolíticos encamparam os interesses sociais dominantes. Muitos deles conciliavam suas funções públicas com a advocacia. Esta elite dos advogados do Império criou a sua associação profissional, o Instituto dos Advogados Brasileiros (IAB). Distinguem-se nítidas linhas de continuidade entre o $\mathrm{IAB}$ e a $\mathrm{OAB}$, sobretudo no que diz respeito às atribuições das duas entidades. O Instituto pretendia contribuir para o aperfeiçoamento das leis e da administração da justiça, bem como moralizar a advocacia, com base no seu sistema de valores profissionais.

No período republicano, os juristas-políticos enfrentaram a oposição de elites profissionais emergentes: militares, engenheiros e, mais tarde, economistas e administradores. Os bacharéis resistiram e mantiveram-se como elementos centrais no interior da elite política. Porém, ao longo do século XX, desenvolveu-se um lento, porém implacável, declínio da participação dos juristas-políticos na direção do Estado.

Advirta-se que os juristas-políticos compunham apenas uma pequena parcela da categoria profissional dedicada à advocacia - o seu segmento mais prestigiado e bem remunerado. A estratificação da categoria profissional apoiou-se em elementos mais ou menos decisivos de acordo com o período histórico. Entre os quais pode-se citar a posse de um diploma de bacharel em direito, a atuação em tribunais de primeira instância ou superiores, o perfil da clientela (abastada ou modesta), as condições de trabalho (profissional liberal ou assalariado) e o acúmulo de cargos nobilitantes, como o de parlamentar ou professor universitário.

Com intensidade variável, a inflação de diplomas assombrou os bacharéis desde o Império. A concorrência profissional acentuou-se com o fim do exclusivismo estatal 
no ensino superior, ainda no final do século XIX. A elite dos advogados procurou estabelecer o controle sobre a oferta de serviços, restringindo a ação dos rábulas, e logrou conquistar, ainda na Primeira República, a aprovação de algumas leis estaduais que regulamentaram o exercício da advocacia. Sua vitória mais duradoura, contudo, foi a criação da $\mathrm{OAB}$, que lhe propiciou instrumentos mais eficazes para atuar sobre o mercado de trabalho.

Foram os juristas-políticos que comandavam o IAB os encarregados de organizar a nova entidade. No entanto, mesmo contando com o apoio do governo revolucionário, enfrentaram resistências importantes na execução de sua tarefa, tanto entre a elite quanto entre a base da categoria profissional.

Gozando de autonomia formal em relação ao Estado, a OAB manteve-se muito próxima do governo, com o qual contava para sua consolidação institucional. A proximidade com o Estado fortaleceu a Ordem frente à categoria profissional, mas desanimou eventuais protestos contra os atentados governamentais à tradição jurídica liberal.

Todavia, o panorama transformou-se em 1944, quando, na direção da OAB, o componente político sobrepôs-se aos interesses corporativos. Este movimento foi acompanhado pela ascensão do grupo de liberais oposicionistas à presidência do Conselho Federal da entidade. Afastados da direção do Estado desde o Governo Provisório ou o advento do Estado Novo, os integrantes da oposição liberal, aproveitando-se do enfraquecimento do regime, ocuparam todas as instâncias possíveis da sociedade civil para dar combate a Vargas. Assim, o Conselho Federal da OAB incorporou-se, como um ator destacado, à frente oposicionista formada por associações civis e jornais e cuja expressão partidária era a UDN.

Aspirando retornar ao comando do Estado e restabelecer a institucionalidade liberal, os conselheiros federais atemorizaram-se com a mobilização popular que marcou o fim do Estado Novo, temerosos de que a transição política fugisse ao controle das classes dominantes. Para garantir uma derrota do regime que não abalasse as estruturas sócio-econômicas do país, o Conselho Federal recorreu ao Exército e ao Judiciário. 
A modernização do capitalismo brasileiro iniciada na década de 1950 incidiu diretamente sobre a advocacia. O paradigma liberal que moldava tradicionalmente a profissão passou a conviver com a figura do advogado-empregado. O Conselho Federal da $\mathrm{OAB}$ enfrentou as transformações sofridas pela categoria profissional com pragmatismo, procurando adequá-la aos novos tempos. Assim, reconheceu a advocacia preventiva, conformou-se com o assalariamento dos advogados e procurou garantir proteção social à categoria profissional. Desta forma, a agenda corporativa revelou-se urgente para a (tentativa de) preservação do status social dos advogados e a legitimidade da OAB perante a categoria profissional. Apesar do udenismo dominante no Conselho Federal, a preeminência da pauta corporativa obrigava o organismo a interpelar, incessantemente, o Estado. Dentre as iniciativas destes anos, o Conselho Federal obteve inegáveis êxitos na aprovação do novo estatuto e da previdência social para os advogados. Contudo, descobriu-se impotente para fazer face ao crescimento exponencial de advogados e, especialmente, de bacharéis em Direito. Este fracasso alimentou o fantasma da proletarização da categoria profissional que rondava a elite dos advogados.

No início da década de 1960, o Conselho Federal voltou a atuar diretamente na arena política. Sua postura em defesa da ordem jurídica não era neutra em relação às lutas que dividiam o país. A manutenção estrita da ordem jurídica impedia a expansão da cidadania política e social. O organismo, desde meados de 1962, aderiu à campanha que, denunciando a infiltração comunista no Brasil, preparou a deposição de Goulart. O apoio inequívoco do Conselho Federal ao golpe de Estado traiu o legalismo do órgão e revelou que, na sua hierarquia de valores, a defesa do status quo sobrepunha-se à defesa da ordem jurídica.

Ao considerar o conjunto dos conselheiros federais, pode-se dizer que, de uma certa maneira, eles constituíam um grupo homogêneo. Compunham a elite da profissão e vinculavam-se às classes dominantes. Nascidos ou, mais comumente, radicados no 
Rio de Janeiro, provavelmente frequentavam as mesmas livrarias e cafés. Possuíam veleidades artísticas e intelectuais semelhantes, uns inclinando-se para a poesia ou a crítica literária, outros para a história ou a geografia. Pertenciam a associações literárias, científicas e jurídicas. A política para eles era uma paixão e um dever de elite, vivida por meio do periodismo, pelo exercício de cargos públicos e pela vida partidária.

Contudo, certos elementos distinguiam estes bacharéis entre si. Ao contrário do que ocorrera com os juristas-políticos do Império, os conselheiros federais tinham origens acadêmicas relativamente diversas, ainda que uma parte significativa deles tenha se formado em instituições cariocas. Outro elemento a ser considerado são os laços que mantinham com as diferentes elites de advogados dos estados, pois eram elas que, instaladas nos conselhos seccionais da Ordem, indicavam os seus representantes no Conselho Federal. Finalmente, se o gosto pela política os unia, suas posições partidárias os separavam. Havia dois grupos partidários no interior do Conselho Federal: um udenista e outro pessedista. O grupo udenista contava com mais bacharéis oriundos de famílias com tradição nos altos postos das carreiras jurídicas e na direção do Estado. O grupo pessedista era marcado pela elevada participação de seus integrantes no Estado Novo e pelo desempenho de mandatos no Congresso Nacional e no Executivo Federal durante o período democrático. Contudo, os udenistas continuavam a ser hegemônicos nas entidades que congregavam os advogados no país. Assim, eles não apenas eram dominantes no Conselho Federal da $\mathrm{OAB}$, mas também na direção das seções estaduais da Ordem e no IAB.

A dimensão corporativa da ação da $\mathrm{OAB}$ animou os pleitos da elite dos advogados para a sua criação. Ao longo de sua história, as funções de seleção e disciplina foram mantidas como centrais na atuação da Ordem dos Advogados, e mesmo aperfeiçoadas. Na década de 1950, graças ao progressivo assalariamento dos advogados e à intensificação da concorrência profissional, o terceiro eixo tradicional de ação corporativa - a defesa da categoria profissional - ganhou contornos sindicais. No entanto, a Ordem dos Advogados reclamava para si uma atribuição que transcendia os limites do exercício profissional. A reivindicação do papel de defensora da ordem jurídica - surgida no embate com o Estado Novo - firmou-se à medida em que a OAB 
procurou se autonomizar do Estado. Com o estatuto aprovado em 1963, este papel ganhou reconhecimento legal.

O Conselho Federal usufruía de uma interlocução direta com o Estado. Os dirigentes da $\mathrm{OAB}$ contavam com acesso privilegiado às principais autoridades da República, nos três poderes. A partir da luta contra o Estado Novo, a Ordem dos Advogados reforçou a autonomia em relação ao Estado como um dos pilares de sua identidade institucional. E, ao longo do período democrático, a entidade consolidou sua relativa independência. Neste sentido, a vitória judicial contra o TCU, dispensando-lhe de prestar contas ao tribunal, constituiu-se um marco decisivo. Contudo, a defesa dos interesses da corporação impelia o Conselho Federal a recorrer incessantemente ao Legislativo e, especialmente, ao governo. Em geral, o Estado demonstrava-se receptivo às demandas da OAB. No início da década de 1960, entretanto, o Conselho Federal experimentou uma crise aberta na sua relação com o governo Goulart, derivada não apenas da franca oposição do órgão à política de reformas do presidente da República, mas também da percepção de que o governo desrespeitava o padrão de acesso privilegiado da $\mathrm{OAB}$ ao Estado.

De todo modo, havia, nas complexas relações que a Ordem dos Advogados mantinha com o Estado, elementos estruturais de tensão. No que dizia respeito ao Congresso Nacional, tratava-se da legislação sobre o exercício da advocacia e das atribuições da $\mathrm{OAB}$. Com relação ao governo, eram as arbitrariedades policiais contra advogados e o papel de contrapoder que a OAB se auto-atribuía.

O Conselho Federal da OAB estava longe de funcionar como uma instância de representação dos interesses imediatos dos advogados. Era antes um centro disciplinador e iluminista a pairar sobre a categoria profissional. Ainda assim, as iniciativas do órgão nos seus momentos de maior politização contaram com inegável adesão dos advogados e das entidades que os congregavam. O liberalismo conservador que informava a ação do Conselho Federal continuava a predominar na categoria profissional, malgrado a sua diversidade ideológica. No entanto, a partir da década de 1950, o Conselho Federal tornou-se mais permeável às demandas da categoria profissional. Neste momento, surgiam novas entidades portadoras de uma agenda 
sindical voltada aos advogados, percebidas como uma ameaça à representação da categoria profissional desempenhada pela OAB. Em resposta, o órgão assumiu a função sindical e teceu alianças com outras entidades de advogados de elite.

Quanto às conferências nacionais da Ordem, não se deve pensar que tenham sido criadas com o intuito de estabelecer um canal de expressão do conjunto da categoria profissional. Elas visavam o alargamento da base de apoio do Conselho Federal entre os advogados de elite, num momento em que o órgão via-se desafiado por várias questões corporativas de relevo.

Como demonstra Denise Rollemberg, o Conselho Federal apoiou a ditadura militar até inícios da década de $1970 .{ }^{661}$ Neste período, tornou-se cada vez mais evidente a incompatibilidade entre o projeto de modernização capitalista implementado pelo Estado pós-1964, especialmente após o Ato Institucional no 5 , e a tradição jurídica brasileira de que a $\mathrm{OAB}$ se considerava guardiã. ${ }^{662}$ Ademais, o autoritarismo que sustentava a modernização do capitalismo no Brasil passou a comprometer a integridade física dos advogados e sua militância profissional. ${ }^{663}$ Ainda que a repressão política lhes tenha atingido diretamente apenas numa pequena parcela, os advogados sentiram a categoria ameaçada como um todo. Essa sensação serviu para coerir os advogados em torno da defesa de suas prerrogativas profissionais. Outra importante fator de coesão foi a resistência à tentativa do regime em abolir o status especial da $\mathrm{OAB}$, subordinando-a ao Ministério do Trabalho. ${ }^{664}$

Como o Estado autoritário preservara, ainda que rigidamente controladas, instituições da democracia liberal, como o parlamento, os partidos políticos e as

\footnotetext{
${ }^{661}$ ROLLEMBERG, Denise, op. cit.

${ }^{662}$ VIANNA, Luiz Werneck. Os intelectuais da tradição e a modernidade: os juristas-políticos da OAB, op. cit., p. 120-121.

${ }^{663}$ PEREIRA, Caio Mário da Silva. Ordem dos Advogados do Brasil (OAB). In: ABREU, Alzira Alves de et alli (coord.), op. cit.; SKIDMORE, Thomas. Brasil: de Castelo a Tancredo. Rio de Janeiro: Paz e Terra, 1988, p. 329.

${ }^{664}$ BONELLI, Maria da Glória, op. cit, p. 67-68.
} 
eleições, os juristas-políticos aproveitaram-se destes canais, revigorados a partir de 1974, para combater o regime. Nesta luta, juntaram-se a aliados improváveis há dez anos: os trabalhadores, sobretudo os metalúrgicos do ABC paulista. Até 1964, a OAB arrimou-se numa posição formalista de defesa da ordem jurídica - que teve um efeito conservador no cenário político do país. Mais tarde, nas trincheiras do combate que travou contra a ditadura, a entidade avançou em suas posições políticas. Num contexto em que os juristas-políticos eram aliados de um sindicalismo que unia a luta por reivindicações específicas à luta pela redemocratização, a entidade conciliou o formal com o substantivo na defesa da democracia. ${ }^{665}$

${ }^{665}$ VIANNA, Luiz Werneck. Os intelectuais da tradição e a modernidade: os juristas-políticos da OAB, op. cit., p. 129-130. 
FONTES DOCUMENTAIS E BIBLIOGRAFIA

\section{1.) Arquivos e bibliotecas consultadas}

Arquivo do Conselho Federal da OAB (Brasília)

Biblioteca do Conselho Federal da OAB (Brasília)

Biblioteca Nacional (Rio de Janeiro)

Biblioteca do IUPERJ (Rio de Janeiro)

Biblioteca do IAB (Rio de Janeiro)

Arquivo do Conselho Seccional da OAB do Rio de Janeiro

Biblioteca do Conselho Seccional da OAB de São Paulo

Biblioteca Florestan Fernandes, FFLCH-USP (São Paulo)

Biblioteca do IEB-USP (São Paulo)

Biblioteca da FEA-USP (São Paulo)

\section{2.) Fontes documentais}

a.) Atas do Conselho Federal da OAB, 1945-1964 ${ }^{666}$

b.) Boletins do Conselho Federal da OAB

Boletim do Conselho Federal da Ordem dos Advogados do Brasil, Rio de Janeiro, 1954.

Boletim da Ordem dos Advogados do Brasil, Rio de Janeiro, volume 1, número 1, outubro 1957.

Boletim da Ordem dos Advogados do Brasil, Rio de Janeiro, volume 1, número 2, novembro 1957.

Boletim da Ordem dos Advogados do Brasil, Rio de Janeiro, volume 1, número 3, dezembro 1957.

\footnotetext{
${ }^{666}$ As atas de 1949 foram extraviadas do Arquivo do Conselho Federal da OAB. Entretanto, elas foram publicadas pelo Jornal do Comércio, o que me permitiu consultá-las.
} 
Boletim da Ordem dos Advogados do Brasil, Rio de Janeiro, volume 2, número 4, abril 1958.

Boletim da Ordem dos Advogados do Brasil, Rio de Janeiro, ano 28, número 28, 1962.

c.) Anais das Conferências Nacionais da OAB

Anais da $1^{a}$ Conferência Nacional da Ordem dos Advogados do Brasil. Rio de Janeiro: Folha Carioca Editora, 1987.

Anais da $2^{a}$ Conferência Nacional da Ordem dos Advogados do Brasil. São Paulo: Revista dos Tribunais, 1961.

d.) Jornais

A Noite

Edições de 17/10/1945, 22/10/1945 e 23/10/1945.

\section{Correio da Manhã}

Edições de 26/06/1945, 18/09/1945, 16/10/1945, 17/10/1945, 19/10/1945, 30/10/1945, 28/05/1946, 12/08/1946, 03/09/1946, 04/09/1946, 27/04/1948, 11/08/1948, 31/08/1948, 01/09/1948, 14/09/1948, 12/10/1948, 11/08/1950, 12/08/1950, 23/08/1950, 12/08/1952, 19/05/1954, 30/07/1958, 12/08/1956, 05/08/1958, 08/08/1958, 09/08/1958, 04/08/1960, 05/08/1960, 09/08/1960, 10/08/1960, 11/08/1960, 12/08/1960, 04/08/1960, 05/08/1960, 09/08/1960, 10/08/1960, 11/08/1960, 12/08/1960, 30/08/1961, 10/08/1962, 15/05/1963, 22/03/1964, 08/04/1964 e 10/04/1964.

\section{Diário Carioca}

Edição de 28/06/1945.

Diário de Notícias

Edições de 26/06/1945, 18/09/1945, 19/09/1945, 03/10/1945, 04/10/1945, 16/10/1945, 17/10/1945, 19/10/1945, 20/10/1945, 24/10/1945, 30/10/1945, 24/05/1946, 
28/05/1946, 12/08/1946, 03/09/1946, 04/09/1946, 06/09/1946, 18/04/1948, 27/04/1948, 29/04/1948, 11/08/1948, 31/08/1948, 14/09/1948, 12/10/1948, 11/08/1950, 19/05/1954, 01/07/1956, 12/08/1956, 31/07/1958, 03/08/1958, 05/08/1958, 07/08/1958, 08/08/1958, 10/08/1958, 11/08/1960, 10/08/1962 e 21/03/1964.

Gazeta de Notícias

Edição de 19/10/1945.

\section{Jornal do Comércio}

Edições de 19/09/1945, 26/09/1945, 27/09/1945, 04/10/1945, 17/10/1945, 20/10/1945, 10/11/1945, 29/11/1945, 25-26/04/1949, 01/05/1949, 11/05/1949, 16 17/05/1949, 28/05/1949, 03/06/1949, 06-07/06/1949, 16/06/1949, 19/06/1949, 27 28/06/1949, 01/07/1949, 03/07/1949, 11-12/07/1949, 17/07/1949, 26/07/1949, 31/07/1949, 14/08/1949, 21/08/1949, 22-23/08/1949, 29-30/08/1949, 07/09/1949, 1213/09/1949, 17/09/1949, 25/09/1949, 01/10/1949, 05/10/1949, 15/10/1949, 20/10/1949, 24-25/10/1949, 19/11/1949, 27/11/1949, 06/12/1949, 15/12/1949, 24/12/1949, 0203/01/1950 e 13/01/1950.

\section{O Globo}

Edição de 21/09/1945.

\section{O Jornal}

Edições de 26/06/1945, 28/06/1945, 18/09/1945, 19/09/1945, 16/10/1945, 17/10/1945, 19/10/1945, 20/10/1945, 30/10/1945, 31/10/1945, 04/09/1946, 05/09/1946, 01/09/1948, 12/08/1950, 12/07/1952, 12/08/1952, 19/05/1954, 01/08/1956, 12/08/1956, 05/08/1958, 07/08/1958, 08/08/1958, 09/08/1958, 12/08/1958, 09/08/1960, 30/08/1961 e 15/05/1963.

\section{Tribuna Popular}

Edições de 28/09/1945 e 03/10/1945. 
e.) Legislação

Decreto $\mathrm{n}^{\circ} 19.408$, de 18 de novembro de 1930

Decreto $\mathrm{n}^{\mathrm{o}} 22.478$, de 20 de fevereiro de 1933

Lei $\mathrm{n}^{\circ} 4.215$, de 27 de abril de 1963

f.) Dados estatísticos

Sinopse retrospectiva do ensino no Brasil - 1871/1954. Rio de Janeiro: IBGE, 1956.

Sinopse retrospectiva do ensino no Brasil - 1933/1958. Rio de Janeiro: IBGE, [c. 1958].

g.) Dicionários biográficos

ABREU, Alzira Alves de et alli. (coord.). Dicionário histórico-biográfico brasileiro, pós-1930. Rio de Janeiro: CPDOC/FGV, 2002. (CD-rom).

BARROS, Francisco Reinaldo Amorim de. ABC das Alagoas: dicionário biobibliográfico, histórico e geográfico das Alagoas. Brasília: Senado Federal, 2005.

BEHAR, Eli. Vultos do Brasil: dicionário biográfico brasileiro. São Paulo: Livraria Exposição do Livro, 1967.

BITTENCOURT, Agnello. Dicionário amazonense de biografias. Rio de Janeiro: Conquista, 1973.

BORGES, Ricardo. Vultos notáveis do Pará. Belém: CEJUP, 1986.

CARDOSO, Rejane (coord.). 400 nomes de Natal. Natal: Prefeitura Municipal de Natal, 2000.

CARVALHO, André; BARBOSA, Waldemar. Dicionário biográfico: imprensa mineira. Belo Horizonte: Armazém de Idéias, 1994.

CARVALHO, Antônio Gontijo de. Raul Fernandes, um servidor do Brasil. Rio de Janeiro: Agir, 1956. 
CARVALHO, Carlos Gomes de. Perfis mato-grossenses. Cuiabá: Verdepantanal, 2002.

CASTRO, Oscar Oliveira. Vultos da Paraíba: patronos da academia. [S.1.]: [s.n.], 1955.

COELHO, José Rodrigues Bastos. Coisas e vultos de Aracajú. Rio de Janeiro: [s.n.], 1956.

CORTÉS, C. Homens e instituições no Rio. Rio de Janeiro: IBGE, 1957.

COUTINHO, Afrânio. Brasil e brasileiros de hoje. Rio de Janeiro: SulAmericana, 1961, 2v.

CRESPO, Anésia. Vultos catarinenses. Joinville: Tipografia F. C. Schwartz, [1955].

Dicionário histórico-biográfico do Paraná. Curitiba: Livraria Editora do Chain/ Banco do Estado do Paraná S/A, 1991.

FREITAS, Clodoaldo. Vultos piauienses: apontamentos biográficos. Teresina: Fundação Cultural Monsenhor Chaves, 1998.

GONÇALVES, Wilson Carvalho. Dicionário histórico-biográfico piauiense, 1718-1993. Teresina: [s.n.], 1997.

JOSÉ NETO, Adrião. Dicionário biográfico de escritores piauienses. Teresina: Halley S. A., 1995.

MACHADO, César do Canto. Biografias de catarinenses notáveis. Florianópolis: Insular, 2001.

MARTINS, Mário Ribeiro. Dicionário biobibliográfico de membros da Academia Brasileira de Letras. Goiânia: KELPS, 2007.

MARTINS, Mário Ribeiro. Dicionário biobibliográfico de membros do Instituto Histórico e Geográfico de Goiás. Goiânia: KELPS, 2008.

MEIRINHO, Jali. Nomes que ajudaram a fazer Santa Catarina. Florianópolis: Edeme, [s.d.].

MELO, Luís Correia de. Dicionário de autores paulistas. São Paulo: Comissão do IV Centenário da Cidade de São Paulo, 1954. 
MENDONÇA, Rubens de. Dicionário biográfico mato-grossense. Goiânia: Editora Rio Bonito, 1971.

MONTEIRO, Norma de Góis (coord.). Dicionário biográfico de Minas Gerais. Período republicano 1889/1991. Belo Horizonte: Assembléia Legislativa do Estado de Minas Gerais, 1994. 2v.

NASCIMENTO, Jorge. Perfis maranhenses. São Luís: Fundação Cultural do Maranhão, 1978.

NICOLAS, Maria. Vultos paranaenses. Curitiba: Centro de Letras do Paraná, 1951.

ODILON, Marcus. Pequeno dicionário de fatos e vultos da Paraíba. Rio de Janeiro: Livraria Editora Cátedra, 1984.

OLIVEIRA, João Gualberto de. História dos órgãos de classe dos advogados. São Paulo: [s.n.], 1968.

Quem é quem no Brasil. Biografias contemporâneas. São Paulo: Sociedade Brasileira de Expansão Comercial, 1951.

RICHARD NETO, Gustavo. Homens ilustres de Santa Catarina. Florianópolis: [s.n.], 1959.

SÁ FILHO, Albino. Perfis dos bacharelandos de 1916. Escola Livre de Direito. Rio de Janeiro: Tipografia Faria Moreira, 1919.

SILVA, Raimundo Nonato. Bacharéis de Olinda e Recife. Norte-riograndenses formados de 1832 a 1932. Rio de Janeiro: Pongetti, 1960.

SILVA, Zedar Perfeito da. Perfis de alguns catarinenses ilustres Rio de Janeiro: [s. n.], 1948.

SILVEIRA, Raul. Raul Silveira (depoimento, 1997). Rio de Janeiro, CPDOC/Fundação Escola Nacional de Seguros, 1998, 34 p. dat.

SOUSA, Antônio Loureiro de. Baianos ilustres, 1567-1925. São Paulo: IBRASA/INL, 1979.

\section{3.) Bibliografia geral}


ADORNO, Sergio. Os aprendizes do poder. O bacharelismo liberal na política brasileira. Rio de Janeiro: Paz e Terra, 1988.

ALMEIDA JÚNIOR, Antonio Mendes. Do declínio do Estado Novo ao suicídio de Getúlio Vargas. In: FAUSTO, Boris (direção). História Geral da Civilização Brasileira. São Paulo: Difel, 1981, tomo 3, volume 3.

ALMEIDA, Cristiane Rodrigues Soares. O Governo João Goulart nas páginas da Folha de S. Paulo. Uberlândia, 2008. Dissertação (Mestrado em História). Universidade Federal de Uberlândia.

BANDEIRA, Moniz. Presença dos Estados Unidos no Brasil. Rio de Janeiro: Civilização Brasileira, 1973.

BASBAUM, Leôncio. História sincera da República. De 1930 a 1960. São Paulo: Editora Edaglit, 1962, v. 3.

BASTOS, Aurélio Wander (coord.). Os cursos jurídicos e as elites políticas brasileiras. Brasília: Câmara dos Deputados, 1978.

BASTOS, Aurélio Wander. A Ordem dos Advogados e o Estado democrático no Brasil. Rio de Janeiro, 2007. Tese (Doutorado em Ciência Política). IUPERJ.

BENEVIDES, Maria Victoria de Mesquita. A UDN e o udenismo. Ambigüidades do liberalismo brasileiro (1945 - 1965). Rio de Janeiro: Paz e Terra, 1981.

BENEVIDES, Maria Victoria de Mesquita. O governo Jânio Quadros. São Paulo: Brasiliense, 1993.

BONELLI, Maria da Gloria. Profissionalismo e política no mundo do direito: as relações dos advogados, desembargadores, procuradores de justiça e delegados de polícia com o Estado. São Carlos: EdUFSCar/Editora Sumaré, 2002.

BUONICORE, Augusto César. Os comunistas e a estrutura sindical corporativa (1948-1952). Campinas, 1996. Dissertação (Mestrado em Ciência Política). UNICAMP.

CAPELATO, Maria Helena. O Estado Novo: o que trouxe de novo? In: FERREIRA, Jorge; DELGADO, Lucilia de Almeida Neves (org.). O tempo do nacional-estatismo: do início da década de 1930 ao apogeu do Estado Novo. Rio de Janeiro: Civilização Brasileira, 2003. 
CARONE, Edgard. A República liberal. Evolução política (1945-1964). Rio de Janeiro: Difel, 1985.

CARONE, Edgard. O Estado Novo (1937-1945). Rio de Janeiro: Difel, 1977.

CARVALHO, José Murilo de. A construção da ordem: a elite política imperial. Teatro de sombras: a política imperial. Rio de Janeiro: Civilização Brasileira, 2003.

CERVO, Amado Luiz; BUENO, Clodoaldo. História da política exterior do Brasil. Brasília: Editora Universidade de Brasília, 2008.

COELHO, Edmundo Campos. As profissões liberais. Medicina, engenharia e advocacia no Rio de Janeiro: 1822-1930. Rio de Janeiro: Record, 1999.

COELHO, Fernando. A OAB e o regime militar (1964-1986). Recife: OAB Seção Pernambuco, 1996.

Conselho Federal da OAB. Ensino jurídico OAB: 170 anos de cursos jurídicos no Brasil. Brasília: Conselho Federal da OAB, 1997.

CORRÊA, Larissa Rosa. Trabalhadores têxteis e metalúrgicos a caminho da Justiça do Trabalho: leis e direitos na cidade de São Paulo - 1953 a 1964. Campinas, 2007. Dissertação (Mestrado em História). UNICAMP.

COSTA, Emília Viotti da. O Supremo Tribunal Federal e a construção da cidadania. São Paulo: Editora UNESP, 2006.

COUTINHO, Carlos Nelson. As categorias de Gramsci e a realidade brasileira. In: COUTINHO, Carlos Nelson; NOGUEIRA, Marco Aurélio. Gramsci e a América Latina. Rio de Janeiro: Paz e Terra, 1988.

COUTINHO, Carlos Nelson. Gramsci. Porto Alegre: L\&PM, 1981.

D’ARAÚJO, Maria Celina. O Segundo Governo Vargas, 1951-1954. Democracia, partidos e crise política. Rio de Janeiro: Zahar Editores, 1982.

DORS, Marines. Dyonélio Machado (1895-1985): os múltiplos fios da trajetória ambivalente de um intelectual. São Leopoldo, 2008. Dissertação (Mestrado em História). UNISINOS.

DREIFUSS, René Armand. 1964: a conquista do Estado. Petrópolis: Vozes, 1981. 
DULLES, John W. F. Sobral Pinto: a consciência do Brasil. Rio de Janeiro: Nova Fronteira, 2001.

FAGUNDES, Laura. Instituto dos Advogados Brasileiros: 150 anos de história, 1843-1993. Rio de Janeiro: IAB/Destaque, 1995.

FALCÃO, Joaquim. Os advogados: ensino jurídico e mercado de trabalho. Recife: Fundação Joaquim Nabuco/Editora Massangana, 1984.

FAUSTO, Boris. A revolução de 1930: historiografia e história. São Paulo: Companhia das Letras, 1997.

FERREIRA, Jorge. A democratização de 1945 e o movimento queremista. In: FERREIRA, Jorge; DELGADO, Lucilia de Almeida Neves (org.). O tempo da experiência democrática: da democratização de 1945 ao golpe civil-militar de 1964. Rio de Janeiro: Civilização Brasileira, 2003.

FICO, Carlos. Além do golpe: a tomada do poder em 31 de março de 1964 e a ditadura militar. Rio de Janeiro: Record, 2004.

FRENCH, John. Afogados em leis. A CLT e a cultura política dos trabalhadores brasileiros. São Paulo: Editora Fundação Perseu Abramo, 2001.

GASPARI, Elio. A ditadura envergonhada. São Paulo: Companhia das Letras, 2002.

GOMES, Angela Maria de Castro. A invenção do trabalhismo. Rio de Janeiro: Relume Dumará, 1994.

GOMES, Angela Maria de Castro. O populismo e as ciências sociais no Brasil: notas sobre a trajetória de um conceito. In: FERREIRA, Jorge (org.). O populismo e sua história: debate e crítica. Rio de Janeiro: Civilização Brasileira, 2001.

GOMES, Angela Maria de Castro; FERREIRA, Jorge. Jango: as múltiplas faces. Rio de Janeiro: Editora FGV, 2007.

GRAMSCI, Antonio. Cadernos do cárcere. Maquiavel. Notas sobre o Estado e a política. Rio de Janeiro: Civilização Brasileira, 2000, v. 3.

GUEIROS, Nehemias. A advocacia e o seu estatuto. Rio de Janeiro: Livraria Freitas Bastos, 1964. 
GUIMARÃES, Lúcia Maria Paschoal; BESSONE, Tânia. História da Ordem dos Advogados do Brasil. Criação, primeiros percursos e desafios (1930-1945). Brasília: OAB, 2003, v. 4.

GUIMARÃES, Lúcia Maria Paschoal; BESSONE, Tânia; MOTTA Marly Silva da. História da Ordem dos Advogados do Brasil. O IAOB na Primeira República. Brasília: OAB, 2003, v. 3.

HIPPOLITO, Lucia. De raposas e reformistas: o PSD e a experiência democrática brasileira, 1945-64. Rio de Janeiro: Paz e Terra, 1985.

IANNI, Octavio. O colapso do populismo no Brasil. Rio de Janeiro: Civilização Brasileira, 1968.

LESSA, Renato; LINHARES, Leila. Consenso e identidade: os advogados e a sua ordem. Rio de Janeiro: OAB - Rio de Janeiro, 1991.

LIMA JR., Olavo Brasil de; KLEIN, Lúcia Maria Gomes; MARTINS, Antônio Soares. O advogado e o Estado no Brasil. Rio de Janeiro: Edições Dados, 1970.

LOVE, Joseph L. O regionalismo gaúcho e as origens da Revolução de 1930. São Paulo: Perspectiva, 1975.

MATTOS, Marco Aurélio Vannucchi Leme de; SWENSSON JÚNIOR, Walter Cruz. Contra os inimigos da ordem: a repressão política da ditadura militar (19641985). Rio de Janeiro: DP\&A, 2003.

MICELI, Sergio. Carne e osso da elite política brasileira pós-1930. In: FAUSTO, Boris (direção). História Geral da Civilização Brasileira. Rio de Janeiro: Bertrand Brasil, 1996, tomo 3, volume 3.

MICELI, Sergio. Intelectuais à brasileira. São Paulo: Companhia das Letras, 2001 .

MOREL, Edmar. Histórias de um repórter. Rio de Janeiro: Record, 1999.

MOTTA, Marly Silva da (org.). A OAB na voz de seus presidentes. Brasília: OAB, 2003, v. 7.

MOTTA, Marly Silva da. A Ordem dos Advogados do Brasil: entre a corporação e a instituição. Disponível em www.cpdoc.fgv.br 
MOTTA, Marly Silva da; DANTAS, André Vianna. História da Ordem dos Advogados do Brasil: da redemocratização ao Estado democrático de direito (19461988). Rio de Janeiro: OAB, 2006, v. 5.

MOTTA, Rodrigo Patto Sá. Em guarda contra o perigo vermelho: anticomunismo no Brasil (1917-1964). São Paulo: Perspectiva/FAPESP, 2002.

MOURA, Gerson. Sucessos e ilusões: relações internacionais do Brasil durante e após a Segundo Guerra Mundial. Rio de Janeiro: Editora da Fundação Getúlio Vargas, 1991.

NABUCO, Joaquim. Um estadista do Império. São Paulo: Instituto Progresso Editorial, 1949, v.1.

PANDOLFI, Dulce Chaves. A construção da democracia no Brasil: avanços e retrocessos. Ciências Sociais Hoje, São Paulo, p. 158-184, 1989.

PENA, Eduardo Spiller. Pajens da casa imperial: jurisconsultos e escravidão no Brasil do século XIX. Campinas, 1998. Tese (Doutorado em História). UNICAMP.

PINHEIRO, Paulo Sérgio. Classes médias urbanas: formação, natureza, intervenção na vida política. In: FAUSTO, Boris (direção). História Geral da Civilização Brasileira. Rio de Janeiro: Bertrand Brasil, 1997, tomo 3, volume 2.

PORTELLI, Hugues. Gramsci et le bloc historique. Paris: PUF, 1972.

RAMÍREZ, Hernán Ramiro. Os institutos de estudos econômicos de organizações empresariais e sua relação com o Estado em perspectiva comparada: Argentina e Brasil, 1961-1996. Porto Alegre, 2005. Tese (Doutorado em História). UFRS.

REIS FILHO, Daniel Aarão. O colapso do colapso do populismo ou a propósito de uma herança maldita. In: FERREIRA, Jorge (org.). O populismo e sua história: debate e crítica. Rio de Janeiro: Civilização Brasileira, 2001.

RICUPERO, Bernardo; FERREIRA, Gabriela Nunes. Estado e sociedade em Oliveira Vianna e Raymundo Faoro. Caderno CRH, Salvador, v. 18, n 44, p. 223-227, maio/agosto 2005.

ROLLEMBERG, Denise. Memória, opinião e cultura política. A Ordem dos Advogados do Brasil sob a Ditadura (1964-1974). In: REIS, Daniel Aarão; ROLLAND, 
Denis. (org.). Modernidades alternativas. Rio de Janeiro: Editora da Fundação Getúlio Vargas, 2008.

SAES, Décio. Classe média e política no Brasil, 1930-1964. In: FAUSTO, Boris (direção). História Geral da Civilização Brasileira. Rio de Janeiro: Bertrand Brasil, 1996, tomo 3, volume 3.

SAES, Décio. Classe média e políticas de classe (uma nota teórica). Contraponto, Rio de Janeiro, número 2, ano 2, p. 96-102, novembro de 1977.

SILVA, Evandro Lins e. O salão dos passos perdidos: depoimento ao CPDOC. Rio de Janeiro: Nova Fronteira/ Editora da Fundação Getúlio Vargas, 1997.

SIMÕES, Teotônio. Os bacharéis na política. A política dos bacharéis. São Paulo, 1983. Tese (Doutoramento em Ciência Política). USP.

SIQUEIRA, Marcello Rodrigues. A lei e a ordem: a formação da $O A B$ e a resistência ao golpe de 64 em Goiás. Goiás, 2003. Dissertação (Mestrado em História). Universidade Federal da Goiás.

SKIDMORE, Thomas. Brasil: de Castelo a Tancredo. Rio de Janeiro: Paz e Terra, 1988.

SKIDMORE, Thomas. Brasil: de Getúlio a Castelo. Rio de Janeiro: Paz e Terra, 1982.

SOARES, Gláucio Ary Dillon. Sociedade e política no Brasil. São Paulo: Difusão Européia do Livro, 1973.

SODRÉ, Ruy de Azevedo. Advogado: a regulamentação e a ética profissional. São Paulo: Revista dos Tribunais, 1963.

SWENSSON JÚNIOR, Walter Cruz. Os limites da liberdade: a atuação do Supremo Tribunal Federal no julgamento de crimes políticos durante o regime militar de 1964 (1964-1979). São Paulo, 2007. Tese (Doutorado em História). USP.

TOLEDO, Caio Navarro de. 1964: o golpe contra as reformas e a democracia. Revista Brasileira de História, São Paulo, volume 24, número 47, 2004, p. 13-28.

TOLEDO, Caio Navarro de. O governo Goulart e o golpe de 64. São Paulo: Brasiliense, 2004. 
VALE, Osvaldo Trigueiro do. O general Dutra e a redemocratização de 45. Rio de Janeiro: Civilização Brasileira, 1978.

VENÂNCIO FILHO, Alberto. Das arcadas ao bacharelismo. 150 anos de ensino jurídico no Brasil. São Paulo: Perspectiva, 1977.

VENÂNCIO FILHO, Alberto. Notícia histórica da OAB, 1930-1980. São Paulo: Conselho Federal da OAB, 1982.

VIANNA, Luiz Werneck. Caminhos e descaminhos da revolução passiva à brasileira. In: VIANNA, Luiz Werneck. A revolução passiva. Iberismo e americanismo no Brasil. Rio de Janeiro: Revan, 2004.

VIANNA, Luiz Werneck. Os intelectuais da tradição e a modernidade: os juristas-políticos da OAB. In: Travessia: da Abertura à Constituinte. Rio de Janeiro: Livraria Taurus Editora, 1986.

VIANNA, Luiz Werneck; VIANNA, Maria Lucia Teixeira Werneck. $A O A B$ como intelectual coletivo: 1964-1980. Rio de Janeiro: IUPERJ, 1984. 2v. (datilogr.).

WEFFORT, Francisco. O populismo na política brasileira. Rio de Janeiro: Paz e Terra, 1978.

\section{4.) Sites}

http://www.direitouerj.org.br

http://www.iabnacional.org.br

http://www.ibge.gov.br

http://www.oab-rj.org.br/

http://www2.camara.gov.br

www.adesg.org.br

www.cpdoc.fgv.br

www.vermelho.org.br 


\section{Apêndice A: Diretorias do Conselho Federal (1933-1967)}

\section{Presidentes}

1933-1938: Levi Carneiro

1938-1944: Fernando de Melo Viana

1944-1948: Raul Fernandes ${ }^{667}$

1948: Augusto Pinto Lima

1948-1950: Odilon Barrot Martins de Andrade

1950-1952: Haroldo Valadão

1952-1954: Atílio Vivacqua

1954-1956: Miguel Seabra Fagundes

1956-1958: Nehemias Gueiros

1958-1960: Alcino de Paula Salazar

1960-1962: José Eduardo do Prado Kelly

1962-1965: Carlos Povina Cavalcanti

1965: Temístocles Marcondes Ferreira

1965-1967: Alberto Barreto de Melo

\section{Vice-presidente}

1963-1965: Temístocles Marcondes Ferreira

1965-1967: Luís Lira

\section{Secretários-gerais}

1933-1944: Atílio Vivacqua

1944-1946: Osvaldo Trigueiro de Albuquerque Melo

1947-1948: João Nicolau Máder Gonçalves

1948-1950: José Joaquim Marques Filho

1950-1952: Macário de Lemos Picanço

\footnotetext{
${ }^{667}$ Com muita freqüência, Augusto Pinto Lima assumiu a presidência do Conselho Federal na gestão Raul Fernandes.
} 
1952-1965: Alberto Barreto de Melo

Fontes: Atas do Conselho Federal da OAB, 1945-1964; VENÂNCIO FILHO, Alberto. Notícia histórica da OAB, 1930-1980. São Paulo: Conselho Federal da OAB, 1982. 


\section{Apêndice B: Integrantes do Conselho Federal da OAB (1945-1964) ${ }^{668}$}

Abelardo da Assunção Rupp

Adauto Lúcio Cardoso

Áderson Horn Ferro

Adroaldo Mesquita da Costa

Afonso Augusto Moreira Pena Júnior

Afonso Guilhermino Wanderlei Júnior

Afrânio Salgado Lages

Agenor Teixeira de Magalhães

Aguinaldo Figueiredo

Alberto Americano

$\underline{\text { Alberto Barreto de Melo }}$

Alberto Francisco Torres

Alberto Monteiro da Silva

Alceu Mário de Sá Freire

Alci Amorim da Cruz

Alci Demillicamps

Alcides Machado Gonçalves

$\underline{\text { Alcino de Paula Salazar }}$

$\underline{\text { Aldo Prado }}$

Alfio Ponzi

Alfredo Baltazar da Silveira

Alfredo Ewbank da Rocha Leão

Alfredo Tomé Torres

$\underline{\text { Aliomar de Andrade Baleeiro }}$

Altino Morais

$\underline{\text { Álvaro Botelho Maia }}$

${ }^{668}$ Estão sublinhados os nomes dos 179 conselheiros dos quais obtive informações biográficas. 
Álvaro Burgos Carneiro de Campos

Álvaro Castelo

Álvaro Duncam Ferreira Pinto

Amarílio Novis

André de Faria Pereira

Anor Butler Maciel

Antônio Carvalho Guimarães

Antônio Chalbaud Biscaia

Antônio Cláudio Fernandes Rocha

Antônio de Figueiredo Murta

Antônio Gonçalves de Oliveira

Antônio Manuel Carvalho Neto

Antonio Martins do Rego

Antônio Paulo Soares de Pinho

Anuar Farah

Arino de Sousa Mattos

Ariosto de Resende Rocha

Aristeu Borges de Aguiar

Arnoldo Medeiros da Fonseca

Artur da Rocha Ribeiro

$\underline{\text { Artur Ferreira da Costa }}$

Artur Pena Filho

$\underline{\text { Artur Porto Pires }}$

Artur Possolo

Atílio Vivacqua

Augusto Carneiro de Albuquerque

Augusto Pinto Lima

Aureliano Leite

Bartolomeu Anacleto 
Benedito Martins Napoleão Rego

Braz Felício Panza

Cândido Luís Maria de Oliveira Neto

Carlos Alberto Dunshee de Abranches

Carlos Bernardino de Aragão Bozano

Carlos da Rocha Guimarães

Carlos de Araújo Lima

Carlos de Morais Andrade

Carlos Maurício Martins Rodrigues

Carlos Medeiros da Silva

Carlos Povina Cavalcanti

Cehyl Tinoco

César Vale Damasceno Ferreira

Cícero Aranha

Claribalte Vilaim Vasconcelos Galvão

Claro Augusto de Godoi

Clóvis Ferro Costa

Clóvis Paulo da Rocha

Clóvis Ramalhete Maia

Clóvis Rodrigues

Corinto de Arruda Falcão

Cristino Castelo Branco

Dâmaso Rocha

Daniel Serapião de Carvalho

Dario Délio Cardoso

Dario Paulo de Almeida Magalhães

Davi Alves de Melo

Décio Bastos Coimbra

Demóstenes Madureira de Pinho 
Dídimo de Morais

Dionísio Silveira

Djalma Aranha Marinho

Djalma Tavares da Cunha Melo

Domingos Cavalcanti de Sousa Leão Júnior

Edgar de Toledo

Edgar Queiroz do Vale

Edmundo da Luz Pinto

Edmundo Lins Neto

Edmundo Teles da Rocha

Edson de Oliveira Ribeiro

Elizabeto Barbosa de Carvalho

Ernani Lins da Cunha

Ernesto Pereira Borges

Eurico de Aguiar Sales

Eurico de Albuquerque Raja Gabaglia

Evandro Cavalcanti Lins e Silva

Evandro Gueiros Leite

Fenelon Nonato da Silva

Fernando Carneiro da Cunha Nóbrega

Firmino Ferreira da Paz

Francisco de Paula Leite e Oiticica Filho

Francisco Elias da Rosa Oiticica

Francisco Elídio Lenoir de Merocourt

Francisco Gonçalvez

Francisco Martins de Almeida

Francisco Pereira da Silva

Frederico Zacharias Nunam

Galeno Veríssimo da Fonseca 
Gaston Luís do Rego

Gil Soares de Araújo

Gilberto Valente

$\underline{\text { Hamilton Prisco Paraiso }}$

Hamilton Xavier

Hariberto de Miranda Jordão

Haroldo Valadão

Hebel Quintela

$\underline{\text { Heráclito da Fontoura Sobral Pinto }}$

Hermes Pereira de Sousa

Hiati Leal

Hirosê Ferreira Pimpão

$\underline{\text { Hugo Dunshee de Abranches }}$

Humberto de Sousa Quartim Pinto

Itagildo Ferreira

Ivan Paixão França

Ivens Bastos de Araújo

Jacinto Aben Athar Neto

Jaime Baleeiro

Jair Tovar

Jessé Cláudio Fontes de Alencar

João Batista Bonassis

$\underline{\text { João de Oliveira Filho }}$

João Manoel de Carvalho Santos

João Medeiros Filho

João Nicolau Máder Gonçalves

João Otaviano de Lima Pereira

João Rocha Moreira

$\underline{\text { João Soares Palmeira }}$ 
$\underline{\text { João Vilasboas }}$

Joaquim Amazonas

Joaquim Augusto Perilo

Joaquim Gomes de Almeida

Joaquim Gomes de Norões e Sousa

Joaquim Guedes Correia Godin Neto

Joaquim José Fernandes Couto

Joaquim Murilo Silveira

Joaquim Nunes Tassára

Jorge Botelho

Jorge Dyott Fontenelle

Jorge Fernando Loretti

Jorge Lafayette Pinto Guimarães

José Adriano Marrey Júnior

José Augusto Bezerra de Medeiros

José Burlamaqui Auto de Abreu

José de Carvalho Leomil

José de Castro Azevedo

José de Pontes Vieira

José Eduardo do Prado Kelly

José Emídio de Oliveira

José Ferreira de Souza

José Jaime Ferreira de Vasconcellos

José Joaquim Marques Filho

José Luís Salles

$\underline{\text { José Marcelo Moreira }}$

José Maria MacDowell da Costa

José Mário Porto

José Martins Rodrigues 
$\underline{\text { José Mota Maia }}$

José Néder

José Rocha Leal

José Rodrigues Batalha de Matos

José Tavares da Cunha Melo

José Telles da Cruz

José Vieira Coelho

Justo Rangel Mendes de Morais

Laudo de Almeida Camargo

Lauro Benito Alonso

Lauro Sodré Lopes

Leopoldo Cesar de Miranda Lima Filho

Leopoldo Tavares da Cunha Melo

Letácio Jansen

Lourival Oberlander

Lúcio Resende

Luís Dias Rollemberg

Luís Galotti

Luís Lopes de Souza

Luís Machado Guimarães

Luís Mendes de Morais Neto

Luís Raimundo de Lira Tavares

Macário de Lemos Picanço

Mair Cerqueira

Manuel José Machado Barbuda

Manuel Soares de Castro

Marcos Botelho

$\underline{\text { Maria Rita Soares de Andrade }}$

Mário Bezerra de Brito Pereira 
Mario Brasil de Araújo

Mario Carvalho de Vasconcellos

Mário de Alencastro

Maurício de Medeiros Furtado

Maurilio Curado Fleury

Max José da Costa Santos

Melquisedec Figueiredo Monte

Miguel Seabra Fagundes

Milton Campos

Moacir Dantas Cavalcanti

Múcio Teixeira

$\underline{\text { Nehemias Gueiros }}$

Nélio Pontes dos Reis

Nelson de Souza Carneiro

Nelson Joaquim da Silva

Nicanor Faria e Silva

Nicolau Glavan de Oliveira

Odilon Barrot Martins de Andrade

Odir Braga Land

Olímpio de Carvalho

Oscar Correia Pina

Oscar José Muller

Oscar Stevenson

Osvaldo de Souza Vale

Osvaldo Fernandes Vergara

Osvaldo Murgel de Rezende

Osvaldo Trigueiro de Albuquerque Melo

Otávio de Mendonça

Otávio Moreira Dias 
Otelo Sarmento Serra Lima

Oto de Andrade Gil

Paulo Barreto de Araújo

Paulo de Salvo Sousa

$\underline{\text { Paulo Fleury da Silva de Sousa }}$

Paulo Francisco Póvoa

Paulo Malta Ferraz

Paulo Martins de Sousa Ramos

Paulo Pimentel Belo

Paulo Pinto Neri

Paulo Sérgio Saldanha Marinho

Paulo Whitaker

Pedrílvio Ferreira Guimarães

Pedro Fraga

$\underline{\text { Pedro Leão Fernandes Espinosa Vergara }}$

Plínio Francisco dos Santos

Plínio Pinheiro Guimarães

$\underline{\text { Poti Medeiros }}$

Raimundo Gomes Nogueira

$\underline{\text { Raimundo Públio Bandeira de Melo }}$

Ramon Alonso

$\underline{\text { Raul da Cunha Ribeiro }}$

$\underline{\text { Raul de Sousa Silveira }}$

$\underline{\text { Raul Fernandes }}$

$\underline{\text { Renato Cantidiano Vieira Ribeiro }}$

$\underline{\text { Rodrigo Otávio de Langgard Meneses Filho }}$

Romualdo Crepory Franco

Rovane Tavares Guimarães

$\underline{\text { Rui Araújo }}$ 
Samuel Vital Duarte

$\underline{\text { Sanelva de Rohan Araújo Soares }}$

Saturnino Cardoso de Castro

$\underline{\text { Scila Sousa Ribeiro }}$

Sérgio Otaviano de Almeida

Silvio da Cunha Santos

$\underline{\text { Targino Ribeiro }}$

Temístocles Brandão Cavalcanti

Temístocles Marcondes Ferreira

Teófilo de Azeredo Santos

Teotônio Maurício Monteiro de Barros Filho

Tércio César de Queiróz

$\underline{\text { Tertuliano de Menezes Mitchel }}$

Tomé Tostes Machado

Ubaldo Ramalhete Maia

Ulisses Silveira Guimarães

Vilmar Orlando Dias

Walter Menezes Vieiralves

Washington de Almeida

Wilson Cavalcante de Farias

Wilson do Egito Coelho

Wilson Regalado Costa

Fonte: Atas do Conselho Federal da OAB, 1945-1964. 